\title{
WestVirginiaUniversity
}

THE RESEARCH REPOSITORY @ WVU

Graduate Theses, Dissertations, and Problem Reports

2006

\section{Left arm of the Republic: The Department of the Pacific during the Civil War}

James Robbins Jewell

West Virginia University

Follow this and additional works at: https://researchrepository.wvu.edu/etd

\section{Recommended Citation}

Jewell, James Robbins, "Left arm of the Republic: The Department of the Pacific during the Civil War" (2006). Graduate Theses, Dissertations, and Problem Reports. 2505.

https://researchrepository.wvu.edu/etd/2505

This Dissertation is protected by copyright and/or related rights. It has been brought to you by the The Research Repository @ WVU with permission from the rights-holder(s). You are free to use this Dissertation in any way that is permitted by the copyright and related rights legislation that applies to your use. For other uses you must obtain permission from the rights-holder(s) directly, unless additional rights are indicated by a Creative Commons license in the record and/ or on the work itself. This Dissertation has been accepted for inclusion in WVU Graduate Theses, Dissertations, and Problem Reports collection by an authorized administrator of The Research Repository @ WVU.

For more information, please contact researchrepository@mail.wvu.edu. 


\title{
LEFT ARM OF THE REPUBLIC: \\ THE DEPARTMENT OF THE PACIFIC DURING THE CIVIL WAR
}

JAMES ROBBINS JEWELL

A dissertation submitted to the Eberly College of Arts and Sciences at West Virginia University in partial fulfillment of the requirements for the degree of

\author{
Doctor of Philosophy \\ in \\ History \\ Department of History \\ Morgantown, West Virginia \\ 2006 \\ Ken Fones-Wolf, Ph.D., Chair \\ Robert Carriker, Ph.D. \\ Jack Hammersmith, Ph.D. \\ John Super, Ph.D. \\ Steve Zdatny, Ph.D.
}

Key words: Civil War, West, California, Oregon, Native Americans, George Wright

Copyright James Robbins Jewell 


\title{
ABSTRACT \\ LEFT ARM OF THE REPUBLIC: THE DEPARTMENT OF THE PACIFIC DURING THE CIVIL WAR
}

\author{
JAMES ROBBINS JEWELL
}

\begin{abstract}
Although the Civil War was fought largely in the East it was a transcontinental war. Securing the Far West for the Union played an important, though secondary role in the northern war effort. When most of the Regular Army units were called east, holding the region and confronting the multiple threats to its security fell to the western volunteers. Through their efforts, they maintained a general stability in a vast region where both potential and actualized threats could easily have hampered Union efforts in the main theatres of war. Therefore, by quelling secessionist schemes and activities and attempting to maintain peaceful relations between the various tribes and the flood of whites that continued to flow into the region, the less than 20,000 volunteers protected the Far West from internal dangers.

Internal responsibilities were only part of the potential hazards lurking along and within the department's vast territory. As had been demonstrated during the 1859 Pig War crisis, relations with the British in far western Canada could easily turn dangerous. Likewise, once the French imperial designs for Mexico were put into action, department commanders had to ensure that the United States did not become entangled in that quagmire, despite the sympathies of most Americans for the Mexican cause. Thus, despite having been ignored and misunderstood, the Department of the Pacific played an important role in the larger national scene. Had not the department carried out its responsibilities successfully, the nature of the Civil War or the development of the Far West (or both) could have gone differently. To better understand the contributions made to Union war effort, his study is an examination of the responsibilities faced by the Union's most remote military command during the Civil War and how it met those responsibilities, and in turn how doing so aided the Union cause by protecting the Far West from the nation's enemies.
\end{abstract}




\section{ACKNOWLEDGEMENT}

On more than one occasion, when thinking about the acknowledgement section of this dissertation I have promised to begin with this statement: "I wish to thank the person who has done the most to make this dissertation possible, the one who has put in the most hours, suffered the longest, gone without sleep too often to recall, given the most sweat that would be ME!” Of course, as anyone who has undertaken a scholarly study knows, dissertations, theses, and books are collaborative efforts, where each part makes the whole possible. Therefore, it is with great pleasure that I take a few paragraphs to acknowledge most, but probably not all, the persons who helped me as I worked on not only my dissertation, but my doctorate as well.

First and foremost, I would like to thank my committee for their comments and suggestions during the interrogation experience, known as the dissertation defense. Naturally, the chair, Dr. Ken Fones-Wolf, was by far the most integral part of the committee, and for that alone I owe him my thanks. However, I am indebted to him for far more than his service as chair. Having more or less inherited me, a fate for which I am eternally grateful, he did an excellent job of keeping me focused while at the same time making sure the process remained manageable. Knowing my own strengths and weaknesses, I fully understand how challenging it must have been at times working with someone more or less temperamentally his opposite. There is no doubt that I benefited a great deal from his calm, easy going demeanor, which did much to keep my Type A, sometimes over the top tendencies in check. The next round is on me. 
If the dissertation committee tends to get most of the recognition for shepparding a candidate through the dissertation process, it is at the expense of an equally important group of people. To say that this dissertation would not have been completed without the tremendous assistance of the inter library loan departments at West Virginia University and Bloomsburg University is an understatement. When writing about the West Coast while living on the East Coast, one is wholly reliant upon the astounding abilities routinely displayed by the ILL staff. On behalf of all the librarians and their staffs that helped me during the seemingly endless research that was conducted, I would like to single out and offer my deepest gratitude to Judy McCracken (WVU) and Ann Diseroad (BU). You and your staffs were awe-inspiring, and should give lessons to other libraries about how ILL should work.

With research pouring in it soon came time to write the thing. As someone who takes pleasure from both research and writing, I was fortunate that I thoroughly enjoyed living with this topic for these past years. None the less, there were many days I felt I could not see the final page ever being on the horizon. When those days came, I was fortunate to have other academics to encourage, cajole, and badger me to stick with it. For constantly repeating a mantra which I cannot print here, I would like to thank my friend Dr. Charlie Mutschler (University Archivist, Eastern Washington University), and my mentor and friend Dr. Dick Donley (Professor Emeritus, EWU). The many telephone calls to each of them over these years were as good for the spirit as they were insightful about the process. For all of his assistance impersonating me to keep me registered at WVU and for the leg work he did in Morgantown on my behalf, I would be remiss if I 
did not thank Jim DePalma, who is currently keeping my old office warm at WVU. May the Serbs be as good to you as the Department of the Pacific was to me.

In my two years as a visiting instructor at Bloomsburg University, I received valuable assistance from two unlikely sources. I am deeply indebted to Dr. Rick Sauers for opening his unpublished index to the National Tribune which led to a number of primary sources that I would otherwise not have found. In the larger sense, I greatly appreciate the generosity he showed me during my stay in his state. I hope I will be in a similar position to return the favor to some young scholar in the future. I also need to thank another Pennsylvania; Karla Procopio’s sharp editorial eye and insightful, often sarcastic, comments improved those early chapters, and for that I thank her.

By far the greatest professional assistance I received during the entire writing process came from my best friend Dr. Eugene Van Sickle. Not only did he conduct some of the research for me, making copies of articles from the San Francisco Daily Alta California, he also read portions of this dissertation when it was in its rawest state, and, like Jim DePalma, he did some of the administrative leg-work for me after I moved to Idaho. For all of that I remain grateful. However, I owe him far more than that; for helping me drive my family’s entire possessions back across country, encouraging me along the writing trail, not taunting me when he lapped me and finished his own doctorate, and most of all, for his brotherhood, I thank and respect him. I went to West Virginia to earn a doctorate, which I now have done, and I gained a brother in the process.

While my academic colleagues and friends helped me survive the actual doing of the dissertation, it was, and is, my family that has kept me afloat throughout these long 
years spent in pursuit of a Ph.D. It is difficult to know how to thank one's family because being there and being supportive is what families do, at least mine, which includes my parents as well as my wife Elizabeth's family. For all the support, both emotional and on occasion monetary (when it came time to fly back and forth across the continent for holidays) that they have provided not just me, but all of us -Elizabeth, Jacob, Cullen, and I -I have a debt which I can never truly repay our families, both the Jewells and the Traynors. My parents, in particular, have listened to endless chapter ideas and then read the rough drafts of most of those chapters, whether they wanted to or not. I especially thank my dad for fielding all manner of questions relating to western geography and history about all the western and southwestern places where he lived in the past. My grandparents may have moved like the proverbial gypsies when he was a kid, but that experience served me well when I had questions. Whereas my dad got the questions, my mother endured my stress about the process as it oozed through the telephone lines, all the while remaining an ardent cheerleader, convinced of my ultimate success -more so than I was at times. Thanks Mom.

After so many years I have come to regard writing this dissertation not merely as an endurance contest, but as an academic Iron Man, both brutal and long. Looking back, long does not begin to describe how it has felt. Having graduated from high school in 1987, I have spent all but two years since in pursuit of this doctorate. Along the way I have been side-tracked, spending 13 years in the hotel industry, almost gave the whole thing up more than once, married, and brought two sons into this world. There is no doubt that I would not have made it without the aid, teamwork, support, encouragement, friendship, and love of my wife Elizabeth. She never even blinked when we moved 
across the country, twice, went from West Virginia to Pennsylvania, and she is as ready for the next stop today as she was in 1997 when I was accepted into the doctoral program at WVU. It has been a challenge these last eight years, and there have been difficult days, but Elizabeth and our boys make every one of them worth the struggle, academic and otherwise. To her, most of all, I owe the greatest debt of gratitude; for all that she does, including shouldering the bulk of the parenting for long stretches at a time when I have raced to finish one chapter, so I can go onto the next. As for our handsome sons, so full of energy and high spirits, so much fun to be with, they have kept me grounded (changing diapers will do that) in what is really important, and I am a better person for it. I hope as they grow older they will be proud of both their parents and understand why it was that we moved often in the early years, and why dad was at his office for so many nights. Thank you Jacob (who acts like me) and Cullen (who looks like me) for making your mom’s and my life so incredible.

I wish I could end on a high note, but alas, I want to conclude by thanking those persons who will never read these lines, but who have meant so much to me, who have influenced who I am, and made me a better person for their presence in my life, both as a scholar and as a person. Earning a doctorate takes time, and in my case, a whole lot of time. Unfortunately, the passage of time is accompanied by the passing of people. I am saddened that four people who influenced my decision to go into academics and who celebrated my progress are not here to see the successful conclusion of my efforts. My grandparents, George and Margaret Robbins and Fred Jewell essentially turned me into an historian from a young age by supplying me with a substantial library of history books. Since each enjoyed a very long life, they themselves were history (how many 
people can say that someone sang them a song he had learned from a Civil War veteran, who learned it from the slaves during the war). I miss them all every day, and wish they had lived to see me finish.

A week prior to defending my dissertation Dr. John Traynor, my father-in-law, finally succumbed to the brain cancer that stole him from us even before he passed away. That was a weighty thing to have on my mind when I was going through the defense. Two days after successfully defending my dissertation his funeral was held. At the reception that followed a few people approached me to offer congratulations for surviving the defense. When they did, all I could think was that the one person who would have been the most excited for me was the man all those hundreds of people were there to honor. I can hear his voice, hearty and deep, extolling my achievement, one my mother-in-law prodded him through not so many years earlier, almost as if he were there. Our personalities did not always mesh (his ebullient, mine more realistic), but I know he was happy for me, and proud, and for that I thank him. "Oh Canada, we stand on guard for thee."

To each and every person, some of whom I am sure I have forgotten to mention, thank you. Now let's see what mischief I can get into next.

-Couer d'Alene, Idaho

December 12, 2006 


\section{TABLE OF CONTENTS}

Introduction:

Page 1

Chapter 1: Was there a Civil War in the West?

Page 26

Chapter 2: A Call to Arms

Page 50

Chapter 3: The Danger Within: Protecting the Far West from Southern Sympathizers

Page 87

Chapter 4: Southern Schemes and British

Bluster in the Pacific Northwest:

The Department of the Pacific and

the Northern Border

Page 129

Chapter 5: Dissatisfied Spirits, Republicans, Imperialists, and Other Dangers

Along the Southern Border

Page 158

Chapter 6: An Old Problem in a New War:

The Department of the Pacific and White-Native American Relations

During the Civil War

Page 192

Chapter 7: Eorum Bellum Servitium

Page 240

Appendix

Page 256

Bibliography

Page 261 


\section{INTRODUCTION}

The Civil War, although fought largely in the East and Trans-Mississippi, was a transcontinental war. Military service, naturally, differed significantly the farther away one was from the main theatres of the war. With the exception of a handful of battles in 1861 and 1862 in the deserts of New Mexico and Arizona territories, service in the Far west did not resemble the regular campaigning that typified the dominant image of the war. The result of this lack of mammoth battles and hundreds of thousands of deaths is the false belief that service in the Far West was insignificant and routine. The Pacific states and slightly populated territories were much like islands, separated by a sea of wide-open land from the rest of the nation. Those who served their country in this region were certain to be overshadowed, and, eventually, forgotten. As the San Francisco Alta California prophetically noted after the war began, “There is but little glory to be won by serving one's country on the Plains .... No matter how marvelous the achievements it will not get much play."1 Just two years after the war ended, this reality led George Bowie, former commander of the Fifth California Infantry Regiment to ask, "May not we claim to have rendered some services that are worthy of public recognition?”2

It is the object of this dissertation to respond to the colonel's plea. In doing so it will become clear that the nearly 20,000 troops who voluntarily served their nation, sacrificed their energy, sweat, blood, and in some cases, their lives, played an important

\footnotetext{
${ }^{1}$ San Francisco, Alta California, August 11, 1861.

2 George Bowie, “Address,” Society of California Volunteers. (San Francisco: Edward Bosqui and Company, 1867), 5.
} 
role in both the Civil War and the development of the Far West. Through their efforts, they maintained a general stability in a vast region where potential threats and those that were actualized could easily have hampered Union efforts in the main theatres of war. The men and commanders in the Department of the Pacific not only had to quell any internal unrest that might be planned and initiated by secessionists, whether the aim be to join the Confederate armies or establishing the Pacific Republic; they also had to maintain peaceful relations between the various tribes and the flood of whites that continued to flow into the region. When and if those efforts failed and conflicts between the two groups arose, they were charged with putting down the Native American uprisings.

These internal responsibilities were only part of the potential hazards lurking along and within the department's vast territory. As had been demonstrated in 1859 and 1860, the generally harmonious relations with the British in far western Canada could easily turn dangerous. Likewise, after the French began their imperial efforts in Mexico in earnest, department commanders had to ensure that the United States was not drawn into the morass. Thus, contrary to those that have ignored and misunderstood the Department of the Pacific's role in the larger national scene, the commanders and men, who served throughout the war years successfully confronted multiple dangers, both internally and externally, that could easily have altered the nature of the Civil War or the Far West. When assessing the reality of what the veterans of the Department of the Pacific accomplished during the war years, Bowie proudly asserted, “In long, tedious, and weary marches, privations endured, hardships encountered, difficulties overcome, 
and exposure to the dangers incident to the life of the soldier in our wild regions, few have equaled us, and none have been our superiors. ${ }^{3}$

In part because a solitary veteran's views cannot be accepted without further study, and in the larger sense because there is much more to understanding the Department of the Pacific's role in the Civil War than studying what the troops endured, broad questions must be posed and detailed, focused answers determined in order to understand this complex subject. In order to achieve a comprehensive understanding of the role the Department of the Pacific played in the Civil War it must be asked, what were the dangers facing the department during the war, who were the men who answered the call to arms, and how did they carry out the various tasks confronting them. For example, to determine who served in the department it is necessary to ascertain where these men came from, their age, what their occupations were, and what motivated them to enlist. In unearthing the answers to such narrower questions, much can be learned about the state of the Far West both before and during the war years. Thus, by considering the finer points of the general questions within the context of a dissertation level study, it will become clear that the Department of the Pacific played a much more important role in the Civil War than has generally been assumed. Likewise, such a study will demonstrate that the activities of the Union military during the war years had a significant impact on the development of the Far West.

Despite the importance of the Department of the Pacific in both the Civil War and the growth of the Far West during the war, the treatment the subject has received in

${ }^{3}$ Ibid. 
general studies can be characterized in one word, marginalization. This marginalization has happened at the hands of both Civil War and Western scholars. In reality, even the word marginalized understates the situation in most works, where the Far West is ignored by Civil War writers and the war years are passed over by Western scholars.

Considering the two together, the marginalization can be summarized to imply this: the Civil War years in the Far West were a time and place where little of note transpired. Such a position, however, is predicated on the notion that the relative calm that pervaded the vast region during the war meant that little of import, or high drama occurred. To the contrary, what both Civil War and Western historians have failed to recognize is that the calm did not occur from a lack of danger, but that it was the result of a job well done by the commanders and troops serving in the Department of the Pacific.

In general, histories of the war, Civil War historians seem to imply that, with the exception of a few months in 1861 and 1862, when Confederate forces carried the war into New Mexico Territory, the western most border of the United States ended at Texas and the Indian Territory. While this is especially true of military studies of the war, the general dismissal of the importance of the Far West after the Compromise of 1850 is pervasive among the best general studies. Even James McPherson, whose book, Battle Cry Freedom, is probably the best single volume history of the war, makes only one reference to California or the Pacific slope after the Compromise of 1850. In his final comment on the Far West in the Civil War era, he notes, "Several hundred slaves did work in California mines before the state prohibited slavery. Some of them even 
continued to work as slaves after 1850, under court decisions allowing temporary residence of the slaveholders in the state."4

With such prevalent lack of any treatment at all in general histories of the war, it is important to look at more specific studies. Although there are a small number of books that acknowledge the existence of the Far West during the war years, treatment of the western experience varies both in depth and quality. One of the early assessments of the Department of the Pacific’s role was included in a pioneering social historian John Bach McMaster's book, History of the People of the United States During Lincoln's Administration. In a work which might appear to hold the promise of examining the Pacific slope and its people during the Civil War era, McMaster managed to sum up the westerners’ experience in five pages, and almost all of those were devoted to California. McMaster's position was that there were secessionist organizers in the southern portion of the state, but they were chased off to Nevada Territory, where "some two hundred men were easily raised and when organized declared for the Confederacy, raised the rebel flag in Virginia City and defied the Union men to pull it down."5

What of the Native Americans, how did military and civilian leaders deal with them during the war years? Other than department commanders parceling out food to quell one of the motives for Indian uprisings and sending troops eastward to join the fighting, thereby denuding the region of a military force, McMaster has little else to say about relations with the regional indigenous population. In reality there were Native

\footnotetext{
4 James McPherson, Battle Cry Freedom. (New York: Oxford University Press, 1988), 71.

5 John Bach McMaster, A History of the People of the United States During Lincoln's Administration. (New York and London: D. Appleton and Company, 1927), 65.
} 
American uprisings in Oregon, along the emigrant trail, as well as in southern California and the state's Humboldt region. ${ }^{6}$

Fifteen years later, the Far West received even briefer consideration in a study of Copperheads entitled, The Hidden Civil War: The Story of the Copperheads, by Wood Gray. Given the presence of a vocal Copperhead population in California, in particular, this omission is both intriguing and illustrative. Gray managed to sum up the western experience with Copperheads in just over one page. Despite the miniscule consideration given to the far frontier, Gray did make a noteworthy observation when he explained, "the new states west of the Missouri River had comparatively little effect on the outcome of the war. Here recent emigrants from the older sections had had little time for their views to take on much of the color of their new environment.”7 Gray was partially correct, for there can be no disputing that the Far West contributed fewer troops and was the scene of dramatically less activity than states such as Pennsylvania, Tennessee, and Virginia. Gray, however, failed to understand that the result of this lack of a truly far western identity led many of the southern émigrés living in the region to remain strong supporters of their heritage. By summarily dismissing this point, Gray ignores the important role that the 16,000 Californians and the 1,800 Oregonians (whom he did not mention at all) played in suppressing the Copperheads and Knights of the Golden Circle.

\footnotetext{
${ }^{6}$ For more on these uprisings see Carl Schlicke, General George Wright: Guardian of the Pacific Coast. (Norman, Oklahoma, and London: University of Oklahoma Press, 1988), 318 and War of the Rebellion: The Official Records of the Union and Confederate Armies, series 1 (Washington, D.C.: Government Printing Office, 1897), 50: 1, 166-168. For the Native American-white conflict in the Humboldt region see Anthony Bledsoe, Indian Wars of the Northwest: A California Sketch (San Francisco, 1885).

7 Wood Gray, The Hidden Civil War: The Story of the Copperheads. (New York: The Viking Press, 1942), 218.
} 
Most importantly, by dismissing the activities in these states he failed to consider the embryonic plots and actual attempts to seize gold shipments, on land and sea, destined for the East. ${ }^{8}$ Of course, pointing out that Copperheads and their allies did pose a threat to California's gold fields, an important element in maintaining the Union's international economic strength, is well beyond the roughly one page Gray devoted to the Far West.

McPherson, McMaster, and Gray, for all of their brevity, exemplify the typical historiographical treatment of the Far West during the war. All wrote as if California was the only state or territory in existence, or at least the only important one, along the Pacific Coast. Furthermore, they all believed the degree of importance was minimal, at best, and in McPherson's case, it ended after the Compromise of 1850. They dismissed the Department of the Pacific just as effectively as if they had not written about it all, which had been, and continued to be the most common approach.

Brevity was certainly not an issue when Robert Johannsen wrote Frontier Politics and the Sectional Conflict in 1955. Despite the excellent quality of that work, there are limitations to Johannsen's study. The main concern, as it relates to this dissertation, was that he only studied the political struggle in the Pacific Northwest before the war. Given Johannsen’s focus, he argued that, "While the Northwest frontiersmen were busy building a social, economic, and political structure of their own on the far shores of the Pacific, they nevertheless were not too occupied to glance now and again at the political upheaval in the East.”ำ He essentially argued that the Pacific Northwest was an active, if

${ }^{8}$ Two solid studies on the plots to seize gold shipments are Clarence Clendenen, "A Confederate Spay in California: A Curious Incident of the Civil War," Southern California Quarterly 45 (1963) 3, 219233; and, Francis Holbrook, "To Strike a Blow at the California Trade," The American Neptune 32 (1972) 3, 195-210.

${ }^{9}$ Robert Johannsen, Frontier Politics and the Sectional Crisis: The Pacific Northwest on the Eve of the Civil War. (Seattle: University of Washington Press, 1955), 219. 
distant, player in the pre-secession crisis. After all, Senator Joseph Lane of Oregon was John C. Breckinridge’s vice presidential candidate on one of the southern tickets in 1860. As valuable as Dr. Johannsen's book is in making the pre-war atmosphere in the Pacific Northwest clear, it does not consider the war years, or affair in other parts of the military Department of the Pacific.

Others, however, have taken up where Johannsen left off. As war clouds gathered the most significant concern emanating from the Pacific Coast was whether or not the southern inhabitants would attempt to take control of the states and territories. In his master's thesis, Roger Van Winkle argued that although time would show there was less actual danger than many then thought, during the early stages of the war, "it was believed that the size of the anti-war faction was increasing, but also that the secessionist sentiment was considerable” in Oregon. ${ }^{10}$ Recently, another author considered the strength of that secessionist support within the confines of the southwestern-most section of Oregon. In his article, Jeff LaLande noted that many Union Oregonians "feared that rebellion by alleged 'nests of Secesh sympathizers' simmered just below the surface” and that more accurately, such a feeling "played itself out as a kind of rhetorical civil war in that particular corner of the Northwest." ${ }^{11}$

Concerns over the strength of Southern sympathizers in Oregon was one matter, and the threat posed to the most populous and, more importantly for the administration, the wealthiest state in the Far West was another. The potential secessionist/Confederate

\footnotetext{
10 Roger Van Winkle, “A Crisis in Obscurity: A Study of Pro Southern Activities in Oregon, 1854-1865,” (master’s thesis, Western Washington University, 1968), 76.

11 Jeff LaLande, “’Dixie’ of the Pacific Northwest: Southern Oregon’s Civil War,” Oregon Historical Quarterly 100 (1999) 1, 36.
} 
threat to Union control of California has likewise garnered a steady trickle of interest from authors over the past forty years. Although he was not the first to consider the topic of southern designs on California, G. Thomas Edwards' concise article on the subject remains a solid overview of how department commander Edwin Sumner skillfully handled those dangers. In the article, which appeared in Civil War History, Dr. Edwards noted that

the Federal government in 1861 worried about the course that California might pursue and took appropriate steps to keep the state in the Union: it secured posts and weapons; secretly rushed to the far coast a northerner to replace a southerner as commander; occupied portions of the state; and it did not recall the majority of the regulars until absolutely certain that California would remain within the sisterhood of loyal states. ${ }^{12}$

Just as political studies of the Department of the Pacific during the war are fragmentary, military works likewise suffer from a lack of comprehensiveness. Military studies of the Pacific slope during the Civil War focus almost exclusively on a singular region, the fighting in New Mexico Territory. More recent works, however, give a little attention to efforts to maintain a fragile peace throughout the department, but there are only a few works. Included among that group is Ray Colton's The Civil War in the Western Territories, published in 1959, which examines confrontations between various tribes and both Union and Confederate forces in the western territories from the present state of Colorado southward. Other books that examine the Confederate invasion of New Mexico Territory include Robert Lee Kirby’s, The Confederate Invasion of New Mexico and Arizona, and Martin Hall's Sibley's New Mexico Campaign. Although neither work, nor

${ }^{12}$ G. Thomas Edwards, "Holding the Far West for the Union: The Army in 1861," Civil War History 14 (1968) 4, 307. Other earlier studies include Mabel Elizabeth Dodson, "Attempts of Southern Sympathizers to Gain Control of California," (masters thesis, Southwest Texas State Teachers College, 1939); more recently, Laurence Fletcher Talbott, "California Secessionists Support of the Southern Confederacy: The Struggle 1861-1865,” (Ph.D. dissertation, The Union Institute, 1995). 
similarly focused studies, deal much with activity in the Department of the Pacific, Martin Hall made an interesting observation: "If the capture of New Mexico by the Confederates would have rendered the conquest of California probable, then the New Mexico campaign of 1862 should be viewed as one of the most important military operations of the war."13

Works dealing with the Far West during the war have not maintained the initial, and brief, spark of the 1950s, nor have comments like Hall's inspired any one to examine the happenings in the Department of the Pacific. The reason for this, as Hall would point out, is that California was not taken, and in the view of most of those writing about the New Mexico invasion, it was never in any serious danger. This dismissive view is not a true assessment of the reality the department personnel faced during the war, but it remains the dominant view.

The Lincoln administration did not have the benefit of hindsight to assuage its concerns about southern sympathizers in the Far West. Historians, however, do have that luxury. As a result, it is understood that the military conflict in the Department of the Pacific did not mean engaging Confederates, but rather running battles with the various Native American tribes. This is where Western historians (excepting the New Western school of thought) have added to the historiography of the department's role in the Civil War. ${ }^{14}$ It is, of course, important to note that throughout the war years, the department

\footnotetext{
${ }^{13}$ Martin Hall, Sibley's New Mexico Campaign. (Austin, Texas: University of Texas Press,
} 1960), 3.

${ }^{14}$ Patricia Nelson Limerick, the most prominent of the New Western History school of thought, gives nearly no attention to the impact the Civil War had on the development of the West. Like McPherson, her interest in the region during the (pre) Civil War era ends with the Compromise of 1850. For her the West of the 1850s and 1860s appears to mean the Midwest, which she points out played a key role in the coming of the Civil War. Patricia Nelson Limerick, Legacy of Conquest, (New York and 
commanders did the utmost to avoid war with the Native Americans as a whole. In fact, George Wright spent much of his time as commander of the department trying to protect tribes such as the Nez Perce from incursions onto their lands by gold seeking miners. ${ }^{15}$ Of course, Department of the Pacific leaders did not do so out of altruism, but because Indian wars would slow development of the region and cost men and money at a time when both were needed elsewhere. Taken on the whole, the department commanders could claim partial success in this objective. Fighting between whites and certain groups of tribes broke out in both northern and southern California and southern and eastern Oregon continued for most of the war.

Thus, after war broke out in the East in 1861, the threat requiring the most active and vigilant response by the Department of the Pacific was that posed by the region's numerous tribes. This topic is one in which Western historians such as Alvin Josephy and Robert Utley have led the way. However, they are among the few to take up any part of the topic. Both Josephy and Utley wrote books that examine Native Americans and their relations with the Federal government, and its representative in the West, the Army. Josephy's encyclopedic study of the Nez Perce is the best of those works. In it he does an excellent, if brief, job of examining the Nez Perce tug-of-war relationship with the Federal government during the Civil War. ${ }^{16}$

London: W.W. Norton, 1987), 90-94. Also se her Something in the Soil, (New York: W.W. Norton, 2000).

15 See the previously cited, Schlicke, General George Wright.

16 Alvin Josephy, The Nez Perce Indians and the Opening of the Northwest, (Boston and New York: Mariner Books, 1997). Robert Utley’s survey, The Indian Frontier of the American West, 18461890, is useful as supplement. 
Both authors also wrote studies that focus on the military's relationship with the western tribes. Although Utley's book, Frontiersmen in Blue, is based largely on previous publications, he does make an important point, "When the bombardment of Fort Sumter in April 1861 finally plunged the Nation into Civil War, the frontier army suddenly ceased to protect the frontier. Officers whose sectional loyalties drew them into the South resigned almost en masse."17 Josephy looks at the newly created paradigm facing the western soldiers after war broke out, which included how the military dealt with the western tribes during the war, in his book The Civil War in the American West.

The long history of white incursions onto Native American lands leading to conflicts and depredations continued during the war years. As Josephy points out, the worst examples occurred in northern California: "White abuses were particularly flagrant in the northern part of California, where thousands of Indians, driven from their ancestral hunting, fishing, and root-gathering grounds ... were dying of starvation.” In their efforts to avoid starvation, bands of men raided down in the valleys, stealing livestock. As a result of white attempts to exterminate them, "Emboldened by the withdrawal of the Regulars, angry Indians were hitting back,” and war erupted. ${ }^{18}$ The story was the same along the southern and eastern Oregon borders, where miners tramped through Native American lands, fueling the enmity of the tribesmen. Efforts in that portion of the department were mixed, with Snake or Piaute and Bannock Indians attacking small

\footnotetext{
${ }^{17}$ Robert Utley, Frontiersmen in Blue, (New York: MacMillan Publishing Company, 1967), 212.

${ }^{18}$ Alvin Jospehy, The Civil War in the American West, (New York: Knopf, 1991), 241-242.
} 
parties of whites, while at the same time there were concerns that the powerful Nez Perce tribe might follow suit. ${ }^{19}$

The Department of the Pacific commanders and troops faced far more than the dangers posed by potential southern supporters and Native American unrest. As had been demonstrated in 1859 and 1860, even the generally harmonious relations with the British in the far western Canadian colonies could flare up to the verge of conflict with little provocation. The incident that eroded relations between England and the United States in 1859, the so-called Pig War, was not far from the minds of local American and British officials once war came. ${ }^{20}$ As a result of the confusion about who held sovereign authority San Juan Island, both countries maintained a military contingent there, primarily to maintain order among the split population. The continued proximity of British and American military personnel had the potential for disaster should a disagreement between British civilians or soldiers and their American counterparts occur. Robin Winks wrote the best studies about American relations with British Canada, both along the Washington Territorial border and in general. In his more narrowly-focused chapters from his book, Canada and the United States: The Civil War Years, as well as in separate articles, Winks makes it clear that although most British/Canadians harbored no ill will toward the Americans, there was an undercurrent

19 In addition to Josephy’s The Nez Perce Indians, Julianna Moomaw's “Oregon: Patrolling the New Northwest," Journal of the West 14 (1974) 1, 5-24, is also a useful examination of white-Native American relations in Oregon during the war.

20 The Pig War is one of those incidents that might have been, and even though little occurred in the end, the elevated tensions and animosities created, most of which were short-lived, has led to a number of studies. The most recent is Michael Vouri's, The Pig War: Standoff at Griffin Bay, (Friday Harbor, WA: Griffin Bay Bookstore, 1999). Two important primary accounts are Granville Haller's San Juan and Secession, in which Major Haller suggest that armed conflict with the local British troops came very close to happening, and Keith Murray, "Pig War Letters: A Romantic Lieutenant's Account of the San Juan Crisis,” Columbia 1 (Fall) 1987. 
of distrust. Some British leaders in western Canada feared that the American military might mount an invasion of British Columbia, partly on the pretext that Confederate privateers were being harbored in Vancouver Island. ${ }^{21}$

Even more precarious was the situation south of the border. With the French invasion of Mexico, Department of the Pacific commanders faced a difficult task when trying to keep the United States from being pulled into the void created by the imperial war that ensued. To make matters worse, department commanders had to suppress their own sympathies for the Mexican government while trying to control of the inclination of Americans to assist their sister republic against an imperial invader. The Mexican and French representatives in San Francisco inhibited that effort by carrying out an espionage war against each other. As author Robert Miller points out, each employed agents, and in the case of the French, they bribed American officials, in their efforts to aid their cause. According to Miller, based on foreign correspondence, the French held the upper hand in this bit of international intrigue on American soil; "In addition to being a deputy in the Port of Collector's office, Edmund Burk was Chief of Police of San Francisco, and was also a secret agent in the pay of the French government." 22 Clearly the quagmire that was the French invasion of Mexico and the resulting political intrigue by both sides in California posed a serious threat to the stability of the Far West, which was reflected in warnings in official communications to the department commanders. The French

${ }^{21}$ Robin Winks, Canada and the United States: The Civil War Years, (Baltimore: The Johns Hopkins Press, 1960); "Rumor of Confederate Privateers Operating in Victoria, Vancouver Island," British Columbia Historical Quarterly 18 (1954) 3-4, 239-255; “The British North American West and the Civil War,” North Dakota History 24 (1957), 139-152.

22 Robert R. Miller, “California Against the Emperor,” California Historical Society Quarterly 37 (1958), 207. 
conquest of Mexico in 1863, although manifested differently, posed just as much potential danger as the British in western Canada.

Clearly, the officers and troops serving in the Department of the Pacific faced a multiplicity of dangers to the Union during the Civil War. As this overview of the literature demonstrates, their efforts, despite the absence of consideration in general histories of both the war and the West were important for both the continued development of the region and protecting the western most part of the Union. Small examinations, however, have serious limitations when it comes to understanding the importance of what the troops did during the war years. By their nature, articles and small sections within larger works are incapable of addressing all aspects of what the troops faced and achieved during the war and what that meant to the Far West. Given the obvious limitations of these efforts, the question arises, why are there not any comprehensive studies of the role the department played in the war and in the West? The answer to this question is that there have been comprehensive attempts, but the most recent (written over 40 years ago), and by far the best, has never been published.

In 1951 western historian Aurora Hunt completed the first comprehensive study of the Department of the Pacific, or Army of the Pacific as she fashioned it. That work, The Army of the Pacific, 1860-1866, is based largely on the Official Records and old newspaper coverage, and it has important limitations. ${ }^{23}$ The author set out to tell the story of a different army than those in the East, one "which served longer, fought as

23 Aurora Hunt, The Army of the Pacific, 1860-1866, (Glendale, California: The Arthur H. Clark Company, 1951). This study is marred by its antiquated writing style, simplistic conclusions, and sometimes hard to verify research. Therefore, it must be approached with a healthy skepticism about its conclusions and its sources. That having been said, it remains the only published full-length study, and it was reissued in 2004. 
bravely and died as valiantly."24 For Hunt, the story of the Department of the Pacific, in which she examines the southwest as well as the Pacific states and territories, is strictly a military one. She does not delve into the international dangers lurking along both borders (and in some instances, within the department as well). Also, and given when the book was written, not surprisingly, she does not consider the impact the troops and their sacrifices had on the future of the Far West. Even her treatment of white-Native American relations is too narrow, and almost myopic.

In Army of the Pacific, she ignores the fact that the military's primary effort was to negotiate with the tribes, and to at least attempt to protect them from the invading miners. In her book, Native American relations with the troops are examined almost exclusively in confrontational terms. Even in this regard her study misses the mark. Hunt focuses on the conflicts that raged in Arizona Territory (broken off from New Mexico Territory), but since that region was not within the department's borders for most of the war, what occurred there was not the Department of the Pacific's responsibility. She almost completely ignores the military conflicts with tribes in California and eastern and southern Oregon (and late in the war, in what is now southern Idaho). The Nez Perce treaty, and the preference for peaceful relations with all the tribes, gets short shrift. Compounding the problems of what is left out is the antiquated style in which the book is written and her failure to consider how individuals, civilians as well as soldiers (not to mention the Native Americans), were affected by the department's activities. Despite important shortcomings and errors, it must be said that Hunt's study remains the only attempted at a comprehensive book on the topic.

\footnotetext{
${ }^{24}$ Hunt, 13.
} 
Although this pseudo scholarly monograph remains the only published work on the topic; in 1963 it was easily supplanted by a far superior study of the Department of the Pacific. In that year, G. Thomas Edwards completed his dissertation, “The Department of the Pacific in the Civil War,” at the University of Oregon. In this study, Dr. Edwards deftly used available sources, including the Official Records, department reports (not included in the O.R.) and a small number of first person accounts to present a more comprehensive, more accurate, and exceedingly more valuable analysis of the Department of the Pacific during the Civil War. In the more than 40 years since the completion of this dissertation important new primary material has surfaced, and new scholarship touching on individual aspects of the topic have been published. None-theless, to this point that dissertation remains the only accurate and comprehensive work on the topic.

As both Edwards and Hunt learned four and five decades ago, the most significant problem when attempting to analyze the responsibilities facing the Department of the Pacific and what the troops achieved during war is the limited extent primary sources. Because of the comparatively small number of troops who served in the department during the war (fewer than 20,000 of the roughly two million men who served the Union), the quantity of sources is naturally far fewer than any Civil War historian is accustomed to finding. Likewise, Western historians are accustomed to a wealth of primary sources, especially for the 1870s and 1880s. Thus, even under the most ideal conditions, the available pool of first person material is not especially deep.

Conditions were anything but ideal, for as the San Francisco Daily Alta California predicted in 1861 there was little glory in serving the Union in the Far West. This feeling 
hardly improved after the war. Most Department of Pacific veterans, and in fact, the vast majority of the region's population (based on extant primary sources) seemed to dismiss their experiences during the war in favor of the highly romanticized (and largely inaccurate) characterization of the post-war expansion boom.

As a result of these less-than-ideal conditions, it is clear that any study of the experiences of the civilians and military personnel who lived in the Department during the Civil War will confront the dominant theme of marginalization. The persons who experienced those years as civilians and those served in one of the many volunteer military units marginalized their experiences for a number of reasons, preferring to focus on their lives prior to, or after the war. In part, based on this fact, historians have likewise failed to delve very deeply into the subject. The comparative lack of published works on the Far West during the Civil War has undoubtedly played an important role in discouraging both Western and Civil War scholars from considering the role and impact the department had on the war, and on the West. The lack of scholarly studies, however, gives an erroneous impression about both the available sources and the department's impact.

If there is anything resembling a theme among the first person accounts, it is a combination of pride in a job well done with a tinge of bitterness at being ignored or forgotten. When the War of the Rebellion, the Official Records of the Union and Confederate Armies was published beginning in the 1880s, it became the preeminent source of information on the Department of Pacific. However, of the 128 books in the set, just two deal with the Department of the Pacific. 
Unlike the major theaters of operations, where old soldiers wrote hundreds of books and articles, veterans from the Department of the Pacific penned very few first person accounts. Of the few sources, among the best are the papers veterans presented before their fellow comrades in arms at annual banquets. The first such paper set the tone for much of what the veterans wrote. In 1867 the previously mentioned George Bowie, when speaking before his fellow California veterans, related the details of some of his services during the war, concluding that "In long, tedious, and weary marches, privations endured, hardships encountered, difficulties overcome, and exposure to the dangers incident to the life of the soldier in our wild regions, few have equaled us, and none have been our superiors." 25 In later addresses, few of which have survived, the speakers/writers related certain aspects of their service while maintaining Bowie's concern for how that service was recognized.

Three factors combined to cause an almost complete absence of first person accounts of the war along the Pacific Coast. The most obvious cause was that comparatively few soldiers took the field throughout the entire war in the Far West. The situation was similar for the civilian population, which was still relatively small when the war started.

A second factor was that, of the troops who served out the war on the western frontier, most either lamented not being involved in the "real" war to the east or they were eager to put their service behind them and to take advantage of the growing economic opportunities in the region. One brief, although noteworthy exception, came from the pen of a Confederate veteran of the invasion of New Mexico. T. T. Teal, who

\footnotetext{
25 Bowie, 5.
} 
had close contact with the invasion commander, stated that "The objective aim and design of the campaign was the conquest of California .... California had to be conquered." 26 Teel was a genuine rarity, and his comments related to what "might” have happened, but that, in many ways, is what is so important about his statement. Unfortunately, few other first person comments exist.

More important in understanding the drudgery of military service in the department are the few published accounts that touch on that subject. Fortunately, the Civil War centennial sparked interest in the war years on the Pacific Coast. In the midst of the heightened awareness of all things Civil War, two diaries by Oregon infantrymen were published. The first of those books was entitled, All Quiet on the Yamhill. This work, which was published on the eve of the centennial in 1959, was based on the diary of Oregon infantry Royal Bensell, who served at Fort Yamhill in eastern Oregon. The publication of this work, along with the centennial, led scholars to search local archives for other regional accounts of the war. The result was the publication in 1964 and 1965 of another diary and three article-length memoirs by members of the First Oregon Cavalry, It is from sources like these that we learn that the First Oregon Cavalry's Captain John Drake believed his troops "were fine material for frontier soldiers, accustomed to the use of firearms and the care of horses; and notwithstanding their inferior numbers the huge task of keeping things straight in that vast extend of wilderness and desert was faithfully and efficiently performed.”27 Although few in number, such

${ }^{26}$ T.T. Teel, "Sibley's New Mexico Campaign - Its Objectives and the Causes of It's Failure," in Battles and Leaders of the Civil War (New York: The Century, 1884-1888), 2, 700.

27 John Drake, “The Oregon Cavalry,” Oregon Historical Quarterly, 65 (1964), 399-400. 
primary sources provide valuable insight about the men who served in the department and the nature of that service.

A third factor that led to marginalization by the war generation was that there was high turnover at the departmental level. In the first months of the war there were three commanders, each of whom died before the end of June $1865 .^{28}$ The deaths of threefourths of the Department of the Pacific commanders created a void that could not be filled. Their deaths eliminated the possibility of memoirs giving the departmental command perspective. This also meant that veterans did not have an authoritative figure and his/their story to coalesce around .

To a large degree, civilians living in the vast territory encompassed within the Department of the Pacific also marginalized their experiences during the war years. For those that had lived in the region since it earliest frontier days, the tendency was to write about the difficult first years of trying to carve out an existence from the wilderness, whether as a farmer or miner, in elusive pursuit of gold. Others, who came just prior the war, tended to stress the boom years that followed the war. While both tendencies provide excellent context when considering the war years in the larger western experience, the amount of first person information for the war years is limited.

Limited, however, does not mean nonexistent. Partisan sentiments ran high and, as can be gleaned from those accounts that do reflect on the Civil War era in the Far West, it is clear that the population was far from complacent. As one miner noted, “When soldiers came to town and got to drinking, they were slurred as 'Lincoln's

28 The first commander, Albert Sidney Johnston was killed at the April 1862 Battle of Shiloh, while in command of the Confederate army. General Edwin V. Sumner, the second department commander, died of natural causes in March 1863 after leading a corps in the Army of the Potomac. Only the last departmental commander, General Irvin McDowell, who replaced Wright, survived the war. 
Hirelings' to kill Southern people," and sometimes southern sympathizers made “a soldier or volunteer drink to the health of Jeff Davis or Beauregard."29

This sense of marginalization by both veterans and civilians can be offset, to a certain degree, by using unpublished sources. While there are important accounts that add valuable information to the history of the Department of the Pacific's role in the Far West during the Civil War, those sources are also few in number. Generally speaking, there are just two institutions holding the bulk of unpublished veteran-generated material. A small number of valuable veteran memoirs and papers are housed at the Oregon State Historical Society, in Portland, Oregon. Not surprisingly, since most of the department's troops came from California, the largest collection of veteran accounts is held at the Bancroft Library at the University of California at Berkley.

While the majority of unpublished military accounts, almost all it seems, are housed in just two places, civilian memoirs and collections of papers, are scattered in small numbers throughout the western states. Considering the published primary sources, along with key archival holdings, it is apparent that while perhaps paling in comparison to the literal tonnage of source material that most Civil War and Western historians are accustomed to, there exists a solid foundation of primary materials upon which to base a study of the Department of the Pacific's role in the Civil War.

So with just two previous works attempting a comprehensive examination of the Department of the Pacific's role in the war what can a third, dissertation-level, study add? By considering what impact the soldiers' service had on the developing West, a greater understanding of both the military's role in that growth and the importance of the war

${ }^{29}$ Doyce B. Nunis and Nora B. Cunningham, editors, The Golden Frontier: The Recollections of Herman Francis Reinhart, 1851-1869, (Austin, Texas: University of Texas Press, 1962), 204-205. 
years becomes possible. Achieving the goals laid out for this dissertation means not only looking at old topics differently it, more importantly, means asking new questions altogether. By doing so, this study will not only expand on the valuable work done by Edwards forty years ago, it will also put the same general topic, the Department of the Pacific, in a broader context.

This study will begin by asking a simple question Hunt and Edwards chose not to pursue in any depth: just who made up the military in the Department of the Pacific during the war? The answer to that question will provide much more than just the demographic background of the troops; it will also make it possible to consider what motivated them to enlist. The answers to those questions can, in turn, provide insights into what life was like for thousands of men who, after migrating to the West, eventually chose to serve their (sometimes adopted) country.

Another key element to this study, which was ignored by Hunt and only lightly touched upon by Edwards, is analyzing the political role George Wright and the other department commanders played in the relations with the British in Canada and the French and Mexicans to the south in Mexico (and the presence of their operatives within borders of California). Both authors failed to consider just how important a role the Department of Pacific played in maintaining American stability along its borders. Not giving the international dimensions of what was done by the Department of the Pacific provides an incomplete picture of the importance of what the commanders did, and the difficulties they faced. This study will strive to demonstrate that sympathies for the Mexican cause might have pulled the Far West, and by extension the nation, into the international mess in Mexico. Likewise, as was demonstrated only a year before the outbreak of Civil War 
when American and British officials engaged in localized brinkmanship diplomacy over the San Juan crisis, initially, relations with our British cousins could quite easily have degenerated to the point of conflict.

Even though the military analysis that will make up an important component of this study will benefit from the groundwork done by Edwards, and to a lesser degree Hunt, even that aspect of this study will differ from its predecessors. This study will synthesize forty years of new topical studies on the various military tasks performed by the commands in the Department of the Pacific. Doing so will mean reconsidering the military's role in preempting any secessionist uprisings as well as its main tasks of trying to prevent, or if that failed, to suppress Native American uprisings. When considering those military activities, this study will benefit from the publication of a number of primary sources that have come to light in the last forty years.

This study will do what the trickle of narrowly defined works cannot, and what Hunt chose not to do, namely put the Department of the Pacific in the larger context of the Civil War as well as the development of the West. By asking different questions than Edwards, this study aims to exceed the scope of contextual boundaries of that work as well. In essence, the design here is to construct a broader-based analysis of the Department of the Pacific, which will include looking at the social as well as military and political activities and results achieved by the roughly 20,000 troops in this forgotten theatre of the war.

Thus, this dissertation will demonstrate that the Department of the Pacific provided valuable and successful assistance to the Union cause during the Civil War and that in doing so it encouraged the continued westward migration that marked the gold and 
silver rush years that preceded the war. This study will move beyond the two previous works to address these bisecting topics, the most recent of which is forty years old. Furthermore, where there have been occasional articles or odd pages devoted to narrowly-defined, fragmentary aspects of the Department of the Pacific's role in both the Civil War and the growth of the West, this study will connect those elements into a cogent study of the department as a whole. It will place the more specific topics within the contextual whole. Doing so will supplant the implied message of insignificance that has thus far pervaded general histories of the war with the more accurate argument that not only was the Department of the Pacific an important element in the Union cause, but the efforts of those serving there throughout the war stabilized the region during an overlooked period in western expansion. Where western histories have ignored the war years, this study will demonstrate how the almost exclusively volunteer military forces' success so stabilized the region that the flow of people into the vast area's farmlands and ore fields continued unabated during the war. In effect, the success of the commanders and troops in the Department of Pacific during the war not only protected the Far West for the Union, but in so doing it contributed to the rise of Far West on the national scene. 


\section{CHAPTER}

\section{WAS THERE A CIVIL WAR IN THE WEST?}

On April 24, 1861, the passenger ship Golden Age arrived safely in San Francisco harbor 12 days and 19 hours after leaving Panama. ${ }^{1}$ It had been 13 years since one of John Sutter's employees had curiously picked out some shiny flecks, which turned out to be gold, in dirt overturned while digging a millrace. Those first few bits of gold ignited the Gold Rush. In the intervening years San Francisco became the urban center on the nation's farthest western shores. According to the 1860 Federal Census, the city's population numbered 56,802, a number which grew dramatically each year. ${ }^{2}$ By 1861 the arrival of cargo ships laden with supplies, mostly destined for the gold fields and boomtowns that grew around them, was routine. Likewise, passenger ships such as the Golden Age disgorged themselves of thousands of people each year.

This arrival, however, was anything but routine, for the ship carried one of the two things that altered the atmosphere and, to a discernable degree, the lives of America's western most citizens. Those stepping down onto the Folsom Street Wharf included a gruff looking, white-haired 64-year-old man, who happened to be a recently promoted general in the United States Army. ${ }^{3}$ Early the next day that man, Edwin Vose Sumner, presented himself at the office of Brevet Brigadier General Albert Sidney Johnston.

\footnotetext{
1 J. T. Watkins commanded the Golden Age. San Francisco, Daily Alta California, April 25,1861.

${ }^{2}$ As of the 1860 Census, San Francisco was the fifteenth largest city in the United States. Statistics of The United States in 1860 Compiled from the Original Returns of the Eighth Census, (New York: Arno Press, 1976), xviii.

${ }^{3}$ San Francisco Daily Alta California, April 25, 1861.
} 
Johnston commanded the recently created Department of the Pacific, or rather he did until Sumner presented a directive from U. S. Army headquarters ordering him to turn command over to Sumner. ${ }^{4}$ Sumner's arrival meant the expansion and alteration of the already complex military responsibilities in the region. Its new, or greatly enhanced, responsibilities included protecting the region from Confederate incursions, internal unrest, and unstable relations along the borders with Canada and Mexico. Simultaneously, the troops continued, with increased vigor, such long-standing responsibilities as guarding the overland mail (and soon telegraph) routes and protecting the white population from Native American depredations.

Although Sumner had been ordered to relieve Johnston in March, his assumption of command was providential for the Lincoln administration in light of another important item arriving in the city that day. Arriving by Pony Express from Missouri was the news that Confederate forces had fired on and eventually compelled Fort Sumter, in the Charleston, South Carolina harbor, to surrender almost two weeks earlier. The war, which California played no small part in bringing on, was at hand. ${ }^{5}$

The firing on Fort Sumter and the arrival of Sumner initiated dramatic changes for the troops stationed in the Department of the Pacific. Although far from the scene of the coming battles, the Far West posed concerns for the Union government. Primary among the federal government's fears was that the region, and California in particular, might

4 War of the Rebellion: A Compilation of the Official Records of the Union and Confederate Armies, series 1, 70 volumes in 128 parts (Washington D.C.: Government Printing Office, 1897), 50, 1: 469. Hereafter, unless otherwise noted, all references to the Official Records are to this series, volume, and part, and will be abbreviated as O.R.

${ }^{5}$ For an account of the role the admission of California played in the widening sectional rift see David M. Potter's classic, The Impending Crisis, 1848-1861, (New York, Philadelphia, San Francisco, and London: Harper Torchbooks, 1993), chapters four and five. 
become contested ground like Missouri or Kentucky. Even worse, there was the possibility that the region would either join with the Confederacy or form an independent nation, as had been the talk in the 1850s. Thus, the most paramount responsibility facing Sumner and the Department of the Pacific was protecting the Far West for the Union. Although the fear of a pro Confederate insurrection in the region was the preeminent concern, it hardly represented the only threats facing the new commander. As the newly arrived Sumner soon found out, the troops in the Department of the Pacific had to protect against Native American uprisings, potential threats from the British in Canada and shortly from being embroiled in the troubles between the Mexicans and French in Mexico. Accomplishing these tasks became more difficult as the years passed and most of the Regular Army commands transferred east to bolster the volunteer forces that made up the bulk of the Union armies. Thus, to understand fully the impact the troops in the Department of the Pacific had during the war years, it is paramount first to consider the responsibilities they shouldered during the war.

Protecting the Far West, especially California, from the threat of Confederate invasion or uprisings by Confederate sympathizers was the Lincoln administration's biggest concern on the Pacific Slope as the war began. Despite its still relatively limited population, California gold and Nevada silver contributed mightily to the nation's economic well-being. This fact alone dictated that the state, as well as the other ore rich regions of the Far West, not fall into Confederate hands. The possibility that the military installations in the state might be turned over to Confederate sympathizers was precisely the reason the War Department sent Edwin Sumner to San Francisco. The governmental and military authorities in Washington D.C. feared that the Department of the Pacific 
commander, General Johnston, might defect to the Confederate cause and turn over control of the arsenals and forts to either Confederates or Confederate sympathizers. As unlikely as that might seem to some, the fears were well founded, if unfair to the professional Johnston.

Johnston's path to the command of the Far West began when the previous commander of the Department of California, Brevet Brigadier General Newman Clarke, died October 17, 1860. ${ }^{6}$ On October 31, Johnston’s former aide, Major Fitz John Porter, who then worked for Commanding General of the Army, Winfield Scott, inquired whether or not he was interested in assuming command of the region. Johnston agreed and Secretary of War John Floyd made the official appointment. ${ }^{7}$

On November 22 the War Department issued Special Order Number 10, reconstituting the Department of the Pacific, which had been subdivided into two separate divisions in 1858. Although recreating the Department of the Pacific added a new level of bureaucracy, it streamlined the command structure for the War Department, which now dealt directly with one commander instead of two. Of course, recreating the department on paper in Washington D. C. and putting it into practice in the Far West were different matters. It was not until January that the Department of the Pacific

\footnotetext{
${ }^{6}$ It is important to remember that at the time of Clarke's death that the western most section of the country was divided into two departments, being the Departments of California and Oregon, whereas Johnston assumed command of a single department covering the same territory.

${ }^{7}$ Charles P. Roland, Albert Sidney Johnston: Soldier of Three Republics, (Austin, TX: University of Texas Press, 1964), 241. There has been some speculation that the appointments of Johnston to the Department of the Pacific and Brevet Major General David E. Twiggs to the Department of Texas by Floyd was part of a plot to put both regions under southern control should a war break out. The notion gained currency during the early days of the war when all three men were eventually appointed Confederate generals, but not before Twiggs surrendered his command to Texas authorities.
} 
received its new commander. On January 15, 1861, Brevet Brigadier General Albert S. Johnston arrived in San Francisco to assume command of the recreated department. ${ }^{8}$

In most regards Johnston, who possessed vast administrative as well as field experience, was a solid choice for the post. He was an 1826 graduate of West Point who had fought in the Texas Revolution, eventually serving as the Republic of Texas' Secretary of War. Later he led a regiment in the Mexican-American War, commanded the Department of Texas from 1856 to 1858, and then commanded the military expedition against the recalcitrant Mormons in Utah Territory. ${ }^{9}$ Thus, it appeared that the U.S. Army's new man in the most distant region of the country was well-suited for his post. Unfortunately for Johnston, he assumed command as the country careened toward civil war. Under such circumstances, the tall Kentuckian faced not only the usual array of problems that awaited all commanders of the region, but also the danger posed by those who wished to wrestle its control from the federal government, as well as potentially hostile relations along both the northern and southern borders.

During Johnston's brief tenure in command, he oversaw a massive department far removed physically, but not immune, from the deteriorating situation in the East. As the secession crisis boiled, the department's already daunting task of protecting the flow of people moving into the vast territories encompassed within its borders, as well as the overland mail route that served as a tenuous connection to the rest of the country, became even more complex. With the onset of the war, the department faced additional responsibilities. The most paramount task that emerged was the need to protect the Far

${ }^{8}$ O.R., 433.

${ }^{9}$ Ezra J. Warner, Generals in Gray (Baton Rouge and London: Louisiana State University Press, 1983), 159. 
West, and especially California, from internal Confederate sympathizers and the dangers posed by Confederate elements from Texas.

Those concerns ensured that Johnston's tenure in command was destined to be brief. Even as he issued orders to streamline the department's defenses against both internal and external threats, his loyalties and connections to the South caused deep personal turmoil. Rumors that Johnston planned to establish an independent nation on the Pacific Coast only exacerbated his dilemma. Despite his personal sympathies for the southern states, he vehemently denied he would dishonor his commission, telling his son, "I say the whole charge is false in every particular.... If the War Department has such information, why don't they order an investigation and not give it to letter writers to damage the reputation of officers?”10 Although he felt honor-bound to carry out his responsibilities to the utmost of his abilities, he mulled the decision to tender his resignation and leave for Texas.

While Johnston deliberated over where his loyalties lay, events elsewhere convinced officials in Washington D.C. that they needed someone more firmly committed to the Union in charge of the nation's most distant region. Specifically, Abraham Lincoln's assumption of the presidency in early March, combined with the earlier surrender of all Union commands in the Department of Texas on February 18, convinced the high command in Washington that it had no time to waste. The surrender of the Department of Texas caused particular alarm about the security of the Department

${ }^{10}$ Robert Kirsch and William S. Murphy, West of the West, (New York: E.P. Dutton and Company, Inc., 1967), 568. 
of the Pacific. ${ }^{11}$ Experienced officers with solid reputations, Johnston in the Pacific and Brevet Major General David Twiggs in Texas, led the two departments, and both were southerners. Furthermore, many in the military as well as among the civilian population, believed that each sympathized with the seceded states. ${ }^{12}$ In this atmosphere, what the War Department felt was Twiggs' inexplicable capitulation cast a long shadow of doubt about Albert Sidney Johnston’s loyalty.

The Department of the Pacific commander, despite his southern background and sympathies, was not, however, David Twiggs. From his arrival in the Department of the Pacific, Johnston acted with alacrity in responding to both regional and high command concerns. When he received orders to strengthen the entrance to San Francisco, he reinforced Fort Point and ordered the commander at Alcatraz Island "to maintain your post and defend against all efforts to seize it, from whatever direction such efforts may be made."13 When frightened citizens in the northwest coast region of California petitioned Johnston for protection from marauding tribesmen, he not only sent a detachment of Regulars, he urged Governor John Downey to call up a militia contingent. ${ }^{14}$ Clearly,

11 The losses, both in troops and supplies, were staggering. The Texans valued the stores, munitions, ordinance, and various forts and camps at over two million dollars. As a result of the surrender 2,689 U.S. troops, roughly fifteen percent of the total Army strength, were either escorted from Texas or held for two years as prisoners of war. Phillip R. Rutherford, “Texas Leaves the Union,” Civil War Times Illustrated 20 (1981) 3, 23.

12 For a highly partisan view of Twiggs' actions by an officer who escaped from Texas after the surrender of U.S. forces, see Albert Brackett’s, “Escaped from Texas,” Philadelphia Weekly Times, November 11, 1886.

13 O.R. 448. For the War Department's orders to Johnston and his Special Order 18 transferring troops from Fort Vancouver to San Francisco see, O.R., 434 and 443-44, respectively.

14 Johnston's exchanged of letters with concerned citizens in the Humboldt district as well as with Governor Downey, see Ibid, 457-459. 
unlike Twiggs, who vacillated terribly in the absence of any clear guidance from the War Department, Johnston executed his responsibilities with an active and even hand. ${ }^{15}$

What those in Washington D.C. did not know for certain was that Johnston determined not to dishonor either his commission or his reputation. Echoing what he had written his son previously, he told Governor Downey, "I have spent the greater part of my life in the service of my country ... and while I hold her commission [I] shall serve her honorably and faithfully." 16 Even so, when the news that Texas had seceded reached San Francisco, he made up his mind to resign his commission, telling his sister-in-law, "I felt, as soon as I learned the course adopted by my State [Texas] that it was my duty to conform to her will." ${ }^{17}$ On April 9 Johnston sent his letter of resignation to the Adjutant General of the United States Army, requesting "that my successor may be appointed and ordered to relieve me as soon as possible.”18

Although he did not know it, Johnston did not have long to wait for his replacement to arrive at department headquarters in San Francisco. Concern about the potential threat from pro-southern elements in the Far West had become a topic of discussion at Army headquarters in Washington D.C. in early January. General Scott’s military secretary, Colonel Erasmus D. Keyes, recalled urging the general to take steps to

15 The War Department, which dismissed Twiggs from the U.S. Army in March, seemed to forget its own culpability for the debacle in Texas. Much of Twiggs' indecision resulted from the vague and dilatory responses to a number of requests for guidance which he sent the War Department as the crisis in Texas grew more volatile. For Twiggs' numerous requests for instructions between December 13, 1860, and February 4, 1861, see O.R. 1: 579-586.

${ }^{16}$ Quoted in Roland, Albert Sidney Johnston, 245-46.

${ }^{17}$ Ibid, 247.

${ }^{18}$ O.R., 463-64. 
protect San Francisco harbor in mid-January. ${ }^{19}$ Less than a week later, the Adjutant General's office issued orders to transfer two companies of artillery from Fort Vancouver to a post at the entrance to San Francisco harbor. ${ }^{20}$ Two months later, the high command's concerns were no longer limited to external threats. Officials were increasingly concerned about dangers from within the Department of the Pacific. Rumors spread eastward that Johnston planned to turn the entire department over to Confederate sympathizers the way Twiggs had handed over Texas. ${ }^{21}$

Rumors of this sort were rampant at the time; however, this one reached the newly-seated Lincoln administration via a source that could not be ignored. Oregon senator James Nesmith informed Secretary of State William Henry Seward "that General Albert Sidney Johnston, commanding the Department of the Pacific, was unfaithful to the Union.”22 During a private meeting with General Scott on March 22, Seward expressed his concerns. Both men agreed that someone with unquestioned loyalty to the Union should replace Johnston. "The following morning the general wrote an order for Colonel E.V. Sumner to proceed without delay to San Francisco and assume command of the Department of the Pacific. The order was approved by the Cabinet in secret session Colonel Sumner embarked [from New York] by stealth.”23 This was the man who

${ }^{19}$ Erasmus D. Keyes, Fifty Years' Observation of Men and Events Civil and Military. (New York: Charles Scribner's Sons, 1884), 353.

${ }^{20}$ O.R. 434.

${ }^{21}$ Author Robert Chandler believes that Virginia born California politician, Edmund Randolph was the source of the rumors. Robert J. Chandler, "The Velvet Glove: The Army During the Secession Crisis in California, 1860-1861,” Journal of the West, 20 (1982) 4, 39.

${ }^{22}$ Keyes, Fifty Years Observation, 420.

${ }^{23}$ Ibid. Sumner was promoted to brigadier general before his departure, thereby giving him rank commensurate with his new post. 
arrived on April 24 aboard the Golden Age. It was on his shoulders that the military and civil authorities thrust the varied responsibilities that came with command of the vast Department of the Pacific.

The arrival of his replacement should have been a great relief to Johnston, however, he realized the War Department could not have acted that quickly on his resignation. He therefore understood that the decision to replace him had not been his own. Instead of being pleased by his release from command, he was angry that officials in Washington had questioned his loyalty. ${ }^{24}$ Sumner's immediate assumption of command, on the twenty-fifth, was announced to the department with the issuance of departmental Special Order Five. ${ }^{25}$

Edwin Sumner's arrival in San Francisco, along with the news of the attack on, and capture of, Fort Sumter, ushered in the Civil War era for the men serving in the United States Army's Department of the Pacific. Local newspapers ran special bulletins and posted the news on bulletin boards announcing Fort Sumter's surrender. In the wake of the onset of war, the new department commander initiated a frenzy of activity designed to address the high command's chief concern, the retention of the Far West in the union.

Sumner's responsibilities were numerous, multifaceted, and daunting. Like previous commanders in the region, he served two masters, the federal government and the civilian population. Unlike his predecessors, however, all of whom except Johnston focused their main attention on Native American relations, Sumner's primary task of

\footnotetext{
${ }^{24}$ Roland, Albert Sidney Johnston, 249.

${ }^{25}$ O.R., 469.
} 
preserving federal dominance over the Pacific slope superseded all other responsibilities. ${ }^{26}$ This did not relieve troops of their other tasks, but rather added to those tasks. Not only did Sumner and his far-flung command have to ensure the region did not leave the Union or degenerate into chaos like Missouri, they still had to deal with the numerous Indian tribes, which threatened emigrant trails and overland mail routes, while protecting the sovereignty of both the northern and southern borders.

Immediately upon assuming command, Sumner initiated changes designed to protect the left arm of the republic from external threats by Confederate forces. At the same time, he took measures to squelch any internal schemes by expatriated southerners or southern sympathizers. In less than a week, he issued a string of orders designed to concentrate troops in the areas of greatest danger. These moves included immediately ordering a unit of artillery from Fort Vancouver and two others from the District of Oregon to San Francisco, and the abandonment of Fort Mojave, in order to concentrate its command in Los Angeles. ${ }^{27}$ These were just the first of many changes that affected the disposition and make up of the Union forces on the Pacific Coast.

It is clear from the rapid issuance of a number of special orders during Sumner's first five days that the initial steps to secure the Far West were mapped out before he arrived. Despite his belief that Union sentiment pervaded in the Pacific states and territories, Sumner realized his situation was not enviable. Just four days after arriving, he perceptively noted that although the Unionists were the most numerous, "the secessionists are much the most active and zealous party.” As a result he had "no doubt

26 Johnston split his attention between strengthening the department's defenses against external threats and protecting the white population from Native American aggression.

27 O.R., 469-70, 473. 
but there is some deep scheming to draw California into the secession movement.” It was his belief that "the course of events in the East will control events here," which given the surrender of Fort Sumter, was not at all comforting. If the situation in the East continued to deteriorate, "The troops here now will hold their positions. . . but if there should be a general uprising of the people, they could not, of course, put it down." ${ }^{28}$ Given the uneasiness about the status of the region, Sumner's cautiously optimistic assessment of his new post could hardly have assuaged officials in the capital.

The general belief was that the most virulent and highest concentration of the Confederate sympathizers lived in southern California. ${ }^{29}$ It was this belief that led Sumner to order the abandonment of Fort Mojave, which enabled those troops to be restationed in Los Angeles from the far less important desert post. Contributing to the concerns about southern California was the realization that a large proportion of the population was Mormon, and they held no affinity for the federal government. ${ }^{30}$ Southern California, clearly, was not the only region in the Far West with a discernable southern population. Due largely to the false lure of easy riches in the many gold (ore) fields throughout the region, the entire department was home to a cosmopolitan population. As the Alta California put it, "Our population is composed of emigrants from

${ }^{28}$ All quotations in this section are from a letter sent by Sumner to Army headquarters in Ibid, 472.

${ }^{29}$ In August 1861 a group of San Bernardino citizens informed the local military commander that there was an effort underway to organize a pro Confederate force that would first attack San Bernardino and then head eastward toward Confederate forces in New Mexico Territory. O.R., 554-555.

${ }^{30}$ Ibid, 548-549. The local military commander, Brevet Major James Carleton estimated that 1,000 of San Bernardino's 1,500 people were Mormons and most of the rest were "adroit horse thieves and other unprincipled and desperate men." 
every State of the Union. California is the United States in miniature.”31 Actually, the population was even more diverse than any one place in the rest of the country. In addition to the hundreds of thousands from the eastern states, many of them southerners, there was a large Hispanic population, generally referred to as Californios, a small number of Chinese miners and laborers, and European immigrants that had drifted across the continent, none of which had any particular reason to be loyal to the federal government.

Although Sumner and the War Department were primarily concerned about the security of California, sectional unrest throughout the rest of the department could not be ignored and required vigilance as well. While California was the key to securing the region, there were dangers in other sections of the vast department. According to one Puget Sound resident, “At an early stage in the great civil war it became apparent that there were in California, Oregon, and Washington men ready to aid in the destruction of the Union by every means within their power.” ${ }^{32}$ Given the sparseness of the population of most of Oregon and virtually all of Washington and Nevada Territories, these areas presented limited opportunities for pro-Confederate elements to overthrow federal control of the Far West. Nonetheless, such persons could pose a local danger in the numerous mining towns throughout the region, where "sometimes [they] would make a soldier or volunteer drink to the health of Jeff Davis or Beauregard.”33 Despite focusing much of his efforts on California, Sumner understood that stifling internal scheming in the effort

31 San Francisco Daily Alta California, April 27, 1861. 1969), 51.

32 Charles Prosch, Reminiscences of Washington Territory. (Fairfield, WA: Ye Galleon Press,

33 Doyce B. Nunis, Jr. and Nora Cunningham, editors, The Golden Frontier: The Recollections of Herman Reinhart, 1851-1869. (Austin, TX: University of Texas Press, ) 205. 
to keep the Far West in the Union required vigilance throughout the entire department, for as Captain Hugh Gorley noted, he and the other soldiers "felt as though we were upon a volcano of social disruption." 34

Sumner and the War Department were not only worried about the potential internal volcano, but also the external threat. Sumner's actions upon assuming control made it clear that the high command feared an external threat nearly as much as it did an internal cabal. Judging by the relocation of a significant number of troops to San Francisco and the abandonment of other posts, it appears the consensus was that if an attack materialized, it would come from one of two directions, either by sea against San Francisco or by land from Texas or Mexico against southern California. Thus, another of the Department of the Pacific's enhanced responsibilities was to protect the region against a Confederate attack.

Just as the troops in the department had to be vigilant against external land-based threats, they also had to be wary of sea borne operations directed at San Francisco. As evidenced by War Department orders sent to General Johnston in mid January, as well as General Sumner's first steps once he assumed command, it is clear the high command genuinely feared such an attack on the West Coast's largest port city. Thus, it was paramount that the commanders of the Department of the Pacific ensure that federal forces could turn back any Confederate advance from the sea.

The frenzy to prepare San Francisco harbor for defense against an external assault seems baseless in historical hindsight, but it persisted throughout the war years, as evidenced by the almost comical energy all four department commanders spent to

${ }^{34}$ Hugh Gorley, "The Loyal Californians of 1861," Military Order of the Loyal Legion of the United States. (Wilmington, NC: Broadfoot Publishing, 1995), 60, 200. 
strengthen the defenses. ${ }^{35}$ Despite the massed artillery, the commanders never felt the city was entirely secure and as a result strengthening and protecting the Pacific Coast, and especially San Francisco, remained a key component of their responsibilities. Although the concern focused on an attack from the sea, during which a stealthy sea captain might use the bay's notorious fog to shield an approach, the only danger that came close to materializing occurred from within. ${ }^{36}$ On March 15, 1863 marines and San Francisco police thwarted the culmination of a wild scheme to capture the schooner, U.S.S. Chapman. ${ }^{37}$ From that point on the city’s residents gave more credence to the wild rumors and the Department of the Pacific moved to quell those fears. The Chapman Affair added a new twist to the department's attempts to protect the Far West from proConfederate danger.

The considerable efforts spent to protect the Far West from the Confederate and pro-southern elements only served to complicate what had long been the military's primary responsibility in the region, maintaining the peace between non-Indians and Native Americans when possible, and protecting the American citizens at all costs. With the continued flow of immigrants into the vast lands encompassed in the department, the commanders faced the difficulty of protecting those people with a limited force that was needed elsewhere. Enlarging the military presence in and around San Francisco, as well as in southern California, necessitated moving the scattered commands like chess pieces.

35 In a recent master's thesis, Donald Bastin put the number of heavy artillery protecting the harbor at over 200. Donald Bastin, "Rebels at the Gate: Civil War San Francisco and the Confederate Seaborne Threat,” Master Thesis, (California State University at Hayward, 2001), 2.

${ }^{36}$ Wright believed that if an enemy ship used the fog to slip past the fortifications, which were directed toward the sea, "Once within the harbor she can take a position beyond the reach of the guns of Alcatraz island, and, of course, command the city.” O.R. 2, 294.

37 The Chapman Affair will be addressed, along with the other internal threats, in chapter 5. 
With just over 2,000 men present for duty in the entire department as of June 1861 repositioning troops was not an enviable job. ${ }^{38}$ In some cases the result was the complete removal of a military force from a specific region. Thus, throughout the war, the department commanders had to balance the need to thwart potential pro Confederate threats before they materialized with the need to protect the citizens from various tribes, whose situation grew increasingly desperate each year.

Local citizens, fearing what those tribes would do once the military departed, besieged each of the four successive department commanders with plaintive requests not to remove the military force. Each commander received letters predicting dire consequences if the troops left: "If this protection is to be withdrawn, those who have under its promise made their homes in the wilderness will be left to the mercy of ruthless savages, and a beautiful district about to be reclaimed by civilization again abandoned to its original condition." 39 Fortunately, the first three of the department's commanders had spent many years dealing with the Native Americans on the western frontier. They understood that relations between non-Indians and the tribes were frequently volatile and potentially deadly ${ }^{40}$ Only the last commander, Major General Irvin McDowell, who

\footnotetext{
${ }^{38}$ O.R., 525.

39 O.R., 437.

40 Johnston, Sumner, and Wright all dealt with or commanded troops in the field against the
} western tribes, but it was Wright, who commanded the department for the longest time, who spent ten years prior to the war on the West coast, who understood the these tribes the best. For Wright's pre war experiences, see Carl Schlicke, General George Wright: Guardian of the Pacific, (Norman, OK and London: University of Oklahoma Press, 1988). 
spent most of his military career as a desk officer, did not have experience dealing with the western Indian population. ${ }^{41}$

While McDowell performed staff work and Johnston and Sumner confronted problems elsewhere, George Wright had learned the nature of dealing with far western tribes when the region endured a string of bloody Indian wars in the 1850s. Although generally ignored in favor of the more widely publicized Indian wars of the 1870s and 1880s, the decade before the Civil War had been a bloody one in the Far West. Wars raged in Washington Territory’s Puget Sound, the Yakima valley, and along what is now the eastern border of the state. Before Oregon became a state it endured the Rouge Indian War at nearly the same time that northern Californians fought the First Modoc War. Although all these conflicts were resolved before the Civil War started, the memories were fresh for both the Americans and the Indians. The wars left an indelible impression even on friendly tribes, such as the powerful Nez Perces who "never forgot how the American army had treated the Indians who surrendered” during Wright's 1858 campaign in Washington Territory. ${ }^{42}$

Just as the wars sputtered to a conclusion at the end of the decade, Native American depredations in northern California flared up again in 1861. The pleas from the area's frightened citizens led to the creation of a new district in the Humboldt region of northwest California. ${ }^{43}$ Attacks also persisted along the immigrant trails and the mail route. To discourage such attacks necessitated dispersing elements of the various

41 Ezra J. Warner, Generals in Blue, (Baton Rouge, LA: Louisiana State University Press, 1964), 298.

42 Alvin Josephy, The Nez Perce Indians and the Opening of the Northwest (Boston and New York: Houhgton Mifflin Company, 1997), 384.

43 O.R., 760. 
regiments throughout the department. The complex task of protecting the non-Indians and the Native Americans from each other remained the most nagging problem facing the Department of the Pacific during the war.

The steady flow of farmers, and especially miners, who altered the population dynamics of a region seemingly overnight, were the root cause of the troubles. Driven by the successive ore discoveries throughout the department and the fertile farming lands, the population continued to grow throughout the war years. The violation of reservation boundaries, combined with the generally poor treatment the Native Americans continued to receive during the 1860 s, eroded the already fragile relationship between the immigrants and the Indians. This, in turn, meant the military continued to have its hands full with an old problem.

Department of the Pacific commanders and men faced another lingering problem during the war years, namely dealing with the British to the north. Despite sharing a common background, relations between the British in far western Canada and the Americans had been contentious for many years. In fact, in the years immediately preceding the Civil War the situation along the Washington Territory-Canadian border had careened toward a conflict between the two nations. Although that situation subsided, the British neutrality policy during the war strained relations between the two governments. On the Pacific Coast, this policy meant that Confederate raiding ships could enter Canadian ports in Victoria, British Columbia, and repair, refit, and, relax before setting out to raid Union commercial vessels. The occasional presence of Confederate vessels so near the department's boundaries along with those not always 
harmonious relations necessitated that the Department of the Pacific commanders (as well as the British governor) keep a wary watch north of the border.

The most volatile situation between the two countries since the Oregon boundary confrontation, which was at least temporarily settled in 1846, occurred because of a pig, and was fomented by aggressive American officers. ${ }^{44}$ After an American living on San Juan Island in Puget Sound killed a pig owned by the Hudson Bay Company in 1859, tensions rose precipitously. The Pig War, as this almost comical confrontation was called, was more bluster than bite, but it strained diplomatic relations almost to the point of breaking. ${ }^{45}$

During the war, the suspicions that lingered from the Pig War cast long shadows on both sides of the border. Even as General Sumner recalled the Regular troops from throughout the region for transportation to the main theatre of war, he rescinded a directive to abandoned San Juan Island -which would have effectively handed it back to the British. ${ }^{46}$ As the war progressed, a far more important concern faced the department commanders. The Confederate sea raiders that wreaked havoc on United States ships in the Pacific Ocean were allowed to enter the British port at Victoria, Vancouver Island. Victoria, it was feared, was also a haven for pro Confederates who plotted attacks on the Far West, possibly by land, but more probably by sea. Throughout the war, most

${ }^{44}$ For an excellent treatment of Anglo-American relations during the Oregon boundary dispute in 1845-46 see, David Pletcher, The Diplomacy of Annexation, (Columbia, MO: University of Missouri Press, 1973), especially chapters 11-13. An older, yet still useful work is Norman Graebner, Empire on the Pacific, (New York: The Ronald Press Company, 1955), especially chapters 6-7.

${ }^{45}$ For secondary accounts of the Pig War see, J. Tim O’Gorman, “The Pig War,” Master’s thesis (University of Idaho, 1980) and Michael Vouri, The Pig War: Standoff at Griffin Bay, (Friday Harbor, WA, Griffin Bay Bookstore, 1999).

${ }^{46}$ O.R., 521. District of Oregon commander, (then) Colonel George Wright, realizing the importance of the military presence on the island, rescinded the order even before receiving the communication from Sumner. Ibid, 519. 
potential threats were local in nature, but the region was not immune to national difficulties such as the fallout from the 1861 seizure of Confederate diplomats headed for England. ${ }^{47}$ Despite the lack of serious problems in the region, department commanders deemed Puget Sound unstable enough that one of the few Regular Army units left in the region during the war remained on San Juan Island. In short, the commanders of the Department of the Pacific could not assume the northern border was entirely secure.

British officials, like their counterparts to the south, continued to be suspicious of what the Americans might do during the war. Early on, the governor of Vancouver Island, James Douglas, believed that Union moves into British Columbia as well as onto Vancouver Island were inevitable. His response was to strike first, and to take control of all of Puget Sound before department commanders sent volunteer commands to replace the departing Regular forces. ${ }^{48}$ As fanciful as this scheme appears, other influential persons had previously expressed similar impressions of American intentions. Years earlier, British Prime Minister Lord Palmerston had assessed the Americans, stating, "they always keep pushing on their encroachments as far as they are permitted to do so; and what we dignify by the names of moderation and conciliation, they naturally enough call fear." 49

47 A political upheaval erupted between Washington and London over this action, know as the Trent Affair. Author Dean Mahin puts the Trent Affair in the context of the Union's greater diplomatic challenges in his book, One War at a Time, (Washington, D.C.: Brassey’s, 200), chapter 5.

${ }^{48}$ Benjamin F. Gilbert, "Rumors of Confederate Privateers Operating in Victoria, Vancouver Island,” The British Columbia Historical Quarterly, 18 (1954) 3-4, 241.

${ }^{49}$ Palmerston quoted in Norman Ferris, Desperate Diplomacy: William H. Seward's Foreign Policy, 1861, (Knoxville, TN: The University of Tennessee Press, 1976), 15. 
Governor Douglas was not the only one who tentatively watched American activity in the Department of the Pacific. In 1863 a rumor reached London that troops in California were being organized for an invasion of British Columbia via Washington Territory. ${ }^{50}$ Whether the result of local concerns about aggressive American actions or driven by far off difficulties between the two nations, such as the Trent Affair, relations with the British required deft handling on both sides of the border. Mismanagement might lead to a confrontation deadlier than the follies of the Pig War.

During the war, official relations between England and the United States in the Far West were clear, although not always harmonious. Clarity was not, however, the case with American relations in Mexico. By 1863, the commanders of the Department of the Pacific faced a fluid situation in Mexico. At the outset of the war the United States enjoyed friendly diplomatic relations with Benito Juarez’s Mexican government, but when the European powers became involved in internal Mexican affairs, it claimed neutrality. Remaining neutral as the French began taking over the country may have been pragmatic, but it was hardly popular. American sentiment remained with the Juarez's government as it moved from one location to another, staying just one step ahead of French forces. In January 1862, California governor, John Downey, summed up how many Americans felt: "Three of the great Powers of Europe have now combined to force monarchial institutions and aristocratic privileges upon that living embodiment of Disunion principles, the Republic of Mexico .... The same Powers will combine to enforce aristocracy and royalty upon Americans. ${ }^{\text {51 }}$ Although committed to a neutral

\footnotetext{
50 Gilbert, “Confederate Privateers,” 250.

${ }^{51}$ Downey speech cited in William Lawrence Shaw, The Impact of Napoleon III Upon the Pacific Coast, (Sacramento, CA: California Civil War Centennial Commission, 1963), 11.
} 
policy between the belligerents, Department of the Pacific commanders Wright and McDowell both remained apprehensive of any northward movements by either the French or Mexican forces. Clearly, it was the former that posed the real danger to the sovereignty of the department's borders. However, being pulled into the morass by either party would have been detrimental to the Union war effort, no matter how sympathetic Americans felt toward the Mexicans.

The neutrality the administration desired was difficult to enforce among a populace that despised the establishment of a monarchy in Mexico. This sentiment enabled Mexican agent General Placidio Vega to purchase arms and recruit men easily for Juarez's forces from his base of operations in San Francisco. ${ }^{52}$ Efforts were made to thwart such activities, but national policy could not dictate how the general populace military as well as civilians -felt.

For the Department of the Pacific commanders and men, the potential threat from Mexico, however, was not merely derived from the presence of a monarchical force or the possibility of being pulled into an imperialistic war. Almost from the outset of the war, both Confederate and Union leaders viewed the northern Mexican states as an invasion route pointed either at Texas or the farthest section of New Mexico Territory (now Arizona) and California, depending on who did the planning. Rumors, usually spread by well-intended civilians, bedeviled all levels of command in the department throughout the war. Thus, as early as June 1861 then-department commander General Sumner warned the commander at Fort Yuma, on the California -New Mexico Territory border, that

52 Ibid, 13. Vega's actions were an open secret to American officials. 
a rumor is prevalent in this community and the State generally that the so-called government of the Confederate States purpose sending from the State of Texas or elsewhere, through certain States of the Mexican Republic, to this coast a military force, considerable in number, with the object of seizing upon and holding the port of Guayams [Mexico] . . . It is well to be prepared for any movement. ${ }^{53}$

Similar fears led Wright, and later McDowell, to send forces into New Mexico Territory (and later keep them there). The troops stationed in southern California, deemed the hotbed of pro Confederate sympathies in the department, also kept a vigilant eye peering south and southeast, to prohibit an invasion force linking up with local sympathizers. Even the commanding general, Lieutenant General Ulysses S. Grant, took the potential Confederate threat from within Mexico seriously. In January 1864 he was concerned enough that he telegraphed department commander McDowell that pro-Confederate elements in the Mexican state of Sonora might try to organize an invasion force. If news confirming this fear reached McDowell, Grant advised him that "these apprehensions [would be] well founded, prepare to meet them. You will find no difficulty in raising any number of volunteers that may be necessary in California to repel an invasion of the State.”54 Whether the danger came from the French, Mexicans, or Confederates and their sympathizers, the southern border, like that with Canada, remained a problematic responsibility for the Department of the Pacific throughout the war.

Whether facing external Confederate or internal pro Confederate threats, potential incursions from foreign powers, or dealing with the justifiably angry Native Americans, it was clear that the commanders and troops faced a myriad of challenges in their efforts to hold the Far West for the Union while protecting the region's citizens. Throughout the
${ }^{53}$ O. R., 524.
${ }^{54}$ O.R., 50, 2: 1118. 
Civil War, successfully carrying out their responsibilities required deft handling of difficult responsibilities by both the leaders and men in the Department of the Pacific. Although no one could have known it at the time, their share in a four year struggle began on April 25 when news that Fort Sumter surrendered - days earlier - reached the Pacific coast with the arrival of the ship Golden Age in San Francisco. 


\section{CHAPTER}

$-2-$

\section{A CALL TO ARMS}

Less than a month after the first major battle of the Civil War the San Francisco Daily Alta California prophetically stated, "There is but little glory to be won by serving one's country on the Plains.... No matter how marvelous the achievements it will not get much play.”1 Historically speaking, this prediction has generally held true. Those who served in the Department of the Pacific during the Civil War have more or less been lost in the literary (and literal) tonnage of material written about the war. However, the truth was different; as Colonel George Bowie put it, "In long, tedious, and weary marches, privations endured, hardships encountered, difficulties overcome, and exposure to the dangers incident to the life of the soldier in our wild regions, few have equaled us, and none have been our superiors." ${ }^{2}$ Perhaps veterans who experienced the gore of the fields of Gettysburg or the slaughter at Franklin might disagree, but it cannot be denied that the officers and men of the Department of the Pacific rendered important service to the Union during the Civil War.

As war clouds darkened the national sky in early 1861 the reconstituted Department of the Pacific faced a myriad of responsibilities with a limited force. Once war came, however, those responsibilities both increased dramatically and became more complicated. Beginning in March the War Department made an increasingly difficult task even more troublesome when it began ordering Regular Army commands east to the

${ }^{1}$ San Francisco Daily Alta California, August 11, 1861.

${ }^{2}$ George W. Bowie, “Address” Society of California Volunteers, (San Francisco: Edward Bosqui and Company, 1867), 5. 
main theatre of war. The 2,245 troops present for duty in January were reduced to just over 2,000 men by June, and that number shrank significantly during the coming weeks. ${ }^{3}$

With the departure of the Regular Army forces from the Far West, citizens and politicians worried that the population's safety and security in that remote part of the country had been sacrificed for the greater endeavor in the East. In July, the War Department finally took steps to rectify that problem. On July 24 the War Department sent an order to raise one infantry regiment and five cavalry companies to both Governor John G. Downey of California and General Sumner. ${ }^{4}$ Raising those troops did nothing to assuage the citizens' fears, as once the commands were organized, they were to proceed to Nevada to protect the mail route. In partial response to continuing local concerns as well as the need to maintain the advantages gained over pro-Confederate elements early on, in August the War Department sent another request to Governor Downey to raise five additional regiments of volunteers for three years service. ${ }^{5}$ Although the Regular Army forces served well throughout the first months of the war, most of them were needed elsewhere; therefore, volunteers from Oregon and later Washington and Nevada territories, made up the majority of the forces in the Department of the Pacific. It was their task to guard against internal and external threats from Confederates and their sympathizers, to guard the department's (and the nation’s) borders, and to police the tenuous communication threads connecting the West with the main part of the country. It also fell to them to battle the tribesmen who threatened communications and emigrants. With all these responsibilities, it was only natural for Colonel Bowie to ask, "May not we

\footnotetext{
${ }^{3}$ O.R., 428 and 525.

4 Ibid, 543.

5 Ibid, 569.
} 
claim to have rendered some services that are worthy of public recognition?”6 Before addressing this question, it is important to consider the background of the military's presence in the region. Once that is understood, then it must be determined who served in Department of the Pacific during the war, where they came from, what motivated them and what they felt about their service to their country as well as how they viewed themselves. Only after more is known about whom they were and what they represented can there be, in later chapters, an examination of the services and sacrifices they made for their nation during that time of national cleavage.

On February 2, 1848, Mexican and American officials had formally signed the Treaty of Guadalupe Hidalgo, ending the Mexican-American War. The lopsided military affair evinced America's growing military might. It was the military's resounding success that enabled expansionist political leaders to exact the one-sided treaty from Mexican officials. On the whole, the military's performance during the war was its finest hour since a mixed force of militia, Continental soldiers, and French army and naval commands received the surrender of Lord Cornwallis at Yorktown in 1781. For all the national benefit gained from this tremendous land acquisition, the military created a monumental problem for itself.

The vast lands encompassed in the treaty were only lightly occupied in 1848, but that changed a year after America assumed ownership. Roughly two weeks before the treaty was formalized gold had been discovered near the small town of Sacramento. Although it took almost a year for that information to circulate throughout the existing

\footnotetext{
${ }^{6}$ Bowie, 5.
} 
states, the prospects of becoming wealthy and independent unleashed a flood of people heading toward a previously unknown place in a little understood part of the continent. What had been a massive addition to the nation with unknown potential, requiring limited involvement almost immediately demanded political and military attention.

While the rush of humanity to California caused a great deal of political strife much sooner than anyone anticipated, it also created serious problems for the United States military. The post war military establishment was a victim of its own success. As President James K. Polk stated in his final State of the Union message in 1848, "The events of the late war with Mexico .... [have] demonstrated that upon the breaking out of hostilities not anticipated, and for which no previous preparation had been made, a volunteer army of citizen soldiers equal to veteran troops, and in numbers equal to any emergency, can in a short period be brought into the field." ${ }^{\text {A }}$ After the MexicanAmerican War ended, the vast majority of troops who helped win the war were no longer needed. Fortunately for the government, since volunteers made up the majority of the forces that fought in Mexico, the end of the war meant the end of their service. After reverting to approximately its pre war size, the Army faced the prospect of garrisoning and patrolling numerous parts of the newly acquired lands far sooner than anyone could have anticipated. Given the rapid development and populating of the western frontiers, the Army confronted the difficult task of having to perform enhanced duties with roughly the same force as before the war.

From the outset of the United States' assumption of control of the Far West, it became obvious that the Army was stretched too thinly to protect the emigrants and lend

${ }^{7}$ Fred L. Israel, editor, The State of the Union Messages of the Presidents, 1790-1966, 3 volumes (New York: Chelsea House - Robert Hector Publishers, 1966) 1: 733. 
authority to governmental control over the region. With the general resolution of the Oregon boundary dispute between England and the United States combined with the land cessions from Mexico, the government, as Polk told Congress, had to address “the continuance of Indian disturbances and of the destitution and defenseless condition of the inhabitants” in the region. ${ }^{8}$ Military commanders and most presidents understood well how to confront the problems: the military needed to be enlarged, and soon.

Despite the obvious need to enlarge the Army as well as the Navy to more effectively protect the growing number of citizens in the West, politicians remained tepid to military and presidential pleas. For 13 years presidents, secretaries of war, and Congress wrangled over the need to enlarge the army, and if so, to what extent. Two impediments plagued those hoping to enlarge the military between 1848 and 1861, and they were the same two that dogged national leaders before (and since): the fear of standing armies and, most importantly, the cost. The former carried philosophical weight, but it was the latter that stymied nearly every attempt to expand the military. Every political leader in Congress knew at least one thing about America’s military force; it cost a great deal of money to maintain a large permanent force. Given the fact that the military was expanded just twice during those thirteen years, there was never a large enough contingent in the West to stem the fears of either local civilians or politicians. ${ }^{9}$

Even the Indian wars that broke out in the modern states of California, Oregon, and Washington during the mid-to-late 1850s failed to persuade politicians in

\footnotetext{
8 Ibid, 747.
}

9 Robert Utley provides a good summary of the struggle to expand the military in his, Frontiersmen in Blue: The United States Army and the Indian, 1848-1865, (New York: Macmillan Publishing Company, Inc., 1967), 10-17. 
Washington D.C. to enlarge the army. In the midst of these conflicts, President Franklin Pierce, who managed to wrestle an increase in the military from Congressional leaders, informed Congress that "the state of the service permit[ed] but few and small garrisons in our permanent fortifications." ${ }^{10}$ With eastern politicians concerned about monetary issues on one side and the small, but growing, population in the western regions calling for protection on the other, the western military commands were placed in an impossible situation.

It was impractical to attempt to meet western concerns with a force that numbered less than eighteen thousand (throughout the entire country) yet the military did its best. In Oregon and Washington Territory alone there were more than a dozen forts or other military posts, which did not include temporary camps. The Department of California also included more than a dozen posts of one type or another. ${ }^{11}$ Garrisoning those facilities proved difficult during calm times and nearly impossible during active campaigns, which necessitated that Regular Army commands spend extended periods in the field.

Such a massive expanse of lands required an equally impressive construction of facilities and outlay of troops to address everyone's concerns. However, the military maintained a comparatively small number of posts with the pitifully small army sanctioned by the politicians. Such a situation required spreading the western commands dangerously thin. One young lieutenant in the $1^{\text {st }}$ Dragoons recalled a rather comical example of just how few troops were stationed in the Far West during the 1850s.

${ }^{10}$ Israel, 906.

${ }^{11}$ Robert W. Frazer, Forts of the West, (Norman, OK: University of Oklahoma Press, 1972), 1112, 19-35, 127-133, 167-177. 
Following the conclusion of the 1855 Yakima Indian war, Lieutenant Phil Sheridan remembered that when two officers filed charges against each other, "General John Wool, the department commander, had not at command a sufficient number of officers of appropriate rank to constitute a court., ${ }^{12}$

Two important and far reaching results came out of the military's western experiences during the 1850s. First, by maintaining a national army that numbered less than eighteen thousand, volunteer commands did much of the campaigning during some of the Indian - white conflicts. ${ }^{13}$ Second, in its effort to stretch too few men over too many thousands of miles, the military perfected the policy of parceling out small elements of its western regiments. In fact, it was impractical to reconstitute an entire regiment in the field against the highly mobile tribesmen. ${ }^{14}$ Both factors influenced the experiences of the troops in the Department of the Pacific during the Civil War.

When Albert Sidney Johnston assumed command of the Department of the Pacific in January 1861, his 2,245 men garrisoned 28 permanent posts, as well as a number of temporary camps, from Fort Colville in far northeastern Washington Territory to Fort Yuma on the border between California and New Mexico Territory (present day Arizona). ${ }^{15}$ Those scattered forces came from five regiments, three infantry $\left(1^{\text {st }}, 4^{\text {th }}\right.$, and

12 Philip H. Sheridan, Personal Memoirs of P.H. Sheridan, 2 volumes, (New York: Charles L. Webster and Company, 1888), 1: 69.

13 Utley, 12.

${ }^{14}$ Another problem that made any such gathering of the various regimental elements in one endeavor difficult was the problem of supplying such a large force in the distant and lightly-inhabited region.

${ }^{15}$ O.R., 428-429. 
$\left.9^{\text {th }}\right)$ and one each of cavalry ( $1^{\text {st }}$ dragoons) and artillery $\left(3^{\text {rd }}\right) .{ }^{16}$ The ranks, by regulation, were filled primarily with young men. ${ }^{17}$ Most of the junior officers, like Lieutenant Sheridan and Captains George Pickett and Winfield Hancock, were in their thirties. Naturally, the field grade officers, such as Johnston and Wright were the oldest (the former turned 58 a few weeks after his assumption of command and the latter was already 59 as of January). ${ }^{18}$

Like every other military department, southerners dominated the Department of the Pacific's officer corps at the start of the war - twelve of whom later served as Confederate generals. ${ }^{19}$ The enlisted men came from virtually anywhere, but as one soldier from Virginia noted in 1855, “There is some of most every nation in the army, less Americans than any other.”20 The reason so many foreign-born men enlisted in the army was simple economics. Freshly arrived and unable to find work, they made perfect targets for recruiters. German national Eugene Bandel’s experience was not unique:

16 Ibid.

17 Recruiters were to be "white male persons above the age of eighteen, and under thirty-five years, being at least five feet four and a half inches high.” Of course, they were also required to have a competent knowledge of the English language, which given the practice of recruiting immigrants was hardly the case. Robert P. Wettemann, Jr., "A Virginia Soldier in the Frontier Army: The Letters of Sergeant John R. Whaley, Second U.S. Artillery, 1854-1859,” Military History of the West, 29 (1999) 1, 65.

18 Ezra J. Warner, Generals in Gray, (Baton Rouge, LA: Louisiana State University Press, 1983), 159; Warner, General in Blue, (Baton Rouge, LA: Louisiana State University Press, 1986), 574. At 43, Brevet Major Lewis Armistead was typical of those at his grade. Warner, Generals in Gray, 11-12.

19 By comparing the Official Records, 50:1 with Warner's Generals in Gray, I have come up with the following list, which may not be complete, as Warner implies others may have served in the Department of the Pacific that are not mentioned in the O.R. The twelve are: J.J. Archer, John Adams, E. Porter Alexander, Lewis Armistead, Richard Garnett, Edward Johnson, Albert Sidney Johnston, Armistead Long, William Mackall, Dorsey Pender, George Pickett, and James Smith.

${ }^{20}$ Wettemann, 73. See his footnote 2 for the author's discussion of the percentage of foreignborn soldiers in the pre war army (as high as 2/3 in one tabulation), 63-64. 
I had sold everything I owned that was of value. I owed six dollars at my boarding house. I did not know what to do. By chance I saw a flag hanging from a house and under it a sign. It was a notice that the United States wanted recruits for the army. This was my only resort if I did not want to steal or beg. I went in. I was accepted soon enough and sworn in. I was bound to remain a solider for five years, for clothes, lodging, and food, and eleven dollars a month. ${ }^{21}$

There were plenty of native sons whose luck also ran out, such as John Whaley, who enlisted because, "I see very plainly I can never make anything while I stay here [Virginia] for I get further behind every year that terminates." ${ }^{22}$ This was the Regular Army that held the Pacific Coast for the federal government as war neared in the early months of 1861 .

At first Johnston, and then General Sumner, continually redeployed the Department of the Pacific's limited force of Regulars, abandoning posts in one spot to strengthen key points elsewhere. It soon became apparent, however, that to address the increasingly complex responsibilities required a larger force. This became even clearer during the late summer when the War Department began recalling most of the Regulars for service in the East. Maintaining the defenses left by the departing troops became a primary concern for department commanders (Sumner at first, but it mostly fell to General Wright) and the region's political leaders, such as California governors Downey and his successor Leland Stanford, Oregon governors John Whiteaker and Addison Gibbs, as well as the territorial governors of Washington (William Pickering for most of the war) and Nevada (James W. Nye).

${ }^{21}$ Eugene Bandel , Frontier Life in the Army, 1854-1861, Ralph P. Bieber, editor, Olga Bandel and Richard Jente, translators, (Philadelphia: Porcupine Press, 1974), 72.

${ }^{22}$ Wettemann, 70. 
In July, after the Union defeat at Bull Run, Virginia, the War Department instructed General Sumner to accept a regiment of infantry and five cavalry companies of California volunteers “to aid in protecting the Overland Mail Route.”23 Continued Union failures throughout the summer in the East made it imperative to concentrate all Regular Army commands possible in that area. Hence, in October most Regular Army commands were ordered east once volunteer units relieved them. ${ }^{24}$ This, in turn, necessitated the War Department request that the states and territories raise more troops, with responsibilities far in excess of protecting the mail routes.

Recruiting troops, under any circumstances, in the most distant section of the country was not easy. In order to fill the ranks of the planned regiments, recruiting posts had to be established in the few population centers. In the Far West, San Francisco and Sacramento were the only true cities, but there were population bases throughout northern and central California, with smaller pockets in the southern part of the state. There were smaller population centers in Oregon’s Willamette Valley, in the Portland Vancouver region, and to a lesser degree, along Puget Sound and coalesced near Fort Walla Walla in Washington Territory.

As became clear during the war, the California commands filled their ranks more easily than the Oregon, Washington, or Nevada units. In 1861, when it came time to raise men for the $1^{\text {st }}$ California Infantry, recruiters like Lieutenant George Pettis set up offices in both San Francisco and Sacramento. Pettis, himself, joined the regiment in Sacramento and in October went to San Francisco and there "commenced business by

${ }^{23}$ O.R., 543.

${ }^{24}$ For examples of those very specific orders see General Order 23 and Special Order 43, Department of the Pacific, in O.R., 645 and 649. 
opening his recruiting office on the corner of Montgomery and Clay streets, in the same building with the Morning Call" newspaper. ${ }^{25}$ In three months he recruited enough men to fill his regiment's Company K. Working in similar fashion the remainder of the $1^{\text {st }}$ California Infantry was recruited entirely in the San Francisco area and "assembled and organized at a camp situated in the City of Oakland ... . It was named Camp Downey, in honor of the Governor of the State.”26 In fact, the $1^{\text {st }}$ and $2^{\text {nd }}$ California Infantry regiments were recruited in the San Francisco region, as were many companies in the $6^{\text {th }}$ Infantry and $1^{\text {st }}$ and $2^{\text {nd }}$ California Cavalry regiments. ${ }^{27}$

Although many of the California regiments were recruited in the region between Sacramento and San Francisco, that pool of potential recruits was not infinite. Recruiters from the $4^{\text {th }}$ California Infantry targeted towns in the northern mining districts, such as Placerville, Shasta, and Auburn. The regiment even included a company raised in sparsely-populated San Diego. ${ }^{28}$

Recruiting for the two Oregon and one Washington regiments from the widely dispersed and much smaller population proved challenging. Colonel Thomas Cornelius, the original commander of the $1^{\text {st }}$ Oregon Cavalry, encountered this problem when trying to recruit men for his regiment in November 1861. The colonel raised one company at Salem, while his second in command, Lieutenant Colonel Reuben Maury, recruited two

\footnotetext{
${ }^{25}$ George Pettis, "Frontier Service During the Rebellion or a History of Company K, First Infantry, California Volunteers,” in Soldiers and Sailors Historical Society of Rhode Island, third series, (Providence, RI: Rhode Island Historical Society, 1885), 8-9.

26 Richard Orton, Records of California Men in the War of the Rebellion, 1861 to 1867, (Sacramento, CA: State Office, 1890), 321.

27 Jerome A. Watrous, The Union Army, 8 volumes, (Wilimington, NC: Broadfoot Publishing Company, 1998), 4: 410-417.

28 Ibid, 412.
} 
companies along the Oregon-California border in just one month. However, due largely to the limited population in Josephine and Douglas counties, attempts to fill companies there were not as successful. By early1862 recruiters in those counties still had not yet filled their assignment of two companies. The same situation prevailed in Portland and The Dalles. Frustrated by Cornelius' failure to recruit a full regiment, in the middle of February the department commander instructed the colonel "to perfect the organization of six companies of your regiment, according to the plan indicated. The remaining four companies will not be organized until further notice.”29 On March 16 Cornelius reported that recruiting efforts in Portland, Oregon City, Salem, and The Dalles finally enabled him to fill this reduced number of companies. ${ }^{30}$ This was seven months after he was assigned the responsibility of recruiting a full regiment.

Colonel Cornelius' experience in raising a regiment, although more difficult than his counterparts in California, were far from the least successful attempt to raise a regiment in the Department of the Pacific. On October 12, 1861, Justus Steinberger was appointed a colonel of volunteers and ordered to raise the $1^{\text {st }}$ Washington Territorial Infantry Regiment. After losing two precious months, General Wright prodded "Col. Justus Steinberger to repair to Fort Vancouver and commence raising and organizing the regiment of infantry authorized by the Secretary of War." ${ }^{31}$ Anticipating the impossibility of recruiting a full regiment in Washington Territory, Steinberger asked for, and received, permission to recruit most of his companies in California. The long
${ }^{29}$ O.R., 890.
${ }^{30}$ Ibid, 935.
${ }^{31}$ Ibid, 746. 
delayed process finally got underway in late February, when Steinberger reported that newly-appointed company officers were at last actively recruiting troops for his regiment.

As anticipated, efforts in Washington progressed slowly, leading Steinberger to inform departmental headquarters "I have intelligence only from Captain [R.V.] Peabody on Puget Sound, and the report exhibits very little progress.” As bleak as Peabody's news was, it was more than the colonel knew about the recruiting efforts near Fort Dalles. ${ }^{32}$ Finding men in California willing to serve in a Washington command was not easy either; therefore, Steinberger's recruiters cast a wide net, working in Alameda, Calaveras, Santa Clara, Santa Cruz and Sacramento counties. ${ }^{33}$ In this way, after organizing eight companies of Californians, the $1^{\text {st }}$ Washington Territorial Infantry eventually reached regimental strength. Although Steinberger's experience was not typical, none of the recruiters raising troops from among the cosmopolitan population, so far removed from the main conflict, had an easy time filling the ranks.

The problems confronting recruiters everywhere went beyond the region's limited population. They also faced the difficult task of inducing men, who, for the most part, had come to the Far West in pursuit of wealth in the gold fields, to abandon their dreams and join the military. Complicating this already difficult task was the fact that most men who contemplated joining wanted to chastise the Confederates on the battlefields in the East. As the editor at San Francisco's Daily Alta California noted, performing the important, but comparatively unexciting task of garrisoning and patrolling the Far West and keeping a watchful eye on Confederate sympathizers and Native Americans alike had

\footnotetext{
32 O.R., 978.

33 Ibid, 900, 977-978.
} 
little appeal. Both political and military officials understood the problems facing recruiters, and did what they could to assist in the various efforts to raise troops. Aided by politicians and many newspaper editors, recruiters employed a number of strategies to get a man to enlist, including appealing to his sense of patriotism, encouraging potential recruits to believe they would serve in the East against Confederates, and, if all else failed, using the universal strategy of appealing to a man's economic concerns with monetary incentives.

The first recruiters in California, either out of their own ignorance or recognizing the difficulties facing them, published calls to arms that did nothing to dispel the prevailing opinion that recruits would be sent east to fight Confederates. A member of the $2^{\text {nd }}$ California Cavalry remembered "how bitterly disappointed the great majority of the boys were when this order [to proceed to Nevada Territory] came, as we fully expected to go to Washington City, and from there to the front." ${ }^{34}$ The scene was repeated throughout the department. James Shelley experienced a similar disappointment when he joined the $1^{\text {st }}$ Oregon Infantry. "How anxious we all were," he recalled years later, "to have the opportunity to go East and participate in the real struggle, though the Recruiting officer, doubtless knew we would be kept on the [Pacific] Coast.”35

Early on recruiters recognized that letting potential recruits believe they were destined for glory in the main theatre of operations proved a winning strategy. Although each individual had his own reason for joining, many were compelled by feelings of

\footnotetext{
34 “Tamarac,” “A Lost History: Experiences of Co. A, 2d Cal. Cav., Not Recorded Officially,” National Tribune, March 26, 1896.

35 James Shelley, “Military Reminiscences of James M. Shelley ,” Oregon Historical Society, Portland, Oregon, 3.
} 
patriotism and what better way to express that patriotism than join up to fight the

Confederates. As it turned out for everyone who served in a California, Oregon, Washington, or Nevada command, they had to prove their patriotism far from the titanic battlefields in the East. ${ }^{36}$

Politicians as well as recruiters believed that appealing to an individual's patriotism was a good strategy to fill muster rolls. One of Colonel Justus Steinberger's unsuccessful recruiters in the Puget Sound region encouraged enlistment with a broadside that announced: “TO ARMS! TO ARMS!! TO ARMS!!! 'Eternal Vigilance Is the Price of Liberty!!!” It reminded the "Fellow-Citizens of the United States in Washington Territory" that "He who prates of love of country and will not place himself in readiness, in time of danger, to defend it, is unworthy of that proud name we all bear, AMERICAN CITIZENS." ${ }^{37}$ As noted previously, the effort ultimately proved futile, forcing the colonel to raise most of his command in California.

During the drive to raise men for the $1^{\text {st }}$ Oregon Infantry, state politicians, working with local newspaper editors, targeted influential men in counties where recruiting was underway. They reminded them that "men are needed promptly, and every consideration of patriotism and of State, local, and personal pride” required them to "respond to this appeal by earnest and successful work."38 Appealing to patriotic fervor

${ }^{36}$ The exception to this reality were the small commands raised in late 1862 known as the 'California Hundred" and the "California Battalion,” which served in the $2^{\text {nd }}$ Massachusetts Cavalry. Two recent studies of the service rendered in the eastern theatre are, James McLean, California Sabers: The $2 d$ Massachusetts Cavalry in the Civil War, (Bloomington, IN: Indian University Press, 2000) and Thomas E. Parson, Bear Flag and Bay State in the Civil War: The Californians of the Second Massachusetts Cavalry, (Jefferson, NC and London: McFarland and Company, Inc. 2001).

37 “An Old Shout for Preparedness,” Washington Historical Quarterly, 7 (1916) 2: 176.

38 Shelley, 2. 
during national crises had the predictable effect. As William Hilleary, who joined the $1^{\text {st }}$ Oregon Infantry on Christmas Eve 1864, explained, "My reason for enlisting was that I felt that I owed the service to the best government on the earth, that rebels were trying to overthrow." ${ }^{39}$ Like Hilleary, George Hand, a sergeant in Company G, $1^{\text {st }}$ California Infantry, was also driven by patriotic commitment to serve, saying he joined "as I had never before served my country, I thought it my duty to do so." ${ }^{40}$ The officers in the various regiments were no less patriotic than their men. Assessing the role patriotism played in encouraging men of all ranks to join the $1^{\text {st }}$ Oregon Cavalry, $2^{\text {nd }}$ Lieutenant James Waymire noted, "I will say here that from my personal knowledge I know that a great majority of the men who composed the First Oregon Cavalry were young men acting from a conviction of patriotic duty." 41

As key as patriotic fervor was to encouraging men to join the volunteer forces in the Department of the Pacific, patriotism alone, did not lead every recruit to enlist. In fact, as the war dragged on and it became clear that none of the commands recruited in Oregon, California, or Washington and Nevada territories would be sent east, raising troops became more difficult. To offset that effect, recruiters in the Far West responded in the same manner as those to the East. With the support of both local and state government officials, and aided by civilian funds, recruiters offered monetary incentives to induce men to join. These incentives, more commonly known as bounties, played a

39 Herbert Nelson and Preston Onstad, editors, A Webfoot Volunteer: The Diary of William M. Hileary, 1864-1866, (Corvallis, OR: Oregon State University Press, 1965), 32.

40 Neil B. Carmony, editor, The Civil War in Apacheland: Sergeant George Hand's Diary, California, Arizona, West Texas, New Mexico, 1861-1864, (Silver City, NM: High-Lonesome Book, 1996), 9.

41 Waymire report to Oregon Adjutant General Cyrus A. Reed, in Francis Fuller Victor, “The First Oregon Cavalry,” Oregon Historical Quarterly, 3 (1902) 2, 134 
key role in bringing in new troops throughout the war years, but were especially important as it dragged on into 1864 and 1865.

The inherent problem with using bounty incentives was that scheming individuals could, and occasionally did, exploit the system by staying with a command long enough to receive their bounty and then deserting. To combat this, recruiters and officials everywhere began postponing most of the bounty until completion of one's tour of duty, generally set at three years or the duration of the war, whichever was shorter. This had drawbacks, however, and political regulations could be circumvented if local citizen committees wished to provide additional bounties upon enlistment. In this way, some of Private William Hilleary's associates in the $1^{\text {st }}$ Oregon Infantry not only received their state bounties upon completion of their service, but local citizens paid as much as $\$ 50$ in coins to a recruit upon his enlistment. ${ }^{42}$ Savvy Oregon politicians upped the bounties, but stretched payment out over "three equal installments, to be given each enlisted volunteer who should offer his services for a period of "three years or dur[ation of] the war," the last to be paid at the end of service. ${ }^{43}$

Generally, bounty amounts rose as the war dragged on, but with so many recruiters targeting San Francisco, an astute prospective soldier could play competing recruiters off against each other. Doing so was certainly not unethical, and as long as the individual did not desert, the military got its man in the end. Timing was everything in this game, and when the first calls came to raise the better part of two California regiments in late summer 1861, the patriotic excitement was sufficient to fill those

\footnotetext{
${ }^{42}$ Nelson and Onstad, 34-35.

43 Shelley, 2.
} 
companies relatively easily. Later in the war, however, the situation changed. In late 1862 there were three regiments competing for recruits in the San Francisco area, the $6^{\text {th }}$ California Infantry, $1^{\text {st }}$ California Cavalry, and what became the California Battalion of the $2^{\text {nd }}$ Massachusetts Cavalry. The result was that rival recruiting stations offered immediate cash bounties, between $\$ 25$ and \$100, as well as clothing, subsistence, and blankets (the latter two were offered by the cavalry commands). ${ }^{44}$ The cavalry commands, generally speaking, did not have to offer as much in actual cash payments since most men preferred service in the mounted arm, which had the somewhat inaccurate appeal of not having to spend the war in post, living a sedentary military life. ${ }^{45}$ The excitement of service was not the cavalry recruiter's only advantage over his foot-sore competitors. Since cavalrymen in the Department of the Pacific were required to supply their own mounts, much like the Confederate policy, but different than that employed by the Union cavalry in the East, they were compensated for their horses and their skills. While the volunteer infantryman private could expect to be paid in the low teens, cavalry privates were paid in the low thirties, with a substantial bounty. Men enlisting in the $1^{\text {st }}$ Oregon Cavalry received not only $\$ 100$ for enlisting, but also the ambiguous promise of a 160 acre land warrant (for somewhere in the vast state of Oregon) at the expiration of their service. ${ }^{46}$ The promise of money and land was an alluring combination, especially in Oregon, which suffered economic stagnation in the

${ }^{44}$ James McLean, 10. As McLean notes, the recruiters for the California Battalion accomplished their job despite the competition, in large part because they offered a guaranteed chance to serve in the East. Their presence, however, forced other recruiters to offer greater incentives.

${ }^{45}$ By the end of the war, both sides of this view proved too general, as infantrymen did patrol the immigrant roads and mining districts on occasion, and at the same time, the cavalry commands, though far more active in the field, did spend considerable time at the forts that served as their bases of operation.

${ }^{46}$ Victor, 132. 
late 1850s. Likewise, bounties would not have worked elsewhere in the Department of the Pacific, or, to a lesser degree, anywhere in the country for that matter, if economic conditions been better. For many who enlisted in the department's volunteer commands, the opportunity for wealth or good land that drew them to the Far West never materialized, and their misfortune became one of the recruiters' most effective tools.

Realizing patriotism and economic distress led men to consider joining the military and how recruiters manipulated those sentiments is only the first step in understanding the background and character of the men who served in the Department of the Pacific during the Civil War. In large part, they resembled their compatriots fighting in the main theatres of the war. However, there were some differences, and it is important to understand the influence those differences had on the volunteers who protected the Far West for the Union during the Civil War.

Passing a physical examination was the first step taken by all men who wished to become soldiers. According to Army regulations, doctors "examined him [the recruit] stripped; to see that he has free use of all limbs; that his chest is ample; that his hearing, vision, and speech are perfect." Furthermore, the doctors checked to see "he has no tumors, or ulcerated or extensively cicatrized legs, no rupture or chronic cuteaneous affection; that he has not received any contusions, or wound of the head, that may impair his faculties; that he is not a drunkard; is not subject to convulsions; and has no infectious disorders. ${ }^{\circledR 7}$ Rules, however, as the cliché goes, are meant to be broken. As a member of the $4^{\text {th }}$ United States Cavalry recalled:

47 Revised United States Army Regulations of 1861 cited in Don Rickey, Forty Miles a Day on Beans and Hay, (Norman, OK: University of Oklahoma Press, 1983), 31. 
Then I had to take off my boots and step under the apparatus used to measure the height of recruits and the sergeant proceeded to do his part of the work, and as he knew that the lieutenant [recruiting officer] wanted to enlist me, he stretched my measure considerably; bringing it up to five feet, five and one-half inches [the minimum height for cavalrymen]. Then he took me to the doctor's office. ... Apparently he had no intention of cheating Uncle Sam for the sake of getting a recruit. There was not a joint in my body that he did not examine thoroughly. ${ }^{48}$

Being otherwise fit, officials pushed the diminutive James Larson through the

bureaucracy and he officially entered the service of his country after his medical examination. ${ }^{49}$ Rules, already lax in 1860 when Larson enlisted, became even more so as the war dragged on. ${ }^{50}$

Although the physical standards for the troops were bent according to needs, department commanders and officials in both Washington D.C. and along the Pacific Coast, stood firm on the minimum qualifications for officers. Officials were less concerned about their physical attributes and ability to endure the rigors of service than their loyalty to the Union and their capacity to lead. ${ }^{51}$ In an effort to address those concerns, department commanders played a much more direct role in the selection of

48 James Larson, Sergeant Larson, (San Antonio, TX: Southern Literary Institute, 1935), 45-46.

49 Larson's slight, lithe form, was actually finely suited for light cavalry. Former Confederate general, Fitzhugh Lee, felt that young, light men, who, when fully equipped weighed roughly 200 pounds, were the best for cavalry service. Lee's comments can be found in George T. Dennison, Jr., Modern Cavalry, Its Organization, Armament, and Employment in War, (London: Thomas Bosworth, 1868), 354.

${ }^{50}$ Exceptions to this occurred when the California Battalion and California Hundred were raised for service in the East. During the initial call for recruits for the California Battalion, recruiters turned away roughly one fourth of all those who tried to enlist. Such was not the case facing recruiters raising troops for service in the Far West, as the lengths Colonel Steinberger went to in order to raise the $1^{\text {st }}$ Washington Territorial Infantry demonstrates. Parson, 20.

${ }^{51}$ With the shake up brought on by the war, Sumner and Wright did not hesitate to remove Regular Army officers if they questioned their ability to command. A civilian employee of the Quartermasters' office at Fort Vancouver explained to his mother that "Col. B.L. Beall in command of this District has been ordered to appear before a Board of Army officers for examination ... for the purpose of retiring such officers as are incompetent to perform Military duties.” Brigadier General Benjamin Alvord replaced Beall four months later. Alexander Caldwell Badger, "All in Fact ... Agrees with Me," 'Letters from Fort Vancouver,” edited by Dennis Defa, Idaho Yesterdays, 41 (1997) 2, 19. 
regimental officers than they were guaranteed under the volunteer system. Authority technically resided with the governor of each state or territory. Fortunately, Generals Sumner and Wright worked during the war with generally cooperative governors who heeded their advice during the selection process.

Even though the governors were generally cooperative, they were politicians and they lived in a world nowhere as neatly defined as the department commanders. California Governor John Downey tried to point out to General Sumner that he only varied from the general's suggestions "for the purpose of facilitating the prompt raising of the men and to prevent dissatisfaction on the part of the militia officers who are anxious to enter upon active service.”52 Downey's concerns, however, were not Sumner's problem; his objective was placing qualified and loyal officers at the head of the forming regiments. Sumner made his view plain when he informed the governor "I deem it very important that officers of the Army should be selected to command the regiments." ${ }^{53}$ Downey, like the other governors in the future, understood that Sumner (and later Wright) was the military expert, and that officers had the support of the War Department. One of the few showdowns over an appointment did not even involve the question of choosing between a Regular Army officers and a civilian, but rather that of which Regular officer to appoint colonel and commanding officer of the $2^{\text {nd }}$ California Cavalry. Downey wanted Lieutenant John Kellogg and Sumner desired that Captain A.J.

\footnotetext{
${ }^{52}$ O.R., 609.

53 Ibid, 587.
} 
Smith get the position. In the end the governor informed Sumner, “The regiments are now arranged as you desired."54

Sumner's broad authority to ensure the quality and loyalty of regimental officers also afforded Sumner the opportunity to grant advancement to men who served with and under him in the past. Roughly a dozen officers received high commissions, and a few others gained lesser positions, due to Sumner's prodding. Those who benefited included his son, and men like Lieutenant Benjamin Davis and William McCleave, a former first sergeant. In Davis' case, the general testified to his abilities, noting, "I have known this young officer since he entered the Army, and I know him to be one of the best officers in it," and just as important, he was "a firm loyalist to the Government." 55 As for former Sergeant McCleave, Sumner chose to replace an incompetent volunteer captain with McCleave, who was then living in Los Angeles. ${ }^{56}$ Since Sumner commanded the department when many of the California regiments first organized, his influence exceeded that of either General Wright or his replacement, Major General Irvin McDowell. Those officers who rose to high commands after Sumner's early attention included A.J. Smith, James Carleton, Patrick Connor, H.M. Judah, and B.F. Davis. The first three became generals (Smith served as a Union major general in the Deep South) and Davis was killed leading a cavalry brigade against the Army of Northern Virginia.

The situation was different in Oregon at the start of the war, where Governor Whiteaker made no effort to raise any troops and his loyalty to the Union was suspect.

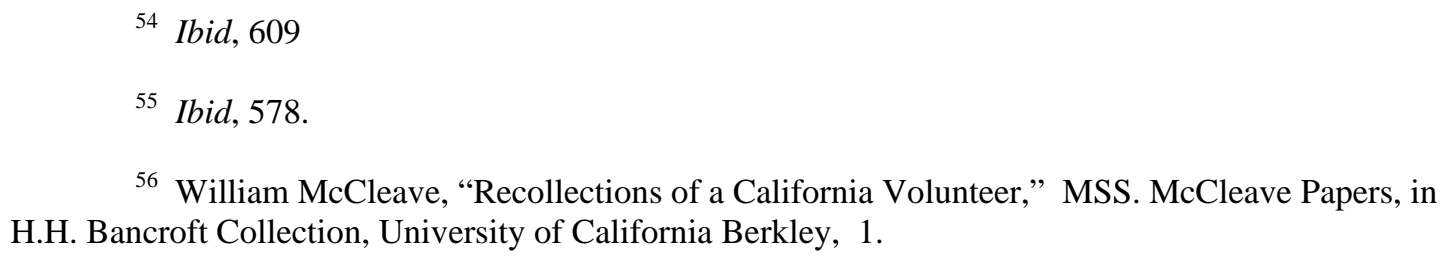
H.H. Bancroft Collection, University of California Berkley, 1. 
Given the governor's open criticism of the administration, the War Department made unique arrangements to encourage the raising of an Oregon cavalry regiment, and three years later, one of infantry. At the behest of Oregon Senator Edward Baker, the War Department granted civilians authority to recruit the $1^{\text {st }}$ Oregon Cavalry. Thomas R. Cornelius, a veteran of a number of the Oregon Indian wars directed the recruiting effort. Instead of reporting to General Sumner, his command was technically under the authority of Senator Baker, by then a colonel in the Army of the Potomac. ${ }^{57}$ This bizarre and unwieldy arrangement ended when Baker was killed at the October battle of Balls Bluff, Virginia.

Senators and generals were not the only ones making every effort to ensure the department's second tier officer corps was loyal and qualified. In September 1861, when rumors spread that James Denver (who gave his name to the city) wrangled for himself a generalship and assignment as a commander in the Department of the Pacific, California citizens opened a dogmatic campaign to prevent his appointment. Denver was an opportunist with an uncanny penchant for landing on his feet. Originally drawn to California by the Gold Rush in 1850, during the following eight years he served in a succession of political posts. Those offices included, state senator, secretary of state, and finally U.S. Congressman, and then in 1858 he left for a post in Kansas. In 1852 he had killed a newspaper editor, who criticized his handling of supply trains destined for California, in a duel. ${ }^{58}$ Whatever political capital he once had in California, his craven attempts to use the state as a springboard for his own gain combined with his affiliation

57 O.R., 633.

58 Ezra J. Warner, Generals in Blue, (Baton Rouge, LA and London: Louisiana State University Press, 1986), 120. 
with the Douglass Democrats sapped most of it by 1861 . When a letter he purportedly wrote to his brother, in which he took serious shots at the federal government, surfaced in a California newspaper, he became persona non grata. ${ }^{59}$

Unrest caused by the prospects of California volunteers being led by Denver became both widespread and virulent. The situation caused so much anxiety that California’s Adjutant General, William Kibbe, warned the War Department, "We are endeavoring to fill up the six regiments called for from this State, and I assure you that this report [that Denver had been posted to the department] has proved our greatest obstacle. ${ }^{\circ 0}$ Kibbe summed up the situation by stating:

All true Union men in this State ... who have manifested their patriotism and loyalty by volunteering their services for the war. ... openly declare that if General Denver assumes the command over them they will at once resign; that they have not only no confidence in his loyalty, but on the contrary they believe him to be at least a sympathizer with the rebel cause and opposed to the war, and also that he is totally unfit in point of military skill or experience. ${ }^{61}$

The War Department heeded the warning and Denver spent the bulk of his war experience in the military as a desk general before resigning on March 5, $1863 .{ }^{62}$

In an odd sense, becoming a junior officer seemed, on the surface, more difficult than gaining regimental rank, or a general's commission (even if held only briefly). Since the troops themselves decided who became company officers, with the final approval of the governors who could refuse to appoint any selected man, both the department high command and the political leaders understood the importance of

59 The California Adjutant General, who sent a lengthy letter and a number of enclosures, did not indicate which paper printed Denver's letter. O.R., 608.
${ }^{60}$ Ibid.
${ }^{61}$ Ibid, 607.
62 Warner, Generals in Blue, 120. 
ensuring those officers met at least a minimum level of competence. ${ }^{63}$ Therefore, those chosen by the troops still had to pass a qualifying examination, designed, in theory, to ensure their fitness for command, and more importantly, their loyalty to the federal government.

The tests were conducted by Regular Army officers at one of the permanent installations, such as department headquarters in San Francisco. Volunteers in the District of Oregon, such as the $1^{\text {st }}$ Oregon Cavalry’s Captain John Drake, went before a board of examiners at Fort Vancouver. ${ }^{64}$ Any officer who failed the examination was denied a commission. The board of examiners, however, proved less efficient than their stated objective. Captain Drake admitted that outside the regiment's colonels, Thomas Cornelius and Reuben F. Maury, "the rest of us officers knew absolutely nothing about military matters.” In fact, Drake and the other junior officers discovered “There was a man in Company D who had been a private soldier in the regular army. We (the officers) got him into our cabin and he taught us the manual of arms. There was another man in the same company who had been in the cavalry service in British India. He taught us the sabre exercise.” ${ }^{65}$ The boards, however, were not really concerned about the junior officers’ inexperience; they were volunteer regiments after all. They achieved their primary goals, namely of not letting Confederate sympathizers get into the officer corps where they could foment rebellion.

${ }^{63}$ O.R., 603. As California Governor Downey noted in public proclamation cited on the aforementioned $O . R$. page, technically governors appointed all officers, but nearly every governor deferred to the troops at the company level. To do otherwise was impractical -there were too many positions to be filled -and it also undermined recruitment efforts, as commissions were granted to recruiters with the idea that once they raised a company they (the recruiters) would serve as that unit's officer.

${ }^{64}$ John Drake, “The Oregon Cavalry,” Oregon Historical Quarterly, 65 (1964) 4, 396.

${ }^{65}$ Ibid, 396. 
Had a small number of strategically placed secessionists been able to obtain commissions in the Department of the Pacific's officer corps, Union control of the region might have been jeopardized, but the measures taken by the military rendered such a notion impractical. The officer corps, however, was not the only way to sow the seeds for a coup d'etat, or so at least many prominent citizens feared. Citizens in Eugene, Oregon, fearing Confederates sympathizers might infiltrate volunteer units, beseeched the military high command to take steps to prevent that from occurring. In an effort to calm such fears, General Sumner's office informed these town leaders that District of Oregon commander, Colonel B. L. Beall, had been instructed, “under no circumstances to accept the services of anyone 'about whose loyalty to the National Government there is the shadow of a doubt,"” which Sumner explained, "will frustrate any plans on the part of the secessionists to place their friends in positions dangerous to the State.”66 The general was more sanguine when he wrote to Colonel Beall that he had "reason to fear that in the event of volunteers being called for from the State of Oregon," that at least "the officers selected may not possess that character for loyalty to the General Government essentially necessary." ${ }^{67}$ Although no internal threats from either the officers or the troops ever materialized, Sumner was correct to be wary at the war's outset. As evidence that the watchful eyes and screening process failed occasionally, a member of the $1^{\text {st }}$ Oregon Infantry described how upon hearing the news of President Lincoln's assassination, "a few were heard to rejoice over the dreadful deed and not all such rejoicing was confined
${ }^{66}$ O.R., 599.
${ }^{67}$ Ibid, 598. 
to the civilians - one Commissioned officer, at least, having been reported as a Rebel sympathizer.",68

With each new ore discovery the transient population of miners spread further throughout the region and by the onset of the Civil War, the thinly populated Far West boasted the most diverse residents in the nation. Not only were there persons from every state, western Europe, and Russia, but also China, a large Hispanic population, which until 1848 had been citizens of the Republic of Mexico, and of course the dwindling number of Native Americans. Since the people came from such diverse geographic and national backgrounds, concerns over the population's allegiance to the Union were legitimate. Therefore, a key to discerning the role played by the troops in the Department of the Pacific during the Civil War is understanding the background of the men who served in it.

Like the population they protected, the men who served in the Department of the Pacific came from an amazingly diverse geographic background and worked in an equally wide array of jobs. For many citizens, life on the Pacific coast never quite reached the economic success that led them to come to those far off lands in the first place. Farming was not easy and the reality of placer mining was not the El Dorado image shamelessly promoted in the East and across the seas. As it turned out, mining miners was the best work to be found. Thus, when a need for recruits to fill regiments during the war arose, there was a ready pool of potential volunteers.

In contrast to what had been true in the prewar army, American citizens actually outnumbered foreigners in the ranks of the far western regiments. In the case of the

${ }^{68}$ Shelley, 4. 
Oregon regiments, this is somewhat surprising, considering, the fact that the region had not been under American control for very long. As a result few of the men who volunteered were actually native Oregonians. The $1^{\text {st }}$ Oregon Cavalry’s William Clyde and Charles Hubbard were two of the rare exceptions. ${ }^{69}$ Among the troops recruited in Oregon, the largest number named the Old Northwest as their place of birth, with Pennsylvania and New York not far behind. ${ }^{70}$ Troops from every Confederate state except Florida and Mississippi also served in the Oregon regiments. Even though American citizens made up a majority of the troops in the department, there were significant numbers of foreigners in the ranks. The foreign-born troops came from such countries as Norway, Switzerland, England, France, Scotland, and more frequently, Germany. The largest number of foreigners, however, came from the Emerald Isle, which, given the general influx of Irish immigrants after the potato famine, is not surprising at all. ${ }^{71}$

The men in the California regiments generally mirrored their compatriots to the north, with one significant and one minor exception. Whereas few men serving in the Department of the Pacific were born in the region, one command was an exception to the rule. As a captain in the $1^{\text {st }}$ California Infantry wrote, “The extraordinary horsemanship displayed by the native [Hispanic] Californians led to the belief that a battalion of

69 M.A. Pekar, and Edna Mingus, compilers, Oregon Soldiers During the Civil War, (Portland, OR: Genealogical Forum of Portland, Inc., 1961). There are no page numbers in this work, but entries are arranged alphabetically. This compilation deals strictly with troops who served in the Oregon regiments or the $1^{\text {st }}$ Washington Infantry Regiment not raised in California. See listings under Clyde and Hubbard.

70 These determination are based on a compilation of the origins of the men listed in Pekar and Mingus.

71 Pekar and Mingus. 


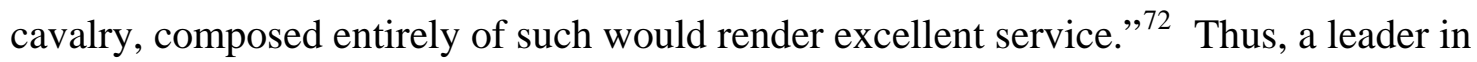
the Hispanic community in southern California named Don Andreas Pico helped raise a battalion made up primarily of Hispanics from the Los Angeles region. The command was eventually named the First Battalion of Native Cavalry. Despite Pico’s important role in raising such a force from among the native Californians, age and disability kept him from taking to the field; as a result, Major Salvador Vallejo served as the battalion's original commander. Both men were prominent in the local Hispanic community, which at that time retained much of its pre American acquisition dominance -although mostly confined to the southern part of the state. ${ }^{73}$

Although an entire battalion was raised in California’s Hispanic communities, these were not the only non-Caucasians who served in the Department of the Pacific during the war. Charles Graffell, an African-American cook, served in the $2^{\text {nd }}$ California Cavalry. ${ }^{74}$ There is some evidence that other African-Americans held similar positions, but they appear to have been limited to auxiliary roles. Taken as a whole, the men in the ranks in the Department of the Pacific came from a more cosmopolitan background than any other command in the Union armies.

Unlike their geographic, national, and ethnic backgrounds, which differed widely, the men serving in the Department of the Pacific were similar in their ages, but older than those serving in the East. Of course there were wide variances among the troops, such as

72 Richard Orton, Records of California Men in the War of the Rebellion, 1861-1867, (Detroit, MI: Gale Research Company, 1979), 304.

73 Ibid, 304-320.

74 Charles Graffnell Papers, United States Military History Institute, Carlisle Barracks, Pennsylvania. Graffnell's petition for a government pension, and an obituary, are included in this small collection. 
Privates Richard Jordan (42), Chancy Gregg (45), and Erwin Fleeheart (20), all from the $4^{\text {th }}$ California Infantry Regiment, but most soldiers were in their late twenties. ${ }^{75}$ Being near thirty was hardly young for military service and it was noticeably older than an 1862 survey of the men in the main Union armies, which found 25 to be the mean age. ${ }^{76}$ This is not surprising given that the majority of the region's population came from elsewhere and therefore had already spent time trying to make their way in the world.

The hope of becoming wealthy or at least economically independent proved an illusion for most, and, as a result, men too poor to return to the East worked in many fields to earn their living. Finding work outside farming and mining in the sparselypopulated Far West was difficult. In fact, in the search for economic stability many men had a varied, almost wandering working history before they joined one of the fifteen regiments or battalions that served in the Far West. Many, like the $1^{\text {st }}$ Oregon Infantry's Corporal Hilleary spent the years immediately before the war in a number of odd jobs. In Hilleary's case those jobs included mining for many years and, finally, before joining on Christmas Eve 1864, working as a public school teacher. ${ }^{77}$ Sergeant George Hand, a 31 year old bachelor from New York, was one of the true "49ers" who fell victim to "the California fever," which "was raging at the time and, as I had not been vaccinated against it, I took it and left for [by sea] for the land of gold.” Hand left behind the early stages of a career in drafting and twelve years later abandoned his pursuit of gold, no better off for

${ }^{75}$ Royal Bensell, All Quiet on the Yamhill: The Civil War in Oregon, edited by Gunter Barth, (Eugene, OR: University of Oregon Press, 1959), xiv, 217-219.

\footnotetext{
${ }^{76}$ Ibid, xiv.

${ }^{77}$ Nelson and Onstad, 25-28.
} 
his efforts. ${ }^{78}$ The $4^{\text {th }}$ California Infantry's Royal Bensell tried the other common occupation, farming, which met with little success before he joined in $1862 .{ }^{79}$

The story was the same for most soldiers. Few boasted steady (successful) employment histories before joining. Although farmers, miners, and general laborers were the most common pre-war occupations, the regimental rosters included carpenters, blacksmiths, a banker, accountant, silversmith, and even a painter. ${ }^{80}$ Also, among the Oregon troops was a home guard unit mustered into the $1^{\text {st }}$ Oregon Infantry comprised of students from a private academy and Pacific University. ${ }^{81}$ One of the most industrious individuals was J. Henry Brown, who by 1862 had already spent ten marginal years chasing gold around the Far West. Determined to better himself, and his economic chances, he wanted to attend an academy in Salem, Oregon, but he had no money for food, board, or tuition. Undeterred, Brown "wait[ed] on the tables in a hotel for my board, and sawed wood nights, morning and Saturday for my clothing and tuition.” However, after six months "it became evident that the toil was too much and I was compelled to discontinue [it].” The hard-working 24-year-old, originally from Illinois, joined the $1^{\text {st }}$ Oregon Cavalry when the call for recruits came in $1861 .^{82}$

Despite their significantly lower numbers and the theoretical impact of the examination boards, the background of the officer corps was also quite diverse. Captain

\footnotetext{
${ }^{78}$ Carmony, 8.

${ }^{79}$ Bensell, 187-192

${ }^{80}$ Compiled from a search of Pekar and Minugs.

${ }^{81}$ Cyrus H. Walker, "Why the First Oregon Volunteer Infantry was Organized,” MSS, Oregon

${ }^{82}$ Source for this entire paragraph is, J.[oseph] Henry Brown, “The Autobiography of J. Henry Brown,” MSS. Bancroft Collection, University of California -Berkeley, Berkeley, California, 47-48.
} Historical Society, Portland, Oregon, 2. 
Drake of the $1^{\text {st }}$ Oregon Cavalry, recalled that the regiment's officers included "three farmers, two miners, two lawyers, two doctors, four clerks, one civil engineer, one mechanic, five businessmen, two former soldiers of the United States Army, four of no particular vocation.” ${ }^{83}$ The other commands also included men from a wide range of backgrounds. Among the $1^{\text {st }}$ California Infantry's company officers were a number of printers. In fact, Sacramento printers made up the vast majority of Company B. ${ }^{84}$ As Captain Drake noted, there were a good number of former soldiers, mostly noncommissioned officers, sprinkled throughout the officer corps of the various commands in the Department of the Pacific. That fact was a boon to newly-appointed field grade officers, who relied on the experienced old soldiers to lead and train the raw volunteers. ${ }^{85}$

Just as the men differed in occupation and place of origin, their quality as soldiers, and really as human beings, differed as well. On the whole, the majority of both officers and men eventually learned the soldier's trade sufficiently to carry out the department's various responsibilities. Individually, however, there were martinets and ne'er-do-wells among the officers and cutthroats and bums among the men, and both groups had their share of drunks.

Drunkenness plagued the frontier military and that situation did not abate because of the war -in any department or in either army. ${ }^{86}$ Service in the vast department, with

${ }^{83}$ Drake, 395.

${ }^{84}$ Pettis, 7-8.

${ }^{85}$ As was the case in both the Union and Confederacy, former Regular Army officers were highly sought for their ability to organize and train both raw recruits, and the many equally raw politicians who wiggled commands out of politically driven state and national leaders. In such an atmosphere relegating an experienced officer to a junior commission made no sense.

${ }^{86}$ Perhaps the most famous example of alcoholism among $19^{\text {th }}$ Century officers was U.S. Grant, who used alcohol to fight the boredom of garrisoning a lonely outpost. Likewise, during the Civil War, 
posts from the almost unbearably hot Fort Yuma, the dampness of the installations on Alcatraz Island, in San Francisco harbor and on Vancouver Island, Washington Territory to the remoteness of Forts Colville near the Canadian border and Fort Lapwai in what is now west-central Idaho easily corroded the best soldiers, and only exacerbated the worst traits in the poorer ones. Drunkenness was not the only problem among the troops, but it was the most destructive, as it only enhanced other detrimental traits. Given the day in and day out monotony faced by those troops manning permanent installations, or the exhausting effect of extended patrols over inhospitable lands, many troops took any opportunity to escape their routine with a few drinks. As one member of the $4^{\text {th }}$ California Infantry recalled, pay day meant drinking. The drinking commenced shortly after he and his comrades received their first payment as soldiers. The result was not surprising; "It looked as if a hard battle had been fought; for more than a mile around the camp there could have been seen those who had fallen dead-drunk, the victims of General Alcohol.. ${ }^{87}$ The truth was that, excessive drinking did far more than diminish military effectiveness; it was dangerous in and of itself. J. Henry Brown recalled one such incident that occurred when heading to Fort Walla Walla, where "a member of Co. "C" who was drunk and a bad man anyhow shot a[nother] member of Co. "C" while on the march.,"88

accusations of drunkenness during combat were all too common. One of the worst cases was that of Brigadier Generals Edward Ferrero and James Ledlie, who sat in their bomb proof and got drunk while their divisions floundered at the July 30, 1864 Battle of the Crater around Petersburg, Virginia. Warner, Generals in Blue, 151, 277.

${ }^{87}$ Edward Carlson, “Martial Experiences of the California Volunteers," Overland Monthly, 7 (1886), 482.

${ }^{88}$ Brown, MSS, 48. 
While dealing with one drunk soldier could be deadly, such a situation became exponentially more explosive when confronted with numerous drunken soldiers, as became clear to a member of Company E $11^{\text {th }}$ Ohio Cavalry, then guarding the telegraph line to San Francisco. After most of the company went on a binge, "they were nearly all drunk. One of them was so drunk that he could not get on his horse." When ordered to do so, he attacked a sergeant, who "drew his revolver and shot him, the ball tore out one of his eyes but he did not kill him.” At the same time, after another drunk soldier rode about the post, knocking down an officer in the process, “The commander ordered Companies [A, B,] D. and G. under arms.” ${ }^{89}$ In the melee that ensued, the soldier on the horse was mortally wounded. Such incidents did nothing either for morale or efficiency. Drunkenness impeded control over troops and destroyed the cohesion necessary in military units.

Not every soldier drank and even those that did were not all necessarily drunks; more than a few soldiers were simply unsavory by nature. Sergeant John Dimick felt many of his fellow troopers were "Mean low degraded wretches that cant talk of anything but some low blackguard slang. And it would be like jumping out of Hell into heaven to get away from them.”90 Just as offensive, and potentially far more deadly, than merely being a despicable individual was having cowards among the soldiers, and somehow such individuals found their way into the ranks. Royal Bensell served with such an individual

${ }^{89}$ Hervey Johnson, Tending the Talking Wire, edited by William E. Unrau, (Salt Lake City, UT: University of Utah Press, 1990), 103.

${ }^{90}$ Allan Kittel, general editor, Bear Bravely On: Letters from Sergeant John Buel Dimick, First Oregon Volunteer Cavalry to Almira Eberhard, 1862-1865, (Portland, OR: Lewis and Clark College, 1983), F5. This work is paginated in the unique letter plus number format. 
noting, "My impression is, J.B. Condon is unnecessarily frightened, in more polite terms, a Coward."91

As they were quick to point out, the officers could be at least as repugnant as any soldier. Common complaints centered on abuse of power (one such incident prompted a California infantryman to express a sentiment that reverberates among all soldiers across time; he ridiculed his commanding officer as "What an Ass."), which only got worse when the officers drank. ${ }^{92}$ Demonstrating a lack of decorum as well as the ability to control their drinking, a California soldier wrote in his diary that "Lieut. of $5^{\text {th }}$

[California] Inft. went on dress parade very drunk," while “Another one was caught in the graveyard with a squaw.” Not surprisingly, the sergeant felt the officers "are, take them all in all, a miserable, slovenly set and altogether unfit to command even Indians. This is the whole and nothing but the truth."93

Concerned more with the martial abilities, or rather the lack of those skills, than the character of his fellow officers, Captain Drake worried about the almost total lack of military knowledge he and his fellow $1^{\text {st }}$ Oregon Cavalry officers possessed: “This was discussed amongst us: how we were to obtain the necessary instruction to enable us to perform the duties of officers and train those raw recruits was a problem that worried us not a little." $94 \quad$ By the end of the war, Drake, with more than a bit of introspection, could say, "Notwithstanding the difficulties under which we labored, the time came when
91 Bensell, 45.
92 Ibid, 85.
93 Carmony, 38-39.
94 Drake, 396. 
we understood our business and our duties as well as any officers or troops that we came in contact with, and a great deal better than many of them." 95

As the records show, Drake and his associates eventually became efficient officers, and most of the men also became good soldiers. Despite the number of examples of the worst of both men and officers, the majority did their duty to the best of their abilities and more or less reflected the values of the population from which they came. Even those who disdained the worst in their fellow soldiers recognized that most were good men and good soldiers. Sergeant Dimick, who despised many of his fellow cavalrymen, realized they were a mixed bag. As he informed his fiancé, "It is true there is [sic]a good many men in our company that I would not be ashamed to be in company with. But there are some again that are no account to themselves or to anybody else." ${ }^{96}$ The always pragmatic Captain Drake felt his troops, no matter their faults, "were fine material for frontier soldiers, accustomed to the use of firearms and the care of horses; notwithstanding their inferior number the huge task of keeping things straight in that vast extent of wilderness and desert was faithfully and efficiently performed.”97 Colonel George Bowie added the compliment that "They all faithfully and honorably acquitted themselves in the sphere assigned them.”98

The men who served in the Department of the Pacific during the Civil War came from all walks of life and their places of birth spread across North America, including every state, Canada, and Mexico, and across the Atlantic to Europe. Virtually all of them
${ }^{95}$ Ibid, 397.
${ }^{96}$ Kittell, F5.
${ }^{97}$ Drake, 399-400.
98 Bowie, 6. 
were volunteers and most started out as neophytes. Understanding who served in the nation's western most lands during the Civil War provides a basis on which to examine their service to their (in some cases adopted) country. Knowing their demographic information, pre war employment, how they characterized each other and their service rendered, sheds light on the type of soldiers that served in the Department of the Pacific during the Civil War. Being aware of such important information makes it clear why the regional and national officials and military high command initiated policies toward the troops. Despite the inability to gain any glory in the Far West, astoundingly diverse men from different regional, national and ethnic, as well as economic, backgrounds successfully carried out the complex responsibilities assigned them during the war. 


\section{Chapter \\ - 3 -}

\section{THE DANGER WITHIN: PROTECTING THE FAR WEST FROM SOUTHERN SYMPATHIZERS}

When war broke out in the East, the Federal government knew the Far West was

not secure. Not only were there thousands of southern-born civilians spread throughout the region, the department's officer corps was rife with southerners, including the department head. Although Albert Sidney Johnston did not dishonor his commission by turning over his command to southern sympathizers, rumors that he would reached Washington D.C. even before the firing on Fort Sumter. ${ }^{1}$ By secretly ordering the unquestionably loyal Edwin Sumner to San Francisco to replace Johnston, officials in the capital made it clear that they feared an insurrection in the Far West and that they were committed to preventing that from occurring. ${ }^{2}$

Once the war began the Federal government worried that pro Confederate insurgents would precipitate a revolt within the department's borders, either on their own or with the aid of invading Confederate forces. If such a revolt proved successful it would be an economic disaster for the Union and a political and military boon for the

${ }^{1}$ Unlike General Twiggs, who surrendered the Department of Texas to Texas forces, there was no organized body of semi official Confederates for Johnston to turn the department over to, even if that had been something he considered. Colonel Erasmus Keyes, General of the Army Winfield Scott's secretary, wrote that in late March 1861 Oregon Senator James Nesmith reported rumors that Johnston was a secessionist. Not wanting another Twiggs-like fiasco on their hands, orders removing Johnston were issued the next day. Erasmus D. Keyes, Fifty Years' Observation of Men and Events, (New York: Charles Scribner's Sons, 1884), 420-21.

${ }^{2}$ Writing about Sumner's arrival in San Francisco almost twenty years after the end of the war, General William T. Sherman stated, "We all agree that Gen. E.V. Sumner was as true a man and perfect a solider as this generation has produced, and that he saved our country and California from the dangers and conflicts which were imminent in 1861 by the betrayal of his high trust there by his processor, Albert Sidney Johnston, a la Twiggs in Texas." The characterization of Sumner was accurate, but Sherman, like so many of his contemporaries, was entirely wrong about Johnston. New York Times, November 14, 1884. 
Confederacy. Ensuring that did not happen was the Department of Pacific’s most important task -especially at the outset of the war. Although the general view was that the strongest concentration of Confederates and southern sympathizers was in southern California, the reality was far more challenging. When the world flooded into California in 1849 and then later dispersed in spasmodic rushes to other gold strikes throughout the Far West, thousands of southerners were among the faceless miners desperately pursuing the dream of quick riches. With pockets of southerners, many of whom openly sympathized with their native states, scattered throughout California and Oregon as well as Washington and Nevada territories, the Department of Pacific had to maintain close watch for any insurgent activities, and be prepared to defuse those threats, if possible, and, if not, to suppress them by force.

Oddly, the man the Federal government distrusted, department commander Albert Sidney Johnston, actually initiated the first measures to protect the Pacific slope from internal threats. It is significant to note that as early as December 1860, the government developed apprehensions about the Far West's security, specifically about retaining the region within the union. Such concerns were not misplaced, given the vocal secessionist populace and large number of southerners stationed throughout the region's military posts. Understanding the atmosphere, with regard to southern sympathizers, is therefore fundamental to understanding how the department protected the Far West from a proConfederate insurrection.

Well before the war, there had been an element among the western frontier populace agitating to break away from Union control and to create their own nation. The issue revolved around not wanting to abide by federal laws (including taxes) crafted by a 
government a continent away. The would-be revolutionaries hoped to create a new nation on the North American continent, a Pacific Republic. This was not a new scheme. The original idea was called the Bear Flag movement, which referred to the uprising led by famed American frontier explorer John C. Fremont against the Mexican government that took place in Sonoma, California, in June 1846, during the Mexican-American war.

After the 1860 election California agitators dusted off the dream of a Pacific Republic and used the Bear Flag as a means to challenge the federal government without being directly associated with the Confederacy. Their hope was that Department of the Pacific commander General Johnston would collude with such a scheme by turning over his command to those attempting to take the Far West out of the union. ${ }^{3}$ Despite rumors to the contrary, and fears at the highest political and military levels in Washington D.C., the general flatly rebuffed those plotters who had the temerity to approach him with their plan. Although they could not know Johnston would not betray his commission, as David Twiggs had, officials in the nation's capital had nothing to fear.

Uneasiness about the security of the most remote section of the nation grew as the political unrest intensified with the secession of southern states in late 1860 and early 1861. Making matters seem far more precarious, the incoming Lincoln administration understood that significantly more people in the states of California and Oregon had voted against, rather than for, Abraham Lincoln the previous November. ${ }^{4}$ Lincoln won

${ }^{3}$ As Charles Roland pointed out in his biography of Johnston, the general's southern origins and his having been a slave owner in the past spawned rumors that he planned to hand the department over to secessionist schemers as war approached. So prevalent were those rumors that Governor Downey asked the general for assurances that he would not dishonor his post; Johnston strongly denied any role in such a scheme. Charles Roland, Albert Sidney Johnston: Soldier of Three Republics, (Austin, TX: University of Texas Press, 1964), 244-46.

${ }^{4}$ G. Thomas Edwards, "Holding the Far West for the Union: The Army in 1861," Civil War History (1968) 14: 307-308. 
California by a mere 711 votes and Oregon by 280, and those thin margins were only possible because of the split Democratic ticket. ${ }^{5}$ Such an atmosphere did not portend good things for the Union in the Far West. In January, in response to those trepidations, Army headquarters ordered Johnston to strengthen the San Francisco harbor defenses against all enemies. ${ }^{6}$ Johnston quickly took steps to allay those concerns, including countermanding Army headquarter orders to discontinue work on Fort Point at the harbor entrance, manning that post in force, giving specific instructions heightening the level of awareness at the harbor installations, and removing 10,000 rifled muskets from Benicia Barracks to the greater safety at Alcatraz Island. ${ }^{7}$ Making it clear that the danger could come from any source, Johnston ordered the commander on Alcatraz Island, “To maintain your post and defend Alcatraz Island against all efforts to seize it, from whatever direction such efforts may be made.” ${ }^{\prime 8}$ Although maligned by contemporaries as a would-be traitor, whose plan to turn the department over to secessionist was thwarted only by the timely arrival of his replacement, the general not only brusquely spurned inducements to surrender his command, he diligently followed orders until he turned command over to his successor. Therefore, it was Johnston who set in motion the strengthening of the San Francisco harbor defenses against any dangers, including insurrection.

${ }^{5}$ Alvin M. Josephy, The Civil War in the American West, (New York: Knopf, 1991), 233.

${ }^{6}$ War of the Rebellion: Official Records of the Union and Confederate Armies, series 1 (Washington D.C.: Government Printing Office, 1897), 50:1, 434.

${ }^{7}$ Ibid, 443-444, 446-448, 450.

${ }^{8}$ Ibid, 448. 
The efforts to reinforce San Francisco harbor may have relieved some anxieties about that important trading hub, but it did not quell the increasingly vocal calls for a separation from the union. What the new commander, Edwin Sumner, found after corresponding with his subordinates and civilian informants did not alarm the veteran officer so much as it left him and officials in the capital ill at ease. As part of the initial assessment of his new command, Sumner informed Army headquarters that despite a generally loyal populace, subversive efforts were afoot "to draw California into the secession movement; in the first place as the "Republic of the Pacific" expecting afterwards to induce her to join the Southern Confederacy." ${ }^{9}$ Not long after the War Department received that sobering view, the New York Times opined for its readers that southern sympathizers in California "hoped that by suddenly precipitating the state into confusion and proclaiming a Pacific Republic, either the whole of the state or, at all events, the Southern half of it, would gently but surely glide into their hands." ${ }^{10}$ Echoing these sentiments, Mary Rhodes, who lived in southern California, wrote "The only hope of peace here is the formation of a Pacific Republic." ${ }^{11}$

It seemed that the Pacific Republic movement was on the verge of coming back to life, and along with it the Bear Flag. In mid 1860 one central Californian echoed the Pacific Republic sentiment when he warned his eastern relatives,

Whenever you get at it and divide North and South on your side of the mountains we shall secede, with the Rocky Mountains for a line and form an Empire on the Pacific, with Washington Territory, Oregon and California and we shall annex all

\footnotetext{
${ }^{9}$ O.R. 50:1, 472.

10 New York Times, May 23, 1861.

${ }^{11}$ Rhodes, cited in Laurence Fletcher Talbott, "California Secessionist Support of the Southern Confederacy: 1861-1865, (Doctoral dissertation, The Union Institute, 1995), 120.
} 
of this side of Mexico. We should have a fine country. We don't care a straw whether you dissolve the Union or not. ${ }^{12}$

Although recent scholars have questioned whether or not southern California was a hotbed of pro-Confederate sentiments, that was the belief held during the war. This was not a view held by a gaggle of fearful post commanders in remote districts and paranoid civilians. Future general James Carleton and Winfield S. Hancock both believed enemies of the federal government populated the southern part of the state. ${ }^{13}$

In mid 1861 Hancock served as an assistant quartermaster in Los Angeles. Being stationed deep in the southern part of the state, the captain diligently kept tabs on any disloyal activities. On May 7 he sent a warning to departmental headquarters, informing Sumner that the Bear Flag had been publicly raised 12 miles from Los Angeles three days earlier and that informants told him "that flag will be paraded through our streets under a strong escort" the next week. ${ }^{14}$ He felt that in order "to avoid insult to our flag, it might be well to have all the efficient dragoons from Fort Tejon at this point by Saturday next.”15 Although the dragoons did not reach the town before the rumored demonstration, Sumner already had the foresight to order a company commanded by Brevet Major James Carleton to Los Angeles. When the rumored parading did not occur Hancock subscribed the inaction to two things: first, he believed the "leaders" to be men

12 Katherine A. White, compiler, A Yankee Trader in the Gold Rush: The Letters of Franklin A. Buck, (Boston and New York: Houghton Mifflin Company, 1930), 182-183.

${ }^{13}$ For examples of Hancock and Carleton's warnings about secessionist threats in southern California see O.R., 50:1, 477, 479-80, 482-84, 549-49, and 555.

14 O.R., 50:1, 481; several decades later one participant told an historian "There were about 200 of us, and we carried the Bear Flag. We marched around Jonathan Tibbetts' house in the moon light, as we wanted to give him a scare .... We knew he was giving information to the government." "Tooch” Martin quoted in, Percival J. Cooney, "Southern California in Civil War Days," Historical Society of Southern California, 13 (1924) 1, 59.

15 O.R., 50:1, 481. 
of means, who suddenly realized their attempts to foment anti government sentiment among the masses might endanger their wealth, and secondly, "the moral effect produced by the reported proximity of troops," extinguished their enthusiasm. ${ }^{16}$

Unfortunately for the Department of the Pacific and the federal government, talk of splitting the West from the union and forming a Pacific Republic not only persisted, but extended beyond California. The idea of a separate nation on the Pacific slope had been kicked around in Oregon almost as long as it had in California. For almost twenty years there were Oregonians who felt no particular connection to a national government that seemed little interested in their well-being, periodically calling for a Pacific Republic. In July 1860 one Oregon newspaper charged that southern-sympathizing Oregon senator Joe Lane and like-minded California senator William Gwin were conspiring with southern leaders to break the nation into three separate republics, two in the East and one on the Pacific Coast. ${ }^{17}$ Farther up the coast, one Puget Sound pioneer remembered "there was in serious contemplation establishment of an American republic on this Coast independent of the United States to embrace all the States and Territories west of the Rocky Mountains."18

Although the notion of a Pacific Republic originated long before the Civil War, the idea gained renewed appeal in the unsettled political atmosphere caused by the war. In this atmosphere, Department of the Pacific officials faced the challenge of trying to control a divided population, where secessionist sentiments - which often gave rise to

\footnotetext{
${ }^{16}$ Ibid, 483.

${ }^{17}$ Roger Van Winkle, “A Crisis in Obscurity: A Study of Pro-Southern Activities in Oregon, 1854-1865.” (Master’s thesis, Western Washington University, 1968), 453-455. 1969), 51.

${ }^{18}$ Charles Prosch, Reminiscences of Washington Territory, (Fairflied, WA: YE Galleon Press,
} 
renewed calls for a Pacific Republic - were found in every town and mining camp. As a pioneer Angelino remembered, “Sympathy was very general here for the Confederate cause."19

Across the Sierras in Nevada Territory, secessionist sentiment grew so vocal and displays of southern support so frequent by early summer 1861 that reinforcements were rushed to Fort Churchill, 30 miles south of the capital, and a supply of arms stored in Carson City were removed to a safer location. ${ }^{20}$ A homegrown Confederate flag was even flown in Virginia City until the arrival of a Union force intimidated the secessionists. $^{21}$ The captain sent to investigate the level of danger concluded that there existed "an organization to subvert the authority of the Federal Government in this Territory and declare for the Confederate states.”22

The story was no different in the western part of Washington Territory: “At an early stage in the great civil war it became apparent that there were in California, Oregon and Washington, men ready to aid in the destruction of the Union by every means within their power.”23 Puget Sound pioneer Charles Prosch further stated, “In secret they plotted, here and elsewhere on the coast, to dismember the Union, with a view of aiding

19 Harris Newmark, Sixty Years in Southern California, 1853-1913, edited by Maurice and Marco Newmark, (Boston and New York: Houghton Mifflin Company 1930), 311.

${ }^{20}$ Robert W. Frazer, Forts of the West, (Norman, OK: University of Oklahoma Press, 1972), 92.

21 O.R., 50:1, 499-501, 505.

22 Ibid, 510.

23 Prosch, 51. 
their confederates in the Southern states." ${ }^{24}$ The situation was the same in the territory’s eastern half.

Prior to the war, Walla Walla, which was adjacent to Fort Walla Walla, was the only town of any note in the eastern part of Washington Territory until a gold strike on Idaho's Salmon River in 1863. At that time it was also the only gathering of buildings worthy of being called a town in a region that included northeastern Oregon and what became west-central Idaho Territory in 1863. As an established town, Walla Walla served as the gold miners' main supply hub, and as such it grew in the same way that gold rush towns had grown in the Sierra Nevadas. There were large numbers of southerners included in the population of desperate miners. When war broke out in the East, the proximity of U.S. soldiers and southern sympathizing miners led to the inevitable clash. As one early town resident remembered, "The gamblers and roughs at Walla Walla and all the mining camps were Rebels or rebel sympathizers .... And these gamblers and desperadoes were the terror of the Union people.” In such an atmosphere tensions escalated when soldiers came to visit one of the many bars. The southernsympathizers "sometimes would make a soldier or volunteer drink to the health of Jeff Davis or Beauregard, and if he refused, kick him or knock him down.,25

In the fall of 1861 words finally exploded into gunfire during a ball honoring a local girl. As the mixed crowd grew rowdy, words were exchanged between one of the soldiers and the southern gamblers, two of whom pulled out their pistols and began firing. During the ensuing melee some 50 to 100 persons emptied their weapons, some "jumped

24 Ibid.

25 Doyce Nunis, editor, The Golden Frontier: The Recollections of Herman Francis Reinhart, 1851-1869, (Austin, TX: University of Texas Press, 1962), 204-05. 
down from the gallery,” whereupon they "all were shooting through the theatre. The crowd of ladies and children ran out the back way, over the stage, and all was confusion.” The southern sympathizing sheriff discharged his pistol in a sergeant's mouth, killing him instantly, as he called the victim a Union son of a bitch. Other soldiers, as well as gamblers and thugs, were hit. One of the soldiers staggered through the front doors, his uniform pocked with several bullet holes and bleeding profusely, before falling dead on the street. Once word reached the fort, a large number of enlisted men sought out those that killed and wounded their comrades. Inexplicably, all the assailants had escaped some to meet well deserved violent deaths in the region's other mining districts. ${ }^{26}$ Somewhat similar cases of violence between secessionists and the military occurred far to the south, one along the southern California - Nevada border, and the other in the south-central part of California. Demonstrating that the Los Angeles-San Bernardino area was not the only place rife with dangerous secessionists, three members of the First California Cavalry were attacked in La Paz, on the Colorado River, without warning in May 1863. The three were part of a detachment of troops that escorted supplies from Fort Yuma to Fort Mojave. On the return trip, the command stopped in La Paz before continuing back to Fort Yuma. While in town, three of the troopers tragically encountered a man named Edwards, described as "a secessionist desperado who was confined at Yuma."27 Upon seeing the unarmed soldiers, Edwards, who had been

${ }^{26}$ The entire paragraph is based on ibid, 206-07. The incident is not mentioned in the Official Records of the War, which might cast doubt on the story, but this was a much a civilian affair as a military one, so it is plausible that the post commander might not have filed a report. It is more likely is that because this was a civilian criminal incident, when the O.R. was compiled, all communications relevant to this gunfight were not included -a large number of routine communications were not included in the O.R. and are only available in the microfilm copies of the Department of the Pacific correspondence (three volumes). In any event, the editors found sources that corroborate Reinhart's account.

27 O.R., 50:2, 460. 
captured with former state legislator, Daniel Showalter, fired on all three, killing two and seriously wounding the third. Despite stationing troops in La Paz in July, Edwards escaped, undoubtedly due to the assistance of local secessionists. ${ }^{28}$

Two months after those murders, and a bit north and west of La Paz, on August 6, heightening tensions between Visalia, California, secessionists and troops stationed at nearby Camp Babbitt finally boiled over. On that day a pro Confederate local named James Wells murdered Charles Stroble, a sergeant in the Second California Cavalry. As had happened in Walla Walla, the network of local secessionists helped Weller escape before a patrol from the camp arrived. ${ }^{29}$ Lieutenant Colonel William Jones, commanding Camp Babbitt, warned department headquarters, “An outbreak may be looked for at any moment. The rebels are well organized.”30

Although the Walla Walla fire-fight and murders in Visalia and La Paz are extreme cases, they illustrate what General Sumner told Army headquarters: “The secessionists are much the most active and zealous party, which gives them more influence than they ought to have from their numbers.”31 Just before leaving California for glory on the eastern battlefields (and death from a heart attack), Sumner informed his successor, General Wright, “The secession party in this State numbers about 32,000 men, and they are very restless and zealous.”32 As worried as officials were over open support

${ }^{28}$ Ibid, 509.

${ }^{29}$ Hunt, 340-341; O.R., 50:2, 558, 572.

${ }^{30}$ O.R., 50:2, 558.

${ }^{31}$ O.R., 50:2, 472.

32 Ibid, 643. That number, was cause for alarm given that it represented just over ten percent of the state's 1860 population, according to the census. 
for a Pacific Republic, the truly menacing spectre was the significant minority of the population that openly sympathized with the South and the secret organizations of armed southerners said to be sworn to fight on behalf of the South. Both national and local leaders believed such groups were present in every part of the far western frontier. Although these organized and armed societies went by a number of names, including Knights of the Columbian Star, the most often cited organization was the Knights of the Golden Circle. $^{33}$

The society, which envisioned a slave empire that spread out in a circle from Havana, Cuba, and reached as far north at the Mason - Dixon line, was organized as the Knights of the Golden Circle on July 4, 1854, in Lexington, Kentucky, by George Bickley. ${ }^{34}$ Specifically, as Bickley told a Raleigh, North Carolina audience in 1860, The Knights of the Golden Circle constitutes a military organization, as a nucleus around which to hang such political considerations, as will if well managed, lend to the disenthrallment of the cotton States from the oppressive majority of the manufacturing and commercial interests of the North. ${ }^{35}$

By the time the war started there were many clubs throughout the South, including some in Texas and even Mexico, espousing this goal. With a significant minority of southerners living in the far western states and territories and the open support shown for

${ }^{33}$ According to one source, the Knights of the Columbian Star was actually a level or rank within the Knight of the Golden Circle, but given the organization's secretive nature, it was generally assumed to be a separate organization. C.A. Bridges, "The Knights of the Golden Circle: A Filibustering Fantasy,” The Southwestern Historical Journal 44 (1941) 3, 289.

${ }^{34} \mathrm{Ibid}$; In a somewhat dubious history of the KGC, an anonymous author claiming to be a member stated the original idea went back to the 1830s. While this may be true, the preponderance of unlikely claims and the negative tone toward an organization to which the author supposedly belonged makes any factual statements suspect. An Authentic Exposition of the "K.G.C." "Knights of the Golden Circle”: or A History of Secession from 1834 to 1861, (Indianapolis, IN: Perrine Publishers, 1861).

${ }^{35}$ Bickley speech quoted in Leonard B. Waitman, “The Knights of the Golden Circle,” San Bernardino County Museum Association Quarterly, 14 (1968) 4, 2. 
the Confederacy by many of those persons, it is not surprising that clubs were also formed on the Pacific slope following Lincoln’s election.

As Captain Hancock’s experience in the months after war broke out attest, southern California proved to be fertile ground for secessionist sympathizers. This was particularly true in the area between Los Angeles and San Bernardino, where southern sympathies were at least as strong as the attachment to the national government. As one early newspaper editor and politician stated, the southern part of the state was "strongly saturated with the virus of secession at the time.”36 This saturation rattled San Bernardino Judge John Brown, sufficiently that in July he wrote his fellow jurist, Los Angeles Judge Benjamin Hayes: "I fear there will be trouble in this place soon. I have been informed that private secession meetings are held in this city almost every night; there is one to-night, and I was advised this evening to keep my gun in good order.”37

Civilian officials were not the only ones concerned about secessionist plots in southern California. Later on, during the local elections in September 1861, Captain John Davidson, stationed in the Los Angeles area with a company of the First Dragoons, found himself in the middle of an unruly mob of southern sympathizers, "having sticks in their hands, [who] commenced shouting: "Hurrah for Jeff. Davis! Hurrah for the Southern Confederacy. Most of the persons had revolvers. ${ }^{38}$ The blatant disregard for the presence of a uniformed Union officer, whose command was less than half a mile away, did not bode well for maintaining control of the region.

\footnotetext{
36 James J. Ayers, Gold and Sunshine: Reminiscences of Early California, (Boston: The Gorhman Press, 1922), 184.

${ }^{37}$ Benjamin Hayes, Pioneer Notes From the Diaries of Judge Benjamin Hayes, 1849-1875, (New York: Arno Press, 1976), 257.

${ }^{38}$ O.R., 50:1, 614.
} 
Although southern California became the most fertile region to raise new clubs on the Pacific Coast, K.G.C. organizations existed throughout the Far West. ${ }^{39}$ When, in August 1861, a significant number of influential San Franciscans heard rumors that Sumner would lead a large contingent of troops into Mexico and permanently out of California, they protested directly to Secretary of War Simon Cameron. They warned Cameron "The hatred and bitterness toward the Union and Union men . . . is no more intense there [the East] than here.” According to the businessmen, their investigation had "show[n] us that there are upward of 16,000 "Knights of the Golden Circle" in this State, and that they are still organizing even in our most loyal districts." ${ }^{40}$ This number seems radically inflated, but when one considers that Sumner put the number of secessionists within California's borders at 32,000 (which included informant estimates for the Knights of the Golden Circle), the number seems at least possible. ${ }^{41}$

Demonstrating the level of confusion regarding the secessionist movement in general and the membership of the secret organizations specifically, the State of California’s Adjutant General (head of the militia) informed then Commander and Chief of the Union army, Major General Henry Halleck, "It is represented and generally believed that there is a secret organization in this State, numbering between 20,000 and 30,000 men leagued together for the overthrow of our government." ${ }^{42}$ An agent who

${ }^{39}$ Typifying those that do not agree is Peter Wang, “ The Mythical Confederate Plot in Southern California,” San Bernardino County Museum Association Quarterly, 15 (Summer 1969), 4.

${ }^{40}$ O.R., 50:1, 590.

${ }^{41}$ Charles Dustin put the number at 100,000 for the entire West Coast, but did not provide a source for that number. Charles M. Dustin, "The Knights of Golden Circle:” The Story of the Pacific Coast Secessionists,” The Pacific Monthly, November 1911. The 1860 Census lists California’s population at almost exactly 380,000.

42 O.R., 50: 2, 107. 
gained the confidence of some of the organization's members reported in August 1864 the active membership within "the Knights of the Golden Circle and the men they can control, will reach 50,000," but he admitted, "the actual number is very hard to arrive at." ${ }^{43}$ Whatever number is exactly accurate is less important than the fact that department officials and influential civilians believed the threat was genuine at the time.

This confusion was the problem. In order to neutralize any threat that a secret organization such as the K.G.C. might pose, it was imperative that Union officials remain informed about their plans and activities -and, if possible, about the membership. Despite the level of importance, infiltrating an organization in which the membership only knew a few members by sight, proved challenging. Fortunately for each of the Department of the Pacific commanders, Union spies did infiltrate a number of K.G.C. clubs during the war. Although most of the members remained unknown, as did the combined total membership, department spies unearthed significant information about K.G.C. plans, at considerable personal risk.

One such operative, Gustav Brown, confirmed the general suspicions about secessionist sentiments in southern California when he reported his findings about the Knights of the Golden Circle in Los Angeles and San Luis Obispo counties. What Brown's infiltration of the organization uncovered was startling for its depth and dramatically contradictory of previous inflated estimates. While the total number of members in the state was unclear, Brown found out there were 242 members in San Luis Obispo County and 253 in Los Angeles County, and they were all well-armed. Captain Hugh Gorley put the numbers in more colorful terms, saying the K.G.C. were "as thick as

${ }^{43}$ Ibid, 940. 
leaves in Vallambrosa." ${ }^{44}$ From his infiltration, Brown gleaned from the lower level members that "there are men organized in Nevada for the purpose of coming into California in case of an outbreak for the purpose of assisting the Knights." 45

Sifting reports made by other operatives, Captain Robert Robinson of the Provost Marshal's office, explained to his superior why it was so difficult to keep track of K.G. C. activities: "There are no large meetings held of the order in their capacity as an association, but a few only of the officers and the trusted members get together to initiate new members and devise the work which is to be carried out." ${ }^{46}$ Even without the large gatherings, the department responded to the danger posed by the K.G.C.'s strength by sending additional troops to southern California, especially in the first year of the war. The departmental chess game worked well; as a result the K.G.C. were unable to execute any of their clandestine plots.

Despite the overwhelming focus on California (especially the southern part of the state) the entire far western frontier was divided in its sympathies, which proved fertile ground for other K.G.C. clubs. As one Boise basin miner noted, "In this new mining region, as everywhere else, the people were divided in their opinions regarding the war and in their sympathies for those who were actively engaged in it." ${ }^{\text {47 }}$ As the Portland Oregonian reported, the situation was the same throughout that state, where clubs were supposedly formed along the coast and on the Columbia River, which posed a threat to

\footnotetext{
${ }^{44}$ Military Order of the Loyal Legion, California and Oregon Commandry, 60 (Wilimington, N.C.: Broadfoot Publishing, 1991, reprint), 201.

45 O.R., 50:2, 1018.

${ }^{46}$ Ibid, 938.

${ }^{47}$ W.A. Goulder, Reminiscences: Incidents in the Life of a Pioneer in Oregon and Idaho, (Boise,
} ID: Timothy Regan, 1909), 207. 
the commercial traffic on the river. ${ }^{48}$ The Oregonian also reported that the various K.G.C. groups bided their time, waiting for a signal to rise up in all of Oregon's leading towns. ${ }^{49}$ In November, the provost marshal at Fort Hoskins, Oregon reported more disturbing information. A local civilian told him that he overheard "the disunionists making menacing threats against the garrison, such as, 'Well, I have been up there, and I think that we can take the garrison in one hour. . . . We would fire the buildings and shoot the officers as they came out .'” 50 Such bluster would not have jangled the provost so easily had not a portion of the fort's command already been sent elsewhere to protect more important points in California.

In the later part of November, the most terrifying rumors imaginable reached Fort Hoskins. Combining the locals' two greatest fears and presenting the department officials with two of their most challenging responsibilities in one, the provost marshal informed District of Oregon headquarters that at least one southern sympathizer attempted to incite unrest among the tribes. According to the informant, when a man named Newcomb left a gathering of Indians, "he distributed to the Indians guns and revolvers and ammunition, and told them to fight for Jeff. Davis and the Southern Confederacy." 51 The tribesmen, the provost reported, were too wise to fall for the ploy -

${ }^{48}$ Van Winkle, 67. According to the author, the newspaper specifically stated there were K.G.C. clubs in existence in the western towns of Corvallis and Albany and along the Columbia River at The Dalles.
49 Ibid, 77.
50 O.R., 50: 1, 739.
51 Ibid. 
this time. ${ }^{52}$ Although nothing came of the pro-southerner's attempt to agitate unrest among the Puget Sound tribes, news the following year confirmed that there were those still hoping to use the Native Americans to open up a new front, thereby aiding the Confederacy. In October 1862, General Alvord reported hearing rumors about disturbingly similar activity along what is now the border between southeastern Washington and east-central Idaho among the Nez Perce tribes. According to the general, "Seccession sympathizers, fiendish enough to wish to see re-enacted the scenes in Minnesota, may exist there." ${ }^{53}$ Whether or not the plot ever had much chance of success, it never came to fruition, and the Pacific Northwest was spared the horrors of a secessionist supplied Indian war.

Making matters worse for the Department of the Pacific were the southern sympathies of some of the region's political leaders. This made subduing the subversive scheming more difficult until these southern sympathizers were voted out of office. Southern sympathizers, if not full blown pro Confederates, held many important political offices ranging from U.S. senator, House of Representatives members, and governor on down to the local officials, particularly in southern California. That included the mayor of Los Angeles, Damien Marchessault, who was reportedly a secessionist. ${ }^{54}$ At the start of the war both California and Oregon were represented in the Senate by vocal opponents of the Republican candidate and the party's platform, and many considered California's

52 The threat of an uprising led the Siletz Indian Agent to call for additional troops in midDecember 1861. Troops were dispatched to the area, but not in response to the secessionist attempts to incite the Indians. O.R., 50:1, 768.

${ }^{53}$ O.R., 50:2, 177. Alvord's reference to Minnesota refers to the bloody Santee Sioux uprising that devastated the state in 1862.

${ }^{54}$ O.R., 50:1, 552. 
William Gwin and Oregon’s Joseph Lane to be secessionist (Lane had been the vice presidential candidate on the Breckinridge ticket). ${ }^{55}$ In 1860 the Knights of the Golden Circle openly supported John Downey for governor of California. Downey did become governor after Milton Latham resigned the post to assume the state’s vacant senate seat. ${ }^{56}$ In the southern part of the state, during the fall 1861 elections, the locals chose almost exclusively anti government candidates.

The situation was the same to the north, in the Pacific Northwest segment of the department. In Walla Walla, the county sheriff and the city marshal were both avowed secessionists, as were other local officials in many of the mining boom towns. ${ }^{57}$ Worse yet, one of the most belligerent opponents of the federal government (many said pro Confederate) on the West Coast was Oregon's governor, John Whiteaker. The governor proved so uncooperative when called upon to raise a regiment of volunteers to help protect the Far West that the responsibility was eventually turned over to prominent citizens. Showing just how little trust the War Department had in Governor Whiteaker's allegiance to the Union, on September 24,

The War Department being convinced of the necessity of raising a body of troops in Oregon to meet all exigencies which may exist there, and with a particular view to the defense of the frontier, I am directed to authorize you [Thomas Cornelius, Benjamin Harding, and Reuben Maury] to raise for the service of the United States one regiment of mounted troops. ${ }^{58}$

55 In a letter to a southern friend Lane wrote, "I am glad a majority of people in Oregon have determined to leave a Union that refuses you equality of protection.” Cited in Walter C. Woodward, The Rise and Early History of Political Parties in Oregon, 1843-1868, (Portland, OR: The J.K. Gill Company, 1913), 193.

56 Henry H. Goldman, “Southern Sympathy in Southern California, 1860-1865, ” Journal of the West, 4 (1965) 4: 581. To be fair, Governor Downey worked well, more or less, with Generals Sumner and Wright.

57 Nunis (editor), 205.

58 Ibid, 632. 
The three men who served as the First Oregon's regimental officers were told to report to former Oregon senator Edward Baker, then a colonel in Virginia and to take their orders from him. Whiteaker's persistent opposition to federal authority necessitated this unwieldy arrangement, until Baker’s death in late 1861.

Having been circumvented by the War Department, the governor followed a course of belligerent resistance in all future dealings with both civilian and military departmental officials. ${ }^{59}$ In one editorial, an Oregon newspaper editor, disgusted by Whiteaker’s pro-southern attitude and obstructionist tactics, lamented, “poor fiddling Whiteaker, 'Old Cat Gut' is the biggest ass in the State."60 Echoing this sentiment, Judge R. E. Stratton warned Department of the Pacific headquarters in the summer of 1861, "It is not to be doubted that the Governor of this State strongly sympathizes with the rebels.” “Oregon,” he added, "has a large faction of her population who are as devoted to the rebels as any men to be found in the South." 61

With southern sympathizers holding a number of western political offices, and a significant -and vocal- secessionist population throughout the Pacific slope, the Department of the Pacific faced a daunting challenge. ${ }^{62}$ Although the military presence in the region was greater than before the war, department leaders never had enough

59 With unmistakable anger, the governor refused to keep the War Department informed about the attempt to raise a regiment, explaining that he knew only what the newspapers reported about the purported effort and since he did not know those recruiting the regiment, he had nothing to report. O.R., 50:1, 918, 1090.

60 Roger Van Winkle, "A Crisis in Obscurity: A Study of Pro-Southern Activities in Oregon, 1854-1865,” (Master's Thesis, Western Washington University, 1968), 60 -quoting the Oregon City, Argus on June 8, 1861.

61 O.R., 50:1, 571 .

62 This included the well-organized and armed Knights of the Golden Circle. 
troops to address their multiple responsibilities; therefore, they did not have massed troops to suppress uprisings and keep the region within the Union. Just as they did when dealing with the Native American threat, department officials moved troops from one reported secessionist hotbed to another. By doing so, they prevented secessionists from gaining control of any part of the Far West or menacing the important gold fields and shipments. One of the best methods to defeat any such dangers was to remain abreast of all secessionist activity. With the knowledge of what the southern sympathizers planned to do, department leaders attempted to overawe the recalcitrant secessionists while limiting the danger of exposing other areas within the department's borders.

The first step to securing the Far West for the Union was to silence, or at least quiet, the secessionist enclaves. The trouble with that strategy, however, was that there was no place with a heavily concentrated pro-Confederate population. The majority of southern sympathizers were scattered throughout the small frontier mining and farm communities. The one significant exception was southern California, where civilian and military leaders alike believed southern sympathizers abounded. All three of the department’s last commanders felt the Los Angles - San Bernardino area was rife with secessionists. Therefore, when considering how the department dealt with the internal threat through its vast expanse, it is important to examine how it maintained Union control over the most volatile southern hot spot on the Pacific slope.

Even before the war broke out, lightly-populated southern California had a reputation for harboring southern sympathies and antagonism toward the federal government. One military official believed this was, at least in part, due to the large Mormon population in the region, particularly in the San Bernardino area. As he put it, 
"The Mormons, whatever their professions, hate us [the federal government/military] at heart." ${ }^{\prime 3}$ Furthermore, the "open sedition and treason among the whole people” appalled the officer. ${ }^{64}$ Los Angeles Judge Benjamin Hayes spoke for many officials in those days when he asked the simple question: "What are the Mormons doing?"65

The Mormon population, which seemed strongest near San Bernardino and in the adjacent Holcomb Valley, could not by itself, however, account for the region's anti government atmosphere. That there was a significant population of southern sympathizing in the lower part of the state led the Confederate high command to dream of a Pacific outlet. According to Confederate Captain Trevanion Teel, the southern government assumed there was a large enough number of secessionists in the Southwest (what is now southern portions of New Mexico, Arizona, and California) that the arrival of an invading Confederate force would be welcomed. From these secessionists, the government anticipated organizing a large army with which to conquer California. ${ }^{66}$ In early January 1862 the usually unruffled Judge Hayes acknowledged that even he feared the region's Confederate supporters might initiate internal fighting. On the ninth of that month he wrote in his diary: "I begin now, indeed, to apprehend that we are on the eve of witnessing serious evils in this beautiful section of the State. A war here would certainly

${ }^{63}$ O.R., 50:1, 548.

${ }^{64}$ Ibid, 551.

${ }^{65}$ Hayes, 259.

${ }^{66}$ T.T. Teel, "Sibley’s New Mexico Campaign - Its Objects and the Causes of its Failure," in Robert Johnson and Clarence Buel, Battles and Leaders of the Civil War, (New York: The Century Company, 1887-1888) 2: 700. 
be utterly ruinous to all our material interests; and would be likely to stain our annals with tales of bloodshed." ${ }^{67}$

Well before the judge pondered the frightening possibilities, General Sumner took steps to alleviate his own apprehension about keeping the southern part of California in the Union. Once he became acclimated to the dangers and challenges of his new command, Sumner acted quickly to preempt any secessionist uprisings. He understood the areas posing the greatest danger to Union control were the southern part of California, as well as in the Carson City, Nevada Territory vicinity. Wasting as little time as possible, Sumner began taking steps to secure both regions in late April, when he reshuffled his scattered force. ${ }^{68}$

Just as he removed troops from the District of Oregon and northeastern California's Fort Crook and ordered them to the San Francisco area to shore up the defenses of that key location, Sumner also consolidated his forces in southern California, concentrating them where he believed the secessionist threat was greatest. On April 29, Sumner ordered Fort Mojave abandoned, with instructions for its garrison to establish a base near Los Angeles. ${ }^{69}$ As Sumner explained to Army headquarters in Washington, "I have found it necessary to withdraw the troops from Fort Mojave and place them at Los Angeles. There is more danger of disaffection at this place than any other in the State.”70 Clearly, expediency in bringing a larger force to the Los Angeles area was paramount. Therefore, not only did Sumner order the troops from Fort Mojave to the town, three days

\footnotetext{
${ }^{67}$ Hayes, 262.

${ }^{68}$ O.R., 50:1, 474. Fort Mojave was ordered abandoned on April 29 and Fort Tejon on June 7.

69 The fort was in what is now western Arizona near the Colorado River.

${ }^{70}$ O.R., 50:1, 474.
} 
later a company from Fort Tejon was also ordered closer to Los Angeles. ${ }^{71}$ At the same time, the forts’ commander, Brevet Major James Carleton, was placed in command of all the troops in the general area, thereby streamlining the chain of command. ${ }^{72}$ To further bolster this larger command, two howitzers were added to Carleton's force, while one company was sent further south to San Diego. ${ }^{73}$ These were the first steps to overawe southern California's secessionists and to snuff out any hope they might have of rising up and taking control of the region.

On June 7 Carleton received orders to abandon Fort Tejon as well and to move the remaining troops to the newly created Camp Fitzgerald, a temporary base first occupied on May 14, 1861. ${ }^{74}$ By the end of June there were four infantry companies and the two howitzers in Los Angeles. Concerns about the possibility of an election day uprising in another southern part of the state resulted in Carleton's receiving orders in mid-July to personally gauge the attitude of San Bernardino residents and to assess the level of threat. ${ }^{75}$ The situation there proved unsettling and Carleton advised that there needed to be a camp in the vicinity. Eventually, the department heeded his advice and established Camp Carleton. $^{76}$

${ }^{71}$ Fort Mojave is located on California's eastern border, near the convergence of Arizona and Nevada. Robert W. Frazer, Forts of the West, (Norman, OK: University of Oklahoma Press, 1972), 10.

72 Ibid, 475.

73 Ibid, 485.

74 Ibid, 538; Lloyd Wayne Herbener, “The Military Establishment in Southern California during the Civil War,” (Master’s thesis, Claremont Graduate School, 1952), 296-297.

75 O.R., 50:1, 549.

76 Ibid; the camp was situated northeast of El Monte, on the San Gabriel River, Herbener, 296. 
The strategy paid off. Even though the region voted a number of anti government candidates into office, only minor subversive activity broke out. However, the atmosphere had been volatile; as the commander of the troops in San Bernardino noted, there had been "one or two displays of secession sentiments, which were promptly checked by the show of a portion of the dragoons." Never-the-less, the locals "expressed the belief that the measures taken by the general and the arrangements made by myself prevented great trouble, if not much bloodshed." 77 Still, "the secessionists are much more numerous than the Union men in this section of the country .... I am satisfied that the sudden and unexpected appearance of the dragoons had a very beneficial [controlling] effect." 78

The presence of a number of infantry companies and the dragoons did temporarily end the secessionists' public scheming in southern California, but Department of the Pacific officials faced usurper threats in other parts of its jurisdiction as well. As Confederate victories mounted throughout the summer, secessionists in the Far West grew bolder and more vocal in both their support for the South and their threats to assist it. In addition to the strong secessionist presence in southern California, department officials heard increasing rumblings about a concentration of Confederate sympathizers in and around Carson City, Nevada Territory.

With only the under-strengthed contingent at Fort Churchill, Nevadans took matters into their own hands, keeping vigilant watch over the secessionists. Without sufficient arms with which to equip themselves, more or less all they could do was report

\footnotetext{
77 O.R., 50:1, 606.

${ }^{78}$ Ibid.
} 
treasonous activity to the commander at the fort or directly to department headquarters.

One such group wrote to the commanding officer at the fort: "We are confidently assured that the secessionists have completed an organization of over $100 \ldots$ The general impression is to seize the fort and get possession of the Territory."79 Two weeks later informants, rightly or wrongly, estimated the number of active pro Confederates had increased to over 200. The commanding officer at Fort Churchill informed department headquarters "This gang of men is well armed and is composed of such men as have for some months bid defiance to the laws of the Territory."80 Making matters worse, there was a quantity of arms and ammunition, belonging to the state of California, warehoused in Carson City, a tempting cache for those wanting to challenge federal authority in the region. ${ }^{81}$

General Sumner responded to the danger in Nevada Territory just as he had in southern California. In early June he provided the U.S. Army Adjutant General's office with an overview of his efforts to quell internal unrest in southern California and Nevada.

I have found it necessary to withdraw from Oregon a considerable part of the force stationed there to re-enforce the troops in California and Nevada Territory . . . . I have checked them [Confederate sympathizers] in the southern part of this State by placing a strong command at Los Angeles, and they are now trying to organize in Nevada Territory, but I am moving re-enforcements rapidly to Fort Churchill, which will put down this movement. ${ }^{82}$

A key part of Sumner's strategy, beyond reinforcing Fort Churchill, was to gather up all the public arms and to distribute as many of them as were needed to loyal militia units,
${ }^{79}$ O.R., 50:1, 490.
${ }^{80}$ Ibid, 499.
${ }^{81}$ Ibid, 502, 509-511.
${ }^{82}$ Ibid, 506. 
while simultaneously searching for any stolen weapons that might be traced back to the secessionists, and to arrest anyone with ties to any such weapons. Responsibility for this task fell to assistant quartermaster Captain Treadwell Moore, who searched a number of buildings, including private homes, and arrested a few Silver City and Virginia City residents suspected of hiding stolen weapons. ${ }^{83}$ Although Moore later released everyone he arrested and only confiscated those weapons he could find, his presence sent the secessionists underground and encouraged local Unionists to form two companies of militia. ${ }^{84}$ Moore's active presence combined with the distribution of additional guns to the loyal militia and the expansion of the garrison at Fort Churchill to four companies quelled any further secessionist activities in Carson valley - for the time being.

Sumner's reshuffling of troops to address the department's changed responsibilities, which included defending the vast territory encompassed within its borders against internal threats, proved successful, and although a number of anti government (and some open secessionists) were elected to office that fall, quiet prevailed. The jockeying of troops throughout the department deflated secessionist schemes in all regions, and not just the two locations where a concentration of southern sympathizers existed. With the Confederate invasion of New Mexico Territory late in 1861, the department achieved an important victory by subduing the secessionist movement within southern California and west-central Nevada Territory. Although there was more unrest in the department during the following years, particularly in southern California, quelling internal unrest at that time was especially important considering that, as Captain Teel

\footnotetext{
83 O.R., 50:1, 510.

84 Moore turned over the confiscated weapons to the militia commands.
} 
stated, the Confederates hoped to create an army from the southern sympathizing elements in the southwestern lands.

Keeping the undercurrent of secessionist sentiment from erupting in any region within the department was one of the its primary responsibilities, and having done so in 1861 was a victory for the Union's most remote department. However, there were other ways the secessionist element challenged the Department of the Pacific's control over the far ranging lands. Within the general populace of dissatisfied spirits there existed those that did not plan to wait for a Confederate invasion, or a general uprising, to launch their support for the southern cause. The department faced the additional task of preventing those southern sympathizers from leaving the region to join Confederacy. The danger of that happening decreased rapidly after 1861, but from the outset of the war until the early months of 1862 the troops in the southern part of the Department of the Pacific remained busy trying to stop the boldest of the secessionists from joining the Confederate ranks. Two groups of influential southern sympathizers were among those that undertook the dangerous endeavor during the war's first year.

With such a massive area to protect, it might appear the border would have been too porous for department officials to have hoped to prohibit the flight of anyone wishing to fight for the Confederacy. For practical reasons, however, this was not the case. Given the Pacific slope's daunting distance from the main fields of conflict, there were few possible routes that presented any real hope of reaching the contested lands. Further complicating the situation for would-be Confederate soldiers was the fact that most routes led to Union states. The best path to take, and here best is used rather generously, was the southern route, which headed east from southern California, through New Mexico 
Territory, and finally into Texas. As harsh as the trek across the sun-baked Arizona-New Mexico-Texas deserts was, it was the shortest route to Confederate territory. Doing so was noticeably more plausible late in 1861 and early 1862 when actual Confederate troops occupied part of New Mexico.

No one could question the commitment to the southern cause of anyone who undertook the long journey across the burning hot deserts of Arizona and New Mexico just to reach the active battlefields. That a few brave (or desperate) souls undertook the trek attests both to the inability to cross on any other land route and to the Department of the Pacific and Pacific Squadron's ability to prohibit anyone trying to flee aboard ocean going ships. Under these limiting circumstances, there was only one good debarkation point, and a federal fort sat on a rise overlooking it.

In California's southeastern corner, where the turgid Colorado River is met by the Gila River, thus separating present-day Arizona from the Sunshine State, Fort Yuma rested on a hill like a sentinel above the river. This arid, stiflingly hot, entirely inhospitable place was the point at which the southern transcontinental route (and Butterfield stage line) crossed into California. For those individuals determined to head east to join the Confederate forces, this was also the starting point for an eastward odyssey that required traversing the debilitatingly hot and dry cactus lands of New Mexico Territory and west Texas.

On June 16, 1861, a small party of men set out from Los Angeles for Fort Yuma with plans to press across the deserts before them until they reached Texas in their efforts to join the Confederate fighting forces. The leader of this small party, joined by a considerable number of like-minded individuals before they reached Fort Yuma, was 
former department commander Albert Sidney Johnston and seven other former federal officers. ${ }^{85}$ Knowing efforts to arrest him would soon be underway, Johnston left Los Angeles a week ahead of his (well orchestrated) rumored departure, and thereby reached Yuma before the net could be drawn around him. His party arrived at the fort on July 4, and left shortly thereafter to stay ahead of either an arresting party or orders for the forces at Fort Yuma to arrest him. One of the party recalled they left "after the sun had sunk low enough to permit the waters of the spring to cool so that our animals would drink." The many years in the West as a cavalry officer had both tempered Johnston like steel and enabled him to anticipate how his former colleagues would go about trying to capture him, thus he pressed on and thereby escaped before department orders for his arrest reached Fort Yuma. ${ }^{87}$ The department had failed to prevent the departure of the most important group of Confederate supporters to make the bold attempt during the entire war. Others, however, were not so fortunate.

The Johnston party’s escape had a very perceptible impact on the Confederacy, as Johnston became the second highest ranking general in the Confederate armies, before being killed at Shiloh the following April. There was a future brigadier general and colonel among the rest of the group, three of whom gave their lives in battle (making four

\footnotetext{
${ }^{85}$ William P. Johnston, The Life of Gen. Albert Sidney Johnston, (New York: D. Appleton and Company, 1878), 279.

${ }^{86}$ Johnston, 281, citing Gift letter.

87 Brian McGinty, “I Will Call a Traitor a Traitor,” Civil War Times Illustrated, 20 (1981) 3, 2930; Roland, 252-253.
} 
altogether counting Johnston). ${ }^{88}$ Thus, Johnston's escape had been an important failure by the department.

Success, however, did not always greet similar efforts. In late November former state senator, Daniel Showalter, and roughly 20 followers attempted to replicate Johnston's successful escape from California. Although the Showalter party was not as important as Johnston and his companions, they were still well known by department officials, and they were determined to prevent them from joining the Confederate forces in New Mexico Territory. By this time this responsibility fell to the first volunteers to take the field, who replaced the Regular Army commands when the latter left to shore up the forces in the East. To prohibit any secessionists from slipping past the troops at Fort Yuma, Colonel James Carelton, now the District of Southern California commander, ordered the troops to confiscate all ferry boats on either side of the Colorado for 30 miles in both directions. ${ }^{89}$ In addition to blocking the eastern escape route, Carleton ordered patrols sent from Camp Wright, near Los Angeles. If they came across any large and suspicious parties traveling eastward toward the border, they were to "stop it, search the persons and baggage if you suspect them of being enemies of our country.” If the search produced "evidence of their being disloyal, or of their giving aid and comfort to the enemy, hold them in confinement and report all the facts and all the evidence in each case to me." 90

${ }^{88}$ Lewis Armistead had been a major in the U.S. Army before he resigned; he led the brigade that penetrated the Union lines during Pickett's charge, where he was killed, and Lieutenant Edward Riley eventually rose to the rank of colonel in the Confederate Army.

${ }^{89}$ O.R., 50:1, 698.

${ }^{90}$ Ibid, 699. 
Unfortunately for the Showalter party, Carelton knew of their intentions and was better prepared to stop them than had been the troops the previous July. Worse yet, Showalter failed to outwit the Union troops as Johnston had, and furthermore, he did not possess Johnston's calm, but hardened determination. Given Showalter's shortcomings and the Union troops' diligence, the likelihood of the party's escaping California was slim. To enhance their chances, they planned to cross the Colorado "river about thirty miles below Fort Yuma on the Sonora side," and travel under the guise that they were prospectors heading to Sonora. ${ }^{91}$ With Fort Yuma ahead of them and patrols circling toward them from behind, the group was more or less trapped, although they did not know it until it was too late.

On November 29 a troop of First California cavalrymen surprised the main body of the Showalter party (two scouts sent ahead of the group had already been captured). Major Edwin Rigg, who sent the pursuing troops after the secessionists, informed his superior: "The party consists of sixteen men, each man armed with a rifle and pair of revolvers. They gave us a hard chase, but we finally captured them."92 Carleton ordered Rigg to send the prisoners to Fort Yuma, which served as something akin to a political prison for much of the war. Astonishingly, the entire party was released less than six months later. Despite the quick release, the notorious group's capture and incarceration dissuaded others -but not all- from attempting to reach the Confederates then in New Mexico. ${ }^{93}$ By the end of the year department officials could be proud of their success in

${ }^{91}$ Ibid, 41.

${ }^{92}$ O.R. 50:1, 33.

93 Among those that succeeded in escaping California and joining the Confederate forces was Judge David Terry, who killed a political opponent in a duel in 1859. Ibid, 490, 499-500, 621. 
greatly reducing, if not completely stopping, the secessionist flight from southern California. Although fewer and fewer persons attempted to make their way from southeastern California to New Mexico Territory/Texas as the war progressed, the Union troops stationed in the region maintained their vigilance throughout the rest of the war.

While the number of secessionists attempting to escape the Far West for the Confederacy diminished as the war progressed, the internal threat did not. In fact, the two boldest actions taken by Confederate sympathizers within the department borders occurred after the war was well under way. Although possession of the entire Pacific slope would have been a tremendous boon to the desperate South, California was the main prize. California’s Pacific ports could greatly aid the southern cause by giving the southerners a port beyond the Union blockade, but mostly the Confederacy desperately needed its gold. Control of California would not simply provide the South with a reliable source of wealth, it would simultaneously deny the Union millions of dollars in gold each year.

Unfortunately for the Confederacy, once Union troops turned back the invasion from the Southwest in the spring of 1862, the possibility of conquering California evaporated. The Confederate defeat and subsequent stumbling retreat to Texas ended the dream of a coast-to-coast Confederacy - for both the southern leaders in Richmond and for West Coast secessionists. As severe as that blow was to the region's pro-Confederate population, it did not extinguish their determination to aid the South by attacking the gold supply. In fact, if anything, it forced the secessionists to craft more imaginative, more fantastic, schemes. 
The problem facing the Confederate sympathizers was not acquiring gold; that was the easy part. Their challenge centered on taking as much gold as possible at any one time, and limiting the number of raids. Clearly, this precluded robbing the hardscrabble individual miners, few of whom had more than a half-full pocket of gold at any one time. If western secessionists hoped to aid the Confederacy, they needed to strike on a much larger scale. Not only would that enhance the value taken in any one attack, it would also lessen the likelihood of capture. Under these circumstances the options were limited; attacks could be made either on the various gold expresses that carried bullion from local banks to San Francisco; the secessionists could rob any of the holding banks, or, most grandiose -and most rewarding- of all, they could find a way to attack the ocean going gold shipments on their way east. In the end, two actual attempts were carried out separately, and there is no indication of any centralized organization that planned similar efforts elsewhere.

Prior to the completion of the transcontinental railroad in May 1869, the only feasible method of transporting large quantities of goods to or from the Pacific Coast was to send them via ocean-going ships. That long, tedious, and generally expensive method meant little was shipped back from the Pacific states. The one exception was California gold. Not since the Spanish galleons carried North American treasure back to Europe had ships leaving American ports transported such wealth as the years after the Gold Rush. The American government had always been concerned about the security of those shipments, and those worries magnified exponentially after the Civil War broke out. Given the activities of such Confederate raiders at the C.S.S. Alabama and the previously 
noted attempts to outfit a British ship at Vancouver Island to prey on American shipping in the north Pacific, those concerns were warranted.

Despite the attractiveness of pirate operations against the gold shipments (and other commerce), it was not until 1863 that southern sympathizers living on the West Coast undertook the bold enterprise. As had been true when trying to launch raids from Vancouver Island, the primary challenge facing anyone trying to outfit a raider along the Pacific states was acquiring an adequate vessel. This was no simple task considering the authorities (both local and federal) understood such an effort might be attempted, therefore, they employed undercover agents to remain abreast of any activity involving a large enough ship that could attack commercial vessels on the ocean. However, if a ship could be acquired, the risks lessened once at sea, and the rewards could be significant. The Pacific squadron was stretched terribly thin, therefore capture on the seas seemed unlikely, and most tantalizing of all, each of the Pacific Mail Steamship’s gold shipments carried roughly one million dollars worth of bullion in its hull. $^{94}$

In the early hours of March 15, 1863 a group of less than 20 secessionists finally actualized their plan to attack the gold ships that ran from San Francisco to Panama. The plan, concocted by southerner Asbury Harpending, was

to sail the Chapman to some islands off the coast of Mexico, transform her into a fighting craft, proceed to Manzanillo [Mexico], exhibit our letters of marque and my captain's commission in the Confederate Navy and then lie in wait for the first Pacific Mail liner that entered the harbor, capture her - peacefully if possible, forcibly if we must.

94 Francis X. Holbrook, “To Strike a Blow at the California Trade,” The American Neptune Society, 32 (1972) 2, 197. 
Once the first ship was captured, Harpending continued, the pirates planned to transform the Pacific Mail ship into a (bigger) privateer with which to prey on the other gold ships before word of their activity spread. ${ }^{95}$ The first step in this bold plan was acquiring a ship. The conspirators' initial obstacle was that they did not have enough money to purchase a satisfactory ship; therefore, the scheme was put on hold until February. Finally, an infusion of money from one of the would-be privateers enabled them to purchase the J.M. Chapman. Preparations, which had to be done as inconspicuously as possible so as to avoid detection, went slowly. For the next few weeks the privateers loaded war material aboard the ship and made modifications to make it ready for a career as a sea raider. ${ }^{96}$

Unfortunately for Harpending and his c-conspirators, their efforts did not go unnoticed. As Department of the Pacific commander General Wright informed the Army Adjutant General, "The collector of this port and officials of the Government, as well as the city authorities, were on the alert to detect any parties who might engage in such a business. A schooner [J.M Chapman] attracted attention., ${ }^{, 97}$ On the morning of March 15, unaware they had been detected and were under constant surveillance, the Chapman left its moorings and started to ease out of the harbor. A boarding party from the one man of war available, the U.S.S. Cyane, quickly pulled alongside the Chapman and climbed aboard. Being overmatched, neither the crew nor the additional men hiding below deck resisted, and the ship was captured without incident. When members of the

\footnotetext{
${ }^{95}$ Harpending quoted in Donald E. Bastin, "Rebels at the Gate: Civil War San Francisco and the Confederate Sea-borne Threat,” (Master’s thesis, California State University, Hayward, 2001), 57.

96 Aurora Hunt, The Army of the Pacific, 1860-1866, (Glendale, CA: Arthur Clark, 1951), 30607.

${ }^{97}$ O.R., 50:2, 363.
} 
boarding party discovered Harpending, he was "chewing and tearing up papers, which he [sailor from the Cyane] doubts not were the letter of marque and instructions." ${ }^{98}$

Once the authorities knew of the plan, the scheme was doomed. Had the ship somehow gotten past the Cyane, it would have been obliterated at the entrance to the reinforced harbor, where Sumner and Wright had combined to order the placement of well over 100 pieces of heavy artillery. Even before the purchase of the Chapman, department personnel, along with naval and civilian authorities, knew some attempt was being made to acquire and outfit a ship as a raider. For some time, as Wright noted, "suspicions have been entertained that attempts were being made to fit out rebel cruisers, either on Puget Sound or in the harbor of San Francisco, for the purpose of preying upon our commerce on the Pacific.”99 This awareness enabled the military (both naval and land) authorities to work with their civilian counterparts to thwart this bold attempt as well as remain abreast of all other designs to attack the gold shipments, none of which were ever tried.

The failure of the Chapman scheme, along with the inability to purchase a ship in Victoria, ended any hope of outfitting a Confederate raider on the West Coast. However, other Confederate agents found alternate ways to aid the Confederacy. While the bullion ships, laden with western gold destined for the East Coast, were natural targets, obviously devising a successful plan to capture any of them was difficult. Banks in San Francisco, where gold was held before being loaded onto those ocean going ships, housed the next largest quantities of gold. Any thoughts of robbing those banks of large (and heavy)
${ }^{98}$ Ibid.
99 Ibid. 
quantities of gold were even more impractical than trying to seize gold shipments on the ocean. Any such attempt would, itself, be a challenge because the banks understood the danger, and therefore exercised extra vigilance. Furthermore, the likelihood of fleeing with wagons full of gold through the city without being stopped presented additional dangers, given the fact that they would first have to elude any bank guards, then civilian authorities, and finally, the military. As no such plot ever surfaced, the combined difficulties apparently precluded the secessionists from concocting any such schemes.

With the failure of the seaborne attempt to capture western gold and the impossibility of a raid on one of the banks warehousing the bullion succeeding, there remained just one way to acquire a significant quantity of the much needed wealth, albeit less than could be captured from a gold shipment or robbing a bank. The gold that accumulated in San Francisco banks, waiting to be sent on the circuitous ocean trip to the East, arrived in the city via stagecoach. All traveled considerable distances, and most of those routes went through uninhabited, rugged country. A Wells Fargo strong box full of gold bullion and coins, guarded by at most three men (and any daring passengers inside the coach) made for an inviting target. Finally, on June 30, 1864 a small band that claimed to be authorized Confederate agents came to the same conclusion and set in motion the robbery of stage expresses transporting gold down from the Sierra Nevada Mountains. The stated purpose was to use the gold to raise and arm Confederate units in California, where many still believed there was an undercurrent of secessionism. ${ }^{100}$

${ }^{100}$ Karen Sue Hockemeyer, "The Southern Minority? The Strength of the Confederate and the Copperhead Sentiment in Santa Clara County, California, 1860-1865,” (Master's thesis, San Jose State University, 1987), 132-133; Clarence C. Clendenen, "A Confederate Spy in California: A Curious Incident of the Civil War,” Southern California Quarterly, 45 (1963) 3, 229-230. 
That evening, six men, one wearing a Confederate captain's uniform, held up the Pioneer Company Stage’s Virginia City (Nevada) - Sacramento stage, near Placerville. They ordered the driver to throw down the Wells Fargo strong box, filled with seven sacks of bullion and \$2,000 worth of gold coins. They did not, however, rob any of the passengers. Before ordering the stage to proceed, the leader, R. Henry Ingram (who wore the Confederate uniform) handed the express driver a receipt that stated the gold had been taken on behalf of the Confederate military, with the purpose of outfitting recruits in California. The band attempted to rob the next stage, but failed before fading into the darkness. $^{101}$

Whether or not the party was comprised of Confederates, secessionists, or merely imaginative highwaymen, the robbery was a civil matter. Therefore, the following morning a posse of local law enforcement officials set out in pursuit. The posse caught up with some of the robbers that day and attempted to arrest them, at which time a gun battled erupted. Two gang members were caught, at least one of whom was later executed, and a deputy sheriff was killed. Two weeks later, most of the remaining members of the group were cornered in a farm house, but rather than surrender, the heavily armed men fought it out with the posse. That decision resulted in the mortal wounding of two "secessionist” highway men and the capture of all but one of the rest. The local officials did not give up their pursuit of anyone else who might have been involved in the plotting or supporting of the robbery. In fact, the focus shifted to those that provided protection to the group. Those effort resulted in the arrest of a number of noted Democrats and individuals known to harbor southern sympathies. Fearful that

101 Hockemeyer, 133; Clendenen, 230. 
some of their allies would attempt to capture the jail and free their friends, the local officials received reinforcements from a detachment from the Fifth California Infantry. ${ }^{102}$ Whether or not the gang that robbed the stage and those that supported them were authorized to raise troops for the Confederacy is uncertain, but the testimony of the one gang member eventually executed (for the murder of the deputy sheriff) sparked deep concern. According to the defendant, Thomas Poole, he belonged to "a band of men whose purpose it was to form a company for the Confederate army," committed "to resist to the last if the military authorities or any one else attempted to interfere with them.”103 The sequence of events and, in particular, this testimony rattled the local population. It also shows the importance of civilian cooperation in the effort to protect the Far West from internal threats, particularly when danger was just as likely to be non military as military in nature.

With the war winding down in the fall of 1864 and the secessionists' failure to find a successful means to attack the gold shipments, it became less and less likely there would be any serious threat to West Coast security. There was little -maybe no - chance that any secessionist action, of any kind, could materially aid the Confederacy by this stage in the war. This being the case, the pro Confederate element in the Far West grew increasingly quiet during the last months of the war.

When the war finally sputtered to a bloody conclusion in April and May 1865, Department of Pacific leaders and troops could be proud of their ability to keep secessionists from either taking the Pacific slope out of the Union (with its much-needed

102 Hockemeyer, 134-135, 137-141. R. Henry Ingram was never captured.

103 Poole testimony quoted in Ibid, 146. 
gold, and then later joining the Confederacy) or initiating a destructive, and distracting, regional civil war. Furthermore, the department's ability to squelch subversive activity, most often before it was much underway, prevented western secessionists from drawing troops away from the eastern theatres of the war, and thereby weakening the main Union armies. The truth was that the Department of the Pacific performed its three primary tasks remarkably well. Those responsibilities included, first and foremost, maintaining Union control of the region, protecting the gold shipments, and prohibiting southern sympathizers in the Far West from joining the Confederacy.

Preventing an insurrection, with its myriad of possible outcomes, from breaking out was the Department of the Pacific's most important responsibility, and therefore its greatest success and contribution to the Union war effort. By shuffling troops from one secessionist hot bed to another, establishing posts in the most volatile regions, and using force to deter those crafting clandestine schemes to overthrow federal control authority (this was particularly so with the infiltration of secret organizations such as the Knights of the Golden Circle), Department of the Pacific leaders and troops prevented a costly uprising in the Far West. The failure of internal plans to separate the region from the Union, combined with the inability of a Confederate invasion force to reach California and conquer the area, meant a tremendous lost opportunity (both economically and politically) for the South. A significant part of that lost opportunity, of course, was the failure to capture gold shipments - either on the sea or in large quantities in California or Nevada Territory. The department's ability to protect the gold shipments meant the national government could count on the annual infusion of over one million dollars in gold bullion at a time when the reliance on greenbacks grew exponentially. Such gold 
resources gave greenbacks greater, although certainly not overwhelming, credence, and the South’s failure to acquire hard currency greatly hampered its ability to purchase much-needed war material overseas. Thus, by safely protecting the gold shipments from land and sea (originating along the Pacific Coast) attacks, the Department of the Pacific greatly aided the Union war effort while simultaneously hurting the Confederacy. ${ }^{104}$ Although less important than holding the Pacific slope for the Union and protecting the gold shipments, the department did a solid job of diminishing the number of far western secessionists who escaped to the Confederate states. By doing so they reduced this relatively small manpower source drastically. ${ }^{105}$ Furthermore, by manning forts in key locations to slow the secessionist exodus, leaders strengthened the department's southeastern border against possible invasion. In short, the Department of the Pacific did an outstanding job of suppressing the insurgent sentiment that lingered throughout the Far West during the war, and it did so at a time when it faced a growing cacophony of dangers.

104 Of course, once the shipments were transported across Panama, the Department of the Pacific and Pacific Squadron were no longer responsible for the gold's safety. By prohibiting Confederate agents from acquiring and outfitting a ship as a raider, land and sea forces, with the assistance of the local civilian authorities, eliminated any chance that an attack would be made by from far western waters.

105 Although General Johnston and his party managed to escape to Texas, and then join the Confederacy, it must be recalled that the order to arrest the general came after he was already underway. While department officials did capture former state congressman, Dan Showalter, and his party, they failed to capture the notorious southern sympathizing Judge David S. Terry, former chief justice of the state supreme court. Overall, the cavalry patrols through the south-central and southern parts of the state, combined with the presence of Fort Yuma on the Colorado and Gila river junction reduce the number of persons willing to attempt an escape -and the harsh desert climate discouraged many others. 


\section{CHAPTER}

$-4-$

\section{SOUTHERN SCHEMES AND BRITISH BLUSTER IN THE PACIFIC NORTHWEST DURING THE CIVIL WAR: THE DEPARTMENT OF THE PACIFIC AND THE NORTHERN BORDER}

During the Civil War, the situation north of the border presented Department of the Pacific leaders and regional political officials with potential dangers singularly different than those churning below the southern border in Mexico. Fortunately, the far western Union leaders did not have to fear a large-scale Confederate invasion coming through Canada as they did from Mexico. That bit of good news notwithstanding, the situation along the northern border warranted close observation and precautions to thwart any potential dangers that might arise. The combination of a vocal populace of southerners in both the regional capital, Victoria, on Vancouver Island and in the gold upstart gold towns, combined with an edgy governor, nervous about the influx of Americans chasing gold strikes, had the potential to create any number of problems. Even though, by 1861 relations between political and military officials on both sides of the border were better than they had been in many years, the momentary calm did not entirely assuage decades-old mutual suspicions. Given the uncertainty of the governor's commitment to British neutrality, there existed the strong possibility that he might ignore Confederate sympathizers trying to outfit a raider with which to disrupt United States commerce on the Pacific. Those same sympathizers could, as was proven in eastern Canada, provide a base for paramilitary attacks into Washington Territory. Most frightening, if also most unlikely, of all was that the royal governor might disregard the official British position of neutrality and take matters into his own hands. 
As far-fetched as such potentialities might seem, they were taken very seriously by Department of the Pacific leaders and especially the more easily agitated politicians in the Northwest. Unchallenged American control of the Pacific Northwest, meaning the present states of Washington, Oregon, and the Idaho panhandle, did not begin until 1846, and even then there were numerous unsettled boundary questions. In fact, the question of control of the region almost precipitated a war in the mid 1840s. Acrimony arose anew as late as 1859, when the fragility of a joint occupation of San Juan Island in Puget Sound resulted in a political confrontation of comic proportions. Compounding these regional agitations (with international ramifications) was Canada's role in larger conflicts between the United States and England, which resulted in two wars and two political confrontations that nearly escalated into wars on other occasions in the 85 years prior to 1860. The key to understanding the difficulties facing the Department of the Pacific north of the border, thus, is putting the concerns held by department commanders in the context of the long history of periodic animosity between England and the United States as well as understanding the dangers unique to the region, especially once the war began.

Given the fact that American and British forces had each crossed the Canadian border as part of military operations during two previous wars, concern over what the British might do did not seem that far fetched at the time. In 1775 American colonial forces, led by Generals Philip Schuyler and Richard Montgomery invaded Canada in an attempt to convince the French population to rise up and throw off their British masters. Ultimately, the campaign was a failure. Not only did the French prove more pragmatic than foolhardy by not joining the Americans, whom the British soundly defeated at 
Quebec in December 1775. ${ }^{1}$ Two years later Canada again factored into the active side of the Revolutionary War when British forces commanded by General John Burgoyne marched south out of Canada with the intention of striking Albany, New York, and cutting an eastward swath, thereby isolating New England from the rest of the rebelling colonies. Ultimately, this campaign proved far more disastrous to the British military than the American effort two years earlier had to the colonists. The colonial victory at the resulting October 1777 Battle of Saratoga, and the subsequent surrender of Burgoyne's army, induced the French to join the American fight. Having served as the target of an early American invasion and then as the base of operations for a British attack on the colonies, Canada proved an integral factor in the early part of the American Revolution, with repercussions that affected the outcome of the war.

American wariness of the British presence in Canada did not dissipate with the end of the Revolution in 1783. In fact, supplies for the British forts in the Ohio Valley, that were supposed to be abandoned as part of the Treaty of Paris, came down from Canada. Those supplies included arms for the various Native American tribes, many of whom used them on American frontiersmen. Anxieties caused by the British refusal to abandon its forts in that region, the holding of which was made possible supplies from Canada, did not cause the War of 1812, but they aggravated an already tense situation.

By 1812 the United States was a dramatically different nation than it had been at the outset of the Revolution. Although the country's borders ran from coast to coast ever

\footnotetext{
${ }^{1}$ Despite the defeat of American forces under General Benedict Arnold outside Quebec at the end of the year, other colonials remained in Canada until the following October, clinging to the hope that dissatisfied French subjects would join them. Given the generally broad freedoms enjoyed by the French Canadians along with the wretched condition of the American forces, any hope of taking Canada by force essentially ended in 1775. For an overview of the Canadian campaign see Christopher Ward's classic, The War of the Revolution, 2 vols., (New York: MacMillan and Company, 1952), 1: 135-201.
} 
since the Louisiana Purchase, only a few sparse settlements extended beyond Michigan Territory. The expanded American-Canadian border meant that when the War of 1812 broke out, the potential theatre of operations extended several hundred miles further westward than it had in the 1770s. Just as had been the case at the outset of the Revolution, Americans harbored Canadian aspirations. Unlike the Revolution, however, when Canada represented a potential ally, in 1812 the sole purpose of an advance across the border was to take the fight to the British. ${ }^{2}$

Reminiscent of actions of more than 35 years earlier, American forces invaded Canada at the earliest stages of the war. Victories again proved difficult to achieve in 1812 and 1813. For their part, the British also repeated their Revolutionary experience, marching south from Canada fighting a number of engagements in 1812 and 1813, finally launching a major invasion along the eastern section of the border in 1814. Like the Americans, they suffered the same fate as they had more than 35 years earlier.

In the span of roughly 35 years the relations between the British in Canada and the United States were marked by two wars, in which both sides invaded the other nation, and the intervening years were marked by suspicion, fear, and mistrust. Although relations slowly improved after 1815, the lack of trust, as well as economic competition in the disputed Oregon territory, prohibited relations from thawing completely.

Continued mistrust combined with growing American expansionist sentiments led to rising tension between the British and Americans, tension which reached a critical

\footnotetext{
${ }^{2}$ For a general American political overview of the activity along the border during the War of 1812, see, Reginald Horsman, The New Republic, ( New York, London, San Francisco, Toronto: Longman, 2000), 235-246; for greater detail see, John R. Elting, Amateurs to Arms: A Military History of the War of 1812, (Chapel Hill, NC: Algonquin Books, 1991), chapters three and four, six, nine, and fourteen.
} 
level during the 1844 presidential campaign. James K. Polk based his enthusiastic expansionist candidacy on American braggadocio, political rhetoric, and a Jeffesonesque desire to create an "Empire of Liberty". Polk's campaign platform called for the "reannexation of Texas and the reoccupation of Oregon.” If Polk, after being elected president, followed through on another campaign slogan of “54' 40" or fight," the United States would gain most of what is now British Columbia, to the 54' 40" parallel line, either through negotiations or the use of military force. As much as the notion of trying to seize such a large chunk of Canada seems ridiculous now, the British took the hostile political language quite seriously in 1844, even if they understood Polk had used the Oregon question for political hay. What he would do as president was unclear. Therefore, they were warranted in preparing to defend the farthest western region of Canada from American expansionism.

Despite the heated rhetoric, which served its purpose in helping to get Polk elected, the president-elect retrenched quickly. ${ }^{3}$ Although he spoke boldly about pursuing all of Oregon in his inaugural address, Polk’s initial offer to the British was more restrained. ${ }^{4}$ Like his predecessors, Polk's first proposal to settle the nagging Oregon question was to extend the 49 parallel line all the way to the Pacific Ocean. ${ }^{5}$ In December Polk informed Congress that British officials had refused his offer, which, he

\footnotetext{
${ }^{3}$ Polk had been a relative unknown prior to the 1844 presidential election; therefore, his aggressive expansionist stance played a key role in launching him out of obscurity.

${ }^{4}$ Paul H. Bergeron, The Presidency of James K. Polk, (Lawrence, KS: University of Kansas Press, 1987), 117.

${ }^{5}$ Frederick Merk, The Monroe Doctrine and American Expansion, (New York: Vintage Books, 1966), 73. Merk points out that President Tyler and the lame duck House of Representatives pushed "All Oregon" legislation -meaning to the northern extreme of the Canadian portion of Oregon -but that it died, as expected in the Senate.
} 
told them, was the last time he intended to make such a proposal. ${ }^{6}$ Polk heightened tensions further when he asked Congress to terminate the 1827 joint occupation agreement. As anticipated, the measure passed easily in the House, but was shot down in the Senate. Despite this defeat, the president's actions alarmed the British. In response to the rapidly deteriorating situation, one British official suggested sending naval vessels to both the Puget Sound region and to the mouth of the Columbia River. In March 1845 it appeared the two nations might actually go to war over the unsettled Oregon question. Once again, America’s future was intertwined with British Canada, this time far off on the Pacific coast.

Polk’s boisterous attacks on the British, political posturing, and circumstances along the Mexican border made it expedient to settle the issue quickly and peacefully. Furthermore, the Anglo-American trade was too valuable to both countries to risk conflict in such a far removed region. The British ambassador to the United States passed along his government's offer for arbitration of the dispute along with England's willingness to agree to the $49^{\text {th }}$ parallel line, excluding Vancouver Island. Political wrangling in the U. S. Congress delayed action on the proposal until April, when it agreed to arbitration. The British acceptance of the revised plan reached the capital in June 1846 where it was approved three days later. ${ }^{7}$ Thus, war with England over the Oregon question was averted, as were tensions along the American-Canadian border.

\footnotetext{
${ }^{6}$ Ibid, 78; Bergeron, 119-120..

7 Treatment of the final phase of the Oregon crisis can be found in, Bergeron, 124-13, Merk, 102103, and William H. Goetzmann, When the Eagle Screamed, (New York, London, Sidney: John Wiley and Sons, 1966), 47-48.
} 
As the sectional crisis in America heated up in the late 1850s, relations between Americans and Canadians in the Pacific Northwest once again degenerated into political skirmishing. In fact, events in 1859 included the shedding of British blood, which led to a military standoff between local forces representing both nations. Actions taken on June 15, 1859, resulted in one of the most bizarre episodes in American diplomatic history. The language that settled the Oregon question had been ambiguous about who owned San Juan Island in Puget Sound. That ambiguity resulted in both American and British citizens settling on the island. Given the joint occupancy and lack of either side having a clear title -or control -a conflict seemed inevitable.

At the heart of the growing difficulties were American rights to be on the island at all. The British inhabitants, who outnumbered the Americans until May, were employees of the Hudson Bay Company, and they did not recognize American claims to any part of San Juan Island. One interloping American named Lyman Cutler sparked the international conflict when he took matters into his own hands. After building a cabin, he planted a garden, which he fenced as best he could. Unfortunately for Cutler, freeroaming Hudson Bay livestock easily trampled the garden and uprooted his potato patch. Following unsuccessful complaints to the local Company official, Cutler shot and killed an offending hog, for which he attempted to pay the official. The seemingly justifiable murder of the wandering British pig very nearly ignited a war, or rather the reactions to that event brought England and the United States closer to armed conflict than at any time since Andrew Jackson won the Battle of New Orleans in January $1815 .^{8}$

${ }^{8}$ Information on the origins of the Pig War can be found in Keith A. Murray, The Pig War, (Tacoma, WA: Washington State Historical Society, 1968), 32-33. 
The officer who took over command of the American contingent on San Juan

Island, Captain L.C. Hunt, wrote shortly after the incident subsided,

I am confident that this whole imbroglio is a disgraceful plot involving General Harney, a dull animal, Mr. Commissioner Campbell, a weak, wordy sort of man; Captain Pickett, to some extent, whose main fault perhaps has been bad judgment in allowing himself to be used as a tool by the main conspirators. ${ }^{9}$

Hunt was not alone in his assessment of the origins and motivations behind the Pig War.

Major Granville Haller contended that Harney and Pickett had conspired to ignite a conflict with the British as part of a plot to help the South in its growing political disagreement with the North. Major Haller believed "the hog incident [was] to be seized as the pretext, and exclusion of British troops from San Juan island to become a casus belli." ${ }^{10}$ When Haller met with Pickett he advised proposing a joint occupation to the British authorities, upon which the fire-brand captain informed Haller, "He assured me that if they attempted to land he would fire on them. He believed they would land, and considered war inevitable.”11 Captain Hunt explained immediately after the confrontation that "Nothing has saved us from a bloody collision but the patient dignity and forbearance of the old admiral [British Rear Admiral Lambert Baynes], who had an overwhelming force at hand.”12 Admiral Baynes’ restraint contrasted markedly with the aggressive stance taken by American officers General Harney and Captain Pickett and the British royal governor.

9 Keith Murray, "Pig War Letters: A Romantic Lieutenant's Account of the San Juan Crisis," Columbia, 1 (1987) 3, 17.

10 Granville O. Haller, San Juan and Secession (Seattle, WA: The Shorey Book Store, 1967; original publication date, 1896), 12.

11 Ibid.

12 Murray, 17. 
Although absurd to the point of being ludicrous, the Pig War reflected the level of mistrust that still existed between local Americans and British officials. The erratic relationship foreshadowed potential future unrest in the region. Despite the success of the joint occupancy compromise, due largely to the restraint of the local British administrators, a number of residents, including officials, still mistrusted each other two years later when civil war broke out in America. It was in this atmosphere that pro Confederate elements in what is now British Columbia and Vancouver Island schemed during the war years. In light of the history of periodic cleavages in the relations between Americans and Britons in Canada, made worse by the 1859 Pig War conflagration, Department of the Pacific leaders had to craft policies that addressed all the potential dangers that might lurk north of the border while treading lightly on issues of sovereignty. This was made all the more difficult by the presence of southerners in the two western most Canadian territories.

The reality is that the presence of southerners in the generally favorable environment of British Columbia and Vancouver Island was initially the lesser concern facing Department of the Pacific officials and their counterparts in the Pacific Squadron. At the outset of the war British officials in western Canada alarmed their American counterparts far more than any Confederate sympathizers in the region. Given the varying British attitudes, both in Canada and in England, toward the Confederacy and the withdrawal of United States Army regulars from the Far West (especially along the Canadian border), combined with the volatile situation over San Juan Island just two years before, departmental alarm was understandable. Canada presented the Department of the Pacific (and Pacific Squadron) officials with two significant points for concern: 
first, and certainly potentially the greatest threat, was the danger that if British political policies changed, their military forces might trickle over the United States' northwestern border and, secondly, that Confederate sympathizers would use Canada as a base from which to launch raids south across the border (or at Union shipping interests in the Pacific, namely the gold shipments leaving California).

Washington D.C.'s level of concern can be seen by the fact that an American consulate post was established in Victoria, Vancouver Island, in 1862. There had never been any such consulate in either of Canada's two western territories, nor was there any reason for such a post. Once the war was under way, however, and with British and American relations deteriorating during the brief, but dangerous firestorm created by the Trent Affair in late 1861, the administration quickly dispatched Allen Francis to serve as American consul in the newly-created consulate. He arrived in early April. Francis’ activities far exceeded what was required by his political office. He maintained a network of spies in Victoria employed to keep him abreast of any pro-Confederate activity on either Vancouver Island or in British Columbia (with its transitory population of American miners). ${ }^{13}$

Despite the fears of what might materialize north of the border, officials in Washington D. C. faced more imminent challenges in the East. The result of those dangers was the recalling of most of the regular U.S. Army forces stationed in the Department of the Pacific at the outset of the war. Concerns over potential Indian unrest

13 Information in this paragraph is from Donald F. McLarney, "The American Civil War in Victoria, Vancouver Island Colony,” Unpublished paper, Highline (Washington) Community College, 7-9, and, O.R., 50, 2, 678-79, 682. In a letter to District of Oregon commander, Brigadier General Benjamin Alvord, Francis noted that "I have neither spared time, pains, nor expense in endeavoring to learn what our enemies were doing.” O.R., 682. 
and uncertainty about the political climate in western Canada, kept the regulars from leaving to shore up the eastern armies until relieved by volunteer troops. Initially Californians, but later Oregon troops, were assigned to both the old and some new forts in the department, along with a handful of Washingtonians.

At no place was the departure of U.S. troops more troubling than on disputed San Juan Island. In an effort to ensure that the British did not benefit from the departure of American forces (meaning strengthening their claims to the island), Colonel Silas Casey suggested that the contingent of Royal Marines stationed on the island be withdrawn because the American forces were in the process of departing. The theory being that by doing so neither country would have a stronger claim to the disputed island. The Royal Navy commander for the region, Rear Admiral Maitland, rather bluntly informed Colonel Casey, "we were at perfect liberty to withdraw our force or not as HM's [His Majesty] Govnt. Might think fit.”14 The Royal Marines, all 73 of them, remained on the island, despite the order for the Americans to abandoned Camp Pickett, which would have left the British in control. ${ }^{15}$ Abandoning the American post, however, did not seem prudent to the district commander, who less than ten months earlier had warned Army Headquarters:

For the last twelve months the San Juan imbroglio has only served to keep up a feverish excitement and a hostile feeling between our citizens and those of British Columbia. This feeling will not subside so long as the question of title to the island of San Juan shall remain in abeyance. The slightest provocation from

\footnotetext{
${ }^{14}$ Maitland to Colonial Office, June 22, 1861, British Foreign Office, copies in Library of Congress, Washington D.C.

${ }^{15}$ O.R., 50, 1, 512. The abandonment of the American post on San Juan island, as directed from the department headquarters, is given in District Special Order 9, dated June 11, 1861.
} 
either side might produce a collision, from which the most deplorable results would follow. ${ }^{16}$

Not surprisingly, Wright, who had stressed that "this state of affairs requires prudence and firmness in its management," found a way to countermand the order to abandon the American post. ${ }^{17}$ Using the threat of Native American raids as a pretext Wright gave new orders, nullifying those issued just ten days earlier, thereby ensuring an American presence remained on the island throughout the war. Ultimately, unlike most of the other posts in the Department of the Pacific, where volunteers replaced the professional soldiers, Regular Army forces garrisoned Camp Pickett, San Juan Island throughout the duration of the war.

Two years before the war, during the Pig War imbroglio, three men shared responsibility for the heightened tensions. The department commander, General Harney, and the field commander, Captain Pickett, were the primary sparks in the tinder box, but they had British help. The third person responsible for the brinkmanship diplomacy that nearly resulted in a war was the royal governor, Sir James Douglass. The governor did not want war in 1859, but he was unwilling to suffer any political embarrassments at the Americans’ hands either, and as became clear, he possessed an aggressive streak. This same characteristic led the governor to make a radical proposal late in 1861 in the wake of the political turmoil caused by the seizure of Confederate envoys from the British ship the Trent.

16 Wright to General Scott, August 28, 1860. Executive Documents: The House of Representatives, second session, $36^{\text {th }}$ Congress, 1860-61, 2.

17 Ibid. 
Fearful that the ongoing troop build-up in the Far West would lead American expansionists to take some or all of western Canada, Douglass proposed that the English strike first. To this end he requested two regiments of reinforcements, which authorities in London refused. ${ }^{18}$ Undeterred, in December the pugnacious governor wrote to the British Secretary of State, the Duke of Newcastle, pointing out that at present he had a mere 200 troops (along with four naval vessels) with which to protect far western Canada, should a conflict arise. Despite his numerical weakness, the governor informed his superiors there "was no reason why we should not push overland from Puget Sound and establish advanced posts on the Columbia River." ${ }^{19}$ The idea is not as far-fetched it appears on the surface. Douglas knew that American troop dispositions were in flux and that some northern posts were likely to be abandoned. Furthermore, there was no doubt that the British navy could easily take control of Puget Sound and the Columbia River. The governor assured his superiors, that "with Puget Sound, and the line of the Columbia River in our hands, we should hold the only navigable outlets of the country -command its trade, and soon compel it to submit to Her Majesty’s Rule.”20

In June 1862 newly appointed District of Oregon commander, Brigadier General Benjamin Alvord, feared just such a move by the British in Canada. After taking some time to acquaint himself with his new command, Alvord described his district's vulnerabilities in a letter to Secretary of the Navy Gideon Welles. The note, which was a

18 Robin W. Wink, Canada and the United States: The Civil War Years. (Baltimore: The Johns Hopkins Press, 1960), 158.

19 Benjamin F. Gilbert, "Rumors of Confederate Privateers Operating in Victoria, Vancouver Island,” British Columbia Historical Quarterly, 18 (1954) 3/4, 241. Here Gilbert quotes from Douglas’ December 28, 1861 letter to Newcastle.

20 Ibid. 
barely veiled request for an increased Union naval presence in the region, read as if

Alvord knew what the Royal Governor was thinking, in regard to both his fears about foreigners and his strategy in the event of war between the two. Alvord told Welles,

There is no doubt that the day will come when Equimault Harbor [Vancouver Island] will be the favorite post of the Pacific Squadron of the British Navy. These considerations cannot be overlooked in all the preparations we may make for a period of foreign war. This region is the most remote, the most exposed, and therefore in some respects the most vulnerable of our whole sea-board. ... These discoveries [of gold in Washington Territory] will make the country more inviting to an enemy. ${ }^{21}$

Fortunately for the Union, officials in London did not share Douglas' enthusiasm for a conflict with the United States, especially given Canada's military weakness, nor did they envision the possibilities Alvord saw. Those troops that were eventually allocated for Canada in the aftermath of the Trent Affair were stationed in the more populated eastern region. Given the limited manpower available and unwillingness to strip another part of the empire to shore up Canadian defenses sufficiently, the British in North America maintained a sometimes shaky neutrality during the war. Consequently, Douglas' invasion proposal gained no traction in London. Left with few options but still not entirely trusting the Americans, even after two years of friendly relations with the Department of the Pacific leaders and troops, the royal governor authorized the raising of two volunteer rifle corps to complement the royal marines and engineers stationed in the region, for defense only. ${ }^{22}$

American officials, both in the region and in the capital, never knew of the governor's views. It was believed, however, that he, along with other officials in Canada

\footnotetext{
${ }^{21}$ O.R., 50, 2: 96.

${ }^{22}$ Wink, 162.
} 
sympathized with the Confederate cause. This being the case, it was important to remain abreast of the British military's activities. This task fell to America consul, Allen Francis, whose post, as noted above, had been created so the Americans could keep the pulse of the atmosphere in western Canada. Francis, who worked with both Generals Wright and later Irvin McDowell at Department of the Pacific headquarters (and commander of the Pacific Squadron, Admiral Charles Bell), as well as District of Oregon commander, Brigadier General Benjamin Alvord, went about his task with a dogmatic diligence that bordered on paranoia. He reported everything, no matter how implausible or insignificant. ${ }^{23}$

Throughout the war Francis reported all the news that came to his consulate post in Victoria, little of which, as he found out, had to do with odd or threatening British military activities. Most of his reports focused on insults, schemes, or dangers posed by Victoria’s openly pro-Confederate population, almost all of whom were American expatriates. As it turned out, Francis’ vigilance was rewarded, and as actions taken elsewhere in Canada, as well as activity in California, proved, no matter how far removed from the conflict's main scenes the pro Confederate element did pose a threat to the Union cause.

If the government and military seemed overly concerned about Confederate sympathizers in Vancouver and British Columbia colonies, it must be remembered that a number of similarly desperate plots originating elsewhere in Canada came to fruition during the war. In fact, southern sympathizers and military personnel used Canada as a

${ }^{23}$ Although Francis never mentioned the names of any of his operatives, Victoria Chronicle editor, D.W. Higgins wrote that Francis told him one of them was Dick Lovell, who helped thwart the plan to capture the Schubrick. D.W. Higgins, The Mystic Spring (Toronto: William Briggs, 1904), 123-124. 
base for both land and naval operations. In October 186420 raiders, including a Confederate lieutenant, crossed from Quebec into Vermont, robbing three banks in the small town of St. Albans, getting away with $\$ 200,000$. Although the raiders fled back into Canada before an effective pursuit could be mounted, Major General John Dix authorized his subordinates to "pursue them into Canada if necessary and destroy them."24

Secessionists also carried out naval raids that in one case started in Canada and in another ended there. One month before the St. Albans raid, John Yates Beall and some 20 Confederate agents attempted to capture the U.S.S. Michigan, the sole Union warship patrolling the Great Lakes. The attempt was foiled when one of the conspirators was captured and revealed everything, thus giving Union officials time to prepare their own trap. Beall and his co-conspirators escaped after burning a commandeered ship, which they hoped to use to get close enough to the Michigan to board it and melted into the Canadian wilderness. ${ }^{25}$ Another attempted seizure of a northern naval vessel occurred two months after the failed effort to capture the Michigan. Although 14 Confederate agents were able to seize the Chesapeake, they were unsure of what to do with it, so they sailed to Nova Scotia and abandoned it to the Canadian authorities -who returned the ship to its owners. ${ }^{26}$ Clearly, desperate Confederates and southern sympathizers understood the possibilities of staging operations north of the border, and that was no less

\footnotetext{
24 O.R., 43:2, 422.

25 O.R.N. 3, 352-354.

26 Bruce Hutchinson, The Struggle for the Border (Toronto, New York, London: Longmans, Green, and Co., 1955), 333.
} 
so in western Canada where the atmosphere was at least as sympathetic to the southern cause as it was in the eastern part of the country.

Confederate sympathizers in the Far West posed two possible dangers from their perch in western most Canada. The most likely, and also the most potentially rewarding, scheme they might initiate would be to attack the gold shipments sailing from San Francisco. The far less likely way to strike a blow for the Confederacy would be to organize a raiding force with which to attack Union targets in the northern territories (now Washington and Idaho). Given the South's desperate need for gold with which it could purchase supplies in Europe, Confederate sympathizers in Victoria eventually attempted to acquire and outfit a raider, whereas there was no attempt to launch landbased raids across the border.

Ever since the 1858 Fraser River gold rush, thousands of Americans had been roaming the rivers and creeks of British Columbia in search of gold. Inevitably, few found the wealth they sought, and while most drifted back across the border, many remained in Canada. By the outbreak of the Civil War Victoria, Vancouver Island, was home to a thriving southern population. The editor of the Victoria Chronicle noted: "Shortly after the outbreak of the war many sympathizers with the Slave States came to reside in Victoria. Some leased residences, others took apartments at hotels, still others went into business while a fourth class proceeded to Cariboo and engaged in gold mining and trading."27

The early Confederate successes emboldened the city’s southern enclave, the wealthier of which gathered in the rooms of two Alabama brothers, John and Oliver

\footnotetext{
27 Higgins, 107.
} 
Jeffries, at the St. Nicholas Hotel, where they "became noisily jubilant."28 Chronicle editor D.W. Higgins, whom the southerners considered a loyal friend, remembered celebrating one "great rebel victory, and the company excelled all previous efforts in singing Confederate airs, while their rebel hearts, bursting with enthusiasm, found frequent vent in loud cheering.”29 Not long after assuming his post, Consul Francis informed his superiors about the overtness of Confederate sympathy displayed in Victoria.

As the residents prepared to celebrate the Prince of Wales' birthday with a twoday extravaganza on November 9 and 10, 1862 southern sympathizers seized that very public opportunity to display their predilections by raising a Confederate flag. Francis informed Secretary of State William Seward that a number of northern residents urged him to protest the affront, which he did, but Governor Douglas chose not to respond to the American official until two days after the celebration ended. ${ }^{30}$ Governor Douglas’ lackadaisical response to Francis’ protest led some to assume such actions would not only be ignored, but openly tolerated. ${ }^{31}$ The flags, which soon flew over a number of homes throughout Victoria, remained a troubling (and insulting) issue until near the end of the war. As the governor of Washington Territory informed Secretary of State Seward in July 1864, "the officers and crew of every American Vessel that enters the Harbor of Victoria is insulted, \& indignant, at the sight of the Rebel Flags flying in Victoria.” Of

28 Ibid.

29 Ibid, 111.

30 McLarney, 17-19. Here the author cites a November 13, 1862, dispatch from Douglas to Francis in which the Royal Governor claimed to be unaware of any such flag having been raised during the celebration.

31 Ibid, 20-21. 
course, there was little Seward could do beyond putting political pressure on the British ambassador in Washington; the Department of the Pacific officials could do even less. ${ }^{32}$

The southern presence in Victoria was large and open enough that in 1863 one J.S. Shapard, who had been at the heart of the flag incident the previous year, opened a new watering hole named the Confederate Saloon. ${ }^{33}$ This establishment soon became the meeting place of a group of roughly 50 southerners who called themselves the Southern Association. ${ }^{34}$ This bar, and its churlish proprietor, quickly became a thorn in American Consul Allan Francis’ (the would-be spy master) side.

This was the prevailing climate in Victoria, which worsened when large numbers of the miners fled the snows that descended upon the gold fields beginning in the fall. As Consul Francis informed his brother, a major at Fort Vancouver, Washington Territory, “The miners are now coming down from the upper country, generally in desperate circumstances, mostly secesh, and ready for anything.”35 In such an atmosphere, where the official neutrality stance at times seemed blindly apathetic, Confederate sympathizers pursued a number of schemes, all with the intent of disrupting trade, particularly the shipment of gold from San Francisco to the East, via Panama, during the first three years of the war.

It took time for Victoria’s growing southern community to seize upon an idea of how best to aid the Confederate cause from so far away. However, during the seemingly calm time, which lasted until early 1863, there was plenty to celebrate, which, as editor

\footnotetext{
${ }^{32}$ Quoting Pickering to Seward, July 5, 1864, Territorial Papers, Washington Series, in Ibid, 43.

${ }^{33}$ Ibid, 31.

${ }^{34} \mathrm{Ibid}, 37$ and 38.

${ }^{35}$ O.R., 50:2, 678.
} 
Higgins noted, they did. As Confederate victories mounted in the East, southern sympathizers like the Jeffries brothers decided that the best way to assist the southern cause was to disrupt Union commercial efforts along the Pacific Coast. Of course, the gold shipments were the ultimate prize, but other Union targets plied the northern Pacific waters as well.

Before any attempts to attack Union commerce in the north Pacific could take place, however, local southern sympathizers needed a boat capable of being outfitted as a raider. This proved to be a serious impediment to the privateers' visions of glory and plunder. The ship the conspirators hoped to capture was the U.S.S. Shubrick, which one old pioneer described as "a handsome sidewheel steamer, far from slow for those days, perfectly seaworthy and safe for ocean navigation, carried four or five brass cannon, and had a good supply of small arms, ammunition, etc.”36 Designs to capture the Shubrick, however, fell apart, "for the want of a leader in whom the banditti could confide," as Francis informed Captain Thomas Selfridge, the commander of the navy yard on Mare Island, California. ${ }^{37}$ This failure forced the conspirators to come up with a new plan.

The next effort played out in the pages of Victoria’s two newspapers, the Chronicle and the Colonist. That it did is symbolic of the difficulties facing Consul Francis and his operatives in Victoria. Until the Confederate sympathizers actually violated England's official neutrality policy there was nothing he could do. Unless they crossed into American waters or lands, Francis knew the local officials were not paying

${ }^{36}$ Charles Prosch, Reminisces of Washington Territory (Fairfield, WA: Ye Galleon Press, 1969), 52.

37 Official Records of the Union and Confederate Navies in the War of the Rebellion (Washington, D.C.: Government Printing Office, 1896), series I, volume 2, 258. All other references to the naval records of the war are for series 1 , unless otherwise noted, and will be cited as ORN. 
very close attention to the southerners' machinations. On February 4, 1863, the Chronicle published an article declaring that a Confederate navy officer had been in Victoria for a month. His reported purpose was to purchase an English ship, the Thames, which he was to man with local sympathizers and then set out to capture San Francisco gold shipments. ${ }^{38}$ Ultimately, as the Chronicle reported, the plan failed due to a lack of funds, which seems odd considering the presence of a number of southerners leading rather ostentatious lives in Victoria. ${ }^{39}$ The failure of this second plot illuminates two points about Confederate sympathizers in western Canada. First, that no one was jailed, or even investigated, for very public efforts to violate English neutrality laws make it clear they had little to fear from the Canadians/British authorities. Secondly, despite their confidence in themselves, disorganization and bad luck, and Allen Francis and his agents, plagued the southern expatriates.

Although he had taken no public action, Consul Francis kept Secretary of State Seward apprised of developments, thanks to his operatives. As Francis told the Chronicle's editor once that particular danger passed, "I knew what was going on all the time. My detectives kept me well informed. ${ }^{40}$ Whether or not there was much truth to this particular story is difficult to ascertain, but it kept the competing papers busy postulating on the veracity of the story; the Chronicle believed it and the Colonist did not. Furthermore, the entire episode served to demonstrate how the Americans navigated the complex diplomatic seas when trying to prevent Confederate sympathizers (or actual

\footnotetext{
${ }^{38}$ Gilbert, British Columbia Historical Quarterly, 241.

39 Ibid, 242-243.

${ }^{40}$ Higgins, 124.
} 
Confederates, for that fact) from using far western Canada as a base from which to launch attacks on the United States or Union interests at sea. Regardless of the truth of this or any other story, the American consul's job was to warn the Department of the Pacific and Pacific Squadron leaders and inform Secretary Seward, and those individuals would then take the appropriate actions to thwart the enemy's actions.

Although Francis does not seem to have been particularly alarmed by the Thames rumors, he dutifully kept all the principle leaders informed. The Thames story gained increased currency after March 15, 1863, and forced officials in Washington D.C., and its military leaders (both land and sea) on the Pacific Coast to respond. On that day, civil and military officials in San Francisco seized the S.S. Chapman, which had been outfitted as a privateer and was about to leave the harbor when it was captured. ${ }^{41}$ Two boats full of armed seamen from the U.S.S. Cyane, which protected San Francisco harbor at General Wright's request, captured the would-be raider and its crew of 21without a fight. After boarding the vessel, San Francisco police, working with the Customs Collector, Ira Rankin, discovered "a number of guns, ammunition, and other military stores were found on board." ${ }^{42}$ The capture of the Chapman conspirators set off an alarm from San Francisco to Puget Sound, and was felt by Union leaders in Washington D.C. as well.

The capture of a privateer in San Francisco harbor, with well-developed plans for attacking the gold shipments, led Secretary of State Seward to re-evaluate Consul Francis' report about the Thames uproar that had dominated the Victoria newspapers for

41 O.R., 50:2, 352.

42 O.R.N., 2, 122. For the purposes of this chapter the sketch of the Chapman affair has been kept to a minimum since it was examined more fully in an earlier chapter. For General Wright's version of events, see O.R., 50:2, 363-64. 
the first two weeks of February. With Francis having done his job by informing Seward and the military officials on the Pacific Coast, responsibility to act fell to Seward. For whatever reason, the Secretary of State initially chose to do nothing; that changed, however, with the capture of an armed and manned privateer in San Francisco, the city where the federal military authority was headquartered. Given the heightened concerns about the Confederate threat to Union shipping, Seward sent a letter on March 31 to the British ambassador to the United States, Lord Lyons, stating:

I regret to inform you that reliable information has reached this department that an attempt was made in January last, at Victoria, Vancouver's island, to fit out the English steamer Thames as a privateer, under the flag of the insurgents, to cruise against the merchant shipping of the United States in the Pacific. Fortunately, however, the scheme was temporarily, at least, frustrated by its premature expose. $^{43}$

In addition to drawing Lord Lyons' attention to the topic, Seward applied his considerable diplomatic pressure to the British ambassador and asked "the attention of her Majesty's colonial authorities to the subject, in order that such violations of the act of Parliament and of her majesty's proclamation may not be committed." 44 In other words, Seward expected the British government to force its representative in western Canada, Governor Douglas, to enforce the neutrality policy.

Diplomatic pressure alone was not enough to assuage Francis’ fears or General Wright's concerns. ${ }^{45}$ In an effort to take more aggressive steps to protect Union

${ }^{43}$ Seward to Lyons, March 31, 1863. House Executive Documents, $1,38^{\text {th }}$ Congress, $1^{\text {st }}$ Session: $1,535$.

${ }^{44}$ Ibid.

${ }^{45}$ In reality, Brigadier General Benjamin Alvord, District of Oregon commander, had been more vocal in his calls for a stronger naval presence in Puget Sound -and at the mouth of the Columbia River. He sent his first request for naval reinforcement to the Secretary of the Navy in September 1862. O.R., 50:2, 96. 
shipping, The U.S.S. Saginaw was ordered from San Francisco to Puget Sound, “without any unnecessary delay, to the ports Angeles and Townsend, in Washington Territory, to Victoria, in the British Possession, on Vancouver Island . . . f for the purpose of obtaining information from the authorities, and from other sources, in relation to the equipment of rebel privateers in those waters."46 The combination of the presence of a Union military vessel patrolling Puget Sound and the blow to Victoria's would-be privateers' morale (caused by the news of the capture of the Chapman) quieted pro southern rumblings on Vancouver Island, but only briefly.

Despite the set-backs, the Southern Association continued to meet, and brew desperate schemes amid drinks at the Confederate Saloon. As Francis informed the naval commander at Mare Island, “There is still in this city a rebel organization, which has had several meetings within the last few weeks. They are awaiting, it seems from rumors, the receipt of letters of marque from the President of the so-called Confederate States.” ${ }^{47}$ Once again, Francis’ agents had done their task well. The association’s president, Jules David, had indeed submitted a request to the Confederate government in Richmond to officially recognize the effort to begin operations of a privateer for the South. David, on behalf of the association, requested the all-important letters of marque in April 1862, but Richmond did not respond.

Having heard nothing for over a year, David again requested letters of marque in October 1863. In this second note he attempted to convince Confederate officials

${ }^{46}$ O.R.N., 2, 165.

47 Ibid, 260. The letters of marque were official documentation that proved that those privateers holding the letters were operating on behalf of a specified government -the Confederacy in this case -and were therefore not pirates, but sanctioned military forces. 
(Confederate Secretary of State, Judah Benjamin received the letter) of the association's earnestness and the possibilities for success by writing:

It is our most anxious wish to do something for our country, and we can not serve her better than in destroying the commerce and property of our enemies. If you will for a moment reflect upon the extensive commerce of the Federal States with South America, California, the islands, China, and Japan, you can well imagine what a rich field we have before us. ${ }^{48}$

David further explained "We have at our disposal a first-class steamer of over 400 tons, strongly built, and of an average speed of 14 miles. The money required to arm her and fit her out as a privateer will be raised without difficulty amongst our friends here.”49 The ploy worked, but in the wrong circles. With the war now going against the South, Confederate officials in Richmond did not consider the desperate scheme, and once again chose not to reply. However, the ever-vigilant American consul, Allen Francis, responded in his own way.

In a rather odd twist, Francis, who, through the efforts of his operatives knew that much of what David told Benjamin was true (although there is no indication that Francis knew about the letter), chose to inform his brother, Major Simeon Francis, instead of the proper military authorities. ${ }^{50}$ Once again proving just how well informed he was about the Confederate sympathizers' activities, Consul Francis described very accurately the Southern Association's plans. He informed his brother that ever since a very fast 300ton, all steel, ship had arrived in Victoria the "rumors have been rife that the rebels have

${ }^{48}$ O.R.N., series 3: 1, 934.

${ }^{49}$ Ibid.

50 The consul could have written to either General Alvord or Alvord's superior, department commander General Wright, or the senior naval officers -Pacific Squadron leader Admiral Charles Bell or Captain Thomas Selfridge at Mare Island. 
been trying to buy her for a privateer." ${ }^{\text {51 }}$ Major Francis understood the significance of the letter, but since he was not at his post when it arrived, a month passed before he turned the communiqué over to district commander Alvord-on November 20.

General Alvord responded immediately to Consul Francis. After rebuking the diplomat for not informing the proper authorities, Alvord reassured Francis that he had requested naval reinforcements for Puget Sound months earlier. Alvord also informed the consul that he had passed the contents onto General Wright's headquarters, with the assumption the department commander would take action. ${ }^{52}$

Alvord was correct, Wright immediately took steps to strengthen the U.S. military presence in the waters of Puget Sound by requesting that Captain Thomas Selfridge, naval commander at the Mare Island Navy Yard, send a man-of-war to the region. ${ }^{53}$ Unfortunately, the only possible naval vessel suited for the task was the U.S.S. Narragansett, which needed both repairs and additional men to fill out its crew to a serviceable contingent. ${ }^{54}$ After being assigned men from the U.S.S. Saginaw, the Narragansett sailed for Puget Sound on December 11. Finding no privateer activity in the region, the ship returned to San Francisco and underwent more extensive repairs by March 1864. ${ }^{55}$

\footnotetext{
51 O.R., 50, 2: 678.

52 Ibid, 679-680.

${ }^{53}$ Ibid, 684.

${ }^{54}$ Gilbert, British Columbia Historical Review, 252; O.R.N., 2, 574.

55 O.R., 50:2, 789.
} 
The onset of winter seems to have sapped much of the Confederate sympathizers' eagerness to acquire a privateer and their diminished commitment to begin anew in the spring. Richmond's failure to acknowledge the request for letters of marque combined with the South's deteriorating fortunes only exacerbated the erosion of the southern sympathizers’ privateering dreams. In 1864 Governor Douglas was replaced, and the new governor, Arthur Kennedy, proved more cooperative when enforcing British neutrality and discouraging Victoria's southern element's clandestine schemes. Although little life remained in the Confederacy by late 1864, a few ardent members of the Southern Association continued to meet in Shapard's bar. There they still talked about attacking U.S. commercial interests on the Pacific. However, the ubiquitous Consul Francis confidently informed the new Department of the Pacific commander, Irvin McDowell, in late November, "Governor Kennedy will do all in his power to prevent them from fitting out any vessel on this island." ${ }^{, 56}$ In 1865 the Southern Association’s constant scheming fell silent as even the most ardent southern sympathizers realized their own obstacles were too steep and the cause which they hoped to aid was crumbling.

By 1865 diplomatic relations between the United States and Great Britain had long since improved from the early days of the war. For the Department of the Pacific and the Pacific Squadron relations with the British in western Canada and on the waters off the Pacific Northwest coast were relaxed, and in many cases cordial. The new royal governor on Vancouver proved more amendable in allaying American concerns about southern sympathizers, and the only problems on San Juan island were caused by the

${ }^{56}$ Ibid, 1061. 
confusion over police authority, a point that both American and British military personnel took great pains to work out together.

Despite Canada's central place in the history of the spasmodic animosity, and war, between the United States and England, British forces never crossed the far western Canadian-American border, nor did Confederate forces or southern sympathizers successfully use the country as a base of operations for attacks on the United States during the Civil War. The danger was genuine, and the potential damage to the Union effort significant (successful attacks on the gold shipments alone might have prolonged the war). However, through a multilayered effort that started with American Consul Allen Francis knowing the enemy’s schemes, and ending with the Department of the Pacific, and, particularly, the Pacific Squadron stopping any land or sea threats, the Union was spared any threat from southern sympathizers holed up in western Canada. Francis and Department of the Pacific commanders Wright and McDowell performed equally successful and important work through their restrained political dealings with Governor Douglas, thereby ensuring the trigger-happy governor did not cause a political row that could have grown into a pretext for British military (primarily naval) actions against the U.S. forces and interests in the region.

In short, the failure of any threats to the Union to originate in western Canada, be they Confederate sympathizers or British military forces, conveys the false impression that no danger ever existed, and denies the land and sea personnel, and especially Allen Francis and his agents, the credit they deserve for preventing another Anglo-American crisis in the Pacific Northwest. As with the Department of the Pacific's other responsibilities, defusing any threats from Canada became more complicated with the 
onset of the Civil War, but its leaders and troops (along with their brethren in the navy and allies at the consulate) rose to the challenge. 


\section{CHAPTER}

$$
-5-
$$

\section{DISSATISFIED SPIRITS, REPUBLICANS, IMPERIALISTS, AND OTHER DANGERS ALONG THE SOUTHERN BORDER}

On January 8, 1865, General of the Union Army U.S. Grant sent a unique

message to Major General Irvin McDowell, who had commanded the Department of the Pacific since the previous June. The communiqué was not an order but a warning. From his City Point, Virginia, headquarters Grant advised McDowell to remain watchful of “a rebel of the most virulent order” then on his way to the Mexican state of Sonora. The presence of Confederate officials in Mexico was not a new matter. In fact, not long after the war started the Confederate government sent John T. Pickett across the border in an effort to gain recognition, if possible, from the neighboring nation, and if that failed, to at least acquire arms. Fortunately for the Union government, Pickett's lack of tact and an alcohol-fueled display of ill temper landed the envoy in a Mexican jail and terminated the mission. ${ }^{1}$

The situation in 1865, as Grant rightly noted, was different. According to rumors, William Gwinn left an unsuccessful Confederate mission in France, which sought recognition of the southern states, to assume the governorship of Sonora under Emperor Maximillian. ${ }^{2}$ Gwinn warranted extra attention because of his connections in California,

\footnotetext{
1 John T. Pickett, "Letter From Colonel John T. Pickett, of the Southern Confederacy, to Senor Don Manuel de Zamacona, Minister of Foreign Affairs, Mexico,” Hispanic American Historical 2 (1919), 611; Anthony Raymond Salazar, "The Role of the American Civil War in the French Intervention in Mexico and its Impact on Relations with Mexico, 1861-1867,” (Master's thesis, University of Oregon, 1991), 14.

2 Secretary of State Seward informed General McDowell that it appeared Gwinn "has been appointed an agent of the French Government in Sonora." War of the Rebellion, A Compilation of the
} 
which he served as a United States senator until 1861. As he informed McDowell, Grant worried Gwinn would "entice into Sonora the dissatisfied spirits of California, and if the opportunity occurs organize them and invade the State [California].”3 This was indeed something to be concerned over.

January, however, was not the first time Grant expressed his concerns about how affairs in Mexico might endanger the Far West. In late July 1864 Secretary of State William Seward visited the commanding general in the field as Grant's forces initiated the long siege of Petersburg and Richmond, Virginia. When Grant turned one of their conversations onto the subject of Mexico, he, according to his aide, Lieutenant Colonel Horace Porter, told the Secretary, “while we don’t want another war on our hands before we finish the present one, yet I feel that the reestablishment of [a] republican government in Mexico would really be part of our present struggle.”4 The general was, Porter believed, "a staunch supporter of the Monroe doctrine generally, and was opposed on principle to any European monarchy forcing its institutions upon an American republic.”5 Grant’s concerns extended beyond his “deep sympathy for her [Mexico] people in their present struggle,” but also included the potential invasion of the United States by Confederate forces that might gather in Sonora, supported by "officials of the usurpers of the Government of Mexico.”6

Official Records of the Union and Confederate Armies, (Washington D.C.: Government Printing Office, 1897), 50, 2: 873.

${ }^{3}$ Ibid, 1118.

${ }^{4}$ Horace Porter, Campaigning with Grant, (New York: The Century Company, 1897), 256.

5 Ibid, 255.

${ }^{6}$ O.R., 1118. 
Grant was just one of a host of Union military leaders and political officials concerned about affairs in Mexico. From the war's outset, Mexico garnered a significant amount of attention. For the better part of the first two years of the war the Union government viewed Mexico as a passive player in the ongoing civil war on the American side of the border. From the war's outset, Department of the Pacific commanders kept a watchful eye on the northwestern Mexican states to see if the Confederates might use them as a highway from which to attack western New Mexico Territory and California. Shortly thereafter, a number of Union officials pondered the possibilities of employing the same strategy, but in reverse, and thus using the same region to launch their own attack, aimed at Texas. The Department of the Pacific's interest in affairs below its border changed later as the crisis in Mexico spun out of control and French forces took up the imperialistic effort that eventually established Austrian Archduke Maximilian as emperor. That drawn-out struggle incited a good deal of apprehension among Union officials on both coasts. The nearness of an imperial usurper was just the latest anxiety emanating from Mexico during the Civil War. In addition to previous concerns, Union officials in general, and Department of the Pacific personnel in particular, prepared not merely for a threat coming through Mexico, but one originating from the nation, as well as a Confederate danger in Mexico. Over the duration of the war, guarding against a variety of dangers from Mexico proved a complicated and much discussed responsibility for the farthest western Union troops.

Hearing about a potential Confederate threat from northwestern Mexico, on June 28, 1861, General Sumner warned the Fort Yuma commander, Major Albermarle Cady, 
about a possible movement of Confederate troops south of his position. As he told the major,

a rumor is prevalent in this community and the State generally that the so-called government of the Confederate States purpose sending from the State of Texas or elsewhere, through certain States of the Mexican Republic, to this coast a military force, considerable in numbers, with the object of seizing upon and holding the port of Guaymas, in the Republic of Mexico. ${ }^{7}$

As Sumner learned after two months as the Department of the Pacific commander, the only thing more prevalent in the region than gold were rumors. Despite admitting he did not know "whether this is merely an idle rumor or is really the purpose and intention of that people," he felt anything was possible, given "the unparalleled audacity which has characterized the operations of those now in revolt."

Although it is uncertain whether or not he shared U. S. Grant's sympathy for the Republic of Mexico, Sumner's concern in June 1861 was certainly more pragmatic than ideological. With the Union navy blockading southern ports, the Confederacy needed access to international shipping from elsewhere. Clearly, the idea of running a tenuous supply line across the unforgiving lands between the port of Guaymas, on the northwestern coast of Mexico, and Texas was hardly ideal, but it could give the Confederacy something it desperately needed -- ocean access -- as well as a concentration point for an invasion of California. For these reasons alone, Sumner gave the rumor of Confederate designs on the port genuine attention.

As events transpiring in New Mexico Territory demonstrated, Sumner's concerns were well-founded. Confederate success in the Southwest mirrored the successes

\footnotetext{
${ }^{7}$ O.R., 50, 1: 524.

8 Ibid.
} 
elsewhere in 1861. Four days after the Confederate victory at Manassas, Virginia, elements of the Second Texas Mounted Rifles defeated Union Regulars near the town of Mesilla on the New Mexico Territory -Texas border. The following day those Confederates, commanded by the gruff former Texas Ranger, Colonel John R. Baylor, took possession of Fort Fillmore and most of its supplies. On July 27 the Texans captured the garrison's Union force, then in the process of a poorly conducted northern retreat. ${ }^{9}$ Fortunately for the Union presence in the Southwest, and maybe the Pacific, Baylor could not stretch his force, which numbered roughly 250 horsemen, any thinner, and therefore had to suspend any further offensive actions. ${ }^{10}$ Even though Baylor's surprising campaign came to a standstill in less than a month, others shared his vision for Confederate control of the Southwest, and beyond.

The desire to follow up on the early successes in New Mexico Territory ultimately led to the organization of an expeditionary force headed by Brigadier General Henry H. Sibley. Sibley, who served in the Far West and Southwest in the years prior to the Civil War, met with Confederate President Jefferson Davis during the summer of 1861. ${ }^{11}$ In those meetings, he advocated conquering New Mexico Territory, where he expected to find the small Caucasian population supportive of the Confederate cause (the Hispanic population, most of whom had only been Americans since the Treaty of Guadalupe Hidalgo was apathetic at best, and the Native Americans were generally

\footnotetext{
${ }^{9}$ O.R., 4, 16-17.

${ }^{10}$ Ibid, 17.

${ }^{11}$ Alvin M. Josephy, The Civil War in the West, (New York: Alfred A. Knopf, 1991), 52.
} 
openly hostile). On July 8, the Confederate Adjutant General, Samuel Cooper, informed Sibley,

In view of your recent service in New Mexico and knowledge of that country and the people, the President has intrusted you with the important duty of driving the Federal troops from the department, at the same time securing all the arms, supplies, and materials of war.... If successful in accomplishing the objective herein indicated, the President directs that you will, in the exercise of a sound discretion, proceed to organize a military government within the Territory, the detail of which you will submit to him at the earliest possible moment. ${ }^{12}$

Although an analysis of Sibley’s New Mexico campaign is beyond the scope of this study, it is important to understand the general goals of the Confederate advance into the Southwest and examine those actions that bore directly on the Department of the Pacific. In August, upon his return from meeting with President Davis, Sibley began recruiting his expeditionary force in Texas, where he established his headquarters in San Antonio. By late October, the first elements of what Sibley soon designated the Army of New Mexico left San Antonio for the Texas -New Mexico Territory border. ${ }^{13}$ Just what Sibley planned or hoped to achieve after conquering New Mexico Territory (now the current states of New Mexico and Arizona) is unclear, but according to his ranking artillery officer, Trevanion T. Teel, “The objective aim and design of the campaign was the conquest of California, and as soon as the Confederate army should occupy the Territory of New Mexico, an army of advance would be organized, and 'On to San Francisco’ would be the watchword.”14 In pursuing this goal, Sibley directed Confederate agents to "negotiate with the governors of Chihuahua, Sonora, and Lower

12 O.R., 4, 93.

13 Josephy, War in the West, 56.

14 Trevanion T. Teel, “Sibley's New Mexico Campaign - Its Objectives and the Causes of Its Failure,” Johnson and Buel, Battles and Leaders of the Civil War, 2 (INFO) 700. 
California for supplies, etc." ${ }^{15}$ Colonel Baylor, who remained the Confederate point man, and governor of the recently-created Arizona Territory, felt augmenting the small Confederate force would be easy: "I am convinced that a strong force stationed in Western Arizona would enable us to get hundreds of good Southern men, well armed and mounted, who are anxious to join our cause.” ${ }^{16}$ Whether or not Richmond shared these grand designs, the Confederate leaders in the region had designs on the territory abutting the Department of the Pacific, and dreams of reaching California, for as Teel noted, "California had to be conquered, so that there would be an outlet for slavery." 17

Department of the Pacific officials did not have the luxury of knowing whether Sibley's plans ended with New Mexico or included California as well, so they responded appropriately. The first step was to reinforce the department's most exposed post, Fort Yuma, California. The fort, which overlooked the Colorado River, sat in the southeastern-most section of the state astride the California - New Mexico Territory (soon to be Arizona Territory) border. In late September, when rumors of Sibley's efforts to raise an invasion force reached the coast, General Sumner ordered two additional companies from Los Angeles to reinforce the fort. At the same time, he made it very clear what he expected of Lieutenant Colonel George Andrews, who assumed command at Fort Yuma from Colonel Cady, writing him that "under no circumstances whatever will any regular force in this military department surrender to the rebels." ${ }^{18}$
${ }^{15}$ Ibid.
16 O.R., 50, 1: 717.
17 Teel, Battles and Leaders, 2, 700.
${ }^{18}$ O.R., 50, 1: 600. 
While the Department of the Pacific shored up its most exposed command, Army headquarters in Washington D.C. began marshalling scattered forces to put a stop to anything the Confederates might send into the Southwest. Part of this plan included sending a large force of California volunteers, commanded by veteran Colonel James $\mathrm{H}$. Carleton, to attack from the west while other elements, namely those under the overall command of Colonel E.R.S. Canby, which included regulars as well as New Mexico and Colorado volunteers, confronted the Confederates in eastern New Mexico Territory. Well before Carleton's command, termed the "California Column," reached Sibley and the main Confederates, Canby's troops fought the invaders at the battles of Valverde and Glorietta Pass in February and March 1862. After losing his supply wagons during the latter battle, Sibley began a desperate retreat back to Texas.

Despite the Union victory over the main Confederate force in eastern New Mexico Territory, a contingent of southerners probed as far west as Tucson, which they captured. Chasing off this band of southerners fell to the Californians, which included the $1^{\text {st }}$ California Infantry and the $1^{\text {st }}$ California Cavalry Regiments. On April 15, Confederate pickets defeated Union advance riders sent out from Fort Yuma at Picacho Pass, just 80 miles from the California border. After winning the war's western most confrontation between organized Confederates and Union troops, the southerners retreated before the main elements of the California Column reached Tucson, which they recaptured on May 20. ${ }^{19}$ The Californians pressed ever eastward throughout the summer and, with Canby's forces, eventually retook all of New Mexico Territory and took up posts in western Texas. Any future Confederate schemes to capture New Mexico or

${ }^{19}$ Richard Orton, Records of California Men in the War of the Rebellion, 1861-1867, (Sacramento, CA: State of California, 1890), 47. 
press into California required either confronting the enlarged Union military presence in the region or using Mexico as a means to circumvent those troops, by falling in behind them. The troops from the Department of the Pacific played only a minor role in turning back the Confederate invasion, but their presence hastened the Confederate retreat and served as a strong deterrent for the remainder of the war.

Although the eventual route of the southerners under Sibley significantly reduced the immediacy of the danger of a Confederate force entering northwestern Mexico, the threat did not subside until Union troops established permanent posts in New Mexico and Arizona Territories. The frequently shifting authority in western Arizona, between the Departments of the Pacific and New Mexico, further complicated protecting the area. Despite the ousting of all major Confederate forces from the region by fall 1862, Confederate dreams of a far western empire persisted. As Union Brigadier General J. R. West wrote from Arizona Territory in December 1862, "the rebels continue to plot and practice against us in El Paso and throughout certain portions of Chihuahua." ${ }^{20}$ West summed up the frustration facing all the commanders in the Southwest and Far West, noting, "that although the enemy may not advance as lately threatened, we are liable to be diverted from really serviceable duties by constant alarm of his intention to invade the Territory."21 West's statement was an uncharacteristically honest admission about the realities of guarding the Departments of the Pacific and New Mexico. That a handful of bedraggled Confederates managed to get within eighty miles of the California border cast tall shadows for a long time to come. The spectre of Confederates marching westward
${ }^{20}$ O.R., 50, 2: 245.
${ }^{21}$ Ibid. 
across the New Mexico desert or up from the Mexican state of Sonora continued to haunt regional Union officials, who remained vigilant against such a move.

Despite concerns about the potential violation of Mexican sovereignty, Union officials -in Washington D.C. and elsewhere- did not hesitate to propose a reverse version of the Confederate plan as a quick means to invade Texas. In early August 1861 suggestions that the military resources in the Department of the Pacific, including the recently requested volunteer regiments, be put into action came from two unusual sources. Writing from his Western Department headquarters at St. Louis, the Pathfinder, Major General John C. Fremont suggested to Secretary of War Simon Cameron that a force "should be drawn from the Pacific States, and should be composed largely of artillery and cavalry, and should be moved by steamer to Guaymas, and thence by land to its destination [El Paso]”. ${ }^{22}$ Such a move, if successful, would draw Confederate forces away from Fremont, whose command suffered a stinging defeat four days after he composed this message. ${ }^{23}$

Early in the war, interest in Mexico expanded beyond the initial concern that Confederate forces would acquire a seaport on Mexico’s far western coast. In the late summer, Union officials pondered the different possibilities suggested by officers such as Fremont and Major General George McClellan. Those who knew the land, primarily from the Mexican-American War, understood that the western coast of Mexico offered more than one port from which to launch an invasion of Texas. Of course, getting the troops ashore in Mexico was the easy part, trekking across the inhospitable Mexican

22 O.R., 3: 428

23 Troops from his department, under Brigadier General Nathaniel Lyon, suffered a defeat at the August 10, 1861, battle of Wilson's Creek, where Lyon lost his life in the process. 
desert was another matter. However, excitement over any offensive plan in those dark days for the Union led promoters to downplay that formidable obstacle, and as a result the idea grew into a plan in August.

As the summer heat reached its apex, the Union high command formulated a radical course of action for the Department of the Pacific. With nothing more than rumors of Confederate troops anywhere near northwest Mexico, the time was right for a Union offensive in the region. Despite identifying the rumored Confederate designs on a western Mexican port as desperate, Union officials failed to recognize the irony of proposing essentially the same plan, but in reverse. In fact, the idea of using Mexican territory as a throughway for their own invasion, not only failed to cause pause for reflection, but it garnered support at Army headquarters. ${ }^{24}$ Rather than waiting for the Confederates to execute their own designs, the War Department ordered Sumner to initiate the Union version of the same plan.

While still reeling from the devastating defeat of Union forces along Bull Run, Virginia, the commanding general, Lieutenant General Winfield Scott, sent a brief note to his most distant commander. In that August 16 message, Scott informed Sumner that he was "to command an expedition into Texas, via Mazatlan, to be composed of two batteries and ten foot companies of regulars, one regiment of volunteer cavalry, and four regiments of volunteer infantry." 25 Clearly, the War Department meant this to be a major endeavor. More detailed instruction came from the Adjutant General's office, which informed Sumner he was "to fit out an expedition in San Francisco, preparing for
${ }^{24}$ Ibid, 524.
${ }^{25}$ Ibid, 572. 
embarkation thence the necessary supplies and land transportation, to land at Mazatlan and march thence to Western Texas to regain the public property in that state and to draw off insurgent troops from Arkansas, Missouri, \&c.”26 Whether by design or not, this plan mirrored Fremont’s earlier proposal.

Union forces could not simply march through a sovereign nation, however, even if they intended to leave those lands as quickly as possible. Secretary of State William Seward contacted the Mexican representative in Washington D.C., Matias Romero, who passed the bold request onto his superiors. On August 26 Romero informed Seward that the Republic of Mexico granted the United States military the right of passage through northern Mexico. Aware of its mounting international problems, Romero hoped the Mexican government's willingness to let American troops on its soil would strengthen ties between the two nations. In his note to Seward, Romero hoped "the United States will see in the grant of this permission a fresh proof of the sincere desire which animates that of Mexico to draw closer the relations of friendship which happily exists between the two countries.”27 The way to a major Union campaign, originating in the Far West, was now open.

For Sumner, this should have been an opportunity to fulfill his desire to serve in a more active theatre of operations. Almost from the day he arrived, he lobbied for the War Department "to authorize me to place Colonel Wright here in command of the department . . . if my services should be wanted elsewhere, I could be withdrawn from

\footnotetext{
${ }^{26}$ O.R., 50, 1: 572.

27 Romero quoted in Philip W. Kennedy, "Union and Confederate Relations with Mexico," Duquesne Review 1 (1966), 48.
} 
this department without detriment to the public service.”28 Thus, Scott's orders should have been the answer to a prayer; however, he did not relish these orders any more than he did remaining in the Union’s western most headquarters. Much of the problem lay in the fact that Sumner was far more pragmatic than either the starry-eyed McClelland or Fremont, and more realistic than the overly optimistic War Department and commanding general. Although he proclaimed his full support for an endeavor that would bring him into combat with organized Confederates, deep in their own territory, the plan, he informed the high command, was fraught with flaws.

The orders reeked of desperation, and Sumner knew it. He must have been stunned when he received Scott's message. If anyone at Army Headquarters should understand the difficulties inherent in moving a large force across inhospitable northern Mexico, it was General Scott. The Mexican-American War, after all, made Winfield Scott into a national hero, yet he gave his approval to a plan so audacious as to be foolhardy.

In his August 30 reply Sumner cautioned, "I shall get the force authorized to be raised here into my hands as soon as possible; but it will take some time to do this.” Furthermore, he suggested, “Guaymas will be a much better point of departure than [the proposed] Mazatlan. ${ }^{29}$ Sumner followed up on his suggestion for a new landing site by expressing his belief that "a more feasible plan [would be] to take my command by sea to some point in Texas.”30 Such a tactic would alleviate the almost prohibitive burden of
${ }^{28}$ O.R., 50, 1: 472.
29 Ibid, 594.
30 Ibid. 
trying to carry sufficient supplies over thousands of miles of harsh deserts. In a final effort to discourage Army Headquarters from pursuing this rather rash campaign, Sumner concluded his response to the Adjutant General's office by flatly stating, "a march at the usual rate across those deserts would unevitably unfit volunteers for some time for efficient service in the field.”31

Apparently, as time passed, others began to share Sumner's concerns. Whether it was Sumner's dire assessment of the campaign's obstacles or perhaps just that far off politicians and desperate generals finally admitted the impracticality of the scheme, the plan was stopped before a single soldier boarded a ship for Mexico. Orders issued in Washington by Army Headquarters on September 9 canceling the plan finally reached Sumner nearly a month later. ${ }^{32}$ Although in April 1862, Sumner’s replacement, Brigadier General George Wright, issued orders to a subordinate that "should the forces of [Confederate Brigadier General H.H.] Sibley invade Sonora, you will pursue them without regard to boundary lines,” no Union officials ever gave serious consideration to entering western Mexico again. ${ }^{33}$

The planning and preparations, however futile they appeared at a quick glance, aided the Union cause, although not in the manner envisioned by the proponents. The concentration of regular forces stepped up to fulfill the Mexico plan quickened Sumner’s ability to carry out his new orders. The War Department’s new plan called for Sumner

${ }^{31}$ Ibid.

32 O.R., 50:1, 613.

${ }^{33}$ Ibid, 1042. Confederate Colonel James Reily's diplomatic mission to the Mexican states of Chihuahua and Sonora caused Wright's anxiety. Since Reily represented General Sibley, Wright had little reason for concern after Union troops routed Sibley's Confederates early in 1862, thus eliminating Reily's minimal air of legitimacy. Martin Hardwick Hall, "Colonel James Reily's Diplomatic Missions to Chihuahua and Sonora,” New Mexico Historical Review, 31 (1956), 239-241. 
and the bulk of the regulars to embark for New York, and the eastern theatre of the war, as soon as possible. ${ }^{34}$ Even though Sumner used the early preparations for the trek through Mexico to expedite the transfer of the regulars eastward, progress remained slow while volunteer regiments filled up.

In a rather odd twist, the failure to keep the original plan secret actually benefited the Unionists. Pro Confederates who eventually heard rumors about a planned Union landing at Guaymas passed that information onto Confederate leaders. The informants ascertained, correctly, the probable debarkation location as well as the intended destination -Texas. However, accurate intelligence is not generally useful if it is not also timely, and despite knowing the general plan, Confederate information lagged behind terribly. Even though the Union government suspended the operation in September, the plan’s spectre succeeded in distracting a plethora of western Confederate commanders for months thereafter. Their concerns never rose to frantic consternation, but in the confused atmosphere that riddled the Confederate leadership in the far Southwest, the thought of a Union landing at Guaymas, aimed at Texas, remained the bogeyman in their darkest nights. ${ }^{35}$

Union interest was not limited to what the Confederates did, or might do, below the border, nor did it end once they scrapped their own plans to use Mexico as a backdoor through which to attack Texas. Department of Pacific leaders, as well as those in

${ }^{34}$ O.R., 50, 1: 620-621.

35 O.R., 4,132-137. The Confederate commander in Arizona, Colonel John R. Baylor, expressed his fears about a Union march across Mexico to his superior, Brigadier General Henry Sibley, in both October and November. In early November Sibley, in turn, forwarded Baylor's letters, and those from other sources, to the Confederate War Department, informing the officials in Richmond, "I regard the probable advance of the Federal forces there as a movement decidedly to be desired by us, and that so soon as my force shall reach the field of action it must result in the destruction or capture of the enemy's forces.” Ibid, 132. Sibley, of course, never got the chance. 
Washington, grew increasingly concerned over international affairs in Mexico when, in late 1861, European powers seeking repayment of loans became involved in internal Mexican affairs. The external pressure applied on the Mexican government further destabilized President Benito Juarez’s precarious hold on his country. Finally, the French conquest of most of the country in 1862 and 1863 shattered the fragile stability in Mexico, greatly alarming American officials in the process.

Department of the Pacific commanders faced a complex problem when formulating a policy to deal with potential dangers posed by the warring in Mexico. Since it was national policy to remain neutral, troops on the Pacific Coast enforced neutrality on a population that openly despised the French presence, in part for its subjugation of a neighboring republic, but mostly because of the nearness of imperialistic armies to American borders. The presence of a significant number of Mexican nationals made this all the more difficult, and the intrigues of both French and Mexican agents posed an additional impediment to maintaining neutrality and stability.

The deteriorating situation in Mexico created concerns far beyond the Department of the Pacific and the recently created Department of New Mexico. Instability had long been a problem in Mexico, and it strangled the country in the years prior to the American Civil War. In 1857 Mexican officials crafted a constitution, which alienated the conservative elements, especially the elite clergy. In September of that year, Ignacio Comonfort, acting president since 1855, was duly elected to the executive post under the new constitution, with Benito Juarez accepting the second highest position. ${ }^{36}$ Almost immediately the new president became embroiled in a plot to suppress the constitution

${ }^{36}$ Charles Allen Smart, Viva Juarez!, (Westport, CT: Greenwood Press, Publishers, 1975) 130. 
and replace it with a dictatorship. The conspirators soon found President Comonfort too indecisive to lead such a usurpation, so they forced him to step down in January 1858. Comonfort's resignation elevated Juarez to the presidency, but it was too dangerous for him to remain anywhere near Mexico City, by then under conservative control. For the next three years civil war raged in Mexico. ${ }^{37}$

The fighting in Mexico not only devastated many parts of the country and left thousands dead, it kept the legal government from addressing its international responsibilities. By the time Juarez's liberals retook Mexico City in the fall of 1860, the nation's economy was in free fall. In a desperate effort to stave off a complete collapse, in July 1861 the Mexican Congress, by a vote of 112 to 4, put a moratorium on the repayment of its debts, a move Juarez hoped would give the nation a chance to rebound. ${ }^{38}$

Sensing that the moratorium might become permanent, England, France, and Spain determined to take matters into their own hands. On October 31, 1861 representatives from the three countries signed an agreement in London that committed each to the drastic step of occupying part of Mexico in order to guarantee repayment of debts owed them. ${ }^{39}$ All three nations acted quickly to carry out this international collection work. Starting on December 8, Spanish ships began arriving at the Mexican port city of Vera Cruz; a month later the English and French contingents arrived. ${ }^{40}$ The combined operation included 700 Royal Marines, 6,000 Spanish troops, and 2,500

37 Ibid, 157-168.

38 Ibid, 252.

39 Alfred Jackson Hanna and Kathryn Abbey Hanna, Napoleon III and Mexico, (Chapel Hill: University of North Carolina Press, 1971) 38-39.

40 Ibid, 40-41. 
Frenchmen. Union defeats in the early months of the war prohibited the northern government from responding forcefully to this violation of the Monroe Doctrine.

In the absence of any support from the Americans, there was little the still fractionalized Mexicans could do to oust the European forces. Although it did not help Juarez, the Spanish and English envoys soon recognized that the French had no intention of adhering to the Tripartite Treaty of London. Therefore, the European powers, which met at Orizaba, concluded they could not reconcile their differing views and dissolved the tripartite arrangement on April 9, 1862. ${ }^{41}$ With the departure of the English and Spanish forces, the French initiated a war of conquest, which forced the duly elected government, the only one the United States recognized during the crisis, to move from one place to the next in order to stay ahead of the French troops.

The dramatic increase in the number of French soldiers in Mexico, and their eventual seizure of Mexico City on June 12, 1863, alarmed many Americans. ${ }^{42}$ Americans, including civilians and military and political officials, sympathized openly with the Juarez government, which was a government more in name than in actuality. American opinion solidified against the French even further when Napoleon III had officials in Mexico lay the groundwork for the appointment of a European royal as emperor of Mexico. In the end, Austrian Prince Maximillian assumed the Mexican throne, which he held not by the grace of God, but through Napoleon III's military support.

41 Ibid, 43-44.

42 According to author William L. Shaw, there were some 46,000 French and French allied forces in Mexico by June 1865. William Lawrence Shaw, The Impact of Napoleon III Upon the Pacific Coast, (Sacramento, CA: California Civil War Centennial Commission, 1963 ), 7. 
The presence of some 40,000 French and French-allied troops roaming about Mexico, meddling in that nation's internal affairs while trying to capture its lawful president, caused a great deal of concern for the American president, Congress, and the Union commanders in the Southwest and Far West. Essentially, as the Army and Navy Journal told its military audience, "Next to the Southern Rebellion, no question is of greater interest to the Army and the entire country than this of Mexico. One main object of the intervention, as publicly avowed by its imperial author [Napoleon III], was to arrest the growth of the power of this Republic [the United States]." ${ }^{43}$ Echoing that view, U.S. Senator James McDougall warned that "It will not be long before the front of an undisguised enemy will be exhibited to the Republic; and simultaneous with that will be the attempt to seize upon all there is of our Republic on the shores of the Pacific." ${ }^{44}$ Senator McDougall also reprimanded the government for its decision to ignore the wellestablished Monroe Doctrine: "the duty is now devolved upon this Government to protest against, and if necessary, resist by force of arms the extension of the power and policies of France, with the monarchical institutions of Europe, over the neighboring republic of Mexico.» ${ }^{45}$

Despite the anger voiced by many, with the Civil War in progress, it behooved the Union government to avoid becoming entangled in another war. American response, therefore, came in two forms: individuals, both average citizens and leaders like Senator McDougall, publicly denounced both the violation of the Monroe Doctrine and its

${ }^{43}$ U.S. Army and Navy Journal, April 9, 1864, 552.

44 J.A. McDougall, French Interference in Mexico: Speech of Hon. J.A. McDougall, (Baltimore: John Murphy and Company, 1863), 5.

${ }^{45}$ Ibid, 20. 
resulting usurpation of the elected Mexican government as well as the perceived threat to American territories and states. Administration officials faced an infuriating situation where any personal desire to threaten France with the use of force had to be muted for the good of the nation. In short, the official course of action was inaction. As Secretary of State Seward put it, “in the present circumstances the United States would sacrifice Mexico if she thought it would save her from French intervention in the U.S. Civil War which hangs over her." ${ }^{46}$ Thus, despite some impotent remonstrations and toothless Congressional proclamations, the American government committed itself to a neutrality stance regarding the French presence in Mexico.

Seward understood that many Americans, including military personnel, in the affected regions might oppose this policy. In an effort to make the Federal government's position as clear as possible he gave those commanders whose responsibilities reached the Mexican borders detailed instructions. Seward informed the officers that, "You should be specially charged to do whatever is practicable, consistent with the national safety and dignity, to avoid any collision between the forces under your command and either of the belligerents in Mexico, and even guard so far as may be possible against suffering any occasion to arise for disputes or controversy."47

With a large segment of the population opposed to the government's neutrality position, enforcing such a national policy proved cumbersome in the Far West. Despite the need to focus on the ongoing Civil War, the blatant nature of the French imperial conquest of Mexico angered many in the Far West and Southwest, many of whom feared

\footnotetext{
${ }^{46}$ Hanna and Hanna, Napoleon III and Mexico, 73, quoting Seward.

${ }^{47}$ O.R., 34, 2: 595.
} 
the French more than the Confederates. The proximity of a European-supported (some said puppet) imperial regime exacerbated that anger. Ensuring that the official neutrality position remained intact fell to the senior officer in the region, the Department of the Pacific commanders -first Sumner, then Wright, and eventually McDowell.

All three generals were career soldiers, and as such they carried out their orders regardless of popular opinion. However, none of the department commanders were dispassionate about the monarchical assault on a republican government in the Americas, and the resulting dangers it posed. During their tenures as commander, both Sumner and Wright, although under somewhat different circumstances, contemplated sending American troops into Mexico. ${ }^{48}$ McDowell, who assumed command in June 1864, was no less contemptuous of the French actions. However, by the time he arrived, the French already controlled much of Mexico; therefore, any move he contemplated making below the border would almost certainly ignite a war between France and the United States. Therefore, maintaining neutrality, not surprisingly, proved difficult in this highly charged atmosphere, where a significant portion of the civilian population openly sympathized with the Mexican cause. Making matters more precarious, the military commanders, whose job it was to uphold federal policy, likewise either sympathized with the Mexican plight or worried about French designs (which some feared included a Confederate component) on America’s most distant lands.

General George Wright assumed command of the Department of the Pacific months before England and Spain pulled out of the tripartite agreement, leaving France a

${ }^{48}$ While the extent of Sumner's involvement in a planned operation in Mexico consisted of making the best of an operation in which he had little faith, Wright proposed sending troops to take the port city of Guaymas, thereby keeping it from either the French or Confederates. 
freer hand in its dealings in Mexico. Thus, for most of the war, protecting America's western borders and doing everything possible to prevent Mexicans, Frenchmen, or Americans from compromising the nation's neutrality fell to Wright. Once thousands of invading soldiers landed in Mexico, it became impossible for the French to maintain the veneer that they were there to recoup the rather questionable debts owed its citizens. Like many others, Wright bristled with indictments of French actions. He went so far as to describe the French regime as "a rapacious and unscrupulous power" which he felt "covets California and will fraternize with rebels to accomplish its end." ${ }^{49}$ Unlike others, however, his job necessitated that he harness his personal views in order to carry out national policy.

Wright's indictment of the French might have been off somewhat regarding the relationship between Confederates and the Maximillian regime, but at the time plenty of evidence, both from abroad and in the Americas, gave weight to his views. As a result of the general anxiety caused by the near proximity of French forces and the presence of Mexican agents in California, Union forces in southern California, most notably at the inhospitable Fort Yuma, kept a watchful eye southward. In essence, even after the Confederate threat along the southeastern most section of the state receded, the possibility of a French incursion necessitated vigilance.

Despite the anger toward, and resulting attention given to, the French military, the more immediate threat to American neutrality in the Far West came from the Mexican and French agents, whose intriguing in California and Nevada could at any time incite Americans to join in the fighting. In California, especially from San Francisco

${ }^{49}$ O.R., 50, 2: 792 
southward, something akin to an espionage war took place between operatives from both factions.

San Francisco served as the epicenter of this cold war, where both France and republican Mexico maintained consulates. The Mexicans struggled on three fronts, hoping to induce American citizens to put pressure on the federal government to terminate the detrimental neutrality policy, while simultaneously, and covertly, buying much-needed arms and munitions and trying to raise mercenary forces to come to their aid. At the same time the French officials focused their efforts on ensuring that American officials, meaning the military and local magistrates, enforced the unpopular neutrality policy. Department of the Pacific commanders found that maintaining equilibrium between national interests and sympathy for the neighboring republic was increasingly difficult in such an atmosphere.

No single individual made maintaining American neutrality in the Far West more difficult than Placido Vega, former governor of the state of Sinaloa and a Juarist general after $1860 .^{50}$ As the situation grew bleaker for the Juarez government in 1863, the president and his advisors decided to take a drastic step. In desperate need of arms, munitions, and men, President Juarez sent Vega on a not so secret mission to San Francisco, to purchase war materials, and, if possible, raise forces for the Mexican cause. Although Vega himself did not arrive in San Francisco until 1864, his aides reached the city in October 1863. Over the next three years the general and his aides spent over half

50 For Vega's role in gathering supplies and promoting the Mexican cause in California see, Robert Ryal Miller, “Arms Across the Border: United States Aid to Juarez During the French Intervention in Mexico,” Transactions of the American Philosophical Society, 63 (1973) 6, 16-30. 
a million dollars buying weapons, munitions, raising troops, and greasing both the press and the political machine in California and, to a far lesser degree, in Nevada. ${ }^{51}$

Despite the Department of the Pacific's efforts to enforce neutrality by stopping shipments of military goods believed destined for Mexico and hindering the travel of persons suspected of trying to join the Mexican cause, westerners openly supported Vega's efforts. Acquiring arms proved easy in such an atmosphere. The first shipment of any size reached Mazatlan in December $1863 .^{52}$ Two months later, over a thousand rifles and ammunition reached Juarist troops; and the trade continued until December 1866. ${ }^{53}$ The gamble, at least in regard to acquiring arms, appeared to pay off.

Finding someone willing to sell arms proved easy; however, getting those arms to Mexican forces proved more difficult. Although more shipments arrived in Mexico than were stopped by American officials, both civilian and military, the process was fraught with uncertainty and inconsistency. The difficulties Vega and his subordinates faced were not accidental, but rather part of the concerted effort by French agents to thwart every step the Mexican officials made. Just as Vega and others acted with the knowledge and approval of the Mexican consulate in San Francisco, French officials in their consulate worked to counteract the Mexican moves. The most effective French official in the hunt to expose any activity violating the American neutrality policy was the

${ }^{51}$ Robert Ryal Miller, “Californians Against the Emporer,” California Historical Society Quarterly, 37 (1958), 193.

52 This shipment included 143 Colt pistols and over a million percussion firing caps. Miller, “Arms Across the Border,” 18.

53 Ibid, 21. 
consul himself, Charles Ferdinand Cazotte, who replaced the outgoing consul in January $18644^{54}$

The French held an important advantage over the Juarists in this peculiar struggle. The United States' official neutrality stance enabled the French to cajole unsympathetic civilian agents and Department of the Pacific officials into thwarting Mexican efforts to acquire goods and men. McDowell illustrated the awkwardness of this situation when he wrote Vega in late 1864 that despite "the interest \& sympathy which in common with the majority of my countrymen I feel for your country,” national policy superseded both popular and personal sentiments. ${ }^{55}$ Since the Mexican agents' continued efforts to raise arms and material placed Department of the Pacific officials in the undesirable position of enforcing those policies, McDowell rather curtly pointed out to Vega, "I am in no way empowered by the Government to regulate its foreign policy, and am in no position to discuss it with you. That if you find any cause of complaint in the conduct pursued by any one in this matter, your proper course is to lay it before your minister in Washington."56 The message was clear, American officials would confiscate any weapons and materials destined for military use by the Juarists and they would impound any vessels carrying those items.

French consul Cazotte, who understood that Americans in the region, and elsewhere, loathed both the French incursion in Mexico and the near proximity of thousands of imperial troops, relied heavily on the officials’ reluctance to abrogate

\footnotetext{
${ }^{54}$ A. P. Nasatir, “The French Attitude in California During the Civil War Decade,” California Historical Society Quarterly, 43 (1964) 1, 28.

55 O.R., 50, 2: 1075.

56 Ibid.
} 
standing orders. Of course, Cazotte and the others understood enforcing the law and seeking out violators and their cargo were not the same. Since neither was carried out with any élan, both required incentives. After sizing up the situation, Cazotte informed the French Foreign Office in Paris that

In this country everything has its price, and if the armaments continue, as a result of the present situation in Mexico, I will be able to stop them only by means of 'gratifications' at the right moment to certain officials, and especially the chief of police, who seems devoted to us. I dare, then, to propose to Your Excellence, that if Chief Burke should continue to make important seizures of arms and of contraband of war, to be so good as to put at my disposition funds for unforeseen events. $^{57}$

Furthermore, Cazotte bluntly informed his superiors that "I do not believe those whom I employ in these affairs will be very happy with pretty words." ${ }^{58}$ Officials in Paris heeded their consul's deft characterization of the situation in San Francisco and established a line of credit for Cazotte's use in bribing willing American officials.

Wise distribution of these funds enabled agents to obtain information about Mexican efforts to purchase arms and supplies. Cazotte, in turn, passed this information on to the local magistrate and customs officials, whose job it was to assist in enforcing the neutrality law by preventing either belligerent from acquiring military supplies. ${ }^{59}$ The chief of San Francisco’s police force, M.L. Burke, who supplemented his income

${ }^{57}$ Cozotte quoted in Lynn M. Case and Warren F. Spencer, The United States and France: Civil War Diplomacy, (Philadelphia: University of Pennsylvania Press, 1970), 523.

${ }^{58}$ Ibid.

59 Although the laws applied to both the French and the Juarez regime, the French rarely sought any supplies or assistance that violated the spirit of American neutrality, whereas the Juarists hoped to acquire significant amounts of material in California. In a few instances, however, French warships ventured into San Francisco, and were allowed to go about their business with little interference (in one case the ships resupplied and in another, storm-damaged French warships were repaired there in 1864. Both occasions led to outraged cries of duplicity from General Vega and the Juarist representative in Washington D.C. Despite the accuracy of Vega's protest, American officials, both civilian and military, assented to the French requests. 
with French bribes, readily acted upon the information supplied him. Chief Burke was not the only important San Francisco official wallowing in the French trough. Many believed the city's chief collector of customs, Charles James, was also on the French payroll. State surveyor general, Edward Beale, denounced James in a letter stating, "You are known to have had frequent and cordial interviews with the consul of France, and you will be seen by the thoughtless multitude through a flood of French gold, which will be believed to have overwhelmed your integrity."60 Whether or not James accepted French bribes is not entirely clear, but there is no denying he zealously worked to prevent any military material from reaching Mexico. His effort was so strident that Beale promised "your name will become the synonym of everything that is humanly base wherever the Democracy rears the flag of a free people.”61

The combination of Burke and James proved valuable to the French, and troubling for Vega. In April 1864 officials seized 3,000 rifles aboard the American ship John L. Stephens. Later that summer, a revenue ship seized an American merchant vessel, the Haze, while agents in San Francisco took possession of rifles, ammunition, and cannons waiting to be shipped. The haul amounted to approximately 9,000 rifles and more than a dozen cannons. ${ }^{62}$ Despite these successes and the continued assistance of the chief of police and the zealous head customs officer, Cazotte only succeeded in disrupting, but not stopping, the flow of arms from California to the Juarists in Mexico.

\footnotetext{
${ }^{60}$ Beale cited in Miller, Arms Across the Border, 19.

${ }^{61}$ Ibid.

62 Ibid, 21.
} 
Far more important to maintaining neutrality, and thereby keeping the United States out of the fighting in Mexico, was preventing Americans from joining the fray below the border. Where civilian officials held the primary responsibility for intercepting any shipment of arms and supplies destined for the Juarists, prohibiting the raising, organizing, and eventual movement of an American expeditionary force to Mexico fell predominantly to the United States military. Failure to prevent Americans from assisting President Juarez in his struggle might induce French forces to take military action possibly on the American side of the border. The Lincoln administration fully understood that any confrontation between American citizens or, worse, military personnel, would ignite a war, and as Grant said in 1864, "we want Napoleon out of Mexico, but we don't want any war over it; we have certainly had enough war.”63 As General Vega discovered, many people shared half of Grant's opinion. From the outset of his mission, Vega had been candid about his desire to acquire arms and munitions in California. He went so far as to point out to Department of the Pacific commander McDowell that in an April 1864 meeting he gave California Governor F.F. Low and Edward F. Beale, then with the Army Corps of Engineers, "full details [of] the object of my mission, which amounted substantially to procuring the means necessary for repelling the usurpation of Maximilian in Mexico." ${ }^{, 4}$ However, he understood that attempting to acquire arms and supplies, which in itself violated America's neutrality, was one thing and openly raising troops in defiance of that neutrality was another.

\footnotetext{
${ }^{63}$ Quoted in Porter, 256.

${ }^{64}$ O.R., 50, 2: 1038.
} 
Therefore, in order to raise troops to help expel Maximilian and his French masters from Mexico, Vega acted more covertly.

President Juarez needed Vega to recruit the largest force possible in California. However, concentrating and transporting any sizeable body of men almost guaranteed detection. An additional problem stemmed from the need to advertise. Vega needed to get the word out, but doing so had to be done without raising suspicions; otherwise, military and civilian officials might imprison anyone caught recruiting by invoking Department of the Pacific, General Order Number 5. The order prohibited citizens from sailing to Mexico without convincing officials they had no intention of aiding either side in any manner. ${ }^{65}$ The Mexican agents needed to use ingenuity to evade these dual problems. Vega proved more than capable of using deception to maintain as much secrecy as possible.

Shortly after the French initiated large scale operations in 1862, angry native Californians organized "Mexican Clubs," where increasing numbers of citizens vented their rage while discussing what they might do to aid their brethren in Mexico. ${ }^{66}$ Juarez's agents took full advantage of the presence of those organizations by seeking aid from its members, and in fact, the Juarist operatives contributed funds to encourage their continued existence. Vega used the clubs, as well as the Spanish language newspapers, to get the word out regarding an effort to create a new "colony" in northwest Mexico. He named the first effort to raise men the Arizona Exploring Expedition. Any such

${ }^{65}$ Ibid, 1133. The order also stated "No person will be received on board of any vessel at this port for any port in Mexico without his having previously registered his name at the office of the provostmarshal and received a permit to embark."

${ }^{66}$ At that time the term "native Californian” referred to the Hispanic population born in California prior to its annexation to the United States in 1848. 
colonizing endeavor required dealing with the frequently hostile Apache Indians, which rather conveniently enabled the body to circumvent American laws prohibiting the emigration of well armed groups.

With Mexican agents able to both advertise for troops and explain the transportation of heavily armed bodies, it only remained to be seen if Americans would respond. If there had been any doubt about the likelihood of raising troops in the Far West, the continuous flow of letters of inquiry made it clear that Americans were willing to take up arms for Mexico. Edward Lever spoke for many prospective volunteers when in November 1864, he wrote Vega, "Being in heart and soul a believer in republicanism, I have long sympathized with Mexico and her patriots, therefore I offer myself for any position whereby I might be of service." ${ }^{, 7}$ One of the volunteers, A. A. C. Williams, forwarded testimonials about his martial service from a number of Union generals to Vega, who after meeting him appointed Williams a colonel in the Mexican national guard. ${ }^{68}$ As expected, the native Californians also readily volunteered to help liberate their former country from the imperial yoke. In fact, Vega found generating interest easy among the Hispanic population, republicans, mercenaries, and disappointed miners throughout California and Nevada, where he focused his efforts.

Generating interest and organizing bodies of men proved easier than getting them past Union officials in the Far West, who suspected the Arizona Exploring Expedition's objective. However, so long as the group's existence was not overt and it did not attempt to leave for Mexico, officials let the charade continue. The fact was that until they set out

\footnotetext{
${ }^{67}$ Lever cited in Miller, Arms Across the Border, 23.

${ }^{68}$ Ibid, 26. Williams eventually rose to the rank of general.
} 
for Mexico they maintained the façade of not violating the neutrality law. However, Department of the Pacific officials fully understood that Vega's effort to raise men went against their primary objective of maintaining stability in the Far West. Despite their personal sympathies for the Mexicans and hatred of the French, the department commanders' responsibility was to ensure the stability of the Far West. In this case, that meant prohibiting the raising of men to aid Juarez.

General Wright, demoted to District of California commander in late summer 1864, stated the position unequivocally, "our neutrality must and shall be preserved in good faith. No recruiting rendezvous for enlisting men for foreign service will be allowed at any place in the State. No bodies of armed men will be permitted to sail from San Francisco or any other point on the coast. Any violation of this regulation after due warning will be met by the prompt arrest of the offenders." ${ }^{\text {69 }}$ Previous experience in smuggling arms and supplies out of California, even if the success rate teetered around fifty percent, gave Vega reason to hope for success in raising and sending men to Juarez. In any case, given the desperate situation in Mexico, Vega and the other agents had no choice but to test the officials' commitment.

In May 1865, with the Civil War virtually over, Vega finally arranged to transport a body of 400 men to join the Juarist forces in Mexico. ${ }^{70}$ Despite the fact that American policy regarding the shipment of arms (and men) to Mexico was in flux, and murky, at the time, officials in San Francisco prevented the Arizona Expedition from sailing and, as

\footnotetext{
69 O.R., 1233.

70 Miller, Arms Across the Border, 27.
} 
Wright warned, jailed some of those involved. ${ }^{71}$ Although American policy soon became more helpful for republican Mexico, the setback proved significant. Through the joint work carried out mostly by civilian and treasury officials (some of whom were aided by French spies), with the support of the military, no organized bodies of volunteers left for Mexico until 1866, by which time the United States government relaxed laws prohibiting aid to the Juarez government.

Department of the Pacific commanders and men, with the significant assistance of government officials, prevented any dangers emanating out of Mexico from drawing Americans, and eventually the nation, into the morass below the border. During the course of the Civil War, Department of the Pacific leaders maintained the sanctity of their department and the safety of the people from being imperiled by dangers bubbling in Mexico. American neutrality had been preserved, and Mexico, as Secretary of State Seward predicted, nearly sacrificed to the Europeans in the process.

During the Civil War, Union troops patrolling the southern part of the state, along with fellow California volunteers serving in the Department of New Mexico, protected the Far West and Southwest from a myriad of dangers along the regions' southern borders. By distributing troops to confront potential threats, including sending a large contingent from the Department of the Pacific into New Mexico Territory, department commanders upheld their primary objective of maintaining the integrity of the region for the federal government.

By marshalling their troops effectively, Department of the Pacific officials deterred both the French and the Mexicans from either advancing, as in the former case,

71 Ibid, 27 and 28. 
or retreating in the latter, into America. The work to protect the Far West, and thereby the nation, from being sucked into the Mexican vortex was complicated and required vigilance by the officers and men stationed in the southern part of the department, deft political maneuvering by its commanders, and stealth by civilian and department personnel thwarting violations of neutrality. By maintaining the integrity of the borders and the nation's neutrality in the face of public support for the Mexican cause, and despite their own sympathies, Department of the Pacific officers and men achieved an important and complicated success for the Union.

Keeping the Confederates from establishing a southwestern/far western empire, proved no less important for the Department of the Pacific than making certain the imperial war stayed in Mexico and that Americans did not join either side. Although Union forces under the overall command of Colonel E. R. S. Canby delivered the fatal blow to the Confederate Army of New Mexico in March 1862, Department of the Pacific forces played a key role in arresting Confederate designs on New Mexico Territory and beyond. Advance elements of District of Southern California commander James Carleton's command turned back a Confederate probe less than 100 miles from California. Just as department commander Wright sent Carleton and his California Column eastward to block any Confederate advance, he also shifted troops to southern California and strengthened their most exposed post, Fort Yuma, all in an effort to thwart any Confederate designs on California. The successful combination of Wright's marshalling of troops, Carleton's vigorous recapture and occupation of New Mexico Territory, along with Confederate defeats in the eastern part of the territory nearly eliminated any further serious southern threat to the region. 
Even the aborted Union march across Mexico benefited the nation. Although General Sumner did not lead a large contingent of troops across northern Mexico, the plan expedited the concentration and departure of the Regular Army forces for the eastern theatre. Similarly, the rumors about the Union advance kept wary western Confederate leaders on edge well after the Federal War Department scrapped the plan. In effect, the aborted mission served the Union cause by expediting the transfer of the U.S. Regulars eastward and by forcing western Confederates to expend energy and time preparing to counter an invasion that never came.

Whether it was the almost accidental benefits gained by the rumored Union march across Mexico, the role in repelling Confederate attempts to establish a southwestern empire, or the deft handling of the dangers posed by the imperial war in Mexico, the Department of the Pacific successfully confronted these threats to the stability of the Far West. By effectively dealing with these dangers, the officers and men in the department achieved all that the Union government asked of them. In a unique, although undeniable, way the Department of the Pacific's ability to neutralize all external dangers along both sides of the Mexican border, and thereby prevent the loss of the Southwest and California, or requiring the transfer of large numbers of Union troops to the region, contributed to the successful war effort. 


\section{CHAPTER}

$-6-$

\section{An Old Problem in a New War: The Department of the Pacific and White-Native American Relations During the Civil War}

In November 1863 a rather exasperated General George Wright dictated a note from his San Francisco headquarters. In it he curtly reminded one of the seemingly endless streams of local officials besieging him with frantic pleas for assistance and protection that each of their local concerns was part of a larger myriad of responsibilities he faced. Wright informed the frightened officials that department responsibilities superseded individual regional problems, stating: "You must bear in mind gentlemen, that I have a great many urgent calls for troops to protect our hardy pioneers against Indians, and a very small number of soldiers to meet all these pressing calls ... I have still more important business on hand to look after traitors within our borders, and to be prepared to meet foes from without."1

The terse tone of Wright's reply easily misled some civilians about his level of both understanding and concern over the precarious and often volatile relations between whites and Native Americans. Wright, who spent the last 13 years of his 43-year military career on the Pacific Coast, understood the difficulties of trying to maintain peace better than anyone. Unfortunately for worried westerners and their harried civilian leaders, the Civil War and its myriad of new problems and responsibilities prohibited western

${ }^{1}$ Official Records of the War of the Rebellion, (Washington: Government Printing Office, 1897), 50: 2, 663. 
military officials from focusing their attention solely on relations with the tribesmen. For the Department of the Pacific, the war dramatically complicated an old problem, which grew worse with each new wagon train rumbling across the prairies and every ship load of passengers arriving in San Francisco. Balancing the demands of whites with the desire to avoid open conflict with the too frequently abused Native Americans required delicate handling of the complicated situation, and the failure to do so resulted in a number of conflicts. Although citizens in every part of the department believed they were in grave danger, the most volatile, and complicated to administer, regions were in coastal northern California and along the immigrant trails. In these places, and throughout the department's jurisdiction, Wright and the other commanders struggled to find solutions, employing political maneuvering, intimidation, and the use of force to protect whites. In this increasingly difficult environment, the Department of the Pacific leaders faced a continuation of the bloody 1850s.

The problems that complicated, and frequently foiled, efforts at maintaining some sort of peaceful existence between the various far western tribes and the Department of the Pacific was merely a stage in the decades-long struggle between white Americans and indigenous peoples in the region. From the start, finding an effective means to ensure calm between whites and Native Americans in the Far West required both luck and understanding, on both sides. One or both elements seemed lacking throughout the 1850s, as war raged between Native Americans and whites for most of the decade. The 1850s, in fact, served as a bloody foreshadowing of what the western plains witnessed in the 1870s and 1880s, ultimately culminating in the massacre along Wounded Knee creek in South Dakota in 1890. Although a brief calm reigned in the Far West in 1861, it did 
not last, and department commanders, especially George Wright, found themselves desperately trying to cope with an old problem.

The problem was not that the government initiated new policies or followed new strategies when dealing with the tribes during the war. What gave rise to a new wave of violence was the increasing numbers of whites migrating to the Far West during the war, and the subsequent increase in the abuse of the Indian population, combined with the effect of the multifarious responsibilities facing the military. In fact, the policies followed during the 1860s were a continuation of the same policies carried out by men like George Wright during the previous decade. ${ }^{2}$

Of course, the most dramatic increase in population in the Far West exploded in California beginning in 1849, after the news of the discovery of gold reached the populated regions of the country in the East. The resulting human flood devoured California's Native American population over the next ten years. The influx of miners brought death in several ways: diseases, which by the time of the American acquisition had already dramatically reduced the indigenous population, whittled away at the remaining 100,000 Native Americans; violence toward the tribes by gold seekers spilling onto their lands and further reduced their numbers; and, finally, miners swarming over Indian lands made it difficult for the Native Americans to obtain sustenance. The massive crush of whites in such a short span of time only expedited the inevitable. Unlike the larger, well organized and loosely connected tribes associated with the Great Plains, Southwest, and to a lesser degree, Pacific Northwest, tribes in California were

${ }^{2}$ Wright's activities against the Yakimas and Spokanes (among others) in the 1850s will be described later in this chapter, but it is important to recognize that he had the most field experience against the tribes of any senior officers that served in the Department of the Pacific during the Civil War. 
smaller, family-based, less organized, and were unlikely to create alliances with neighboring tribes. These tendencies made it easier to subdue and dispossess the rapidly declining population of Native Americans throughout the 1850s.

Given the rapidly changing population dynamics in California, there were very few confrontations between the indigenous peoples and Americans (among others) that could be classified as wars. This, however, does not mean American military officials did not face a complicated task when dealing with the two groups. Department of the Pacific personnel inherited a well-established pattern of white abuses of the tribes, which sometimes precipitated a violent response, which then gave credence to efforts to exterminate the Indians. The effect of this pattern, which was no accident, plagued military officials during the 1850s and created a mindset among civilians that haunted department officials during the Civil War.

As Wright well knew, relations between many tribes in the Far West and the Americans had been poor (at best) since the United States first organized its western lands into territories in the wake of the Mexican-American War. In fact, the first of the loosely-termed Indian wars to involve Americans ignited before Oregon’s organization as a territory or California’s official acquired from Mexico. In 1847, in what became an alltoo-common scenario, a group of Cayuse Indians retaliated against American incursions into their lands by attacking the nearest settlement, with the local American population responding in kind. ${ }^{3}$ Unfortunately, the Americans in question were a small group of missionaries who were more interested in the Cayuses’ souls than lands.

3 It is important to understand that the violence was targeted at Americans, and not just whites in general, for the British, who still had fur trading posts in the region, maintained generally good relations with most of the regional tribes. 
Marcus Whitman and his wife, Narcissa, saw their relations with the Cayuse deteriorate over the eleven years that they ran their mission (near the present city of Walla Walla, Washington). During those years the Whitmans failed miserably as missionaries, and faired only slightly better in their efforts to persuade Americans to migrate to the region. Many immigrants who headed for the Willamette Valley, however, were thankful to regroup for days or more at the mission before pushing further into the Oregon country. Thus, the Whitman mission served as something of an immigrant gauge, enabling anyone paying attention to grasp a rough estimate of the increasing numbers of Americans trickling (at this point) into this still disputed territory. The Cayuses took notice of the influx in immigrants passing through their lands and the resulting increase in confrontations with those groups that resulted. Frustrated by the steady, if light, stream of Americans into their country and increasingly unhappy with the presence of the Whitman mission, which was blamed for the diseases that swept the tribes, a group of Cayuses attacked the small enclave on November 29, 1847. They tomahawked Marcus Whitman to death and murdered 13 other whites before the killings came to a halt. ${ }^{4}$

In an effort to seek justice, revenge, or some combination of the two, local Americans initiated what became known as the Cayuse Indian War in early 1848. Although the resulting actions never rose to the level associated with other Indian wars, what transpired foreshadowed the conflicts that plagued the region for the ensuing ten years. Since the United States government was not yet in position to assist those far off

4 Robert H. Ruby and John A. Brown, The Cayuse Indians: Imperial Tribesmen of Old Oregon, (Norman, OK: University of Oklahoma Press, 1981), 110. 
Americans in their effort to seek justice, the local citizens took matters into their own hands. Ultimately the pursuit of the murderers proved more frustrating than fruitful; however, it did demonstrate certain tendencies that were common to all the conflicts that followed up through 1858.

Sending a mixed message, Oregon settlers organized roughly 500 armed men to pursue the Cayuses and bring those responsible to justice, while at the same time, the provisional governor, Abernethy, sent three commissioners to meet with the tribe to establish a peaceful resolution. Initially, Cornelius Gilliam’s determination to exact revenge on the Cayuses foiled the peace commissioners. As too often occurred, Gilliam and the volunteer military force he led were unable to capture those they believed responsible for the murders. Unable to sate their need for revenge, the volunteers skirmished with both guilty and innocent Indians indiscriminately during their fruitless pursuit, and even stole large herds of livestock from the tribal bands they encountered. Those encounters, which continued for months, resulted in a number of Indian deaths and increased enmity between Americans and the regional tribes. ${ }^{5}$ Finally, with the encouragement of some Nez Perce chiefs, Cayuse leaders turned over five men believed responsible for the murders. ${ }^{6}$ Following a trial in Oregon City, Oregon Territory, all five were hung on June 3, 1850. ${ }^{7}$ The end of the Cayuse War, however, did not end the sporadic violence between Americans and the tribe. Occasional raids and minor

${ }^{5}$ Reviews of the campaign can be found in Ibid, 128-141 and Francis Fuller Victor, The Early Indian Wars of Oregon, (Salem, OR: Frank C. Baker, State Printer, 1894), 152-226.

6 The Nez Perce assistance proved to be the only successful means to seeing the murderers brought before a white court. Not only had the military expedition failed to capture anyone, a sizeable reward of several hundred dollars was offered by the last commander of the volunteer unit, Colonel Henry Lee, also failed to lead to the capture of anyone. Victor, 212.

${ }^{7}$ For details of the seemingly predetermined trial, see Ruby and Brown, 163-171. 
skirmishes sputtered on until the few remaining tribal members were forced onto a reservation in 1855 .

The larger scale violence between Americans and the various tribes in the Pacific Northwest initiated by the Whitman Massacre, continued until 1858. During that time, wars erupted between Americans and tribes throughout Oregon, and later, Washington territories. The tribes that found themselves involved in those wars included Cayuse, Coeur d'Alene, Palouse, Spokan, Umatilla, Walla Walla, Wenatchee, and Yakima in north central and northeastern Oregon and south central and southeastern Washington territories. From west-central Oregon to the border with California, wars were fought against the Rogue River and Shasta tribes. Although lesser in scale, violence also broke in the Puget Sound region during this same ten year stretch.

Ultimately the military, often joined by volunteers whose wanton violence toward all Indians exacerbated growing distrust of Americans, defeated the tribes. In the wake of those defeats, the Native Americans ceded tens of thousands of acres of lands to the United States and many were forced on to reservations. Victory had not come easy, however, and the military suffered a number of defeats along the way. The most famous of those was the routing of two companies of over 100 men from the Fourth Infantry commanded by Brevet Major Granville Haller in early October 1855, at the outset of the Yakima War. A similar defeat befell Brevet Major Edward Steptoe’s command in southeast Washington Territory in late May 1858, which initiated the Plateau Indian War of that year. ${ }^{8}$

${ }^{8}$ For Haller's defeat, see Clifford E. Trafzer and Robert Scheuerman, Renegade Tribe: The Palouse Indians and the Invasion of the Inland Pacific Northwest, (Pullman, WA: Washington State University Press, 1986), 63-64, and Robert Utley, Frontiersmen in Blue: The United States Army and the Indian, 1848-1865, (New York: MacMillan Publishing Company, 1967), 188. For the Steptoe defeat, 
These wars significantly influenced the nature of relations between Pacific Northwest tribes and the Department of the Pacific personnel during the Civil War. Many officers who played prominent roles in the main theatres of the war honed their skills during the Northwest Indian wars, and two of the most important leaders who served in the Far West during the war participated in the decade-long wars. Among those who fought in the Pacific Northwest were a number of future Confederate generals, including Hylan Lyon, William Loring, George Pickett, Gabriel Rains, Richard Garnett, William Pender, and Charles Winder. ${ }^{9}$ The list of those that served the Union as generals is far longer, and includes future major generals Phil Kearney, Erasmus Keyes, John Reynolds, Phil Sheridan, and A.J. Smith, as well as a number of future brigadier generals. ${ }^{10}$ Although all these men played prominent roles in the main arenas of operation during the Civil War, two others remained on the West Coast and thereby became key leaders in the Department of the Pacific. The two officers who missed their chance for greater fame were Benjamin Alvord, who commanded the District of Oregon during most of the war, and George Wright, the man who spent more time as department commander than all others combined. ${ }^{11}$

Trafzer and Scheurman, Renegade Tribe, 77-83, and Garrett Hunt, Indian Wars of the Inland Empire, (Spokane, WA: Spokane Community College Press, n.d.) - the entire volume is a study of the1858 Steptoe-Wright campaign.

${ }^{9}$ Biographical sketches of each can be found in Ezra J. Warner, Generals in Gray (Baton Rouge, LA: Louisiana State University Press, 1959). The last three generals, including William Pender, died while serving the Confederacy. Pender, along with William Loring and George Pickett, attained the rank of major general.

${ }^{10}$ Biographical sketches of these Union generals can be found in Warner's companion volume, Generals in Blue, (Baton Rouge, Louisiana State University Press, 1964). Both John Reynolds and Phil Kearney died while serving the Union.

11 Sketches of both Alvord and Wright can be found in Warner, Generals in Blue, and for a full biography of Wright, see Carl Schlicke, General George Wright: Guardian of the Pacific Coast, (Norman, OK: University of Oklahoma Press, 1988). 
While staying in the Far West during the war significantly diminished opportunities for dramatic advancement for professional soldiers, the region was fortunate that a few, such as Alvord and Wright, remained in the area. The calm that prevailed in the region in 1860, combined with the secession of South Carolina and the Deep South, led eastern officials to forget about, or ignore, the potential problems simmering in the region. Although the first department commander, Albert S. Johnston, was an experienced Indian fighter and military man, his awareness of the situation in the Far West had limits. During his brief tenure he too endured a barrage of requests for military assistance from frightened, and opportunistic, civilians from throughout the department.

From the very beginning, after assuming command of the department on January 15, 1861, the new head of the reconfigured Department of the Pacific, found himself besieged by civilians pleading for relief from the Native Americans. For Johnston, those calls for help usually took one of two forms. Most often civilian leaders emphasized the dangers they faced if certain forts were closed as part of the reshuffling of the department's forces, or the local politicians bemoaned depredations already being carried out by local tribes. Although Johnston did not remain at his post long enough to acculturate himself to the nuances associated with dealing with the Pacific Coast tribes, he was an experienced Indian fighter who had dealt with frightened civilians before. In an effort to mollify one such a group living in the northern part of Puget Sound, Johnston assured the petitioners, “an outbreak of the Indians in those districts is not apprehended, but as the inhabitants, and the assembly thinks, feel insecure, and the presence of a military force will no doubt reassure, I will, as soon as practicable, send a small force to 
that place.”12 This was a potentially hazardous precedent. Puget Sound politicians were hardly the only civilians trying to cajole the military to take action, both defensive and offensive as the situation dictated, to prevent the various tribes from endangering the white population. Despite the fact that such fears were often more imagined than real, civilians demanded action form the already harried military.

During the approximately four months Albert Sidney Johnston commanded the Department of the Pacific he accumulated a substantial array of calls for help from civilians from as far afield as Puget Sound, along both sides of the Columbia River, the Humboldt region of northern California, and on down to southern California, near Fort Tejon. In the process, civilian leaders of varying importance from throughout the department badgered or begged for aid. All the while, Johnston faced the reality that he did not have a large enough force to appease every nervous citizen. California Governor Downey went so far as to upbraid Johnston by reminding him, "I have heretofore had occasion to make representations to the late General Clarke of depredations committed upon the property of citizens of California by hostile Indians, and it affords me pleasure to state that prompt measures were taken." ${ }^{13}$ In a justifiably irritated response to such an overt challenge to his leadership, Johnston honestly and curtly reminded the governor that he had dispatched several additional companies to the region to join those already stationed in the area. Furthermore, "at this time there is no other force available, without
${ }^{12}$ O.R., 449.
13 Ibid, 452. 
withdrawing it from positions whose security at present would seem to demand its presence." ${ }^{14}$

Despite his brusque explanation to the governor, and the views of his own officers, Johnston found it more expedient to spread his forces even thinner. In the view of one subordinate stationed in the Humboldt district of northern California, "I would hesitate to commence hostilities." His caution derived from the fact that "the white inhabitants of this section are more than anxious to be at war with these Indians. For this reason the Indians are afraid to go into the valleys for roots and berries, so that I cannot imagine how they live, and must think they merit some consideration for not stealing."15 The situation was the same in Washington Territory, where the commander of Fort Walla Walla, informed his superiors that "a large number of California miners are expected this spring. Trouble will be the result unless something is done to purchase the mineral land immediately from the Indians. They are very much dissatisfied, and their only confidence now is in the troops." 16

The ironic twist was that the military was, in many cases, the best hope the tribes had for protection. Through manipulation and less than truthful characterizations of who was responsible for the violence, civilians got military leaders to combat the Indians, and in a number of cases significant numbers joined the soldiers in their efforts. In no place was this more evident than in the northwestern counties of California. When Johnston acquiesced in the Humboldt district he agreed to allow the raising of volunteers from the
${ }^{14}$ Ibid, 453.
${ }^{15}$ O.R., 451.
${ }^{16}$ Ibid, 447. 
local population, the people most likely to benefit from the death or removal of all the local tribes. Worn down by the continual harping of civilians to form such units, and with his own manpower stretched to the limit, Johnston explained that "for the purpose of giving the most effect to their operations I have thought it expedient and proper to ask Governor Downey to authorize the enrollment of thirty volunteers ... acquainted with that mountainous country, and who I think can be attached to the different detachments as guides." ${ }^{17}$ Eventually, the employment of those guides demonstrated that the locals were more adapt not only at finding, but also at combating the raiding tribesmen.

Almost from the outset, the Department of the Pacific leaders demonstrated a lack of preparedness for dealing with the increasing problems in the Humboldt region. As the random violence escalated into warfare, it became evident that there were not enough troops in the region, and those that were sent to quell the unrest possessed insufficient knowledge of the terrain and the tribes to be effective in their efforts to "chastise" the Native Americas, as Edwin Sumner put it. Furthermore, trying to marshal the troops needed for such a task from department headquarters in San Francisco had long proven ineffective. Therefore, the first significant step in addressing the problems which plagued the region for three years occurred on December 12, 1861. On that date, General George Wright, the department's latest commander, issued Special Order 233, which created the Humboldt District. Colonel Francis J. Lippitt, commander of the Second California Infantry Regiment, assumed command of the new district, which included Del Norte,

17 Ibid, 457. 
Humboldt, Klamath, Mendocino, Napa, Sonoma, and Trinity counties, on January 12, $1862 .^{18}$

Shortly after arriving and conferring with officers already in the region, Lippitt provided Wright with an interesting assessment of the situation. He made it clear that the local whites were as much to blame for the bitterness that had led to warfare, noting "there are many whites that are constantly killing Indians, often making up parties for that purpose." Those groups, he told Wright, "Kill as many of the women and children, perhaps, as bucks [men]. Individuals and parties are, moreover, constantly engaged in kidnapping Indian children . . . This is said to be very lucrative business." ${ }^{19}$ While all that was true, Lippitt's tone of equal blame did not go over well with the locals, nor did his defeatist attitude:

These Indians are not divided into any considerable tribes with responsible chiefs, but are made up of numberless rancherias or villages, in many cases speaking totally different languages. There are so many of them, they are so scattered about, and so hard to find, that to bring them all in by sending from time to time small parties or independent detachments after them, it would take about as long as it would to bring in all the coyotes or squirrels. ${ }^{20}$

Continuing in his honest, and accurate, assessment, the colonel told Wright that it was "plain they [whites and Native Americans] could never live together in peace. The Indians must all be removed for their own sakes and for the sake of the whites, and the sooner they are removed the better.” Most importantly, to be successful, the tribes must

${ }^{18}$ Lippitt's command consisted of infantrymen from his own Second California, elements of the Third California Infantry Regiment, and cavalrymen from the Second California Cavalry Regiment. Later, local militia was formed into what became known as the Mountaineer Battalion. O.R., 50:1, 803; Richard Orton (compiler), Records of California Men in the War of the Rebellion, 1861-1867, (Sacramento, CA: State Office, 1890), 11, 826-831.

19 O.R. 50: 1, 803.

${ }^{20}$ Ibid. 
be moved far from their home region, otherwise they would leave the reservation as soon as an opportunity arose. ${ }^{21}$ All of Lippitt's observations were more or less true, and his assessment of the impossibility of dealing with the tribes according to strategies then in place proved prophetic over the next three years. ${ }^{22}$

\section{Given Lippitt’s initial assessment, Wright wanted him to conduct a}

reconnaissance of his new command as soon as was practical, and to determine the manpower needed to achieve and maintain peace in the region. What the colonel found when the weather finally permitted him to conduct his reconnaissance was a region "more alpine than Switzerland itself, and in its physical conformation perhaps the most extraordinary on the face of the globe .... For hundreds of miles around you will scarcely find a level spot twenty yards square.”23 The only way the colonel could see to prevent the marauding was to establish small posts throughout the region. He informed Wright, "In view of the limited number of troops that can be spared for service in this district, making any combined and extensive movement impossible, the policy I have thought it best to adopt is the establishment of posts, consisting of a single company each.”24 This was not a new strategy at all, but the hope was the establishment of new posts would make it more efficient to pursue and capture marauding tribesmen. ${ }^{25}$

${ }^{21}$ Ibid, 804.

${ }^{22}$ Whites committing atrocities was not new, of course, and in June department officials became aware of one of one of the local whites' more odious activities: "parties of white men are engaged in stealing and carrying or selling into bondage the children of the Indians in the district." Lippitt's predecessor was ordered to "use all means in your power to prevent such infamous practice.” O.R., 50:1, 513

${ }^{23}$ Ibid, 906-07.

${ }^{24}$ O.R., 50: 1, 907-908.

${ }^{25}$ Glenn Thomas Edwards, "The Department of the Pacific in the Civil War Years,” (doctoral dissertation, Eugene, OR: University of Oregon, 1963), 116. 
Trying to find the responsible tribesmen long after an attack on an isolated ranch was virtually impossible, and scattering a handful of troops to the most exposed ranches was illogical, yet that is what Lippitt ordered. ${ }^{26}$ Despite the arduous nature of the pursuits and the difficulty in finding those responsible for the endless attacks, the California troops did manage to capture some 800 Native Americans, mostly innocent, non combatants. ${ }^{27}$

Dealing with the captured tribesmen and women created a different set of problems for the troops stationed in the Humboldt District. Housing and feeding, ostensibly the responsibility of the Indian agent, George Hanson, fell to the military until the captured persons were placed on one of the region's reservations. That, however, did not end the military’s responsibilities toward the Native Americans. Troops had to be stationed near reservations in an effort to protect the Indians from local whites and to try to prevent many Native Americans from escaping, which they did in large numbers. ${ }^{28}$ All in all, service in the Humboldt District was difficult and ceaselessly frustrating in an area with rugged terrain that made operations arduous and which favored the tribesmen.

Just how difficult it was to battle the Native Americans in the region is clear from the allocation of troops to the district during the war. The first return after Lippitt assumed command in January 1862 shows that he had at his disposal 438 officers and men, which was roughly eight percent of the department's available manpower. ${ }^{29}$ To
${ }^{26}$ Ibid, 118-119.
${ }^{27}$ Ibid.
${ }^{28}$ Ibid, 120.
${ }^{29}$ O.R., 50: 1, 1168. 
fully comprehend the disproportionate number of troops stationed in the Humboldt District it is important to note that the other three districts that then made up the Department of the Pacific encompassed one or, in the majority of cases, two modern states. Furthermore, the number of troops allocated to the Humboldt District over the course of the war demonstrates the ebbing and flowing of violence between the regional tribes and the white populace. After some initial success in the early part of 1863, the situation again deteriorated to where there were almost 800 troops in the district on December 31, 1863. That number represented almost twenty percent of the Department of the Pacific's manpower at the time. ${ }^{30}$ Continued success eventually resulted in the defeat of the various tribes, followed by their removal to reservations, thus by the end of the war just 190 officers and men were stationed in the Humboldt District. ${ }^{31}$ Unfortunately for George Wright, and his successor, Major General Irvin McDowell, the Humboldt scenario was not unique in the vast department, in that dealing with militant, or out and out warring tribes, proved difficult, costly, and with success often coming slowly. A situation all too similar to that in the Humboldt District drew other department forces to the opposite part of California in early 1862. The Owens River Indians, like the various tribes in the Humboldt region suffered increasingly at the hands of encroaching whites. Despite the increasing number of whites in the Owens River valley, the tribe still outnumbered them at the outset of the Civil War. This meant that sustained uprisings threatened the vary existence of all the white farmers and ranchers in the region. The only solution, or at least the only one considered by the
${ }^{30}$ O.R., 50: 2, 711.
31 Ibid, 1272. 
farmer and department officials, was to use troops to suppress the uprisings and force the tribe into a peace treaty.

Desperate times during the winter of 1860-61, due to food shortages, precipitated the cycle of violence that plagued the valley well into 1863. The call for troops finally resulted in the dispatch of a 40 man reconnaissance force being sent to investigate in March 1862. ${ }^{32}$ It was the opinion of Colonel James Carleton, who commanded the District of Southern California, that

Since the Washoe and Coso mines have been discovered, people have gone into this valley with stock, to be convenient to the mines for the sale of beef and [et]c., and the poor Indians are doubtless at a loss to know how to live, having their fields turned into pastures whether they are willing or not. It is very possible, therefore, that the whites are to blame. ${ }^{33}$

White depredations against the tribesmen and women exacerbated the deteriorating relationship. General Wright agreed with Carleton's assessment, explaining to the United States Adjutant General in Washington D.C. "Reports from that country represent that the whites were in the wrong [having murdered four Indians], but I cannot let the innocent suffer for the guilty. I am compelled to send troops to preserve the peace.”34 Regardless of who was at fault, it was his job to maintain the peace; therefore, he ordered additional troops to descend into the valley from Fort Churchill, Nevada Territory.

32 O.R., 50: 1, 939. Part of the reason troops were not sent to investigate sooner was that the condition of the roads made any such effort virtually impossible, and thus district commander Carleton kept the force he later sent not far from the small town of Los Angeles. Ibid, 825.

33 Ibid, 936.

${ }^{34}$ Ibid, 967. 
Although most of the department's high command believed whites were largely to blame for the unrest, they had little choice but to use force to compel the Native Americans to submit to governmental authority and to desist from further attacks. As was the case in the Humboldt District, there were no quick solutions. The initial effort to confront and defeat the marauding Indians began in March, when Lieutenant Colonel George Evans left Los Angeles with three companies of the Second California Cavalry and headed toward the Owen's River valley. Once in the valley, Evans found "that the settlers had for some considerable time been threatened by the Indians, and been hemmed in at The Fort [a semi fortified complex, at the heart of which was a general store],” where they were threatened by several hundred tribesmen. ${ }^{35}$ The Native Americans, who battered a home guard just before Evans arrived, fled into the steep hills rimming the valley upon the military's arrival. Disinclined to make easy targets of themselves, the Indians remained among the rocky slopes, eventually forcing Evans, now joined by the civilians and a contingent of California troops sent down from Fort Churchill, to attempt to dislodge them by force. The effort proved futile, and costly, leading the colonel to admit, "I saw that it would be madness and no less than murder to attempt to go any farther: that I could do nothing but get half of my men killed without as much as getting a fair shot at an Indian."36 Two days after the failed attempt to dislodge the tribesmen from their natural bastions, Evans and his command began a slow withdrawal, leaving the Owen's River Indians in control of the valley. The 41-day campaign failed entirely,
${ }^{35}$ Ibid, 46.
${ }^{36}$ O.R., 50: 1, 46. 
which meant more men and more material would have to be put into the field to bring the depredations to a close as soon as possible. ${ }^{37}$

Eager to see the natural resources in the region developed, Wright sent orders for a second expedition to start as soon as practical. Since the responsibility for defeating and forcing a peace settlement on the tribesmen again fell to Lieutenant Colonel Evans and his contingent of cavalrymen, the need for recuperation prohibited any alacrity in preparation.

Once Evans’ command was finally ready in June, it again worked in conjunction with a smaller contingent of troopers moving southwestward from Fort Churchill. Just as in the previous case, there were difficulties in executing the pincer-like strategy. Wright, himself, caused a good deal of confusion by issuing dissimilar orders to the separate wings of the movement. As Evans noted in his report, he learned that the other force, under Captain Edwin Rowe, “was acting under orders from headquarters Department of the Pacific and endeavoring to make peace with the Indians, while I was under instructions to chastise them severely."38 There was method in Wright's madness, however, as Evans’ forces “commenced killing and destroying whenever I could find an Indian to kill or his food to destroy,” it “changed their [recalcitrant Indians] tune and were anxious for peace.”39 With Evans destroying homes and crops, and occasionally exchanging shots with the Native Americans, while Rowe wrangled peace agreements,

37 Ibid, 1038. In a communication to Colonel Ferris Forman Wright revealed his disbelief that Evans had failed, telling the colonel, "I of course gave no credit to the vague rumors of his defeat, or of his failing to accomplish fully the object of his movement."

38 O.R., 50: 1, 148.

39 Ibid, 149. 
the second effort proved more successful than the first, and a degree of peace returned albeit momentarily - to the valley by mid July $1862 .{ }^{40}$

Part of the cost guaranteeing peace included assurances that provisions would be provided for the reconciled tribesmen. The food was the key issue since white destruction of Native American food supplies precipitated the retaliatory violence, theft of livestock, and raiding. As was all too commonly the case when the U.S. government and its agents dealt with the Native Americans throughout the 1800s, those promises proved hollow, or at best insufficient. The lack of the promised food rations reignited the conflict between whites living in the Owen's River valley region and local Indians in mid 1863. In response to a new round of calls for assistance, General Wright ordered another expedition to chastise the Indians once and for all.

Fortunately for George Wright, the latest effort fell upon the shoulders of someone other than Colonel Evans, who seemed confounded by the challenges of trying to defeat an elusive enemy over rugged terrain. This time around the Indians faced a far more aggressive and hardened officer in Captain Moses McLaughlin. Pragmatic, brutally efficient, and utterly honest, the captain understood the situation entirely. In his view, "Mr. [John P.H.] Wentworth, Indian agent for this district, has been most undoubtedly the cause of the present difficulties and .. . has been shamefully negligent of his duties.” Captain McLaughlin bluntly informed department headquarters that "Mr. Wentworth promised everything, gave nothing, and the results have been the destruction of life and property." ${ }^{41}$ Despite understanding that undelivered promises were the cause of the

${ }^{40}$ O.R., 50: 2, 91. The treaty ending the fighting, for the time being, was signed on August 28, 1862.

41 O.R., 50: 1, 212. 
troubles, McLaughlin believed that peace meant the permanent subjugation of the warring Indians, and he went about that work in a manner reminiscent of how George Wright conducted his 1858 campaign in Washington Territory.

In a demonstration of cold, calculating efficiency, at dawn on April 19, McLaughlin and roughly 20 of his 50 troopers surrounded a Native American encampment along the Kern River, which is adjacent to the Owen’s River valley. After gathering all the males together, he asked some local citizens who accompanied his force, as well as an Owen's River chief named Jose Chico, who acted as guide, to point out all the tribesmen for whom they could personally vouch for as being "good.” After the process was finished, "the others, to the number of thirty-five, for whom no one could vouch, were either shot or sabered. Their only chance for life being their fleetness, but none escaped." 42 The captain explained his savage actions to department headquarters as being necessary, adding that "I feel certain that a few such examples will soon crush the Indians and finish the war in this and adjacent valleys.” Furthermore, he prophesied, “They will soon learn that . . . with the forces here they will soon either be killed off, or pushed so far in the surrounding deserts that they will perish by famine.”43

General Wright, desperate for good news regarding relations with the Native Americans within his department, welcomed McLaughlin’s report. After reading the captain’s account, Wright expressed “his admiration of the energy, perseverance, and good conduct displayed by yourself and your command throughout the whole
${ }^{42}$ Ibid, 209.
${ }^{43}$ Ibid. 
campaign.”44 That Wright had no qualms about McLaughlin murdering 35 Indians is understandable for three reasons: first, as McLaughlin predicted, the word of his willingness to act in such a manner spread throughout the remaining bands, leading most of them to agree to end the fighting; second, as the commander of a vast department with a multitude of responsibilities, anything that quelled any unrest, no matter what the nature, was good news to Wright; finally, since Wright had, himself, summarily executed warring tribesmen and slaughtered their entire herd of ponies to bring about a quick end to the 1858 war in the Pacific Northwest, he was not as squeamish as some of his subordinates. $^{45}$

As a final compliment to the captain, department headquarters also informed him that the Indian agent had been ordered to provide food supplies for the Native Americans who turned themselves over to the cavalry and, if possible, to establish an encampment for them far from the Owen's River valley. This latter point, which did not happen for some time, was based on the premise that if the Owen's River and allied tribes were removed from far enough from their homelands they would be less likely to try to escape and return to the region. In a final move to help protect the whites from marauding tribesmen and the Indians from unruly whites, a cavalry company remained in the valley at Camp Independence.

The calm that settled into the Owen's River valley by late summer 1863 more or less prevailed to the point where Wright, forced to move his forces around like chess

44 O.R., 50: 2, 473.

45 Three years earlier, during the 1858 war in eastern Washington, Wright hanged eleven captive Indians, and slaughtered 100s of their horses. Carl P. Schlicke, General George Wright: Guardian of the Pacific Coast, (Norman, OK: University of Oklahoma Press, 1988), 181-183. 
pieces, removed the troops from Camp Independence in September. Denuded of their security blanket, local citizens petitioned Wright’s successor, Irvin McDowell, for the reoccupation of the camp a year later. Fortunately for the civilians, a greater degree of calm reigned throughout the department as the end of the war neared. Thus, McDowell was able to assuage their fears by having Wright, now the District of California commander, order the reoccupation of the post in December. ${ }^{46}$

Although the violence in the Owen's River valley, both in duration and cost, paled in comparison to what transpired in the Humboldt region in the far north of the state, both typified one type of the difficulty faced by the officers and men of the Department of the Pacific during the war. Increasing numbers of whites competing with Native Americans for finite lands all too frequently led to violence, and that in turn almost always led to pleas for assistance once the civilians stirred up the Indians beyond what they could handle. Although regular Army officers like Wright and Carleton understood that the whites were generally to blame for the violence between the two groups, their job was to ensure the tribesmen were pacified to the point that they could not impede the development of the lands by white settlers and miners. In both the Humboldt District and in the case of the Owen’s River valley campaigns, the military faced an enemy accustomed to the terrain, who was highly mobile, but within a fairly well defined area (albeit the Humboldt region was massive), which required a significant outlay of men and equipment.

${ }^{46}$ McDowell deferred to his predecessor's view of the situation and followed Wright's suggestion to reoccupy the post. Having served in the region for well over a decade by then, Wright understood the true nature of things when he informed McDowell, "The petitioners do not set forth any actual hostilities, and simply ask for the troops in the valley as a precautionary measure. However, to allay their apprehensions I would recommend that a company of Nevada Infantry be sent.” O.R., 50: 2, 1080. 
If fighting a guerilla war against an enemy accustomed to the terrain proved difficult at best and maddening at the worst times, at least officers like Lippitt, Evans, and McLaughlin could be thankful they knew generally where to find their enemy. Knowing essentially where the raiding tribesmen were was not a luxury enjoyed by the officers and men trying to protect the steady flow of immigrants into the Far West. With literally hundreds of thousands of square miles to guard, the Humboldt and Owen's River operations appear almost sedentary in comparison to the responsibilities faced by officers patrolling the open spaces of Oregon, and Idaho and Utah Territories. ${ }^{47}$

The difficulties in dealing with the semi nomadic tribes along the immigrant trails were not new, but each year since the discovery of gold in California in 1848 the situation deteriorated. As the initial gold rush subsided and gave way to widely separated gold and silver rushes throughout the Far West more and more people trekked across the often inhospitable lands between Missouri and the Pacific slope, in search of better lives. The mounting pressure that arose as competition for lands traditionally held by Native Americans increased grew even worse after the Civil War began. With more people heading west to escape the war, looking to establish homesteads, seek their fortunes through mining, or by mining miners, the frequency of confrontations between whites and Native Americans accelerated. Given the increasing numbers of immigrants combined with the reduction in the number of troops serving in the Far West and along the immigrant trails, the escalating violence was inevitable.

The experiences of the Van Orman party in September 1860 illustrate the growing danger along the immigrant trails on the eve of Civil War. Near the end of the

47 Wright's activities in 1858 in eastern Washington Territory, which included the panhandle of Idaho until the territory was created, more or less ended any serious unrest until the 1877 Nez Perce war. 
travel season, not far from Salmon Falls, Washington Territory (now the state of Idaho) a large group of Shoshonis attacked the Van Orman's 44 person wagon train. ${ }^{48}$ After 34 hours of fighting, the survivors abandoned their wagons and fled. The Shoshonis took up the trail after plundering the wagons. The outcome was predictable; the Native Americans easily overtook the jangled men, women, and children, most of whom eventually perished. News of the attack spread quickly after one, and then two additional, survivors reached safety by October 2. Two days later the future Department of the Pacific commander (then) Colonel Wright ordered a 100 man rescue party in search of possible survivors. Ultimately the soldiers found 12 more survivors, who sustained themselves by eating the corpses of four children. ${ }^{49}$ Being so late in the season, no punitive expedition could be launched before snow made it impossible; therefore, Wright devised a plan for the coming spring.

Of course by spring 1861 the nation was in a state of civil war and any such retribution was entirely secondary to the need to strengthen the Union military. Even though no military operations were launched, the Van Orman party's fate cast a long shadow, especially given the fluctuating strength of the military in the region and its expanded responsibilities. Given the prevailing state of confusion and the brief tenures of the Department of Pacific's first two commanders any aggressive steps to protect the immigrant trails would have to wait. It was not until George Wright assumed command

48 The Shoshonis, who encompassed a number of bands over a very large amount of territory in the Utah, Idaho, Oregon, Nevada region, were universally known as Snake Indians at that time.

49 Schlicke, 209-211. 
of the department that steps were taken to address the dangers along the immigrant road (and the mail and telegraph route). ${ }^{50}$

The desperate concentration of as many of the Regular Army troops as possible in the east meant that a number of posts in the Far West were closed or at best left with a skeleton contingent until the first volunteers could replace them. Since Albert Sidney Johnston oversaw a department focused on concentrating its forces, and Edmund Sumner's chief objective was dispersing those troops, it fell to Wright to replace the departing Regulars with a virtually all-volunteer command. That process also meant deciding which posts remained open, and eventually where to place new facilities. Although the Department of the Pacific had more men at its disposal than the same region prior to the war, the enhanced responsibilities actually left department officials trying to achieve more with a vastly inferior force.

On December 30, 1860, the Departments of Oregon and California, which were soon combined into the Department of the Pacific, were manned by 2,245 troops, present for duty. Those troops were stationed at 26 installations throughout the vast territory. As of June 30, 1861, with the first major battle of the war just a month away at far off Manassas, Virginia, Edmund Sumner commanded 2,064 men in the field. ${ }^{51}$ Both Sumner and his predecessor, Johnston, spent the months between January and June strengthening the coastal defenses. As a result, they also closed two posts and left skeleton contingents at most of the Pacific Northwest garrisons. Thus, although the department had sent only

50 Wright's appointment was fortuitous because of his keen knowledge of the complexities needed when dealing with the Northwestern tribes, but it also created problems because his removal from command of the District of Oregon left an experience void that could not be filled.

51 O.R., 50: 1, 428-430. 
a small number of its strength to the active theatre of the war by June 30, there had already been a major reduction in the number of troops along the immigrant routes and lightly inhabited areas.

The most dramatic changes to effect the department took place during the last six months of the year, when virtually all the Regular Army troops left for the eastern battlefields and were replaced by volunteers. When Edmund Sumner left the department in October, Wright was elevated to department command, and thus became the recipient of requests, and sometimes frantic pleas, for redeployment of troops to protect regions ranging from southern California to Gray’s Harbor, Washington Territory. Between June and the end of December 1861 civilians and/or politicians sent eight requests for military protection. In one case, the petitioners pointed out that certain Native Americans attacked settlers and those passing along the various trails "with impunity from their knowledge of the smallness of the force at this place.”52

Although replacing veteran units with raw volunteers hardly seemed like a positive move for citizens living in the Far West, there was an upside to the transition. By the end of 1861 Wright's commanded twice as many troops as had been in the department just six months earlier. Of course, a disproportionate number of those troops were stationed along the coast and furthermore, the increased numbers had to be spread among five more posts than had been the case in June. With Indian wars heating up in both the far northern part of California as well in the east-central part of the state, and requiring a greater outlay of troops in those regions, Wright found himself unable to allocate troops commensurate with the needs along the immigrant trails, mail and

${ }^{52}$ Ibid, 631. 
telegraph routes, and near the booming mining districts. The effort to placate nervous civilians, as well as regional and national political leaders regularly led to the establishment of additional posts, manned by smaller and smaller contingents.

Despite the dangers of spreading an insufficient command dangerously thin, Wright found himself doing just that to ease the politicians' raw nerves. Each year, the troops were spread to more and more posts, which did place troops in a greater number of areas, but in smaller numbers at those places. This strategy reached its pinnacle in June 1864, the height of the war, both in the Far West and in the main theatre, when Wright's command consisted of just 3,933 troops dispersed over 46 posts throughout the department. To give some perspective to just how comparatively thin the troops were spread, one need only consider that there were roughly 1,700 more troops in the department than three and a half years earlier, but those troops manned 20 additional posts, almost a one hundred percent increase in the number of facilities operated by the military. ${ }^{53}$

The greatest challenge facing Department of the Pacific officials trying to protect immigrants, miners, and the communication routes in the wide open regions was the need to overawe any marauding tribes or any that felt pushed to such actions. Even with the establishment of 20 additional posts (that number shrank from a high of 46 to 42 by the end of 1864, but bounced back up to 44 the following June) department leaders found it difficult to defeat the roving bands of tribesmen who attacked immigrants on the trails and the miners that poured into the District of Oregon. The solution appeared simple in

${ }^{53}$ O.R., 50: 1, 428-430 and O.R., 50: 2, 883-885. It is also important to understand that a disproportionate number of troops were stationed in and around San Francisco -far more than the years prior to the war -so that a large percent of those 1,700 additional troops were not stationed along the frontier. 
theory, but difficult in practice; the best way to thwart attacks was to establish temporary posts or permanent forts along the most dangerous regions and to send patrols to protect civilians and frighten the Indians. When attacks occurred, expeditions specifically designed to seek out and punish the perpetrators took to the plains.

The attacks occurred most often in what are now southeastern Idaho, northern Utah, and eastern Oregon, regions inundated with immigrants and miners. This was not a new phenomenon, and in fact, during the 20 years prior to the Civil War, the vast majority of murders along the immigrant trails took place in this loosely defined area. ${ }^{54}$ Somewhat oddly, or at least rather coldly, the War Department's initial concern was not for the lives of the immigrants or even the miners who helped strengthen the nation's economy, but for keeping the mail and telegraph lines between the coasts open.

Despite numerous offers from the various state militia commanders, the War Department steadfastly refused to accept any of California's militia units directly into the Union army. However, with the removal of the Regulars and fears about the safety of the thin ribbon that connected the East with the gold rich Far West, the Secretary of War, Simon Cameron, finally sought aid from the politicians. Accordingly, on July 24, 1861, Cameron notified the governor of California that Department of the Pacific officials would shortly call for infantry and cavalry volunteers to serve not in the East as most hoped, but in the inhospitable regions of the Far West. The sole purpose of those volunteers was to protect the Overland Mail Route in Utah Territory, which could hardly be considered a quick path to glory and prestige. ${ }^{55}$

54 Irving Merrill, “The Civil War in the West: The 1864 Trail Season,” Overland Journal, 9: (1991) 4, 23.

55 O.R., 50: 1, 543. 
This initial step eventually led to the raising of some 17,000 Californians in eight infantry and two cavalry regiments before the war ended. More importantly for the mail service and, almost as an afterthought, the immigrants traveling through northern Utah and southeastern Washington Territory, this first call resulted in a war-long military presence in Utah Territory. The California soldiers and troopers that marched into Utah in August 1862 found themselves chasing recalcitrant Shoshoni and Bannock Indians across the northern part of the territory and into what became Idaho Territory in 1863.

Colonel Patrick Connor, a gruff Irish native and veteran of the Seminole and Mexican wars, who disliked Utah's Mormons, led the 700 or so Californians in the District of Utah, the command of which he assumed in August 1862. ${ }^{56}$ During the course of the war, his principle responsibility was keeping the mail and telegraph routes open and protecting immigrants heading west. The far-flung nature of this task led Connor to spread his forces to widely separated points throughout his district. From these posts, which included Forts Churchill and Ruby, Nevada Territory and Fort Bridger and Camps Douglas and Connor, Utah Territory, Connor’s California troops initiated patrols, escorted both immigrants and mail coaches, and carried out offensive campaigns to capture or kill those Native Americans that haunted the trails and way stations. Most troubling for Connor were the Shoshoni and Bannock tribesmen, who regularly attacked and often killed postal carriers, miners, and immigrants along the Idaho - Utah border. ${ }^{57}$

${ }^{56}$ Warner, 87-88. The District of Utah included much of the state of Nevada, which entered the Union during the war.

${ }^{57}$ Utley, Frontiersmen in Blue, 222-223. 
Asserting military control over marauding Indians in such a vast region proved virtually impossible, and led Connor and his subordinates to use the murder of captured Native Americans as a tactic to break the spirit of the roving tribesmen. In an effort to exert early control over his district, Connor ordered a company of California cavalry to traverse a lengthy section of the Overland Mail Route searching for hostile Indians beginning on September 30, 1862. The leader of the patrol, Major Edward McGarry, employed extreme measures to instill fear in all regional tribes, hostile and otherwise. Connor told McGarry, that if he captured any Indians he believed guilty of killing immigrants to "immediately hang them, and leave their bodies thus exposed as an example of what evil-doers may expect while I command in this district."58 Following Connor's orders rather closely, the major's command killed a large number of captured, unarmed Native American braves who, according to McGarry, attempted to flee.

Furthermore, he recounted for Connor that

I put to death four of those [Indians being held by his force] remaining, and released the squaws and child, telling them that we were sent there to punish Indians who were engaged in the massacre of emigrants, and instructed them to tell all the Indians that if they did not desist from killing emigrants I would return there next summer and destroy them. ${ }^{59}$

These tactics, as brutally effective as they might appear, did not end the raids and killing. In fact, the largest pitched battle between Native Americans and Union military forces to take place during the Civil War occurred in late January 1863, just over the Idaho side of the border with Utah. Indicative of just how important he believed it was to crush the powerful band of Shoshonis led by chief Bear Hunter, Connor took the unusual
58 O.R., 50: 2, 144.
59 O.R., 50: 1, 178-179. 
step of initiating a winter campaign in the rugged country along the Utah - Idaho border. Marching out from Camp Douglas, near Salt Lake City, on January 24, Connor led roughly 300 California infantry and cavalrymen northward toward the Bear River, and the climactic confrontation he sought.

The Union force arrived opposite the Indian encampment shortly before dawn, January 29. Connor ordered all available forces to ford the river and take positions so as to cut off any retreating tribesmen. With about two thirds of his force in position shortly after dawn, the Californians attacked. The Shoshonis, well-established behind the undulating landscape and brush, put up stout resistance at first, but the soldiers were able to turn both of their flanks, forcing some of them to give up their protective cover. Once flushed from their position among the rocks and brush, they became easy targets. As Connor reported, "those who did escape from the ravine were afterward shot in attempting to swim the river.” With 224 Native Americans killed and the survivors captured and 20 soldiers killed or mortally wounded with an additional 48 others less severely wounded, Bear River ranks as a battle when skirmishes were the norm. ${ }^{60}$

Despite getting a congratulatory note from the, commanding general of all Union forces, Major General Henry Halleck, the raiding continued, but on a more sporadic basis, and travel on the immigrant trails and Overland Mail Route was safer, if not exactly safe. $^{61}$ Even if Connor did not gain as decisive a victory as he hoped, the victory in a pitched battle dramatically weakened the regional tribes’ will to fight. Unfortunately for Connor's neighboring District of Oregon, the military never forced the raiding Indians

60 The sources for this paragraph include, Utley, 223-224; O.R., 50:1, 185-187; Ray Colton, The Civil War in the Western Territories, (Norman, OK: University of Oklahoma Pres, 1984), 164-165.

61 O.R., 50: 1, 187. 
into a pitched battle. This, in turn, meant Brigadier General Benjamin Alvord, who commanded the district for the majority of the war, never weakened the power of the tribes in his district in one blow. For Alvord and the troops assigned to the District of Oregon, which included Washington Territory, out of which grew Idaho Territory, the war became a chess game between Indian raiders and the military.

Although Alvord eventually had the First Oregon Infantry Regiment, a few California Infantrymen, and the First Washington Territorial Infantry Regiment under his command, the task of addressing any troubles with the Native Americans along the immigrant trails and in the mining districts fell primarily to the First Oregon Cavalry Regiment. For four years the First Oregon Cavalry troopers fanned out from posts scattered across the eastern portion of the district in its efforts to perform the tasks assigned it. ${ }^{62}$ During that time its troopers rode tens of thousands of miles in pursuit of its primary objective: "To prevent the outbreak of hostilities, protect settlers, and secure justice on either side, for the preservation of amicable relations it is expected that the force under your command is mainly to be employed."63

The first opportunity to actively carry out these responsibilities did not occur until August 1862, when the first of many similar expeditions over the course of the next three years left Fort Walla Walla. The first expedition exemplified one of the common actions carried out by the Oregon troopers during the war. On August 9, Captain George Currey

\footnotetext{
${ }^{62}$ The primary base of operations along the immigrant trails and mining regions was Fort Walla Walla, in what is now the southeastern corner of Washington state. Oregon troopers as well as Washington Infantrymen manned other posts in these wilderness regions, including Fort Colville (northeast Washington), Fort Dalles (north-central Oregon), eventually Fort Boise (southern Idaho), Fort Lapwai (west-central Idaho), as well as a number of temporary camps established as necessity required. The station assignments in the District of Oregon can be found in all the biennial returns (June 30 and December 31, of each year) in the Official Records, volume 50, parts 1 and 2.

${ }^{63}$ O.R., 50: 1, 1085.
} 
received orders to lead an expedition consisting of his own Company E from Fort Walla Walla to apprehend the leaders of a small group of Indians threatening local whites in the Grande Ronde Valley, Oregon. Early on August 12 Currey’s troopers surprised the Indian leader, called Dreamer, in his tipi, where they planned to hold him until dawn. Eventually a melee ensued and Dreamer and three other Indians were killed by Currey's soldiers. ${ }^{64}$ Despite the unfortunate outcome (the objective was to arrest the leaders, not kill them), Colonel Justus Steinberger, the leader of the First Washington Infantry, informed the District of Oregon commander, "the immediate punishment served, has, I think, produced a salutary effect for their future good conduct. It convinces them of the determination and ability of the Government to protect its citizens." ${ }^{65}$ The colonel's wishful thinking aside, depredations against whites not only continued, but worsened as the war dragged on.

On the morning of May 4, 1863, the largest expedition organized in the District of Oregon during the war left Fort Walla Wall, beginning a long, arduous, and, in many ways, largely fruitless push into Idaho Territory. The force, led by Colonel Reuben Maury, consisted of Companies A, D, and E, First Oregon Cavalry, and numbered over 200 troopers. Before the campaign ended months later, elements of the First Washington Infantry joined the command in the field. The troopers' primary goal was to prevent the Shoshoni Indians from attacking the immigrants traveling the trails that led to Oregon and Washington Territory, with a secondary goal of providing muscle for a treaty commission then negotiating a new treaty with the powerful Nez Perce bands. The sheer
${ }^{64}$ Ibid, 164-166.
${ }^{65}$ Ibid, 164. 
size of the force attests to district commander General Alvord's determination to ensure the safety of the immigrants and his desire to easily crush any Native American combatants it should encounter. ${ }^{66}$

The campaign got off to a positive start when the Indian agents and governmental negotiators attempting to open Nez Perce lands to miners successfully used elements of the force to overawe some of the Nez Perce leaders. By using a show of force, at the appropriate time, the government negotiators intimidated some of the Nez Perce leaders, thereby reducing the lands held by the Nez Perces to a fraction of the size as determined by the 1855 treaty. ${ }^{67}$ This success, though important due to the presence of white miners scouring the Nez Perce lands looking for gold, was not the primary objective, and thus, on June 15 the combined force pressed further south. ${ }^{68}$

In some important ways, the command's role in the Nez Perce negotiations proved to be a harbinger of things to come over the next several months. In fact, the troopers encountered more tribesmen during their stay around the treaty party than they did during the rest of the expedition combined. Just as they fortunately did not need to resort to a use of arms against the Nez Perce, Colonel Maury’s troopers never fired a shot at a "hostile” Indian until nearly the end of the campaign. Given that Maury instructed his subordinates to arrest and hold tribal headmen, impress upon all the Native Americans encountered of the importance of maintaining peace (conveyed in a lightly veiled threat

${ }^{66}$ The expedition into the Snake country, as it was termed in the official reports, represented 25\% of the district's available force, an incredible commitment considering the District of Oregon's vastness. O.R., 50: 2, 505.

${ }^{67}$ Alvin Josephy, The Nez Perce Indians and the Opening of the Northwest, (Boston and New York: Houghton Mifflin Company, 1997), 415.

${ }^{68}$ Ibid, 50: 1, 215. 
of retribution), and "to attack in case of finding any considerable force of them [Indians]," the general absence of contact with the Shoshonis is telling. The plain fact is that after three months traversing the open prairies of Idaho Territory none of the expedition could say they had encountered a hostile tribesman, or any Native Americans for that fact. ${ }^{69}$ This prevailing calm, although good for the immigrants traveling the trails, did not sit well with some of the Oregonians.

In one dispatch to district headquarters, Colonel Maury's assessment of the continued inability to find any Native Americans interested in testing the mettle of his force is laced with the tincture of regret. By late September, after months in the field, the colonel predicted that he would not "succeed in finding any body of Indians of sufficient force to warrant me in attacking them; and in the case of the small parties that I may be able to capture, or that may come to my camp, I cannot possibly obtain such evidence as would warrant me in hanging them.. ${ }^{, 70}$ One of Maury's most active subordinates, the aforementioned Captain Currey, echoed his commander's strange regret, when he reported finally coming upon a Native American encampment. Currey’s force surrounded the camp, preventing any escape, and prepared to attack. However, before the soldiers initiated an attack, the band's chief "caused all his men to stand in a conspicuous place and show us that they were unarmed and did desire peace, by holding up their hands. Although we had then trailed the party for four days, one day without rations, I could not consent to fire upon an unarmed and supplicating foe.” His display of humanity notwithstanding, the captain forced the band to provide his men with salmon,

${ }^{69}$ O.R., 50: 1, 218. Maury did not encounter a single Indian until August 8, more than three months after departing Fort Walla Walla, and two months since leaving the treaty negotiations.

${ }^{70}$ Ibid, 222. 
and took their chief captive upon his departure the following morning. ${ }^{71}$ When the expedition finally came to an end on October 26, only Lieutenant James Waymire could report his troopers had actually fired upon (there seems to be significant doubt as to whether the Indians fired back) any tribesmen -killing four before the rest fled. ${ }^{72}$

The lack of confrontations could have been considered an example of a successful campaign, whether or not the Oregonians were disappointed by the lack of military action or not. However, as historian G. Tom Edwards pointed out, the reality was that the Shoshonis who attacked immigrants and miners understood the soldiers' tactics all too well. As he noted, Department of the Pacific officials followed the prevailing logic when conducting field operations, meaning that all field activity took place between late spring and mid fall. The various tribes understood this, and those attacking immigrants and miners melted into the wilderness, as far from the regions patrolled as possible, during the hot months. Thus, Maury's inability to find any of those perpetrating the attacks throughout the region is understandable -at least in hindsight. ${ }^{73}$

Despite what the men thought, the major 1863 expedition had been a qualified success, aided and abetted by the Native American's decision to avoid the military, if possible, during the warm months. Knowing that the calm was temporary, General Alvord, like his field officers, was not satisfied by the largely bloodless achievements of the 1863 campaign. He spent the winter season planning for a decisive campaign for the next spring. Unlike Colonel Maury’s disproportionately large, single campaign in 1863,

${ }^{71}$ Report of the Adjutant General of the State of Oregon, for the Years 1865-6, (Salem, OR: Henry L. Pittock, State Printer, 1866), 24.

${ }^{72}$ O.R., 50:1, 224.

${ }^{73}$ Glenn Thomas Edwards, “Oregon Regiments in the Civil War Years: Duty on the Indian Frontier,” (master’s thesis, University of Oregon, 1960), 50. 
Alvord planned to send two separate, yet sizeable, forces into the field in 1864. This time the objective was not the immigrant trails running through Idaho Territory, but the sparsely populated eastern portions of Oregon, from which rumors of gold strikes echoed, promising a rush of whites into an area already noted for predatory tribesmen.

According to Alvord's strategy, one contingent would leave Fort Dalles in northcentral Oregon (along the Columbia River) and press southward, while simultaneously another force of cavalrymen would leave Fort Walla Walla in the southeastern corner of what is now Washington state, moving southwestward. ${ }^{74}$ There was something of a pincer tactic to these joint operations, however, events prior to the traditional campaigning season complicated things in February.

Even though campaigning in the cold, wet months of winter and early spring was rare, regardless if one served in the Department of the Pacific or the Army of the Potomac, circumstances sometimes dictated active operations during the most inhospitable times. This was the case in February 1864, when civilians along the south fork of the John Day River pleaded with Alvord for protection. In response, a small contingent of cavalrymen, commanded by Lieutenant Waymire, left Fort Dalles to establish a camp near Canyon City, Oregon. Just three weeks after arriving in the area local citizens asked Waymire to help them recapture some 40 mules and horses stolen by an Indian raiding party, and to punish the tribesmen. Waymire and 18 troopers joined about 50 civilians in pursuit of the marauding Indians and stolen mules and horses. Finally making contact with a Native American encampment on April 6, the combined force was ambushed by a surprisingly large number of Indians, leading to the deaths of

\footnotetext{
${ }^{74}$ Ibid, 94-95.
} 
three soldiers, including a lieutenant. The number of tribesmen and their success in this initial fire fight disheartened the civilians who fell back, which in turn forced the remaining cavalrymen to retire as well. Given their enemy’s large force and the unexpected casualties, the pursuit ended and the rattled group withdrew, eventually returning to Canyon City. ${ }^{75}$

This was not the auspicious beginning to the 1864 campaign that General Alvord envisioned. Although Waymire's small command was not intended to act as part of the larger coordinated expeditions that served as the backbone of the 1864 strategy, Alvord somewhat begrudgingly admitted, "He has converted his humble task into a regular campaign into the Indian country, thus anticipating the operations which are confided to Captains Drake and Currey.”76 As Alvord explained in his report, Drake and Currey represented the heart of the effort to defeat any predatory Native Americans, thereby encouraging development of eastern Oregon, which included a number of mining districts. Each officer was to lead two sixty-day circuits into eastern and south-eastern Oregon. Alvord reminded Currey that "The mining camps already established on the Owyhee should be protected, and it is desirable to assist the whites in traveling over that whole region west and southwest of old Fort Boise.”77 The Drake and Currey forays represented both the modified approach to addressing the problems created by roving bands of Indian raiders and also the antiquated view of how to deal with such dangers at the same time.

75 William V. Rinehart, "With the Oregon Volunteers, 1862-6,” MSS., Portland: OR, Oregon State Historical Society, 15-16; Edwards, “Oregon Regiments,” 95-99; O.R., 50:1, 310-315.

76 O.R., 50:1, 310.

77 O..R. 50: 2, 814. 
On April 28, 1864, just ten days after Lieutenant Waymire concluded his unsuccessful pursuit of the Indian raiders, Captain Currey set off from Fort Walla Walla to assume his part in the campaign to rid eastern Oregon of hostile Native Americans. The captain’s initial force consisted of 91 Oregon troopers, accompanied by pack masters and 104 pack mules and eight wagons full of supplies; before the campaign concluded Captain Edward Barry and a contingent of 31 infantrymen from the First Washington Infantry joined Currey’s force. ${ }^{78}$ Rounding out Currey's force were 10 members of the Cayuse tribe, who were recruited by their war chief, Umahontilly, after "a war dance was set on foot, and for hours the hideous yell and horrid pantomimoes [sic] peculiar to the war dance of that race rendered my camp both a lively and appropriate scene.”79 The campaign, which lasted six months and resulted in Currey's command crossing well over a thousand miles of mountain ranges, high plains prairies, and alkali flats, covered the full length of eastern Oregon and even extended into Nevada. ${ }^{80}$

Currey’s objective was plain: to clear out all hostile Indians from eastern Oregon, thereby making it more likely that if the rumors of gold discoveries proved true, they would be exploited, and to keep records of the largely unknown lands he marched over. Captain Currey went about his task with a ruthless determination that bordered on a fanatical desire to rid the region of virtually all Indians, regardless of their culpability in

\footnotetext{
${ }^{78}$ O.R., 50:1, 317; Report of the Adjutant General of the State of Oregon, 32; Edwards, "Oregon Troops," 104.

79 Report of the Adjutant General of the State of Oregon, 30.

80 On July 2, Currey calculated that his main force had traveled 813 miles, which did not include the additional scouting missions that broke from the main line of march. Six weeks later he estimated that his force had covered an additional 500 miles. O.R., 50:1, 319-20, 325.
} 
attacks on whites. ${ }^{81}$ Finally, after a slow start, on May 16 local citizens informed Currey that about 150 Shoshoni Indians were fishing on the Owyhee River. The captain cheerfully informed district headquarters of his plans: "I will move forward with the cavalry in the morning, clear the river of any Indians who may be found on it .... I hope to be able to bring my men under fire within five days of this.” ${ }^{82}$ Unfortunately for Currey, he missed the opportunity to disperse or kill the reported Indians. The command finally came into contact with a small group of Indians, also engaged in fishing, on June 3, which upon "seeing us they attempted to escape -killed them and moved up the creek in search for more, but only found one -killed him and returned to Camp Henderson.”83 One of the truly humorous incidents that took place during Currey’s determined expedition occurred on June 8. On that day a settler frantically informed the captain of the close proximity of a band of mounted, armed Indians. This information led Currey to order some of his weary men back into their saddles at sundown. “On arriving” where the settler indicated, Currey "satisfied myself that it was my own Indian scouts who had accompanied me,” and, the captain had to rather comically admit, “in fact, my night ride was a forced march in pursuit of myself!”,84

Up to this point Currey’s expedition proceeded independently of all other commands besides the infantry which he amalgamated into his force. However, the

81 Currey very militarily explained that he was not bound to any specific pattern of march because the "Snake Indians being my objective point," he went where he found them. Report of the Adjutant General of the State of Oregon, 32.

82 O.R. 50:1, 318.

83 Report of the Adjutant General of the State of Oregon, 36, 38-39. Camp Henderson was 330 miles from Fort Walla Walla.

84 Ibid, 39. 
spectre of Waymire's earlier foray combined with frantic appeals for protection from massed hostile Indians led Alvord to issue orders for the merger of Currey’s and Drake's commands near Harney Lake. Owing to the difficulty in trying to coordinate two forces in the lightly inhabited expanse of eastern Oregon, Alvord's orders, though issued in early May, proved difficult to fulfill. When Currey's command reached Harney Lake on June 28 and did not find Drake’s troopers, the captain felt "somewhat disconcerted in not finding Capt. Drake.” ${ }^{, 55}$ The junction of the two forces occurred three days later.

Like Currey, Captain John Drake had orders to clear a different section of eastern Oregon of marauding Indians, protect the miners and immigrants, and to take note of the territory through which his command traveled. On April 20 Drake led Companies D and G, First Oregon Cavalry south from Fort Dalles, taking up a more or less southerly line of march. His command numbered 119 troopers along with roughly 40 civilian pack masters. Like Currey, he, too, induced Indians, from the Warm Springs Reservation, to join his force and act as scouts. ${ }^{86}$ Drake’s first opportunity to clear out hostile Indians occurred on May 17 when some of his scouts reported the nearness of an encampment of nine lodges and approximately 30 Native Americans. Determined to strike, Drake ordered 39 troopers, led by Lieutenant John McCall "to make a night march, surprise their camp at daylight the following morning and attack at once without preliminaries." ${ }^{87}$ Lieutenant McCall divided his force, including some 20 Indian scouts, to attack from three sides, but the coordination failed and the results paralleled those experienced

${ }^{85}$ Ibid, 41.

${ }^{86}$ John M. Drake, edited by Priscilla Knuth, “Cavalry in the Indian Country, 1864,” Oregon Historical Quarterly (1964), 65: 1, 20-21.

${ }^{87}$ O.R., 50:1, 330 and 345; Drake, 32. 
by Lieutenant Waymire six weeks earlier. One element of the cavalry force struck the camp before the other two were in place, thus enabling the warriors to fall back to a strong position; "a complete fortification, strongly barricaded with large boulders, and with the appearance of having been prepared for the purpose, probably at some time past.” ${ }^{\prime 8}$ The lack of coordination proved costly as the tribesmen unleashed a concentrated volley into the one attacking force, killing Lieutenant Stephen Watson and two troopers, while wounding five other troopers and the leader of the Indian scouts, Stock Whitley. ${ }^{89}$ McCall initiated a rapid retreat and sent out riders in search of Drake and reinforcements, which arrived at 9:00 am, or roughly five hours after the attack. Drake's arrival ended any interest the Shoshonis had in continuing the fight.

Although the band fled upon Drake's arrival and evaded all efforts to track them down over the next two days, he could take some comfort in having captured their camp, which was full of plundered goods and provisions. Before falling back to a hastily created supply base along his line of march, Drake had all the captured goods of use distributed among his men and Indian scouts and ordered the rest burned. ${ }^{90}$ The loss of three of his men and serious wounding of six others, including Stock Whitley, far outweighed the meager rewards gleaned from the destruction of the camp and supplies.

Failing to catch the band of Shoshonis that inflicted such a sting on his command, and with orders to press on to Harney Lake and meet Currey, Drake led his men southward for two more weeks. Arriving at Harney Lake before Currey, Drake explored
${ }^{88}$ Drake, 33.
${ }^{89}$ O.R., 50: 1, 346.
${ }^{90}$ Drake, 37 -38. 
the region, both to chart the land and hopefully to flush hostile Shoshonis from their hiding places, while he waited. In late June he sent riders out to find Currey, and as noted the two commands finally merged on July 1.

Merging the two commands was, by no means, the best strategy to follow when trying to chase off or exterminate the highly mobile Shoshonis, who broke into small bands during the summer months. ${ }^{91}$ In Captain Drake’s opinion, merging the two commands was "the very worst thing that could have been done, binding the command down in orders to a course of action that will prove futile to accomplish anything whatever.” The initial orders, granting each command the autonomy to move independently and range broadly appeared the far more logical, but, Drake lamented, “at the eleventh hour an order is received that will destroy the effective strength of both. .. . What a blunder!"92

Time demonstrated the good captain's wisdom when, while the commands were united, little was accomplished, despite the strength and relative mobility of the force. Given the size of the command, finding sufficient water and feed often proved difficult, thus hindering their activities. In fact, it was two weeks before the joint force came into contact with any predatory Shoshonis, and nothing came of that fire-fight because, as Captain William Rinehart recalled, “It soon became apparent that whilst they were firing over us we were under firing them, as our bullets could be seen striking the cliff twenty feet below the hostiles." 93 In the wake of several weeks of inconclusive scouting, Currey ordered the commands split up, both operating from their supply bases, which were only

\footnotetext{
91 Edwards, 98-99.

92 Drake, 25.

93 Rinehart, MSS, 19.
} 
a few miles apart at this point. The commands never reunited, and Currey left for his supply base on August 2, while Drake remained in the Harney Lake area, sending out patrols and short reconnaissance parties. Both commands marched for their respective bases, either Fort Dalles or Walla Walla, in mid September and prepared to set up winter quarters by October. Essentially, nothing had been accomplished by the combining of the two forces, which led a bitter Captain Drake to comment: “Taking all things into consideration Genl. Alvord could not have botched matters worse if he had aimed at it direct." 94

The 1864 campaign season was not exactly a failure, but it was not exactly a success either. By ordering his main field commands to merge into a single large body, Alvord caused them to be plagued with all the complications large numbers faced in that inhospitable land, ultimately hamstringing the effort to find and destroy hostile Indians. The fear that a massed uprising by several bands of Native Americans ignored their tradition of breaking into small bands during the summer months, when sustaining a large community would be difficult in the arid lands. Therefore, Alvord altered the initial strategy based on a false understanding of the situation, forcing the two commands to adjust their movements so they would meet, and then merge, eventually acting as one although only for a month -but by that time the damage had been done.

The reality was that the district commander fell victim to the tendency to apply outdated strategies to changing circumstances. However, the initial activity, even the set backs, and the continued presence of mounted troops in the field did limit, but not halt, Indian depredations in eastern Oregon in 1864. Captain Currey demonstrated a better

94 Drake, 81. 
understanding of the situation than the new department commander when he requested authority to keep his command in the field during the winter at Camp Alvord, situated in the Shoshonis’ wintering grounds. ${ }^{95}$ Department commander, Major General Irvin McDowell, denied the request, missing an opportunity to defeat the much feared and despised Shoshonis. What might have been accomplished is unknown as the 1865 strategy focused on defensive presence, in which the newly formed First Oregon Infantry was parceled out to posts throughout the region, providing safe havens for travelers, but conducting few sweeping expeditions.

In many ways the campaigns in the District of Oregon can be seen as a metaphor for how officials dealt with the Native Americans throughout the expanse of the Department of the Pacific during the Civil War. Confronted with a multiplicity of responsibilities, enhanced by the growing number of immigrants traversing the district, just as they were throughout the entire department, officials at both levels struggled to come up with strategies to deal with the Indian threat while confronting other dangers. Even more so than the years before the war, department commanders faced the dilemma of how to marshal their troops for maximum effect. Of course, the policy followed included distributing troops to posts throughout the department's various districts, and sending patrols from those posts on what essentially amounted to search and destroy missions. Doing so proved far more difficult, administratively, because of the need to protect the Far West from external threats as well as quell any internal unrest initiated by pro Confederates.

${ }^{95}$ Edwards, 118-123. 
Despite these dangers, department officials allocated the bulk of their troops to confront the dangers posed by warring Native Americans. The first departmental returns after the creation of the District of Humbodlt show that 1,100 of the department's 4,800 troops served in the Humboldt and Oregon districts, where the primary concern was defeating the Native Americans. ${ }^{96}$ That distribution is somewhat deceiving because it includes the large contingent of California troops designated for service in the Department of Arizona. More telling are the returns for 1863. At the end of June, 1,900 troops served in the same two districts, with more than 850 in the District of Utah as well. Most of the troops in that district were assigned the task of protecting the immigrant trails and the Overland Mail Route from raiding bands of Native Americans. Thus, the first departmental returns for 1863 show over 2,700 troops stationed in regions almost exclusively concerned with defeating the various Indian tribes, and that number is derived from a total departmental strength of 3,637. By the end of the year there were fewer troops stationed in those districts, but the roughly 1,800 men still represented a significant percentage of the departmental strength of just over 4,000. Furthermore, these numbers do not include those troops in the District of Southern California trying to put an end to the fighting in the Owen's River valley, which would add between 100 and 200 more troops to those whose primary task was confronting Native Americans. ${ }^{97}$

The reality was that despite the increased need to jockey around a larger number of troops over a more expansive territory, the Civil War did not drastically alter how the United States military dealt with the indigenous population in the Far West. In many
${ }^{96}$ O.R., 50:1, 1168.
97 O.R. 50: 2, 505. 711. 
ways, the task of dealing with the Native Americans in the Department of the Pacific during the Civil War, which was just one facet of the department's complicated responsibilities, can be seen as a transitional phase. Prior to the war, before additional gold and land rushes swept the Pacific slope, there simply were too few whites competing for Native American lands to warrant the allocation of troops at the Civil War and post war levels. With the additional rush of people not only seeking better lives but also trying to escape the fighting in embattled states, Department of the Pacific leaders and men found themselves embroiled in more clashes than ever before, many taking place simultaneously throughout the massive department.

Given the increased violence along the immigrant and mining frontiers, Department of the Pacific leaders demonstrated a tenacious, often brutal, ability to quell in some cases, and limit in others, the Indian attacks. When considering the confusion that came with the recall of nearly all the Regulars to the eastern battlefields, and the resulting chaos of replacing the professional soldiers with volunteers, men like Wright, Alvord, McClaughlin, Carelton, and others performed the job of protecting the immigrants sufficiently well so as not to let it retard the migration to the region. By taking aggressive steps to avoid clashes and then crushing them as soon as possible if they could not be averted, the Department of the Pacific provided material assistance to the Union war effort by encouraging people to develop the Far West and all its natural resources during the war -and for the future as well. This feat is especially impressive considering the multiplicity of dangers beyond the often volatile relationships between whites and Native Americans. Even if success in this part of the overall war effort did not gain laurels for the officers and men of the Department of the Pacific, they could be 
justly proud of the contribution to the very complex responsibilities faced by the left arm of the Union. 


\section{CHAPTER}

- 7 -

\section{EORUM BELLUM SERVITIUM}

At noon on July 28, 1865, the overburdened steam ship, Brother Jonathan, prepared to make its usual voyage from San Francisco harbor to Puget Sound. The ship, however, was so laden with goods and passengers that it could not pull itself out of the mud into which the weight had pressed it. Finally, with the rising tide and the help of a tug, the ship left the harbor at 4:00 pm. This was an inauspicious, even foreboding, beginning to an ultimately tragic voyage. George Wright, his wife, and staff, were among those aboard the ill-fated ship. After two days making very slow progress against a storm generated strong head wind, the Brother Jonathan struck a reef off the California coastal town of Crescent City. The ship slid beneath the sea in less than 45 minutes, before most of the groggy and seasick passengers and crew could make it on deck, almost all of whom were asleep when the ship struck the reef. Only one lifeboat, with 19 cold, nearly naked souls aboard, made it through the churning sea in the pre-dawn darkness and eventually reached shore. Six weeks after the tragedy George Wright’s badly decomposed body washed ashore 150 miles from the site of the disaster. General Wright, his wife, and his staff, were among the more than 200 passengers who perished in California’s worst maritime disaster. ${ }^{1}$

\footnotetext{
1 The information about the Brother Jonathan voyage and sinking is drawn from Carl Schlicke, General George Wright: Guardian of the Pacific Coast (Norman, OK: Oklahoma University Press, 1988), 330-335.
} 
Even though he had not commanded the Department of the Pacific for a year, in many ways George Wright's death signified the end of the department's Civil War service. After all, he led the department longer than the other three commanders combined and therefore faced the majority of the department's myriad of wartime responsibilities - and deserved the greatest share of the credit for most of its successes. Therefore, in a post war era in which so many books and articles were written (and speeches given) about the war, his death greatly reduced the likelihood that the volunteers who protected the Pacific Slope would ever receive fair recognition for their long, complicated, and arduous service to the nation. As time passed, only a small handful of volunteers stepped forward to inform the nation about the role they had played in winning the war by protecting the Far West from a plethora of threats. Despite the general lack of awareness about their service, the veterans, as one of them said years later, could take comfort in "the proud consolation of saving this Western Empire of broad and prolific acres and its mighty mountains, the source of the mineral wealth of our great American republic." ${ }^{2}$ The old soldier was correct, when considering what was asked of the Department of the Pacific in light of what they achieved during the war, there is no doubt that with fewer than 20,000 troops the department had successfully protected the left arm of the Republic.

From the outset of the war, the Department of the Pacific’s most important responsibility was maintaining Union control over the Far West. Doing so meant more than preventing the region from falling into Confederate hands. This multilayered task

${ }^{2}$ Hugh Gorley, “The Loyal Californians of 1861,” in Civil War Papers, California and Oregon Commandery of the Military Order of the Loyal Legion of the United States, 60, (Wilmington, North Carolina, Broadfoot Publishing, 1995), 202. 
also meant preventing local secessionists from disrupting the region’s economic and political routine, or letting the vast wealth be exploited to aid the Confederacy. The key to thwarting any such designs was juggling the department's strained resources to meet one threat while not weakening another part of the command. This placing of troops in the right place at the proper time to address its many simultaneous needs was the fundamental challenge the Department of the Pacific faced throughout the war.

At its peak, the department's present for duty strength never exceeded 5,500, and that total was for June 30, 1865, two months after the bulk of the Confederate forces surrendered. ${ }^{3}$ The Department of the Pacific’s highest strength level occurred on December 31, 1864, when the tallied fell just short of 4,300 troops. ${ }^{4}$ Although both totals are larger than the pre war allotment, these were paltry numbers of troops, given the increased responsibilities during the Civil War. ${ }^{5}$ Never-the-less, deft handling of the department's manpower resources enabled the succession of commanders to meet the government's primary goal of maintaining control of the region without outside assistance.

In late 1861, while the Union government reeled from serious defeats in Virginia and Missouri, the Department of the Pacific's preparedness was put to the test. As Confederate troops took control of New Mexico Territory, gobbling up Union-held forts, the department scrambled to meet the oncoming storm. Although a combination of

3 War of the Rebellion: Official Records of the Union and Confederate Armies, (Washington D.C.: Government Printing Office, 1897), 50, 2, 1272.

${ }^{4}$ Ibid, 1109.

${ }^{5}$ O.R., 50:1, 428. The return for December 31, 1860 gives the number of present for duty at just under 2,400, at that time divided up into the Departments of Oregon and California, which were shortly merged back into the Department of the Pacific. 
Regulars and Colorado and New Mexico volunteers halted the Confederate advance in early 1862, Department of Pacific forces chased off the remaining bands of Confederates and pressed on so aggressively that they eventually advanced into western Texas. In the process they fought (and lost) the western most "battle" of the war, roughly 70 miles from the California border. The presence of California troops in New Mexico Territory (encompassing the present states of New Mexico and Arizona), and Texas, and stationed on the New Mexico Territory - California border ensured that there would not be any serious Confederate threat coming from the east during the rest of the war. Thus, even though department troops did not halt the main body of Confederates, during the ill-fated drive toward California, their presence in the scorching southwestern deserts ended Confederate hopes attempting a later of invasion of California.

The permanent Confederate retreat made another of the department's responsibilities easier. Not only had the Department of the Pacific thwarted all efforts and plans to either take the Pacific slope out of the Union or to exploit its wealth for the Confederate cause, it was also charged with defusing potentially dangerous schemes by secessionist, and impeding the flight of those Confederate sympathizers trying to reach the main theatre of war. By keeping Confederate forces at bay far to the east in Texas, the western volunteers made it more difficult for far western secessionists to join the southern armies. Of course their patrolling in some of the most inhospitable places in the country, combined with well-manned Fort Yuma, left most regional secessionists unable to leave the department boundaries. Certainly, some determined southern sympathizers did get through, but overall the effective distribution of troops resulted in few secessionists leaving the Far West, as well as netting a number of notable captives. 
Perhaps the most notorious of those captured was former state assemblyman Daniel Showalter and his party of 18 would-be Confederates, which one Union officer described as "a desperate set of men.” ${ }^{\circ}$ The Showalter party planned to edge past Fort Yuma on the Gila/Colorado rivers and then set out across the Arizona desert on its way to Texas. Instead of joining the Confederate forces in 1861, the various members of the party spent less than six months incarcerated at Fort Yuma before being released in early 1862. ${ }^{7}$ Quite a few secessionists found themselves prisoners at the fort, where escape was all but impossible and where it was unlikely there would be any meddling from civilian authorities concerned about rights violations. After the first few, chaotic, months of the war, escaping the Department of the Pacific's grasp proved too challenging for most southern sympathizers and the frequency of such desperate endeavors dropped off.

Just how much assistance a stream of western secessionists might have provided the perpetually under-manned Confederate armies is unclear. However, a number of southern schemers believed there was a large source of potential Confederates in California alone. ${ }^{8}$ Ultimately, the Department of the Pacific's ability to first thwart and then discourage western secessionists from trying to flee to the South meant whatever manpower pool might exist in that part of the Far West would not join the Confederate armies.

Just as important as keeping Confederate forces from invading the department or large numbers of secessionists from fleeing was protecting the region from internal

${ }^{6}$ Ibid, 33.

${ }^{7}$ Clarence Clendenen, "Dan Showalter -A California Secessionist," California Historical Quarterly, 40 (1961) 4, 318.

${ }^{8}$ Ibid, 321-322. General Sumner warned that there were 20,000 secessionists in the state, ready to aid any Confederate effort to wrestle control of the region from the Union. O.R., 50: 1, 610. 
unrest. Success in this regard seemed somewhat in doubt at the outset of the war, however, by war's end the department could boast that not one plot to wrestle the Far West from Union control had succeeded. This, in turn, meant that the incredibly important gold shipments and regional harbors remained safe throughout the war.

By concentrating forces at danger spots, such as Los Angeles, San Bernardino, and Visalia in southern California, and southwest Oregon, department commanders demonstrated the importance of a strong working relationships between the military, naval commanders, and civilians. The best example of this successful cooperation occurred during the 1863 capture of the Chapman in San Francisco harbor. It was a joint effort between the civilian, naval, and military authorities that foiled the attempt to capture the Chapman (for the purpose of raiding the gold shipments). Such incidents as the attempt to seize the Chapman, as well as the stagecoach robbery near Placerville, California in June 1864 were, however, were the exception and not the rule when it came to how the department dealt with the secessionists.

Throughout the war, the timely arrival of Union forces at the troubled spots kept the Confederate sympathizing element in check. For making that possible, the department deserves a great deal of credit for employing a network of spies that put the generally inept Pinkerton agents used in the East to shame. Remaining well informed about the attitudes of the local populace throughout the department led officials to remove warehouses of arms and munitions from endangered places, as they did in Carson City, Nevada, thereby further discouraging any secessionist plots. The general lack of anything more than occasional displays of either the Confederate battle flag or the Bear flag, attest to the department's success in protecting the Far West from internal threats. 
Had the Department of the Pacific failed in this endeavor, it is still unlikely the secessionist element could have seized control of the entire region. However, had any such effort succeeded, particularly in the war's early days, a situation akin to that which existed in Kansas might have erupted in the Far West, requiring Union troops be sent to the region to reestablish federal control.

Protecting the northern and southern borders, at a time when uneasy relations existed between the United States and both Mexico and Great Britain, also required cooperation between civilian and military leaders. Had it not been for that cooperation there was a distinct danger north of the border and a threat from Mexican republicans and French imperialists both below and within the department's borders. In its effort to protect the Far West from any dangers emanating from the British Columbia or Vancouver Island colonies, whether that danger originated from British military forces or secessionists then in either colony, the department received invaluable aid from the American consul in Victoria, British Columbia, Allan Francis. Through Francis' use of informers and spies, he enabled the department commanders to remain abreast of all pro Confederacy plots developed on Vancouver Island during the war and discourage those efforts through diplomatic means as well as the timely (if brief) display of the American naval presence.

Although the British officials in western Canada could not act without permission from London, it is important to remember that relations between the United States and Great Britain were strained, particularly in the wake of the seizure of Confederate agents from the British ship Trent in November 1861. Furthermore, the royal governor in Victoria went so far as to suggest to his superiors that the best defense against anticipated 
American aggression in the region was to invade first. ${ }^{9}$ In this atmosphere, it was the good communication between the American consul and the British officials as well as the calm and restraint shown by Department of the Pacific commanders, who knew there was a vocal secessionist segment within the Canadian population, that prevented an eruption along the northern border.

By working together, department commanders sifted the information passed onto them by consul Francis, then put their troops on the alert, and, when necessary, called up on the Pacific Squadron for naval assistance. The hard-pressed navy did the best it could with even more limited resources than its land-locked counterpart. When department leaders sought to enhance American visibility in Puget Sound, the navy could only send an additional ship -and only for a limited time. Those actions, however, combined with the presence of a number of military forts and camps along Puget Sound or along the interior border sufficed to protect the northern border.

The Department of the Pacific faced an entirely different situation along the Mexican border, where the chaos that reigned within that nation's borders was the greater danger than any designs the Mexican government might have on trying to recapture its lost lands. The absence of any such idea did not eliminate the threat to regional stability. The problem confronting the department, regarding relations along its southern border, was far more dangerous and challenging than it was along the northern border.

Again, department leaders showed tremendous restraint, both personal and professional, in their handling of the volatile situation that churned out of Mexico almost from the outset of the Civil War. By 1863, with the duly elected Mexican government on

${ }^{9}$ Robin Wink, Canada and the United States The Civil War Years, (Baltimore: The Johns Hopkins Press, 1960), 158. 
the run, and officially deposed by the French imperial puppet regime of Maximilian, the state of California became the scene of a cold war. San Francisco, in fact, was the epicenter of an espionage war carried out between agents of the Juarez regime and French operatives. With troops in place along the department's southern border, sent there initially to protect against a Confederate invasion as well as to capture secessionists trying to escape to the South, department officials had to navigate the difficult path between their own personal support for the Mexican republicans, which mirrored the general populace’s support for the Juarez government, and national policy. Had any of the department commanders, or their subordinates, failed to maintain that very precarious position, it is likely that the United States would have been pulled into the destructive vortex in Mexico.

Despite their own feelings, which the Union commander, U.S. Grant, shared, and the general public's support for the Mexican republicans, national policy required strict neutrality. This position favored the French puppet regime, whose agents used the American policy to force department officials into blocking both the removal of weapons to Mexico and the departure of American Juarez supporters. Although strict neutrality meant having no choice but to confiscate weapons caches and turning back Juarez reinforcements none of the department leaders carried out those orders with any alacrity. Wright and McDowell, especially, did little to disrupt Mexican efforts to acquire arms and men, unless cornered into action by the French consul, who used agents and bribed American officials to unearth shipments and recruitment efforts.

The French succeeded in manipulating department officials into acting on Maximilian's behalf, which meant they followed the neutrality as required. However, so 
many officers turned a blind eye or moved so ponderously when ordered to confiscate arms shipments or apprehend Americans heading to Mexico (ostensibly part of a fictitious prospecting endeavor named the Arizona Exploring Expedition), that enforcement was often ineffective. In essence, Department of the Pacific officials found a way to keep the Far West from being drawn into the civil/imperial war going on south of the border, while at the same time not completely abandoning their personal sympathies for their sister republic.

While many officers and troops sympathized with the elected Mexican government, and thereby courted danger by letting their personal sympathies seep into their (in)actions, they showed virtually no sympathy when dealing with the region's Native American tribes. Erratic relations between the growing, and spreading, white population and the regional tribes plagued western military leaders long before the Americans arrived, and it continued well after the Civil War. Dealing with the Indian "question" for some or "problem" to others proved more challenging during the war years. Fortunately for emigrants traversing the various trails leading to the Far West, and miners, and farmers already there, the department's first leaders were experienced, sometimes ruthless, when dealing with the far western tribes. Given this level of command experience, it was not surprising that the Department of Pacific compiled a string of victories over the tribesmen, some by military force and some through negotiation.

With the exception of putting far more troops in the field to confront the warring tribes, little changed about the nature of the military relations between the department and the various tribes. In a sense, this was beneficial because long-serving commander, 
George Wright, successfully, and brutally, dealt with various Pacific Northwest tribes during the 1850s. Prior to Wright's assumption of command, Albert Sidney Johnston and then Edwin Sumner endured months of trying to calm politicians and citizens throughout the region. Each local official demanded something be done to prevent Indian depredations, acting as if theirs was the only part of the department in jeopardy, and of course, never admitting the role played by white antagonism in the increasingly violent atmosphere.

Although Johnston was an experienced Indian fighter, and solid soldier, and Sumner a hard fighter in his own right, nervous far westerners benefited greatly when Wright assumed command of the department in September 1861. Under Wright a new military district was created along California's north-west border specifically to deal with the increasing problems between Native Americans and the expanding numbers of white farmers. The influx of farmers into the Humboldt district, as it was termed, began before the start of the Civil War, but during the war years the friction caused by the competition for land led to increasing violence. Therefore, in an effort to make the region safe for development by whites, General Wright not only created the new military district, he also committed a large number of troops to the task.

This scenario repeated itself in California's southeastern corner, in the Owen's River valley. There, too, reinforced forts and numerous mounted expeditions helped to quell the uprisings. After two concerted campaigns in 1862 and 1863, violence in the valley came to an end once the surviving tribesmen were removed from their homelands. The military performed the task of subjugating the local Native Americans with a bloody precision that, on a small scale, at least matched the work other soldiers did in the 
Humboldt district. ${ }^{10}$ After years of fighting and many deaths, department troops had forced the tribes to give up their lands, thus enabling white farmers to exploit the rich lands, just as Wright intended and the citizens wanted.

The Department of the Pacific faced a different challenge when trying to protect the emigrants streaming into its expansive borders. With more troops available than before the war, one would think protecting the emigrant trains would have been easier although not easy. However, the influx of people increased well beyond the proportional expansion of the department's manpower levels. The key was to prevent another Van Orman catastrophe, where all but 15 members of a wagon train were killed by roving Mountain Bannocks near Salmon Falls (present-day Idaho) in September $1860 .{ }^{11}$

Department officials did their best not only by strengthening those posts along the trails, but by creating new forts and camps. The establishment of such forts as Boise and to a lesser degree Lapwai, put troops nearer the endangered network of trails, and thus provided emigrants with additional protection. Doing so, combined with aggressive patrolling, particularly in Oregon and Idaho Territory, paid off. Although small bands of Bannock Indians did attack small trains or other isolated groups during the war, the likelihood of an attack diminished from pre-war levels. That success encouraged more emigrants to head westward, looking for opportunities, and in the process they developed the region, just as politicians, and many military men, wanted. Those patrols across the

${ }^{10}$ For the handling of the Owen's River campaigns see, O. R.., 50: (1 and 2), particularly 50, 1 145-153, 210-213.

${ }^{11}$ For an account of the Van Orman or Salmon Falls Massacre, see Carl Schlicke, "Massacre on the Oregon Trail in the Year 1860," Columbia, 1 (1987) 1, 33-43. 
dusty high plains deserts and over mountain ranges might have been forgotten, but they played an integral part in the development of the West during the Civil War years.

The department's efforts battling tribes, whether the various Bannock Indians along the northern emigrant trails, or the tribes in the Owen's River Valley and those in the Humboldt district, did help open the Far West to white development. However, Indian wars were costly, both in lives lost and in time consumed before it was safe enough that emigranting farmers were willing to risk their lives establishing farmsteads. Fortunately, George Wright was well acquainted with the most powerful tribe within the department's borders, the Nez Perce, who controlled vast lands in what is now Oregon and Idaho. The Nez Perce's legendary tolerance was put to the test when gold was discovered on those lands. That the various bands did not wipe out the miners is a testament both to their incredible patience and the effective negotiating skills of department officers like Brigadier General Benjamin Alvord, who commanded the District of Oregon. Even Alvord, who spent many years in the Pacific Northwest, could not believe the reserve shown by the Nez Perce. He told Oregon senator, James Nesmith "It is a miracle considering the mass of people upon their reservation that last year or two, that last month the first alleged murders by Indians occurred." ${ }^{\prime 2}$ In early 1863, with more and more whites scrambling over lands guaranteed the Nez Perce by an 1855 treaty, Wright and Alvord knew something must be done to avoid a confrontation -one that might last a long time. ${ }^{13}$ Fortunately for the miners, and the increasing number of

${ }^{12}$ Alvord to Nesmith, November 25, 1862, cited in Alvin M. Josephy, The Nez Perce Indians and the Opening of the Northwest, (Boston and New York: Houghton Mifflin Company, 1997), 413.

${ }^{13}$ It is important to note that the situation in 1863 favored the Nez Perce more so than it did in 1877 when war with the tribe finally did break out. By then the white population was larger, the military had fewer responsibilities, and the government was able to put more energy into the development of the 
farmers that were also heading into the Nez Perces' fertile Wallowa Valley, negotiations proved successful, although not conclusive, and a war with the most powerful tribe on the West Coast was avoided - or at least postponed for 14 years. ${ }^{14}$

The Department of the Pacific, with more men than the military had at its disposal prior to the war, opened vast lands for white exploitation, both for farmers and miners, and it protected the immigrants traveling to those lands, as best as possible. Just as was the case with all of its other responsibilities, the department's success in opening far western lands materially aided the development not only of the West, but the economic growth of the nation. The process of opening Native American lands, however, had not been easy and the eruption of conflicts meant the overall objective of maintaining peace in the region periodically failed. However, quelling the unrest never required the assistance of outside forces, soldiers desperately needed for carrying out the war in the East. Compared to departmental efforts to protect the region from external Confederate forces and internal secessionists, while guarding the borders, dealings with the various tribes throughout the vast Department of the Pacific was far more problematic, yet the outcome was just as successful.

Throughout the war, the Department of the Pacific successfully met a myriad of challenges, and in the process protected the Far West from both internal and external threats, organized by foreign and domestic forces. While the war created many new responsibilities for the most remote military department, it also simultaneously made the

West (instead of fighting the Civil War). Had department officials been unsuccessful, the results would have been much bloodier than they were 14 years later, went the deck was stacked against the Nez Perce.

${ }^{14}$ Ibid, 415-429 the 1863 treaty, with all of its intrigue, political gamesmanship, and weakness, is treated in depth in this section of Josephy's excellent study. 
traditional tasks even more complicated than prior years. By preventing the region from falling under Confederate, or regional secessionist control, protecting both the northern and southern borders from foreign intrusion, while using force to control the Native American population -without drawing troops from the main theatres of war - the Department of the Pacific played an important, and generally overlooked, role in the Union victory. Its success meant raw material (primarily ore) continued to flow from the Far West, boosting the Union economy, while wagons streamed into the department's vast lands.

Ultimately, the war was about establishing a new version of the Union, which not only meant a South without slavery, but also an increasingly important West. Through their sacrifices, deaths, and arduous service, Department of the Pacific veterans could rightly claim to have done their share by protecting the left arm of the republic. Major DeWitt Thompson, who led one of the two groups of Californians that fought in the East, extolled the virtue of those volunteers who remained on the Pacific Slope when he said, “They guarded the country from British Columbia to Mexico, from the shores of the Pacific to the Rocky Mountains -an empire in extent. They fought the stalwart aborigines in the north and the treacherous Apaches of the south.”15 Although they knew their service was in the shadow of the great and bloody struggle in the East, they spoke about their achievements with a certain laconic pride, believing what few others cared to acknowledge. As one veteran wrote on the last page of his diary, "By losing their lives [they] gave freedom to thousands of travelers who seek new homes amid the western

${ }^{15}$ MOLLUS, 60, 136. 
wilderness.” ${ }^{\circledR 16}$ Without any fanfare, and since largely forgotten, the Department of the Pacific guarded the Far West for the Union, secured its borders, and defeated the various tribes who chose to defend their lands, and in so doing they contributed to the Union cause and laid the groundwork for the rapid development of the Far West.

${ }^{16}$ Hiram Tuttle, cited in Aurora Hunt, Army of the Pacific, 1860-1866 (Mechanicsburg, PA: Stackpole Books, 2004), 364. 


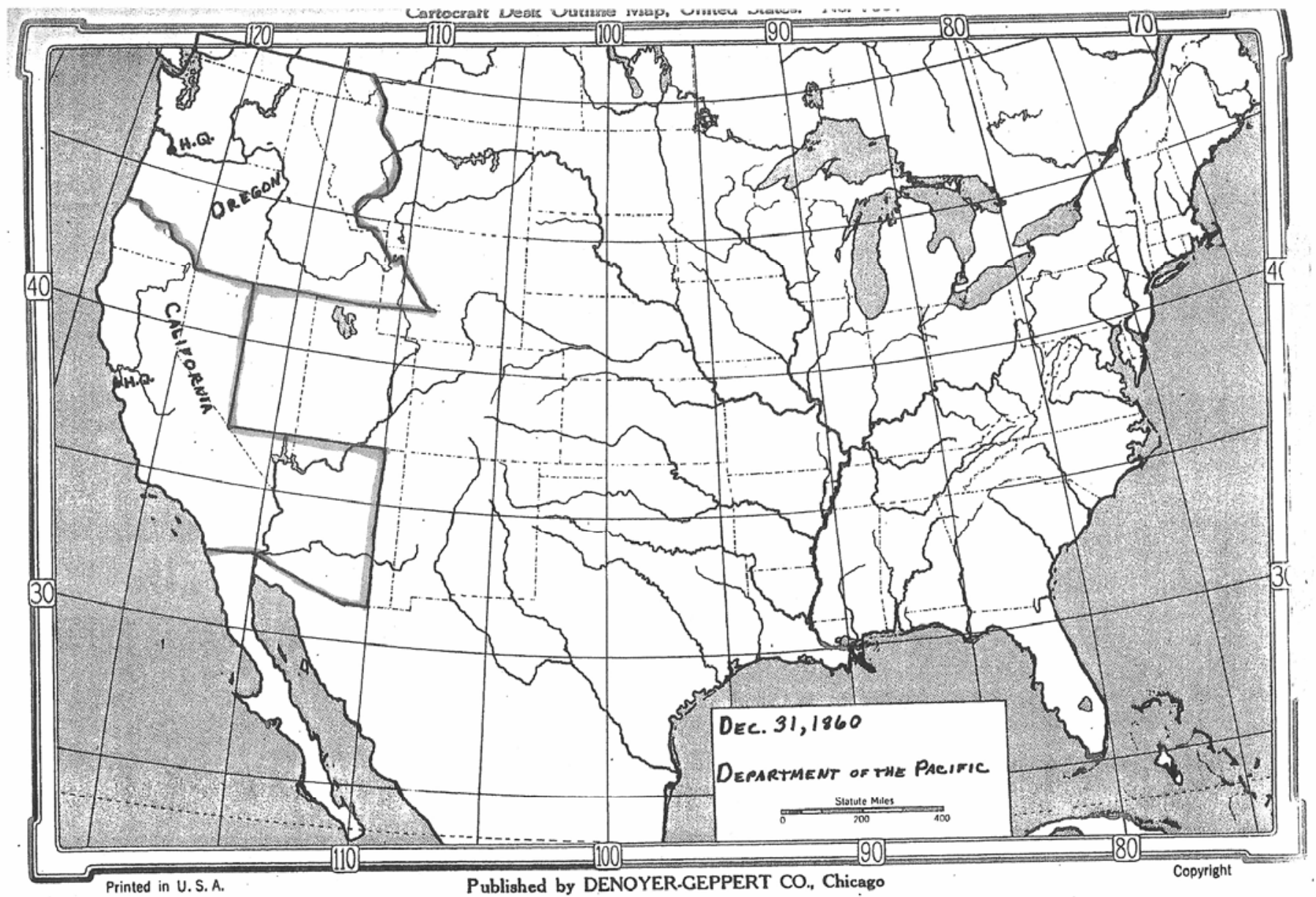

Original Map in Lloyd Wayne Herbener, “The Military Establishment in Southern California During the Civil War,” (Mater’s thesis, Claremont Graduate School, 1952), Table 1, plate 1. 


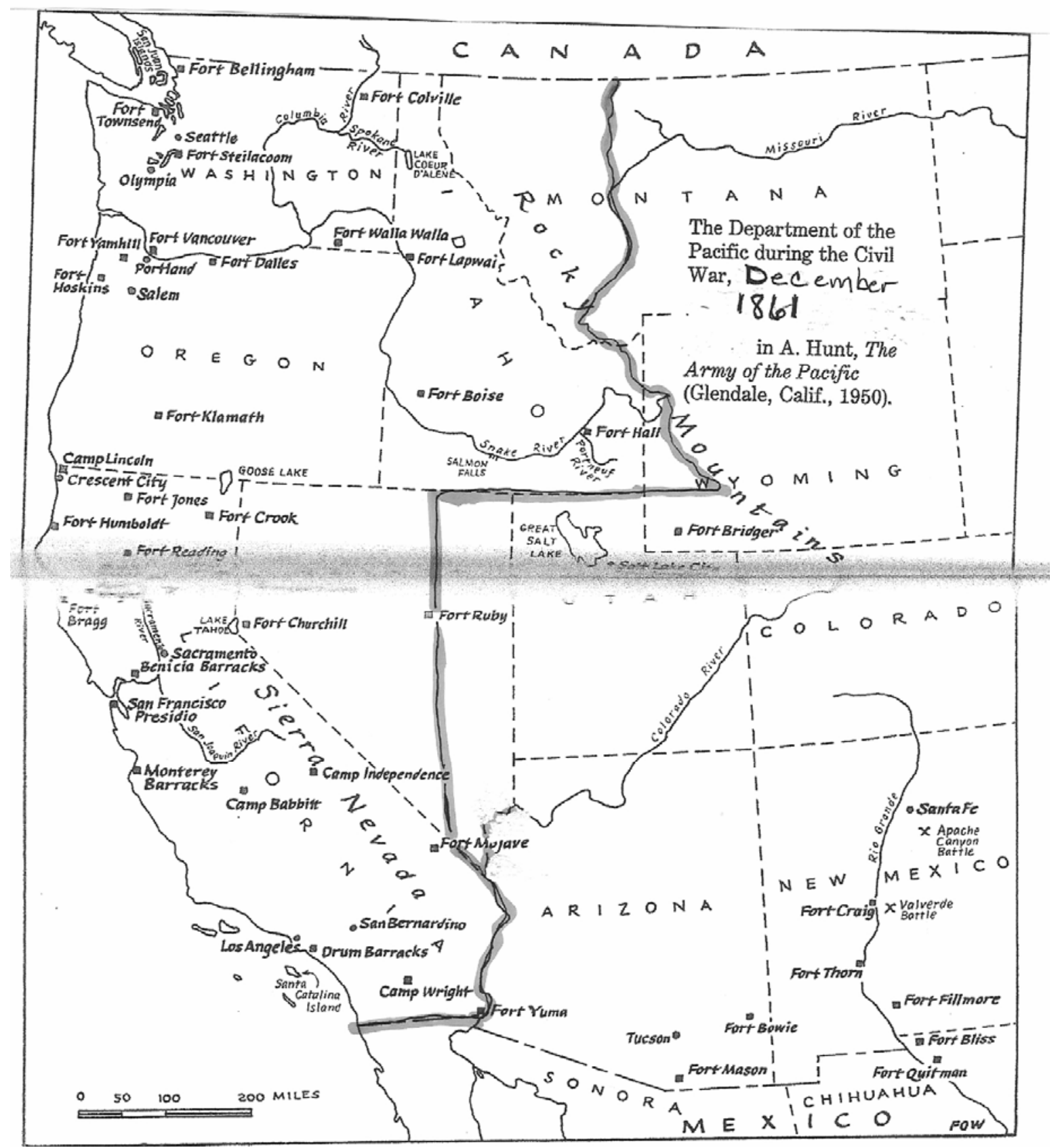

Original map in Aurora Hunt, Army of the Pacific (Glendale, CA: Arthur H. Clark, Co. , 1950), front inset. The departmental boundaries, as determined by Lloyd Wayne Herbener, have been added. Herbener, plate 4. 


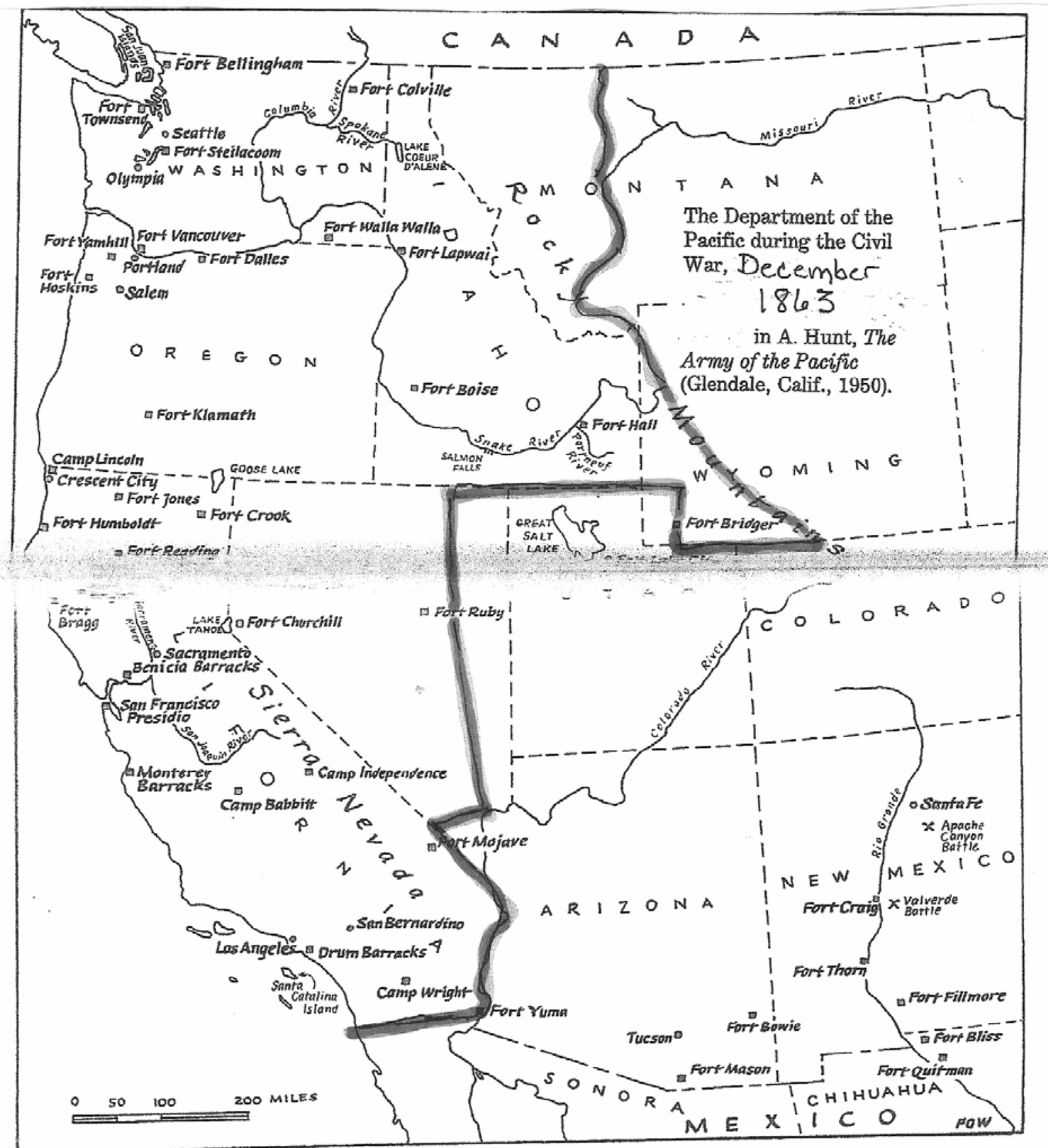

Original map in Aurora Hunt, Army of the Pacific (Glendale, CA: Arthur H. Clark, Co. , 1950), front inset. The departmental boundaries, as determined by Lloyd Wayne Herbener, have been added. Herbener, plate 6 . 


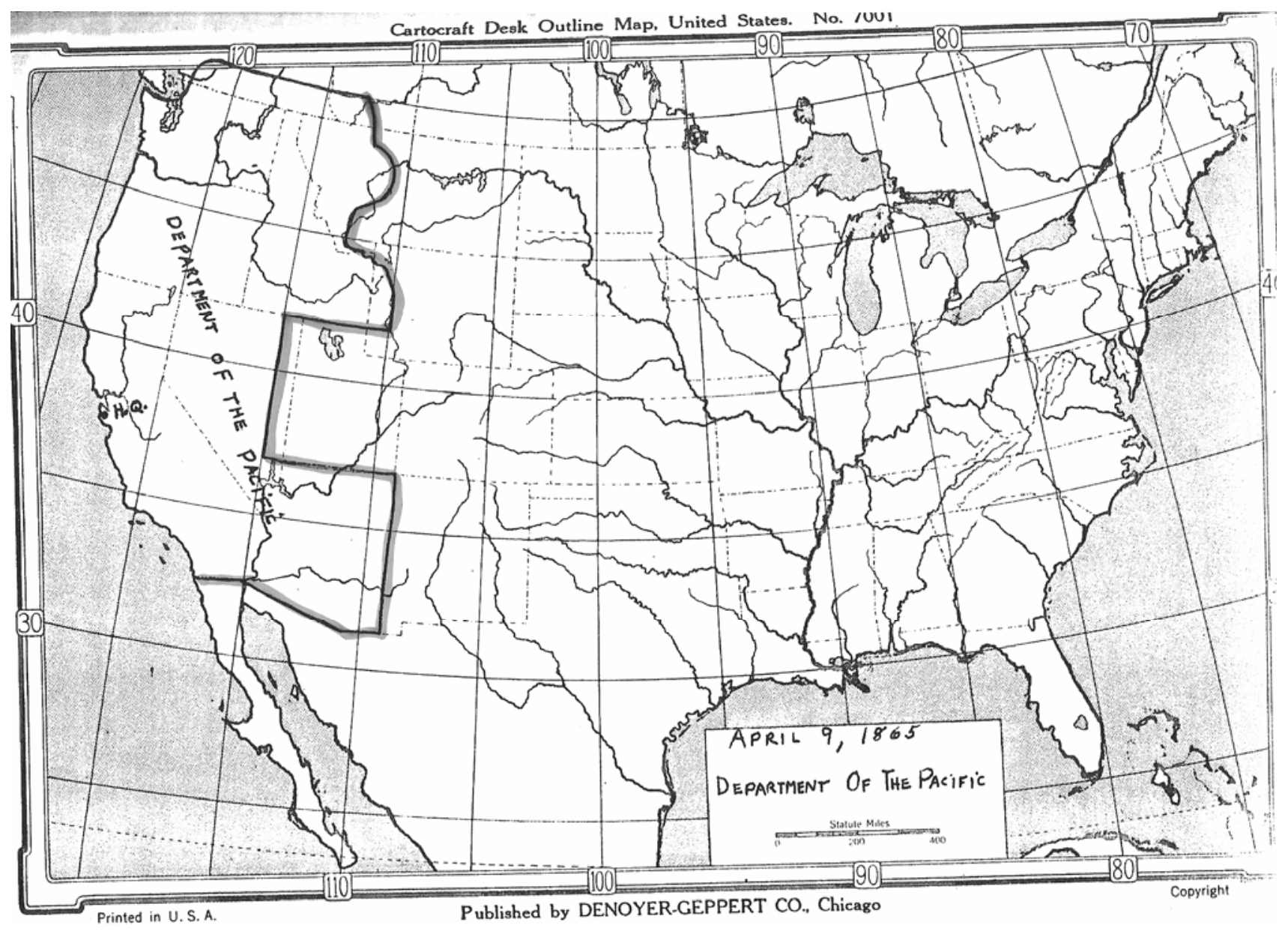

Original map in Lloyd Wayne Herbener, “The Military Establishment in Southern California,” (Master's thesis, Claremont Graduate School, 1952), plate 7. 


\section{BIBLIOGRPAHY}

\section{PRIMARY SOURCES}

\section{UNPUBLISHED MATERIAL}

Bowie, George. “Biographical Sketch of George Bowie.” MSS, H. H. Bancroft

Collection, University of California at Berkley, Berkley, California.

Brown, John Henry. "The Autobiography of John Henry Brown.” MSS. H. H. Bancroft Collection, University of California at Berkley, Berkley, California.

Cooper, Arvanzona A. “Recollections.” MSS, Oregon Historical Society, Portland, Oregon.

Crawford, Medorem. Papers. Oregon Historical Society, Portland, Oregon.

Dandy, George B. “Dandy’s Reminiscences.” MSS, Special Collections, Holland Library, Washington State University, Pullman, Washington.

Drake, John M. Papers and Correspondence. Maury-Drake Collection, Oregon Historical Society, Portland, Oregon.

Graffnell, Charles S. Papers. United States Military History Institute, Carlisle Barracks, Pennsylvania.

Jones, Daniel H. Papers. Oregon Historical Society, Portland, Oregon.

McCleave, William. “Our Scout to Black Canyon,” MSS, William McCleave Papers, Bancroft Library, University of California at Berkley, Berkley, California.

. “Recollections of a California Volunteer,” MSS, William McCleave Papers, Bancroft Library, University of California at Berkley, Berkley, California.

Mullany, James. Papers, 1821-1900. Oregon Historical Society, Portland, Oregon.

Nesmith, James W. Correspondence. Oregon Historical Society, Portland, Oregon.

Reimers, Henry. "Sergeant Ball Left Colorful Through (sic) Fragmentary History." MSS, Cylon S. Kingston Papers. Special Collections, John F. Kennedy Library, Eastern Washington University, Cheney, Washington.

Rinehart, W.V. “With the Oregon Volunteers 1862-6.” MSS, Oregon Historical Society, Portland, Oregon. 
Shelley, James M. "Military Reminiscences of James M. Shelley.” MSS, Oregon Historical Society, Portland, Oregon.

Shelton, John. Papers. Oregon Historical Society, Portland, Oregon.

Smith, John E. “Pioneer Reminiscences.” MSS, Northwest Room, Spokane Public Library, Spokane, Washington.

Taylor, G. Hobart. Diary, Jan. 1 - May 30, 1862. Cushing Memorial Library, Texas A and M University, College Station, Texas.

Thom Family. Papers. Virginia Historical Society, Richmond, Virginia.

Underwood, Amos. "Reminiscences of the Cayuse War." MSS, Oregon Historical Society, Portland, Oregon.

Wood, T.A. “Biographical Notes.” MSS, Oregon Historical Society, Portland, Oregon.

Young, George E. “Journal of Company G, $2^{\text {nd }}$ Infantry California Volunteers.” Microfilm copy in Bancroft Library, University of California Berkley, original in Del Norte County [California] Historical Society.

\section{NEWSPAPERS}

Lewiston, Idaho Morning Tribune

San Francisco, Daily Alta California.

New York, New York, Times.

New York, New York, Army and Navy Journal.

\section{PUBLISHED SOURCES}

Abbott, Helen Betsy, editor. “Life on the Lower Columbia, 1853-1866,” Oregon Historical Quarterly, 83 (1982) 3, 248-287.

Anonymous. An Authentic Exposition of the "K.G.C." "Knights of the Golden Circle:" or A History of Secession from 1834 to 1861. Indianapolis, IN: C.O. Perrine Publisher, 1861.

. “Army Officer’s Report on Indian War and Treaties,” Washington Historical Quarterly, 19, (April 1928) 2, 134-141.

. “Clearwater Gold Rush,” Idaho Yesterdays, 4 (1960), 12-15; 18-26. 
Ayers, James J. Gold and Sunshine: Reminiscences of Early California. Boston: The Gordham Press, 1922.

Backus, Samuel W. "Californians in the Field: Historical Sketch of the Organization and Services of the California "Hundred” and "Battalion,” $2^{\text {nd }}$ Massachusetts Cavalry," Military Order of the Loyal Legion of the United States, Civil War Papers of the California Commandery and Oregon Commandery. Wilmington, N.C.: Broadfoot Publishing, 1995.

Badger, Alexander Caldwell, Jr. "All in Fact . . . Agree With Me” Letters from Fort Vancouver,” edited by Dennis R. Defa, Idaho Yesterdays, 41 (1997) 2, 10-21.

Barnes, Demas. From the Atlantic to the Pacific, Overland. New York: D. Van Nostrand, 1866.

Beall, Thomas B. “Pioneer Reminiscences,” Washington Historical Quarterly, 8 (April 1917) 2, 83-90.

Bender, Flora Isabelle. "Memoranda of a Journey Across the Plains,” Nevada Historical Society Quarterly, 1 (July 1958) 4, 145-173.

Bennett, Robert A. compiler. A Small World of Our Own: Authentic Pioneer Stories of the Pacific Northwest from the Old Settlers Contest of 1892. Walla Walla, WA: Pioneer Press Books, 1985.

Bensell, Royal A. All Quiet on the Yamhill: The Civil War in Oregon. Edited by Gunter Barth. Eugene, OR: University of Oregon Books, 1959.

Blaine, James G. Twenty Years in Congress, two volumes. Norwich, CT: The Henry Bill Publishing Company, 1884.

Blasio, Jose Luis. Maximilian Emperor of Mexico: Memoirs of His Private Secretary, edited and translated by Robert Hammond Murray. New Haven, CT: Yale University Press, 1934.

Bowie, George. Address Delivered Before the Society of California Volunteers. San Francisco: Edward Bosqui and Co., Printers, 1867.

Brewer, William H. Up and Down California in 1860-1864, edited by Francis P. Farquhar. Berkley, CA and Los Angeles: University of California Press, 1966.

Brooks, Justus. The Benevolent Raid of General Lew Wallace: How Mexico was saved in 1864, compiled by Amherst W. Barber. Washington, D.C.: R. Beresford, Printer, 1914. 
Browne, Lina Fergusson. J. Ross Browne: His Letters, Journals, and Writings. Albuquerque, NM: University of New Mexico Press, 1969.

Burgunder, Ben. "Recollections of the Inland Empire,” edited by J. Orin Oliphant, Washington Historical Quarterly, 17 (July 1926) 3, 190-210.

Burnett, Peter H. An Old California Pioneer. Oakland, CA: Biobooks, 1946.

Carlson, Edward. “The Martial Experiences of the California Volunteers,” The Overland Monthly, 7 (May 1886), 480-496.

Carmony, Neil B., editor. The Civil War in Apacheland: Sergeant George Hand's Diary, California, Arizona, West Texas, New Mexico, 1861-1864. Silver City, NM: High-Lonesome Book, 1996.

Clark, William S. "Pioneer Experiences in Walla Walla,” Washington Historical Quarterly, 24 (January 1933) 1, 9-24.

Clark, Walter Van Tilburg, editor. The Journals of Alfred Doten, 1849-1903, three volumes. Reno, NV: University of Nevada Press, 1973.

Commagere, Frank Y. “The Regular Army in 1861,” Philadelphia Weekly Times, August 2, 1884.

Coonc, Elizabeth Ann. "Reminiscences of a Pioneer Woman,” Washington Historical Quarterly, 8 (January 1917) 1, 14-21.

Coulter, C. Brewster, editor. The Pig War and Other Experiences of William Peck: Soldier 1858 - 1862. Medford, OR: Webb Research Group, 1993.

Crofut, W.A., (editor). Fifty Years in Camp and Field: Diary of Major General Ethan Allen Hitchcock, U.S.A., New York: The Knickerbocker Press, 1909.

Cronin, Gerald. “California in the War,” National Tribune, June 5, 1924.

Crosby, Elisha Oscar. Memoirs of Elisha Oscar Crosby. San Marino, CA: The Huntington Library, 1945.

Davis, Hugh H. “Three Letters of William Gird, 'Veteran of Turf, Field, and Farm,'” Oregon Historical Quarterly, 68 (June 1967) 2, 141-152.

Davenport, T.W. "Recollections of an Indian Agent,” Oregon Historical Quarterly, 8 (March 1907) 1, 1-50.

Deamon, B.M. "Perilous Situation of Troops in the Far West When Gen. Twiggs Surrendered,” National Tribune, January 7, 1915. 
Denny, Arthur Armstrong. Pioneer Days on Puget Sound. Fairfield, WA: Ye Galleon Press, 1979.

Drake, John M. “The Oregon Cavalry,” Oregon Historical Society Quarterly, 65, (1964) 4, 392-400.

. “Cavalry in the Indian Country, 1864,” edited by Priscilla Knuth. Oregon Historical Quarterly, 65 (1964) 1, 4-119.

Drew, C.S. Official Report of the Owyhee Reconnaissance. Jacksonville, OR: Oregon Sentinel Printing Office, 1864.

Dunnington, William P. “In the Mormon Country,” National Tribune, December 3, 1896.

Frost, Robert. “Fraser River Gold Rush Adventures,” Washington Historical Quarterly, 22 (July 1931) 3, 203-210.

Gibbs, Addison. “Oregon Grapeshot,” Oregon Historical Quarterly, 65 (1964) 3, 296.

Gibbs, George. "Beginnings of Militia in Washington,” Washington Historical Quarterly, 11 (July 1920) 3, 202.

Gilliss, Julia. So Far from Home: An Army Bride on the Western Frontier, 1865-1869, edited by Priscilla Knuth. Portland, OR: Oregon Historical Society Press, 1993.

Gorley, Hugh. Selections from the Numerous Letters and Patriotic Speeches of My Husband, Mrs. H. A. Gorley, compiler. San Francisco: Bonnard and Daly, 1876.

. “The Loyal Californians of 1861," Military Order of the Loyal Legion of the United States, Civil War Papers of the California Commandery and Oregon

Commandery. Wilmington, N.C.: Broadfoot Publishing, 1995.

Goulder, W.A. Reminiscences: Incidents in the life of a Pioneer in Oregon and Idaho. Boise, ID: Timothy Regan, 1909.

Haller, Granville O. The Dismissal of Major Granville O. Haller of the Regular Army of the United States by Order of the Secretary of War. Paterson, N.J.: Daily Guardian, 1863.

. San Juan and Secession. Seattle: The Shorey Book Store, 1967.

Hamblett, E.T. “Sovereign Americans on San Juan Island,” Washington Historical Quarterly, 1 (1906) 1, 75-77. 
Hayes, Benjamin. Pioneer Notes From the Diaries of Judge Benjamin Hayes, 18491875. New York: Arno Press, 1976.

Henry, A.G. Rogue River War: Speech of Dr. A.G. Henry. Fairfield, WA: Ye Galleon Press, 1995.

Higgins, D.W. The Mystic Spring and Other Tales of Western Life. Toronto: William Briggs, 1904.

Hicks, Urban East. Yakima and Clickitat Indian Wars, 1855 and 1856: Personal Recollections of Capt. U.E. Hicks. Portland, OR: Himes the Printer, 1886.

Hunter, George. Reminiscences of an Old Timer. San Francisco: H.S. Crocker and Company, 1887.

Jewell, James Robbins, editor. “Dear Mrs. Wilmer:” Trooper J.J. Rohn Describes the Steptoe Battlefield,” Military History of the West, 32 (2002) 2, 71-77.

Johannsen, Robert W., editor. “A Breckinridge Democrat on the Secession Crisis:

Letters of Isaac I. Stevens, 1860-61,” Oregon Historical Quarterly, 55 (1954) 4, 283-310.

Johnson, Hervey. Tending the Talking Wire: A Buck Soldier's View of Indian Country, 1863-1866. Edited by Unrau, William E. Salt Lake City, UT: University of Utah Press, 1990.

Judson, Phoebe Goodell. A Pioneer's Search for An Ideal Home. Lincoln, NE and London: University of Nebraska Press, 1984.

Keyes, Erasmus D. Fifty Years Observation of Men and Events. New York: Charles Scribner's Sons, 1884.

King, W.W. “Pacific Coast Soldiers,” National Tribune, October 21, 1886.

Kittell, Allan, general editor. Bear Bravely On: Letters from Sergeant John Buel Dimick, First Oregon Volunteer Cavalry to Almira Eberhard, 1862-1865. Portland, OR: Lewis and Clark College, 1983.

Kittredge, Frank A., compiler. "Washington Territory in the War Between the States," Washington Historical Quarterly, 2, (October 1907) 1, 33-39.

Kip, Lawrence. Indian War in the Pacific Northwest. Lincoln and London: University of Nebraska Press, 1999.

Kowarch, Edward J, editor. Ten Years on the Pacific Coast By F.X. Blanchet. Fairfiled, WA: Ye Galleon Press, 1982. 
Kuykendall, George B. "Reminiscences of Early Days at the Old Umpqua Academy," Oregon Historical Quarterly, 19 (1918) 1, 34-36.

Larson, James. Sergeant Larson. San Antonio, TX: Southern Literary Institute, 1935.

Lloyd, Alice and Brice, Arthur, editors. “The 1858 Battle of Steptoe Butte,” Pacific Historian, vol. 14 (1970) 3, 31-34.

Lockley, Fred. Conversations with Pioneer Women. Compiled and edited by Mike Helm. n.p.: Oregon Country Library, n.d.

. “Reminiscences of Captain William P. Gray,” Oregon Historical Quarterly, 14 (1914) 4, 321-354.

Lord, Elizabeth. Reminiscences of Eastern Oregon. Portland, OR: The Irwin-Hodson Co., 1903.

MacDonald, Benjamin. “Narrative,” Washington Historical Quarterly, 16 (July 1925) 3, 186-197.

McCall, John Marshall. “The First Oregon Cavalry and the Oregon Central Military Road Survey of 1865,” edited by L.C. Merriam, Jr. Oregon Historical Quarterly, 60, (1959) 1, 89-124.

McDougall, James A. French Interference in Mexico: Speech of Hon. J.A. McDougall, in the Senate of the United States. Baltimore: John Murphy and Company, 1863.

Magruder, John B. “Maximilian in Mexico,” Philadelphia Weekly Times, July 13, 1878.

Marchand, Ernest, editor. New from Fort Craig New Mexico, 1863: Civil War Letters of Andrew Ryan, with the First California Volunteers. Santa Fe, NM: Stagecoach Press, 1966.

Masterson, Gay. One Woman's West. Edited by Lois Barton. Eugene, OR: Spencer Butte Press, 1990.

Merrill, Irving R., editor. Bound for Idaho: The 1864 Trail Journal of Julius Merrill. Moscow, ID: University of Idaho Press, 1988.

Miller, Henry. “Letters from the Upper Columbia,” Idaho Yesterdays, 4 (1960-61), 1422.

Moak, Sim. The Last of the Mill Creeks and Early Life in Northern California. Chico, CA, 1923. 
Morris, T. “Army Officer's Report of Indian War and Treaties," Washington Historical Quarterly, 19 (1928), 134-141.

Morris, W. Gouverneur. Address Delivered Before the Society of California Volunteers. San Francisco: Commercial Steam Printing House, Francis, Valentine and Co., 1866.

Mossman, Isaac Van Dorsey. A Pony Expressman's Recollections. N.P.: Champoeg Press, 1955.

Mullan, Johan. "From Walla Walla to San Francisco,” Oregon Historical Quarterly, 4 (1903) 3, 202-226.

Murray, Keith, "Pig War Letters: A Romantic Account of the San Juan Crisis,” Columbia 1 (Fall) 1987, 11-20.

Nelson, Herbert and Onstad, Preston, editors. A Webfoot Volunteer: The Diary of William M. Hilleary, 1864-1866. Corvallis, OR: Oregon State University Press, 1965.

Newmark, Harris. Sixty Years in Southern California, 1853-1913, edited by Maurice and Marco R. Newmark . Boston and New York: Houghton Mifflin Company, 1930.

Nunis, Doyce B. Jr., editor. The Golden Frontier: The Recollections of Herman Francis Reinhart, 1851-1869. Austin, TX: University of Texas Press, 1962.

Ord, Edward O.C. Ord’s Diary in Curry County, Oregon 1856. n.p. 1970.

Orton, Richard, compiler. Records of California Men in the War of the Rebellion, 18611867. Sacramento, CA: State Printing Office, 1890.

Pambrun, Andrew Dominique. Sixty Years on the Frontier in the Pacific Northwest. Fairfield, WA: Ye Galleon Press, 1978.

Patterson, Edna B., editor. “The Diary of Joe F. Triplett,” Nevada Historical Quarterly, 2 (1959) 2, 1-14.

Pettis, George H. "Frontier Service During the Rebellion, or a History of Company K, First Infantry, California Volunteers," Military Order of the Loyal Legion of the United States, Soldiers and Sailors Historical Society of Rhode Island. Providence, RI: Historical Society of Rhode Island, 1885.

Pickering, William. “Washington’s War Governor,” Washington Historical Quarterly, 8, (April 1917), 2, 91-95.

Pickett, John T. "Letter From Colonel John T. Pickett, of the Southern Confederacy, to Senor Don Manuel Zamacona, Minster of Foreign Affairs, Mexico,” introduction by Mary Wilhelmine Williams, Hispanic American Historical Review 2 (1919), 611-617. 
Pratt, Harry E. “22 Letters of David Logan, Pioneer Oregon Lawyer,” Oregon Historical Quarterly, 44 (1943), 3, 253-285.

Prosch, Charles. Reminiscences of Washington Territory. Fairfield, WA: Ye Galleon Press, 1969.

Romero, Matis. A Mexican View of America in the 1860s: A Foreign Diplomat Describes the Civil War and Reconstruction, edited and translated by Thomas Schoonover. Rutherford, Madison, and Teaneck: Farleigh Dickinson University Press, 1991.

Sager, Catherine, Elizabeth, and Matilda. The Whitman Massacre of 1847. Fairfiled, WA: Ye Galleon Press, 1986.

Saunders, Mary. The Whitman Massacre. Fairfiled, WA: Ye Galleon Press, 1977.

Schneirson, Eric, editor. The Private Letters of Captain Hall: An Epic of an Argonaut in the California Gold Rush, Oregon Territories, Civil War, and Oil City. Glendale, CA: London Book Company, 1974.

Schreier, Konrad F., editor. “The California Column in the Civil War: [Eli W.] Hazen's Civil War Diary,” Journal of San Diego History, 22 (1976) 2, 31-48.

Scott, Charles L. The Adventures of Charles L. Scott, Esq. n.p.: Monroe County Heritage Museum, 1996.

Sheridan, Philip H. Personal Memoirs of P.H. Sheridan, two volumes. New York:

Charles L. Webster and Company, 1888.

Shotwell, Thomas Phelps. The Indian Attack on Seattle, January 26, 1856. Seattle, WA: Farwest Lithograph and Printing Company, 1932.

Smith, John E. “A Pioneer of the Spokane Country,” Washington Historical Quarterly, 7 (October 1916) 4, 267-277.

Stanley, George F. Mapping the Frontier: Charles Wilson's Diary of the Survey of the $49^{\text {th }}$ Parallel, 1858-1862, While Secretary of the British Boundary Commission. Seattle: University of Washington Press, 1970.

Sweeney, James. “Narrative,” Washington Historical Quarterly, 12, (July 1921) 3, 202210.

"Tamarac”. "A Lost History: Experiences of Co. A, 2d Cal. Cav., Not Recorded Officially,” National Tribune, March 26, 1896 and April 2, 1896. 
Tanasoca, Steven and Sudduth, Susan, editors. "A Journal Kept by George A. Harding,” Oregon Historical Quarterly 79 (Summer 1978) 2, 172-202.

Thompson, DeWitt, C. "California in the Rebellion," Military Order of the Loyal Legion of the United States, Civil War Papers of the California Commandery and Oregon Commandery. Wilmington, N.C.: Broadfoot Publishing, 1995.

Thompson, Jerry, editor. Texas and New Mexico on the Eve of the Civil War: The Mansfield and Johnston Inspections, 1859-1861. Albuquerque, NM: University of New Mexico Press, 2001.

United States Government. Condition of the Indian Tribes: Report of the Joint Special Committee, Appointed Under Joint Resolution of March 3, 1865 With an Appendix. Millwood, New York: Kraus Reprint, 1973.

. Preliminary Report on The Eighth Census, 1860. Washington D.C., Government Printing Office, 1862.

United States War Office. The War of the Rebellion: Official Records of the Union and Confederate Armies. Washington D.C.: U.S. Government Printing Office, 1897.

Walker, Henry P., editor. "Soldier in the California Column: The Diary of John W. Teal,” Arizona and the West, 13 (1971), 33-82.

Wetteman, Robert P., Jr. "A Virginia Soldier in the Frontier Army: The Letters of Sergeant John R. Whaley, Second U.S. Artillery, 1854-1859," Military History of the West, 29 (1999) 1, 63-88.

Whitworth, George, F. "Retrospective of Half a Century,” Washington Historical Quarterly, 1 (July 1907) 4, 197-208.

White, Katherine A., compiler. A Yankee Trader in the Gold Rush: The Letters of Franklin A. Buck. Boston and New York: Houghton Mifflin Company, 1930.

Wight, Willard, editor. “Civil War Letters of John Young Lind,” Journal of the Presbyterian Historical Society, 39 (1961) 2, 76-87.

Wistar, Isaac J. Autobiography of Isaac Jones Wistar, 1827-1905. Philadelphia: The Wistar Institute of Anatomy and Biology.

Wolcott, Marjorie Tisdale, editor. Pioneer Notes from the Diaries of Judge Benjamin Hayes, 1849-1875. New York: Arno Press, 1976.

Woody, Frank H. "From Missoula to Walla Walla in 1857, on Horseback," Washington Historical Quarterly, 3 (October 1912) 4, 277-286. 


\section{SECONDARY SOURCES}

\section{THESIS AND DISSERTATIONS}

Bastin, Donald E., "Rebels at the Gate: Civil War San Francisco and the Confederate Sea-Borne Threat,” Master’s Thesis, California State University, Hayward, 2001.

Blackburn, Charles B., "Military Opposition to the Official State Department Policy Concerning the Mexican Intervention, 1862-1867,” Ph.D. Dissertation, Ball State University, 1969.

Britton, Jesse Duane, "Bureaucrats, Miners, and the Nez Perce Indians: Treaty-making in Washington Territory During the Civil War,” Ph.D. Dissertation, Washington State University, 1988.

Dodson, Edwin Stanton, “A History of Nevada During the Civil War,” Master’s Thesis, University of Oregon, 1947.

Dunham, Mabel Elizabeth, “Attempts of Southern Sympathizers to Gain Control of California,” Master’s Thesis, Southwest Texas State Teachers College, 1939.

Edwards, Glenn Thomas, Jr., “Oregon Regiments in the Civil War Years: Duty on the Indian Frontier,” Master’s Thesis, University of Oregon, 1960.

, “The Department of the Pacific in the Civil War,” Ph.D. Dissertation, University of Oregon, 1963.

Ehrlich, Walter, "Military Operations of the Civil War in Arizona and New Mexico, 1861-1865,” Master’s Thesis, Washington University, 1947.

Fiedler, Bruce M., “The Mexican Connection: Confederate and Union Diplomacy on the Rio Grande, 1861-1865,” Master’s Thesis, North Texas State University, 1978.

Forte, David George, “Civil War Activities in the Northwest,” Master’s Thesis, Central Washington University, 1979.

Hageman, Todd. “Lincoln and Oregon,” Master’s Thesis, Eastern Illinois University, 1988.

Hansen, David Kimball, "Public Response to the Civil War in Washington Territory and Oregon, 1861-1865,” Master’s Thesis, University of Washington, 1971.

Herbner, Lloyd Wayne, “The Military Establishments in Southern California During the Civil War,” Master’s Thesis, Claremont Graduate School, 1952. 
Hockemeyer, Karen Sue, “The Southern Minority? -The Strength of the Confederate and the Copperhead Sentiment in Santa Clara County, California, 1860-1865,” Master’s Thesis, San Jose State University, 1987.

Hurt, Edward Jr., “The Confederate Interest in the Maximilian Affair,” Master's Thesis, University of Oklahoma, 1939.

Jolivette, Tristan Edward, “Continuing the Cause: Union Soldier Reenlistments of 1864,” Master’s Thesis, California State University, Fullerton, 1999.

McLarney, Donald F. “The American Civil War in Victoria, Vancouver Island Colony,” A Paper presented to Highline Community College, 1972.

Mott, Marguerite, “Activities in the Northwest, 1848-1861, Under the Direction of the United States War Department,” Master’s Thesis, Washington University, 1932.

O’Gorman, J. Tim. “The Pig War,” Master’s Thesis, University of Idaho, 1980.

Payne, William Kenneth, "How Oregonians Learned About the Civil War: The War Between the States as Reported in the Oregon Press, 1861-1865,” Master's Thesis, University of Oregon, 1963.

Salazar, Anthony Raymond, "The Role of the American Civil War in French Intervention in Mexico and its Impact on Relations with Mexico, 1861-1867,” Master's Thesis, University of Oregon, 1991.

Spalding, Imogene, “The Attitude of California to the Civil War,” Master’s Thesis, University of Southern California, 1912.

Talbott, Laurence Fletcher. "California Secessionist Support of the Southern Confederacy: The Struggle 1861-1865,” Ph.D. Dissertation, The Union Institute, 1995.

Thomas, Gary E. "Military Operations Against the Indians in the Humboldt Military District, 1861-1865,” Paper submitted to History Department, Humboldt State University, 1963.

Van Winkle, Roger A. “A Crisis in Obscurity: A Study of Pro-Southern Activities in Oregon, 1854-1865,” Master’s Thesis, Western Washington University, 1968.

\section{BOOKS AND ARTICLES}

Adams, George Rollie. General William S. Harney: Prince of Dragoons. Lincoln, NE and London: University of Nebraska Press, 2001. 
Apostol, Jane. “An Army Bride Goes West,” Southern California History, 72 (1990) 4, 303-320.

Baker, Marcus. "Survey of the Northwestern Boundary of the United States, 18571861,” Bulletin of the United States Geological Survey, 174 (1900), 9-71.

Beales, Benjamin Bronston. “The San Jose Mercury and the Civil War,” California Historical Quarterly, 22 (1943) 355-364.

Beckham Stephen Dow. “Lonley Outpost: The Army’s Fort Umpqua,” Oregon Historical Quarterly, 70 (1969) 3, 233-257.

Bergeron, Paul H. The Presidency of James K. Polk. Lawrence, KS: University Press of Kansas, 1987.

Berwanger, Eugene H. The British Foreign Service and the American Civil War. Lexington, KY: University Press of Kentucky, 1994.

Blackett, R.J.M. Divided Hearts: Britain and the American Civil War. Baton Rouge, LA: Louisiana State University Press, 2001.

Blumber, Arnold. The Diplomacy of the Mexican Empire, 1863-1867. Malabar, FL: Robert E. Krieger Publishing Company, 1987 paperback edition.

Bridges, C.A. “The Knights of the Golden Circle: A Filibustering Fantasy,” Southwest Historical Quarterly, 44 (1941) 3, 287-302.

Brown, Dee Alexander. The Galvanized Yankees. Lincoln, NE and London: University of Nebraska Press, 1986 paperback edition.

Brown, Russell K. "An Old Woman with a Broomstick: General David E. Twiggs and the U.S. Surrender in Texas, 1861,” Military Affairs, 48 (1984) 2, 57-61.

Burns, Robert Ignatius. The Jesuits and the Indian Wars of the Northwest. New Haven, CT and London: Yale University Press, 1966.

Butler, Anne M. “Military Myopia: Prostitution on the Frontier,” Prologue, 13 (1981) 4, 233-250.

Callahan, James Morton. Evolution of Seward's Mexican Policy. Morgantown, WV, 1908.

Carson, James F. “California: Gold to Help Finance the War,” Journal of the West, 14 (January 1975) 1, 25-41.

Case, Lynn M. and Spencer, Warren F. The United States and France: Civil War Diplomacy. Philadelphia: University of Pennsylvania Press, 1970. 
Chandler, Robert J. "The Velvet Glove: The Army During the Secession Crisis in California, 1860-1861,” Journal of the West, 20 (1981) 4, 35-42.

. “California’s 1863 Loyalty Oaths Another Look,” Arizona and the West, 21 (1979) 3, 215-234.

Chappel, Jill. "Settlement Continuity between Pioneer and Post-Frontier Periods in Oregon’s Willamette Valley,” Pioneer America Society Transactions, 16 (1993), 1-12.

Chaput, Donald. “The Civil War Military Post on Catalina Island,” Southern California Quarterly, 75 (YEAR) 1, 37-50.

Clark, George T. Leland Stanford: War Governor of California Railroad Builder and Founder of Stanford University. Palo Alto, CA: Stanford University Press, 1931.

Clendenen, Clarence C. "A Confederate Spy in California: A Curious Incident of the Civil War,” Southern California Quarterly, 45 (September 1963), 3, 219-233.

. "Dan Showalter - A California Secessionist,” California Historical Society Quarterly, 40 (1962) 4, 309-325.

• "Expedition that Never Sailed,” California Historical Society Quarterly, 34 (1955) 2, 149-156.

Cleveland, Alfred A. "Social and Economic History of Astoria," Oregon Historical Quarterly 4 (1903) 2, 130-150.

Colton, Roy. The Civil War in Western Territories: Arizona, Colorado, New Mexico, and Utah. Norman, OK: University of Oklahoma Press, 1959.

Cooney, Percival J. "Southern California in the Civil War,” Historical Society of Southern California, 13 (1924) 1, 54-68.

Davison, Stanley R., and Tash, Dale. “Confederate Backwash in Montana,” Montana, 17 (1967) 4, 50-58.

Doyle, Julie A., Smith, John David. “ "The very best soldiers in the world:” Two Surgeons Examine California’s Civil War Recruits,” Military History of the West, 27 (1997) 1, 59-82.

Dunn, J.P., Jr. Massacres of the Mountains: A History of the Indian Wars of the Far West, 1815-1875. New York: Archer House, Inc., 1958.

Dustin, Charles Mial. "The Knights of the Golden Circle: The Story of the Pacific Coast Secessionists,” Pacific Monthly, November 1911, 495-504. 
Dyer, Brainerd. “California’s Civil War Claims,” Southern California Quarterly, 45 (1963) 1, 1-24.

Edwards, G. Thomas. "Benjamin Stark, The U.S. Senate, and 1862 Membership Issues, Pt.I,” Oregon Historical Quarterly, 72 (Winter 1971) 4, 315-338.

. "Holding the Far West for the Union: The Army in 1861," Civil War History, 14 (1968) 4, 307-324.

. "Six Oregon Leaders and the Far-Reaching Impact of America’s Civil War," Oregon Historical Quarterly, 100 (Spring 1999) 1, 4-31.

Edwards, Malcolm. “The War of Complexional Distinction: Blacks in Gold Rush California \& British Columbia,” California Historical Quarterly, 56 (1977) 1, 34-56.

Ellison, Joseph. “Designs for a Pacific Republic, 1843-62,” Oregon Historical Quarterly, 31 (1930) 4, 321-342.

Farr, James. “Not Exactly a Hero,” California History, ?? (June 1986), 104-113.

Ferris, Norman B. Desperate Diplomacy: William H. Seward's Foreign Policy, 1861. Knoxville, TN: University of Tennessee Press, 1976.

Fendall, Lon W. "Medorem Crawford and the Protective Corps,” Oregon Historical Quarterly, 72 (1973) 1, 55-77.

Finch, L. Boyd. “Arizona in Exile: Confederate Schemes to Recapture the Far Southwest,” Journal of Arizona History, 33 (1992) 1, 57-84.

- Confederate Pathway to the Pacific: Major Sherod Hunter and Arizona Territory. Tucson: The Arizona Historical Society 1996.

Fischer, LeRoy H. “The Western States in the Civil War,” Journal of the West, 14 (January 1975) 1, 1-4.

Fisher, James A. “The Struggle for Negro Testimony, 1851-1863,” Southern California Quarterly, 51 (1969) 4, 313-324.

Frazer, Robert W. Forts of the West. Norman, OK: University of Oklahoma Press, 1972.

Freshour, Sidney Glenn. The Santa Cruz Cavalry Co. and the Butler Guard, 1861-1868. San Jose: Glenhaven Press, 1993. 
Fuller, Francis V. “The First Oregon Cavalry,” Oregon Historical Quarterly, 3 (June 1902), 124-163.

Gamboa, Erasmo. "Supply Line to the New Frontier,”, Columbia, 8 (1994) 4, 21-28.

Generous, Tom. "Over the River Jordan; California Volunteers in Utah During the Civil War,” California History, 63 (Summer 1984) 3, 200-211.

Gilbert, Benjamin. "Kentucky Privateers in California,” Register of Kentucky State Historical Society, -- (1940) --, 256-266.

. "Rumours of Confederate Privateers Operating in Victoria, Vancouver Island," British Columbia Historical Quarterly, 18 (YEAR) 3 and 4, 239-254.

Goldberg, Mitchell S. "Naval Operations of the United States Pacific Squadron in 1861,” The American Neptune, 33 (1973) 1, 41-48 and 49-51.

Goldman, Henry H. "Southern Sympathy in Southern California, 1860-1865," Journal of the West, 4 (1965) 4, 577-586.

Grenier, Judson A. "Colonel Jack Watson: Copperhead Assemblyman in Civil War California,” The Californians, 12 (1995) 5, 14-35.

Hall, Martin Hardwick. Sibley’s New Mexico Campaign. Austin, TX: University of Texas Press, 1960.

Hittell, John S. A History of the City of San Francisco. San Francisco: A.L. Bancroft and Company, 1878.

Holbrook, Francis X. "To Strike a Blow at the California Trade,” The American Neptune, 32 (1972) 3, 195-210.

Hoop, Oscar Winslow. "History of Fort Hoskins, 1856-65,” Oregon Historical Quarterly, 30 (1929) 4, 346-361.

Hopper, Sidney Glenn. Indian Wars in the Old Pacific Northwest. Burnby, British Columbia: Artarmon Publishing, 1996.

Hosler, Joseph. “Los Angeles’ Drum Barracks,” Civil War Times Illustrated, 30 (1991) 4, 18-20, 82.

Howard, Helen A. “Unique History of Fort Tejon,” Journal of the West, 18 (1979) 1, 4151.

Hull, Dorothy. "The Movement in Oregon for the Establishment of a Pacific Coast Republic,” Oregon Historical Quarterly, 15 (1916) 3, 177-200. 
Hunsaker, William J. “Lansford W. Hastings' Project for the Invasion and Conquest of Arizona and New Mexico for the Southern Confederacy,” The Arizona Historical Review, 4 (1931) 2, 5-12.

Hunt, Aurora. The Army of the Pacific, 1860-1866. Glendale, CA: The Arthur H. Clark Compnay, 1951.

Johannsen, Robert W. Frontier Politics and the Sectional Conflict: The Pacific

Northwest on the Eve of the Civil War. Seattle: University of Washington Press, 1955.

. "Spectators of Disunion: The Pacific Northwest and the Civil War," Pacific Northwest Quarterly, 44 (1959 [??]) 3, 106-114.

Johnson, Sidona, compiler. A Short History of Oregon. Chicago: A.C. McClurg and Company, 1904.

Josephy, Alvin, Jr. The Civil War in the American West. New York: Alfred A. Knopf, 1991.

. The Nez Perce Indians and the Opening of the Northwest. Boston and New York: Mariner Books, 1997 paperback edition.

Kennedy, Philip W. "Union and Confederate Relations in Mexico,” Duquesne Review 1 (1966), 47-63.

Kenny, Judith Keyes. "Founding of Camp Watson,” Oregon Historical Quarterly, 58 (1957) 1, 5-18.

Keshen, Jeff. “Cloak and Dagger: Canada West’s Secret Police, 1864-1867,” Ontario History, 79 (1987) 4, 353-381.

Kibby, Leo P. California, the Civil War, and the Indian Problem. Los Angeles: Lorrin L. Morrison and Carroll Spear Morrison Publishers, 1967.

Kirsch, Robert and Murphy, William. West of the West. New York: E.P. Dutton and Company, Inc., 1967.

Knuth, Priscilla. “"Picturesque’ Frontier: The Army’s Fort Dalles,” Oregon Historical Quarterly, 67 (1966) 3 and 4, 5-53 and 292-333.

Kornweibel, Theodore, Jr. "The Occupation of Santa Catalina Island During the Civil War,” California Historical Society Quarterly, 46 (1967) 4, 345-357.

LaLande, Jeff. “'Dixie’ of the Pacific Northwest: Southern Oregon's Civil War,” Oregon Historical Quarterly,100 (Spring 1999) 1, 32-81. 
Landes, Cheryl. “The San Juan Island Pig War,” Canadian West, 10 (Summer 1994), 16-18.

Lang, William L. Confederacy of Ambition: William Winlock Miller and the Making of Washington Territory. Seattle and London: University of Washington Press, 1996.

Lewis, Oscar. The War in the Far West, 1861-1865. New York: Doubleday and Company, Inc. 1961.

Lewis, William S. "The First Militia Companies in Eastern Washington Territory," Washington Historical Quarterly, 11 (October 1920) 4, 243-249.

Limerick, Patricia Nelson. Legacy of Conquest. New York and London: W.W. Norton, 1987.

Something in the Soil: Legacies and Reckoning in the New West. New York and London: W.W. Norton and Company, 2000.

Long, E.B. "War Beyond the River - Our Civil War and the Uncivil West,” Denver Westerners Roundup, 30 (June 1974) 5, 3-25.

Lutz, John. "Inventing an Indian War: Canadian Indians and American Settlers in the Pacific Northwest, 1854-1864,” Journal of the West, 38 (July 1998) 3, 7-13.

MacPherson, Helen G. Canadian Public Opinion on the American Civil War. New York: Octagon Books, 1974.

Mahoney, Harry Thayer and Mahoney, Marjorie Locke. Mexico and the Confederacy, 1860-1867. San Francisco, London, Bethesda, MD: Austion and Winfield Publishers, 1998.

Manring, Benjamin. Conquest of the Couer D’Alenes, Spokanes, \& Palouses. Fairfield, WA: Ye Galleon Press, 1975.

Masich, Andrew, E. The Civil War in Arizona: The Story of The California Volunteers, 1861-1865. Norman, OK: University of Oklahoma Press, 2006.

Mason, Edwin C. “How We Won the San Juan Archipelago,” Minnesota Historical Society Collections, 9 (1913), 34-54.

McCabe, James O. The San Juan Water Boundary Question. Toronto: University of Toronto Press, 1964.

McGinnis, Ralph Y. and Smith, Calvin N., editors. Abraham Lincoln and the Western Territories. Chicago: Nelson-Hall Publishers, 1994. 
Mcginty, Brian. "I Will Call a Traitor a Traitor,” Civil War Times Illustrated, 20 (1981) 3, 24-31.

McGregor, Alexander C. "The Economic Impact of the Mullan Road on Walla Walla, 1860-1883,” Pacific Northwest Quarterly, 65 (1974) 3, 118-129.

McLean, James. California Sabers: The $2^{\text {nd }}$ Massachusetts Cavalry in the Civil War. Bloomington and Indianapolis, IN: Indiana University Press, 2000.

McPherson, James. Ordeal by Fire. New York, et. al: McGraw Hill, Inc., 1982.

Merk, Frederick. The Monroe Doctrine and American Expansionism, 1843-1849. New York: Vintage Books, 1966.

Merrill, Irving. "The Civil War in the West: The 1864 Trail Season,” Overland Journal, 9 (1992??) 4, 15-27.

Miller, Robert R. Arms Across the Border: United States Aid to Juarez During the French Intervention in Mexico. Philadelphia: The American Philosophical Society, 1973. $\overline{193-214}$ . “Californians Against the Emperor,” California Historical Quarterly, 37 (1958), . "Lew Wallace and the French Intervention in Mexico," Indiana Magazine of History, 54 (1963), 31-50.

Moomaw, Juliana P. "Oregon: Patroling the New Northwest," Journal of the West, 14, (January 1974) 1, 5-24.

Morrison, Michael A. Slavery and the American West. Chapel Hill, NC and London: University of North Carolina Press, 1997.

Mozer, Corinne C. “A Brief History of Fort Fillmore, 1851-1862,” El Palacio, 74 (1967) 2, 5-18.

Murphy, Lawrence R. "The Enemy Among Us: Venereal Disease Among Union Soldiers in the Far West, 1861-1865,” Civil War History, 31 (1985) 3, 257-269.

Murray, Keith A. The Pig War. Tacoma, WA: Washington State Historical Society, 1968.

Muscatine, Doris. Old San Francisco. New York: G.P. Putnam’s Sons, 1975. 
Nasatir, A.P. “ The French Attitude in California During the Civil War Decade,” California Historical Society Quarterly, 43 (1964) 1, 19-35.

Onstad, Preston E. “Camp Henderson,” Oregon Historical Quarterly, 65 (1964) 3, 297302.

. “Fort on the Luckiamute: A Resurvey of Fort Hoskins,” Oregon Historical Quarterly, 65 (1964) 2, 173-196.

Parson, Thomas E. Bear Flag and Bay State in the Civil War: The Californians of the Second Massachusetts Cavalry. Jefferson, NC and London: McFarland and Company, Inc. 2001.

Pekar, M.A., and Mingus, Edna, compilers. Oregon Soldiers During the Civil War. Portland, OR: Genealogical Forum of Portland, Inc. 1961.

Peterson, Richard. “Thomas Starr King in California, 1860-64: Forgotten Naturalist of Civil War,” California History, 69 (1990) 1, 12-21.

Perko, Richard. "A Forgotten Passage to Puget Sound: The Fort Steilacoom-Walla Walla Road,” Montana: The Magazine of Western History, 35 (1985) 1, 38-47.

Peterson, Richard. "Thomas Starr King in California, 1860-64: Forgotten Naturalist of the Civil War Years,” California History, 69 (1990) 1, 12-21.

Pletcher, David. The Diplomacy of Annexation. Columbia, MO: University of Missouri Press, 1973.

Pompey, Sherman Lee. A History of the First Battalion of California Mountaineers in the Civil War. Independence, CA: Genealogical Publishing Company.

David M. Potter. The Impending Crisis 1848-1861. New York, Philadelphia, London: Harper Torchbooks, 1993.

Prezelski, Tom. "Lives of the Californio Lancers: The First Battalion of Native California Cavalry, 1863-1866,” Journal of Arizona and the West, 40 (1999) 1, 29-52.

Prosch, Thomas W. “The United States Army in Washington Territory,” Washington Historical Quarterly, 2 (October 1907) 1, 28-32.

. “Oregon in 1863,” Oregon Historical Quarterly, 14 (1913) 1, 61-64.

. “The Indian War in Washington Territory,” Oregon Historical Quarterly, 16

(March 1915) 1, 1-23. 
. "Washington Territory Fifty Years Ago,” Washington Historical Quarterly, 4 (April 1913) 2, 96-104.

Prucha, Francis P. American Indian Treaties. Berkley, Los Angeles, London:

University of California Press, 1994.

Richter, Betina. Fort Miller, California, 1851-1865. New York, Frankfurt, Bern, Paris: Peter Lang, 1988.

Rickey, Don Jr. Forty Miles a Day on Beans and Hay. Norman, OK: University of Oklahoma Press, 1983 paperback edition.

Riegel, Robert E. and Athearn, Robert G. America Moves West. New York, Chicago, San Francisco, Toronto, and London: Holt, Rinehart and Winston, Inc., 1966.

Robbins, William G. "Social and Economic Change in Roseburg, Oregon, 1850-1885:

A Quantitative View,” Pacific Northwest Quarterly, 64 (197??) 2, 80-87.

Robinson, William M. Jr. The Confederate Privateers. New Haven, CT: Yale University Press, 1928.

Ruby, Robert H. and Brown, John A. The Cayuse Indians: Imperial Tribesmen of Old Oregon. Norman, OK: University of Oklahoma Press, 1972.

Rutherford, Phillip R. “Texas Leaves the Union,” Civil War Times Illustrated, 20 (1981) 3, 13-23.

Sage, Walter. Sir James Douglas and British Columbia. Toronto: University of Toronto Press, 1930.

Scammell, J.M. “Military Unites in Southern California, 1853-1862,” California Historical Quarterly, 29 (1950), 229-249.

Schlike, Carl P. "Massacre on the Oregon Trail in the Year 1860,” Columbia, 1 (1987) 1, 33-44.

- General George Wright: Guardian of the Pacific Coast. Norman, OK and London: University of Oklahoma Press, 1988.

Sebring, F.M. “The Indian Raid on the Cascades in March 1856," Washington Historical Quarterly, 19 (April 1928) 2, 99-107.

Shaw, William Lawrence. The Impact of Napoleon III Upon the Pacific Coast. Sacramento, CA: California Civil War Centennial Commission, n.d. 
Shorre, Toni Rysdam-, Gerrit .... A Dutchman in Oregon. Bend, OR: South Forty Publications, 1985.

Shutes, Milton H. Lincoln and California. Palo Alto, CA: Stanford University Press, 1967.

Smart, Charles Allen. Viva Juarez ! Westport, CT : Greenwood Press, Publishers, 1975.

Smith, Philip Dodd, Jr. “The Sagebrush Soldiers,” Nevada Historical Society Quarterly, 5 (1962) 3\&4, 1-84.

Smits, Dan D. “'Fighting Fire with Fire:” The Frontier Army’s Use of Indian Scouts and Allies in the Trans-Mississippi Campaigns, 1860-1890," American Indian Culture and Research Journal, 22 (1998) 1, 73-116.

Spring, Agnes Wright. Caspar Collins: The Life and Exploits of an Indian Fighter of the Sixties. Lincoln, NE: University of Nebraska Press, 1969.

Stacey, C.P. Canada and the British Army, 1846-1871. Toronto: University of Toronto Press, 1963.

Stanley, Gerald. "Civil War Politics in California,” Southern California Quarterly, 64 (1982) 2, 115-132.

Strobridge, William F. Regulars in the Redwoods: The U.S. Army in Northern California 1852-1861. Spokane, WA: Arthur H. Clark Company, 1994.

Tannatt, Elizabeth F., compiler. Indian Battles in the Inland Empire in 1858. Spokane, WA, 1914.

Taylor, Quintard. "The Emergence of Black Communities in the Pacific Northwest: 1865-1910,” Journal of Negro History, 54, (YEAR) 4, 342-354.

Throckmorton, Arthur L. "The Role of the Merchant on the Oregon Frontier: The Early Business Career of Henry W. Corbett, 1851-1869,” Journal of Economic History, 16, (1956) 4, 539-550.

Trafzer, Clifford E. and Scheuerman, Richard D. Renegade Tribe: The Palouse Indians and the Invasion of the Inland Pacific Northwest. Pullman, WA: Washington State University Press, 1986.

Trimble, Will J. "A Soldier of the Oregon Frontier," Oregon Historical Quarterly, 8 (1907) 1, 42-50.

Tyler, S. Lyman. "Ute Indians along Civil War Communication Lines,” Utah Historical Quarterly, 46, (Summer 1978) 3, 251-261. 
Utley, Robert M. Frontiersmen in Blue: The United States Army and the Indian, 18481865. New York: Macmillan Publishing Co., 1967.

. Frontier Regulars: The United States Army and the Indian, 1860-1891. New

York: Macmillan Publishing Co., Inc., 1973.

. The Indian Frontier of the American West 1846-1890. Albuquerque: University of New Mexico Press, 1987.

Vouri, Michael. The Pig War: Standoff at Griffin Bay. Friday Harbor, WA: Griffin Bay Bookstore, 1999.

Waitman, Leonard B. “The Knights of the Golden Circle,” San Bernardino County Museum Association Quarterly, 15 (Summer 1968) 4, 1-37.

Wang, Peter Heywood. “The Mythical Confederate Plot in Southern California," San Bernardino County Museum Association Quarterly, 16, (Summer 1969) 4, 1-16.

Warner, Ezra J. Generals in Gray: Lives of the Confederate Commanders. Baton Rouge, LA and London: Louisiana State University Press, 1959.

. Generals in Blue: Lives of the Union Commanders. Baton Rouge, LA and London: Louisiana State University Press, 1964.

Wayne, Michael. "The Black Population of Canada West on the Eve of the American Civil War: A Reassessment Based on the Manuscript Census of 1861, Social History, 28 (1995), 465-485.

Wells, Donald N. "Farmers Forgotten: Nez Perce Suppliers of the North Idaho Gold Rush Days,” Idaho Yesterdays 2 (1958), 28-32.

White, Loring. "Frontier Patrol: The Army and the Indians in Northeastern California, 1861,” Journal of the Shaw Historical Library, 9 (1995), 45-64.

Wiel, Samuel C. Lincoln's Crisis in the Far West. San Francisco, privately printed, 1949.

Winans, W.P. “Fort Colville, 1859-1869,” Washington Historical Quarterly, 3 (October 1908) $1,78-82$.

Winks, Robin W. “The British North American West and the Civil War,” North Dakota History, 24 (1957) 139-152.

Canada and the United States The Civil War Years. Baltimore: the Johns Hopkins Press, 1960. 
"Rumors of Confederate Privateers Operating in Victoria, Vancouver Island,"

British Columbia Historical Quarterly, 18 (1954) 3-4, 239-255.

Woodward, Walter Carleton. The Rise and Early History of Political Parties in Oregon, 1843-1868. Portland, OR: The J.K. Gill Company, 1913.

Woolsey, Ronald C. "Disunion or Dissent? A New Look at an Old Problem in Southern California Attitudes Toward the Civil War,” Southern California Quarterly, 66 (1984) 3, 185-205. 